\title{
MADERA, HORMIGÓN, COMPOSICIÓN Y SISTEMA
}

La obra de Mario Soto y Raúl Rivarola en Misiones

(1956-1963)

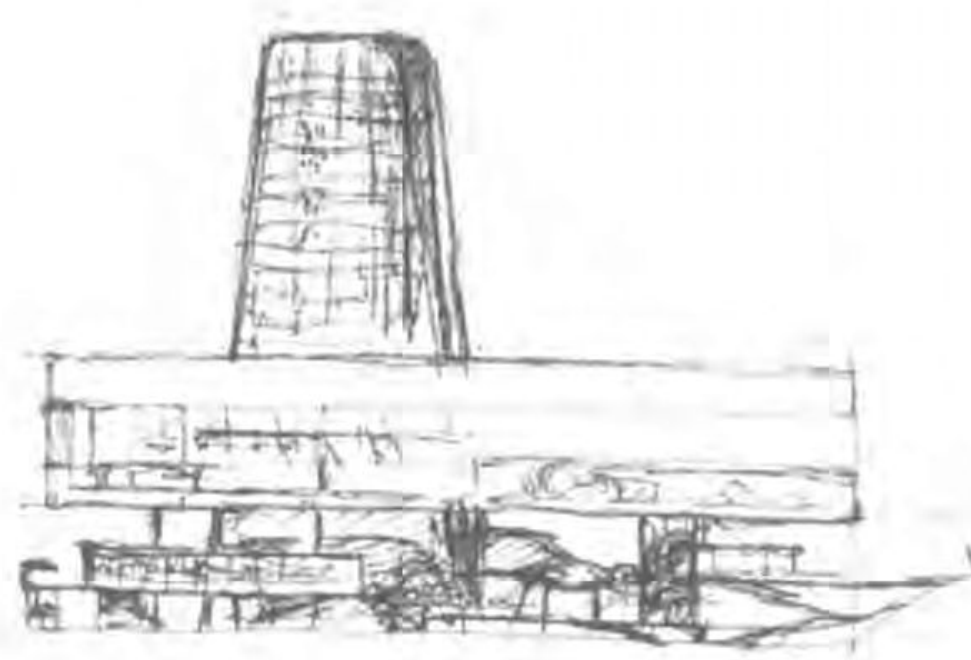

MAESTRÍA en Historia y Cultura de la Arquitectura y la Ciudad Universidad Torcuato Di Tella

Escuela de arquitectura y estudios urbanos 


\author{
Universidad Torcuato Di Tella \\ Escuela de Arquitectura y Estudios Urbanos \\ Maestría en Historia y Cultura de la Arquitectura y la Ciudad
}

MADERA, HORMIGÓN, COMPOSICIÓN y SISTEMA

La obra de Mario Soto y Raúl Rivarola en Misiones

(1956-1963)

Autor: Christian Noetzly

Director: Claudia Shmidt

Firma del director

Fecha de entrega: Junio de 2016 


\section{Universidad Torcuato Di Tella}

Rector: Ernesto Schargrodsky

Vicerrectora: Catalina Smulovitz

Escuela de Arquitectura y Estudios Urbanos

Decano: Ciro Najle

Carrera de Grado de Arquitectura

Director: Sergio Forster

Maestría en Historia y Cultura de la Arquitectura y la Ciudad Director: Julián Varas

Programa en Arquitectura y Tecnología

Coordinador: Francisco Cadau

Programa en Arquitectura del Paisaje

Coordinador: Juan Pablo Porta

Programa en Preservación y Conservación del Patrimonio Coordinador: Fabio Grementieri

Maestría en Economía Urbana (c/Escuela de Gobierno)

Directora: Cynthia Goytia

Centro de Estudios de Arquitectura Contemporánea

Coordinador: Julián Varas 


\section{Resumen}

La arquitectura proyectada por Mario Soto y Raúl Rivarola, en la provincia de Misiones, se recorta contra la provincialización de los territorios nacionales, la vinculación entre Estado y arquitectura; el entrecruzamiento entre técnica y política; el proceso de "invención de las tradiciones", la "cuestión nacional", el dilema de los estilos y el debate por la elección de los espacios cívicos representativos para la expresión de los "lenguajes nacionales". Es posible estudiar, a través de su obra, las múltiples discusiones que tensaban la disciplina, atravesada por las transformaciones políticas, económicas y culturales. El escenario geopolítico nacional, producido por la formación de nuevas provincias, en concomitancia con un mundo que se reconstruía luego de la segunda posguerra, introdujo nuevos temas y necesidades. La arquitectura debía brindar respuestas a las demandas de una sociedad que exigía incorporar a sus edificios, criterios de serialidad, indeterminación, flexibilidad y crecimiento ilimitado.

Una generación de arquitectos, surgida en los inicios de 1950, debió enfrentarse a los desafíos que este escenario les propuso. Motivando la reestructuración de su proceder disciplinar, puesto en tensión por una mirada que descubría una modernidad incipiente, confrontada por una formación atravesada por un academicismo debilitado. Estableciéndose un espacio de transición, parafraseando a Banham, una "zona de silencio", en la que se sucedieron interesantes transformaciones.

Si una de las problemáticas de la década de 1950, es el pasaje de la grilla estructural a la resistencia por forma, la arquitectura de Soto y Rivarola, ofrece un claro ejemplo de este debate. El caso de las escuelas y las hosterías, oficia de prototipo de estructura resuelta a partir de una retícula de madera; mientras que la cubierta de la escuela en Leandro N Alem, aporta el modelo de estructura plástica construida en hormigón armado.

Se verifican múltiples cambios en la reflexión disciplinar y en el modo de concebir el proyecto. Variados temas jalonan la práctica profesional: el pasaje de un pensamiento bidimensional a uno tridimensional en la concepción de edificios. La disolución del imperativo: programa y forma. La aparición de una arquitectura de partes funcionales ensambladas, vinculadas a partir de ejes materializados por las circulaciones. La supervivencia de los conceptos de "partido" y el repertorio "beaux arts" tamizados por nuevos requerimientos, permiten vislumbrar la problemática y contradicciones de los períodos de cambio.

Partido, Carácter, serialidad e indeterminación, pero también "Madera, Hormigón, Composición y Sistema" son los grandes temas que atravesaron la época y la arquitectura de Soto y Rivarola. Ellos brindaron ajustadas respuestas, conformándose en verdaderos intérpretes de las demandas que el momento exigía, produciendo una arquitectura de profunda modernidad, anclando permanencias vestigios y referencias, en un presente que necesita redescubrirlas.

Palabras clave: Mario Soto, Raúl Rivarola, provincialización de los Territorios Nacionales, arquitectura "beaux arts", "academicismo", "composición", partido, arquitectura de Sistemas, arquitectura de Estado, Plan Urbis, Misiones. 



\section{ÍNDICE}

Introducción

1

Crisis del sistema económico en los estados modernos

Transformaciones Geopolíticas

La provincialización de Misiones

Plan para la provincia de Misiones:

EI plan URBIS:

"Nothing succeeds as success"

Cuatro Escuelas de madera

Seis Hosterías de madera

Escuela Normal $N^{\circ} 1$ en Leandro N. Além

Instituto de Previsión Social de Posadas

Madera

Hormigón

Composición y Sistema

Epílogo

Créditos de imágenes e ilustraciones

Bibliografía 



\section{Agradecimientos}

Este trabajo es el resultado de un camino que se inició de forma difusa durante el curso de las materias de la Maestría en Historia y Cultura de la Arquitectura y la Ciudad, en la Universidad Torcuato Di Tella en el 2012, adquiriendo precisión y contornos más definidos a partir de las esclarecedoras charlas y comentarios mantenidos con los profesores de aquella casa de estudios. En tal sentido quisiera agradecer a todos los que con su saber, afecto y tiempo, colaboraron para construir esta tesis.

A Pancho Liernur, que motivó el acercamiento a las figuras de Mario Soto y Raúl Rivarola, haciéndome descubrir la dimensión de su arquitectura. A Luis Müller, por sus generosos aportes, incluso en material fotográfico de muchas de las obras que figuran en el anexo.

Pero muy especialmente a mi directora, Claudia Shmidt, que ha acompañado de manera constante e incondicional este proceso, poniendo a disposición todo su conocimiento y profesionalismo, sin reparar en días ni horarios. Entrevistas, interminables cadenas de mails, en las horas más disparatadas y extensas videoconferencias, dan cuenta de todo el apoyo brindado; pero esencialmente ocasionó y motivó que esta investigación excediera el marco de una catalogación de material de archivo y tomara otro vuelo y profundidad.

A los verdaderos protagonistas: Ios arquitectos Mario Soto, lamentablemente fallecido y fundamentalmente a Raúl Rivarola, que con su inmensa calidez me dio la posibilidad de realizar numerosas entrevistas, plenas de datos y sabiduría y al mismo tiempo tener total acceso a su invalorable archivo profesional, que constituye el eje central, sobre el que se construyó la tesis.

A Myriam Goluboff, con quien he mantenido una asidua relación, mediada por larguísimas conversaciones, muchas de ellas telefónicas, que acortaron distancias entre España, su lugar de residencia y última patria de Mario y la Argentina, facilitándome además, gran cantidad del material que completa la información y la documentación de las obras.

Al profesor Nicolás Bares, amigos y compañeros de cátedra, que han soportado mi obsesión en incontables y monotemáticas conversaciones, más la posibilidad de testear los avances, introduciendo estos temas dentro de las clases regulares de la materia Arquitectura de la Universidad Nacional de La Plata.

A los pacientes "amigos" de la biblioteca de la FAU UNLP que facilitaron innumerable material y su indulgencia con los vencimientos, siempre superados, de libros surgidos de búsquedas inciertas. A Rosana Verón de la UTDT, por su pronta e invariable respuestas a mis múltiples requerimientos. Al personal y bibliotecarios de la UTDT y de la Sociedad Central de Arquitectos.

Estas tareas de investigación y estudio, demandan una combinación de tiempo y esfuerzo, no solo de quien las realiza, sino de todo el núcleo familiar que de manera anónima acompaña. En tal sentido deseo agradecer, muy especialmente, a Estela, mi madre, por su incondicional apoyo en todos los órdenes posibles, a mi hermano Alexis, también alcanzado por las reverberaciones de esta gesta.

A Máximo y Andrés, para ellos, todo. 



\section{Introducción}

Durante la década de 1950 se inicia un período central en el desarrollo y concreción de la obra pública en Argentina. La necesidad de reacomodar las economías nacionales, frente a las alteraciones del comercio internacional a causa de la inmediata posguerra, produjo en varios estados latinoamericanos la necesidad de encontrar los mecanismos que permitiesen incentivar el crecimiento de la industria y la generación de empleo.

El primer Plan Quinquenal (1947-1951), llevado adelante durante la inicial presidencia de Juan Domingo Perón (1946-1952), se superpuso sobre la reorganización de la administración pública, la nueva distribución de ministerios, la nacionalización de los servicios y la provincialización de los territorios nacionales. Todos estos factores se reflejaron de manera directa en la realización de un conjunto significativo de obras públicas.

La profundización de esta demanda no generó una reacción única y distintos grupos de arquitectos, muchos de ellos de reciente incorporación al terreno profesional, brindaron una multiplicidad de respuestas, interpretando cada uno de manera distinta, la arquitectura que mejor expresara "Io nacional", la presencia del Estado y "la modernidad"2.

1- HALPERÍN DONGHI, Tulio, et al.. Historia económica de América latina desde la independencia a nuestros días, Barcelona, Editorial Crítica

2- Para una mayor profundización de estos temas ver: SHMIDT Claudia (2012) “...mucho costó que la arquitectura "oficial” fuera moderna..." Revista Block, Número 9, 60 
Puede decirse que superada la instancia del "revival colonial" el "missión style" o el estilo californiano, de extendido uso en buena parte de las construcciones realizadas porla Fundación Eva Perón (1948-1955)³, el escenario, hacia mediados de la década de 1950 se propuso, cuando menos favorable, para la introducción y experimentación de nuevos desarrollos arquitectónicos, que iniciaron una práctica impregnada de gran apertura para encontrar la expresión que representara, el espíritu de un "Estado moderno".

El enfoque del rol de la arquitectura pública por parte de la administración nacional había sufrido un cambio sustancial en el contexto del advenimiento del gobierno peronista. A partir de entonces se pusieron en marcha ciertas políticas, orientadas a resolver la creciente demanda de vivienda social, que se sumaron a un importante plan de obras que incluyó la construcción de edificios educativos, centros turísticos, infraestructura vial y hospitalaria, fueron promovidos a partir de la puesta en marcha de los planes quinquenales, el llamado "Plan Carrillo" de salud, y la provincialización de los territorios nacionales. La obra proyectada y construida, de los arquitectos Mario Soto (1928-1982) y Raúl Rivarola (1928), atraviesa este particular momento y participa activamente de buena parte de los temas centrales de la década en materia de arquitectura y ciudad. Es posible identificar a través de ellas, aspectos de la vinculación entre Estado y arquitectura; el entrecruzamiento entre técnica y política; el proceso de "invención de las tradiciones"; la "cuestión nacional", la arquitectura de Estado 4 y las vanguardias, el dilema de los estilos más el debate por la elección de los espacios cívicos representativos que mejor expresaran los "lenguajes nacionales".

Estos temas fueron puestos en tensión por los criterios y metodologías empleados en la ideación del proyecto de arquitectura, en un momento en el que es posible encontrar cambios e innovaciones, pero al mismo tiempo constancias y persistencias, propias de las teorías "beaux arts", según las cuales, la idea de "partido" y "carácter" mantenían su importancia material y simbólica dentro del ejercicio disciplinar. El partido, dentro de la concepción académica, configuraba un posicionamiento ante el programa y su manifestación simbólica y representaba en algunos casos, el carácter que se esperaba y exigía a la arquitectura; en otros, la predeterminación de conceptos de síntesis y el procedimiento que conducía a la clara materialización de programas complejos que se exhibían mediante una incuestionable y adecuada expresión formal.

Ejes, geometría, formas puras, simetrías y equilibrio, conformaban una matriz propia del academicismo que se resistía a desparecer definitivamente del campo disciplinar y de la enseñanza de la arquitectura: el carácter arquitectónico y la aplicación del repertorio clásico subsistía durante la década de 1950 en la nueva Facultad de Arquitectura de la Universidad de Buenos Aires (FAU UBA) pero se entremezcló con esquemas de distribución que prescindieron de transiciones, antecámaras y pochés incorporando criterios de sistematización, flexibilidad e indeterminación.

Partido, carácter, composición, conforman los principios sobre los que se estructura el sistema, codificados por la didáctica académica. Pero colisionan en un momento en el que la serialidad, la indeterminación formal, la ausencia de límites y la posibilidad de ampliación infinita, le son requeridos a la disciplina. La búsqueda de una arquitectura de base científica, de una metodología para el diseño y la "teoría de sistemas" se entremezclan con préstamos y referencias de los viejos procederes.

3- Un amplio desarrollo de estos tópicos en LIERNUR, Jorge Francisco (2001) Arquitectura en la Argentina del siglo XX, La construcción de la modernidad. Buenos Aires, Fondo Nacional de las Artes

4- Para una mayor profundización de estos conceptos ver GORELIK, Adrián. (2010) Nostalgia y plan: el Estado como vanguardia. En Correspondencias, arquitectura, ciudad y cultura Buenos Aires, Argentina: Nobuko pp.93-117 
Estos valores y métodos de enseñanza, mantenían vigencia en la FAU UBA, pero se alternaban con la sorpresa y fascinación, que en la generación de jóvenes profesores, producían las recientes obras de Le Corbusier o las de Frank Lloyd Wright que por aquellos años ya tenían amplia difusión en publicaciones de libros y revistas.

Soto y Rivarola ingresaron a la Facultad en 1948 y rápidamente trabaron una profunda amistad. El primer decano de la casa de estudios, Ermete De Lorenzi, promovió la presencia de diferentes intelectuales y arquitectos europeos. Continuando una larga tradición de visitantes extranjeros, durante los años que cursaron como alumnos, fueron invitados a dictar cursos y conferencias, los italianos Pier Luigi Nervi, y Bruno Zevi, que se sumaron a las clases regulares que ofrecían los docentes: Alfredo Casares, Mauricio Repossini, Alfredo Agostini, Alberto Prebisch y Eduardo Catalano. Todos ellos entusiastas precursores y practicantes de la arquitectura moderna.

Entre 1949 y 1952 se agregaron al plantel docente los arquitectos Alberto Dodds, Mario Buschiazzo, Alfredo Villalonga, los artistas plásticos Raúl Castagnino, y Ernesto de la Cárcova, y el urbanista Carlos María Della Paolera. Este panorama heterogéneo impregnaba el ambiente académico haciendo coexistir el estudio de las vanguardias, la experimentación e investigación de las nuevas corrientes internacionales del pensamiento arquitectónico con la idea de partido, composición y valores propios del "beaux arts".

En 1953, Soto interrumpió sus estudios y siendo dibujante en la Dirección de Arquitectura de la Sub secretaría de Construcciones del Ministerio de Salud Pública de la Nación, decidió trasladarse a Tucumán, trabajando en esa provincia durante casi tres años. Integró un equipo que estaba bajo la supervisión del arquitecto Eithel Traine, quien durante esos años se desempeñó también como docente de la Escuela de Arquitectura de Tucumán, para construir la Ciudad Hospital de Horco Molle, una novedosa experiencia que en materia hospitalaria era llevada adelante, mediante el Plan Sintético de Salud Pública (1952-1958), según los principios sostenidos por el médico y entonces Ministro de Salud, Ramón Carrillo.
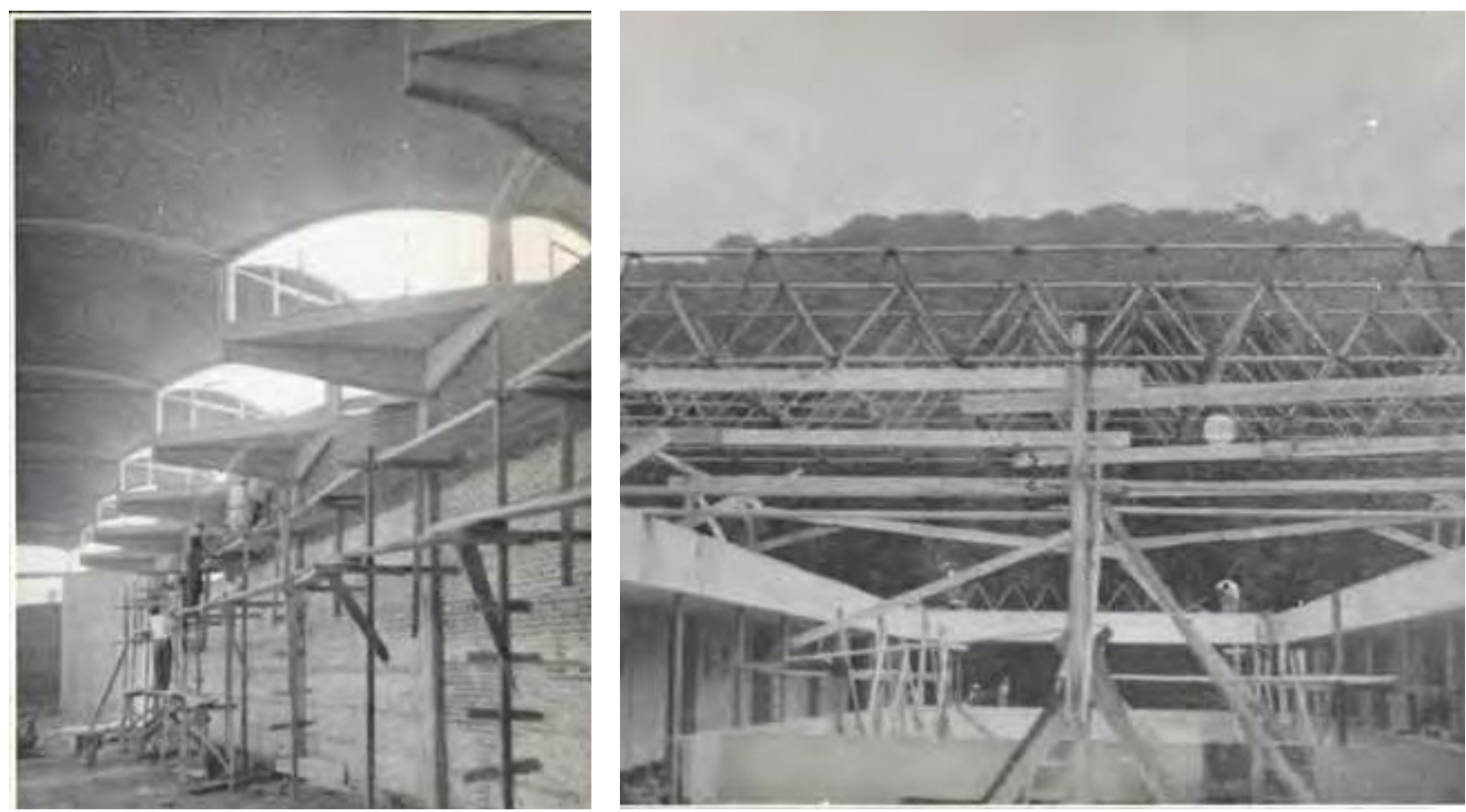

Imagen1: Ciudad Hospital de Horco Molle, Tucumán 1954; Imagen 2: Cubierta de la Escuela de Enfermerías, Ciudad Hospital de Horco Molle, Tucumuán, 1955 (M. Soto) . 
Esos años serían para Soto centrales en su formación como arquitecto, al vincularse con profesionales como Jorge Vivanco ${ }^{5}$ yal mismo tiempo la posibilidad de ejercitar, en un contacto directo con la construcción de proyectos de arquitectura, su relación práctica con técnicas constructivas y el manejo de materiales. Esta voluntad de experimentación encontró pronto, el campo de aplicación en la resolución de la cubierta de la Escuela de Enfermeras de Tucumán (1953-1954), realizada mediante la utilización nada tradicional, de los caños de las instalaciones eléctricas para conformar una estéreo estructura con la que se cubrió gran parte del patio, o en el desarrollo junto a Jesús Bermejo, Oscar Fernández Sabaté y Fernando García Barón, de las viviendas para los médicos, que se adecuaban mediante una variedad tipológica, a las condiciones cambiantes del paisaje, sitio y orientación. ${ }^{6}$

Soto regresó de Tucumán y completó sus estudios hacia mediados de 1956; Rivarola se había graduado en 1954. La situación de inestabilidad que reinaba en el campo institucional y político reflejado en el Ministerio de Salud del que ambos formaban parte, los llevó a intentar una práctica profesional en común. Realizaron múltiples concursos y proyectos en la provincia de Misiones; obtuvieron el primer premio en diciembre de 1956, para la construcción de cuatro escuelas de madera. Unos meses después, en marzo de 1957, lograron el primer premio para la construcción de seis hosterías. Durante el mismo año se les encargó el proyecto de la escuela Normal Número 1 en Leandro N. Alem, una localidad a unos $100 \mathrm{~km}$ de Posadas. Culminando la actividad de la oficina en la provincia con la obtención del primer premio, para la construcción del Instituto de Previsión Social y Hotel de la ciudad de Posadas, en 1959.

Gran parte de este grupo de obras, fueron promovidas por el plan ideado para la modernización de Misiones, que se elaboró en el marco de la provincialización de los territorios nacionales, ocurrida entre 1951 y 19557 . La transformación geopolítica impulsó necesidades programáticas, edilicias, arquitectónicas y representativas, a partir de la conformación de los gobiernos de los nuevos estados provinciales. Estos cambios no tuvieron respuestas homogéneas y fueron interpretados de manera distinta en cada caso. Así por ejemplo la construcción de la Sede de Gobierno y Dependencias Administrativas para la provincia de La Pampa, a partir del concurso ganado por los arquitectos Clorindo Testa, Boris Dabinovic, Augusto Gaido y Francisco Rossi, en 1955, constituyó una experiencia prácticamente opuesta a la que se realizó en Misiones, en donde el nuevo Gobierno Provincial eludió la construcción de un edificio para establecer su sede, buscando visibilizar su presencia, a partir de un plan urbano integral para la provincia,
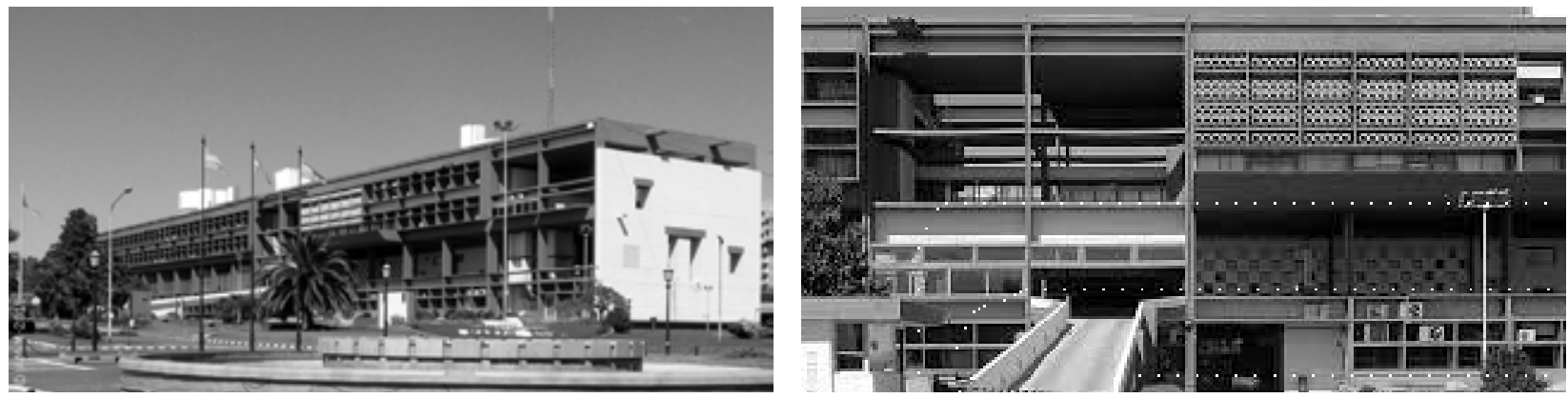

Imágenes 3 y 4: Centro Cívico de Santa Rosa La Pampa; C. Testa, B. Dabinovic; A. Gaido y F. Rossi (1955)

5- Jorge Vivanco (1912-1987): Fue Arquitecto. Formó parte del Grupo Austral, integró el Instituto de Arquitectura y Urbanismo de la Facultad de Tucumán, desarrollando el proyecto para esa casa de estudios, junto a Horacio Caminos, Eduardo Sacriste, entre otros. Elaboró el Plan Urbano para Jujuy Palpalá, entre muchos otros trabajos.

6- Las viviendas fueron proyectadas por Mario Soto, Jesús Bermejo quienes coordinaban un equipo formado por estudiantes de la Escuela de Arquitectura de Tucumán quienes asistían a los cursos dictados por Eithel Traine. Fueron construidas por la Empresa Sollazo Hermanos en 1954

7- La transformación de los territorios nacionales en provincias ocurrió entre 1951 y 1955 . La ley 1532 dictada durante el año 1884 disponía que los territorios ubicados por fuera de las 14 primitivas provincias contarían con un gobierno elegido por el Poder Ejecutivo Nacional, con acuerdo del Senado de la Nación. Las provincias que se incorporaron al arco federal de la nación a partir de 1951 fueron: Misiones, Chaco, Formosa, La Pampa, Neuquén, Río Negro, Chubut, Santa Cruz, y más recientemente Tierra del Fuego. 
uno para la ciudad de Posadas y una serie de obras cívicas, no gubernamentales, que se distribuyeron en prácticamente todo el territorio provincial. Es posible pensar estos casos, como los extremos opuestos de las operatorias puestas en marcha por los nuevos gobiernos y que pueden sintetizarse como visiones enfrentadas de centralización versus atomización, en la consolidación, planificación y construcción de los programas arquitectónicos que las nacientes organizaciones políticas requerían, poniendo de manifiesto la diversidad de prácticas empleadas, por los poderes provinciales emergentes.

El proceso de provincialización y efectiva configuración de la estructura gubernamental y administrativa de las nuevas provincias, quedó superpuesto entre el gobierno de Perón y el golpe de 1955. El gobierno militar, culminó la definitiva organización de las flamantes regiones geopolíticas y nombró en 1956 a Adolfo Pomar, como interventor, que al frente del gobierno de la Provincia de Misiones ${ }^{8}$, promovió el desarrollo de una propuesta, que pretendía conseguir la modernización del territorio misionero, basado en la construcción de obra pública y de infraestructura. El proyecto se configuró sobre la base del interrumpido, segundo Plan Quinquenal, que el gobierno peronista había diseñado, sin llegar a poner en práctica completamente.

En una designación conjunta Pomar convocó, en 1956 a la Sociedad Central de Arquitectos y a la Asociación de Profesionales de la Ingeniería y de laArquitectura de la Provincia de Misiones, para organizar los concursos a nivel nacional y estudios urbanísticos a escala provincial, que permitieron proyectar y construir un variado programa edilicio, que comprendió la realización de escuelas, comisarías, hospitales y salas sanitarias, hoteles, paradores y hosterías, para fortalecer uno de los ejes de crecimiento y expansión pensados para la nueva provincia: el turismo. De este modo, el plan ideado, buscó crear la infraestructura hotelera, que iría acompañada por el tendido de rutas y caminos necesarios, para el desarrollo de la actividad.

Entre los años 1956 y 1959, se llevó a cabo una intensa actividad en la provincia, se concursaron y construyeron gran cantidad de obras: cinco comisarías en las localidades de Libertador General San Martín; Eldorado, Villa Lanús, Campo Grande y 2 de Mayo, fueron realizadas según el proyecto premiado de los arquitectos Dabinovic, Gaido, Rossi y Testa, equipo que obtuvo, casi en simultáneo, el primer premio para la construcción de cuatro unidades sanitarias en las localidades de SanAntonio, Candelaria, Panambí y Panay y el primer premio del concurso para tres paradores u hoteles de tránsito en San Pedro, 2 de Mayo y Cerro Azul. En tanto los arquitectos Bernardo Sigal, Víctor. Sigal, César Vapñarsky y Marcos Winograd, eran premiados para realizar tres hoteles en las localidades de Bernardo de Irigoyen, Eldorado y Apóstoles. Las distinciones obtenidas en los concursos realizados por Soto y Rivarola completan la primera operatoria puesta en marcha en Misiones.

La experiencia de esta oficina transitó, desde las primeras obras ejecutadas en madera, hasta las últimas realizadas en la provincia en hormigón armado, por un camino de investigación y búsqueda, que combinó la posibilidad de conciliar, dentro de una misma producción arquitectónica, la fusión entre el accionar profesional y la experimentación, participando de corrientes del pensamiento arquitectónico contemporáneo, que comenzaban a ocupar un lugar en la teoría disciplinar.

Esta tesis propone iluminar, a través de su arquitectura, los procesos de ideación, hacia la concreción material, buscando verificar las transformaciones, préstamos y permanencias de métodos de proyectar, propios de la arquitectura "beaux arts" solapados a las nuevas maneras. Pero al mismo tiempo poner en relación a sus obras con los encargos del Estado nacional, en la encrucijada entre el desarrollo de una "nueva monumentalidad", "nacionalismo" y funcionalidad; "estilo y carácter". 

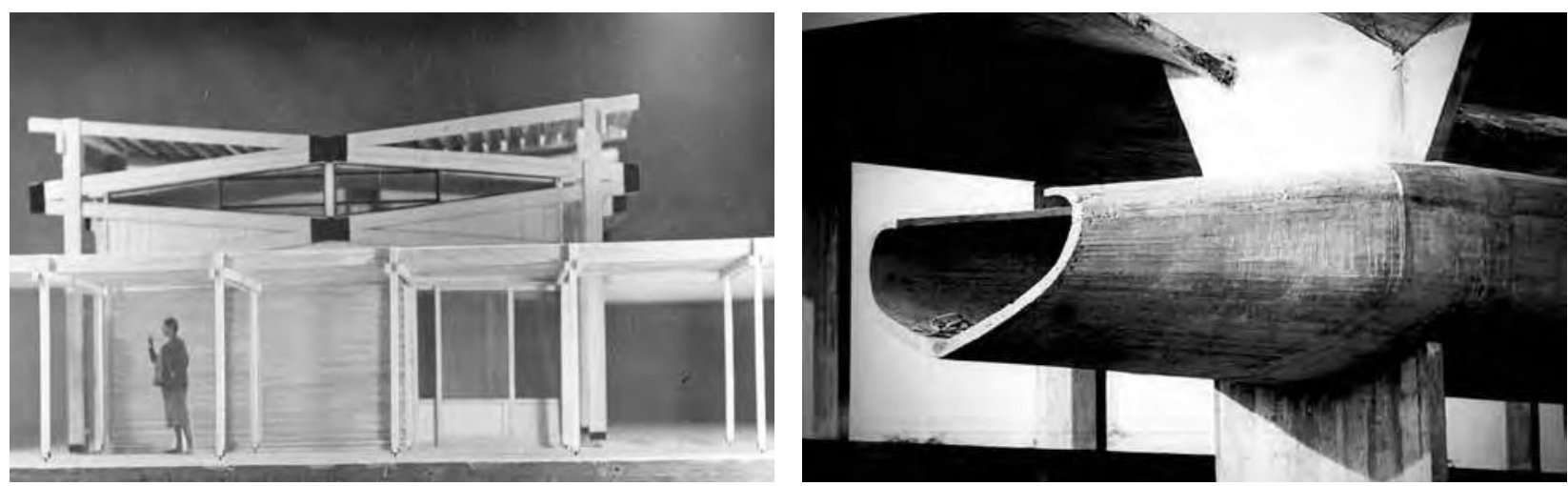

Imagen 5: Maqueta del concurso para las cuatro escuelas de madera, Soto y Rivarola (1956). Imagen 6: Detalle de la gárgola de Hormigón Armado de la Escuela en Alem. Soto y Rivarola (1957)

El paso de las obras en sectores de baja densidad y mediana escala, a obras de mayor porte y de inserción netamente urbana, permite analizar los diversos criterios y posturas utilizados por los arquitectos. La relación entre la ciudad, la forma arquitectónica y su planteo, exhibiendo, no solo la problemática del momento y las preocupaciones del debate teórico contemporáneo, sino mecanismos centrales del proceso de ideación arquitectónico.

Laaproximación hacia la materialidad de sus edificios admite vislumbrar que el sistema constructivo dio origen a otro sistema que procede y depende de la construcción y que se constituyó como un sistema estético. El mismo componente es al mismo tiempo elemento de utilidad y belleza. Evitando cierta uniformidad extendida en la concreción material de algunas obras consideradas modernas, Soto y Rivarola indagaron en las más diversas variaciones dentro del uso de la madera y luego del hormigón, profundizando el cometido del arquitecto, como organizador razonable de los materiales que tiene a su disposición y del trabajo de quienes lo utilizan. La búsqueda de la simplificación de los elementos arquitectónicos, que se concreta sin resignar la riqueza espacial, facilita su organización más efectiva produciendo un vínculo muy estrecho entre el arquitecto que elabora y el operario que construye. Esta relación siempre fue atendida por la oficina, teniendo muy en claro que las piezas gráficas, planos y detalles, debían ser de sencilla lectura. La elaboración de múltiples dibujos a mano alzada, realizados por Soto, permitía hacer más fluida aún esa comunicación.

Es posible ver la producción de Soto y Rivarola como un recorrido desde la grilla estructural hacia la resistencia por forma ${ }^{10}$. Este camino logra verificarse al analizar sus primeras obras, resueltas mediante el entramado geométrico de piezas de madera encastradas y en las últimas sostenidas a partir de la cubierta de hormigón tipo cáscara de la Escuela Normal $\mathrm{N}^{\circ} 1$ en Leandro N. Alem.

Madera, hormigón composición y sistema, son los tópicos que atraviesan la obra de Soto y Rivarola y permiten, a partir de su identificación y reconocimiento, realizar el estudio de su producción. Estos temas se constituyen en elementos que la caracterizan y pueden identificarse tanto en las decisiones de proyecto como en cada detalle constructivo, exponiendo la dimensión significativa de la arquitectura.

9- Anatole Senkevich, realiza un estudio de los conceptos de Moisei Ginzburg en SENKEVICH, Anatole (1982) "Moisei Ginsburg and the emergence of a Constructivist Theory of Architecture. En GINZBURG, Moisei. Style and époch. Cambridge M.A. Mit press

10- Para una mayor profundización de este concepto: ABRAM Joseph" Nervi. P.L. La resistenza per forma, la forma come struttura”.

En: C. OLMO Carlo. CHIORINO, Cristiana (a cura di) (2010) L'Architettura come sfida, Milano Silvana Editoriale pp.42-47 

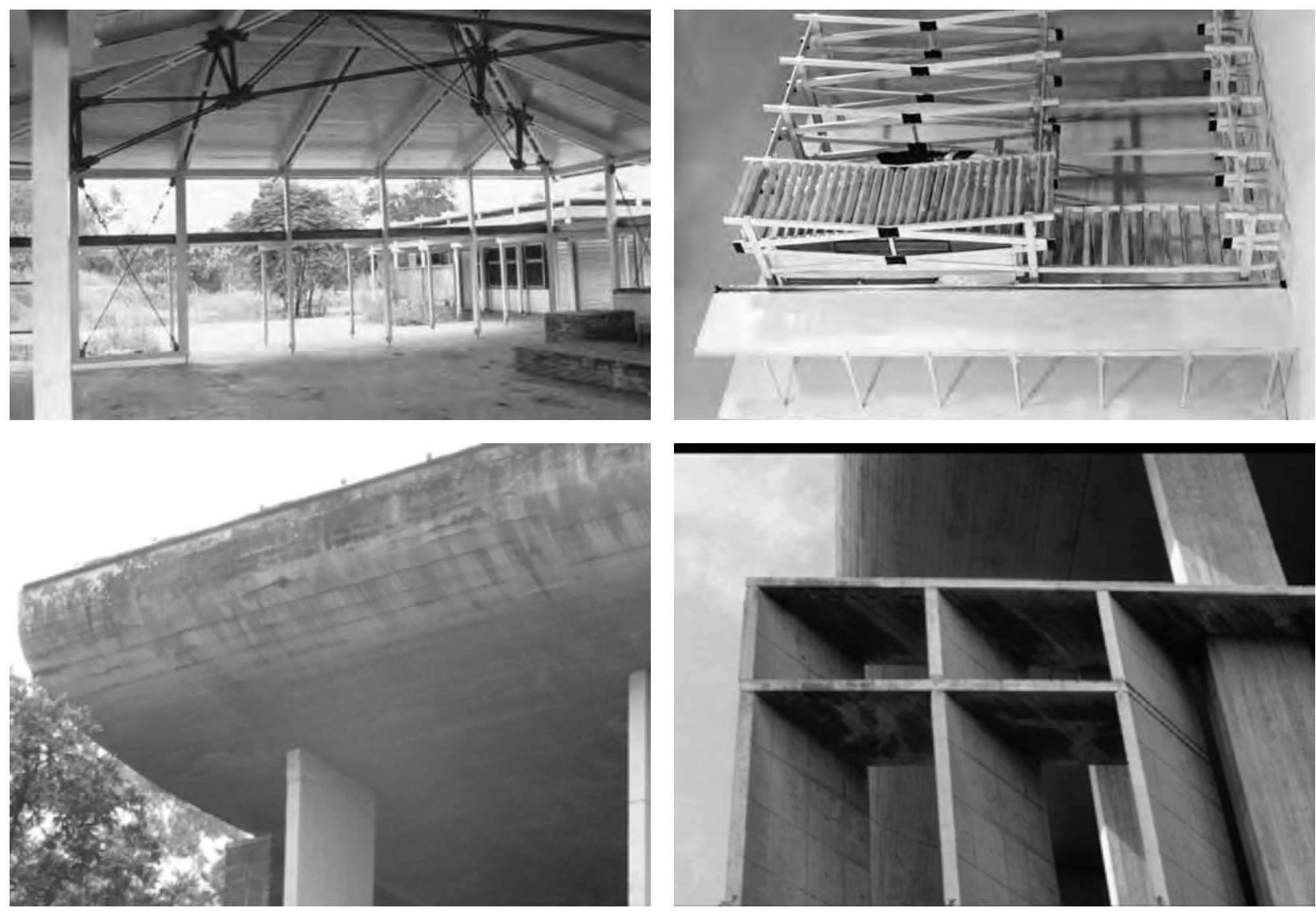

Imagen 7: Vista interior del comedor de una de las escuelas. Cabreadas y detalles resolución de la cubierta. Imagen: Soto y Rivarola 8: Maqueta del concurso para las cuatro escuelas (1956). Soto y Rivarola. Imagen 9: Vista parcial de la cubierta de la Escuela en Alem; Imagen 10: Vista parcial de los parasoles de la fachada del IPS Posadas, ambas obras de Soto y Rivarola

Es necesario reflexionar, sobre el carácter "monumental" de sus obras, entendido desde la perspectiva propugnada por Giedion, Sert y Léger, a través de "los nueve puntos sobre monumentalidad" llamando a la exaltación, la alegría y la significación de los edificios destinados a la sensibilidad social.11 Previamente en el armado de las escuelas y en las hosterías (1956-1957), se verifica la intención de la construcción monumental desde la concepción del anti-monumento. Edificios bajos, a nivel del suelo, a escala humana, se relacionan con pérgolas y semi-cubiertos que aportan alturas y planos de referencia. La madera como pieza y material fundamental, prácticamente resuelve todas las instancias constructivas. Uniones, encastres, permiten la fácil manipulación y posibilitan un sencillo armado. Esta concepción bidireccional en el planteo de la obra permite que los extremos situados entre la elaboración y el uso se conecten a partir de reconocer y unificar la escala del hombre como constructor y usuario.

En los casos de la Escuela en Alem (1957) y del Instituto de Previsión Social de la Ciudad de Posadas (IPS) (1959), a través de la técnica constructiva pondera y ubica al hormigón como material fundamental, cuya plasticidad lo predispone a modelados diversos, esenciales en la determinación del sistema en equilibrio: forma y resistencia, encuentran un diálogo y expresión simultáneas. Las cáscaras cónicas de doble curvatura aportan de por sí, expresividad formal y condición de monumento. Aún sin ser el objetivo, el edificio adquiere cierto carácter solemne, pero rehúye de su condición originaria y como antídoto busca la escala humana, por debajo de estas cubiertas, con una serie de elementos, que ubican siempre, la estatura del hombre y procuran brindar la sensación de cobijo. 


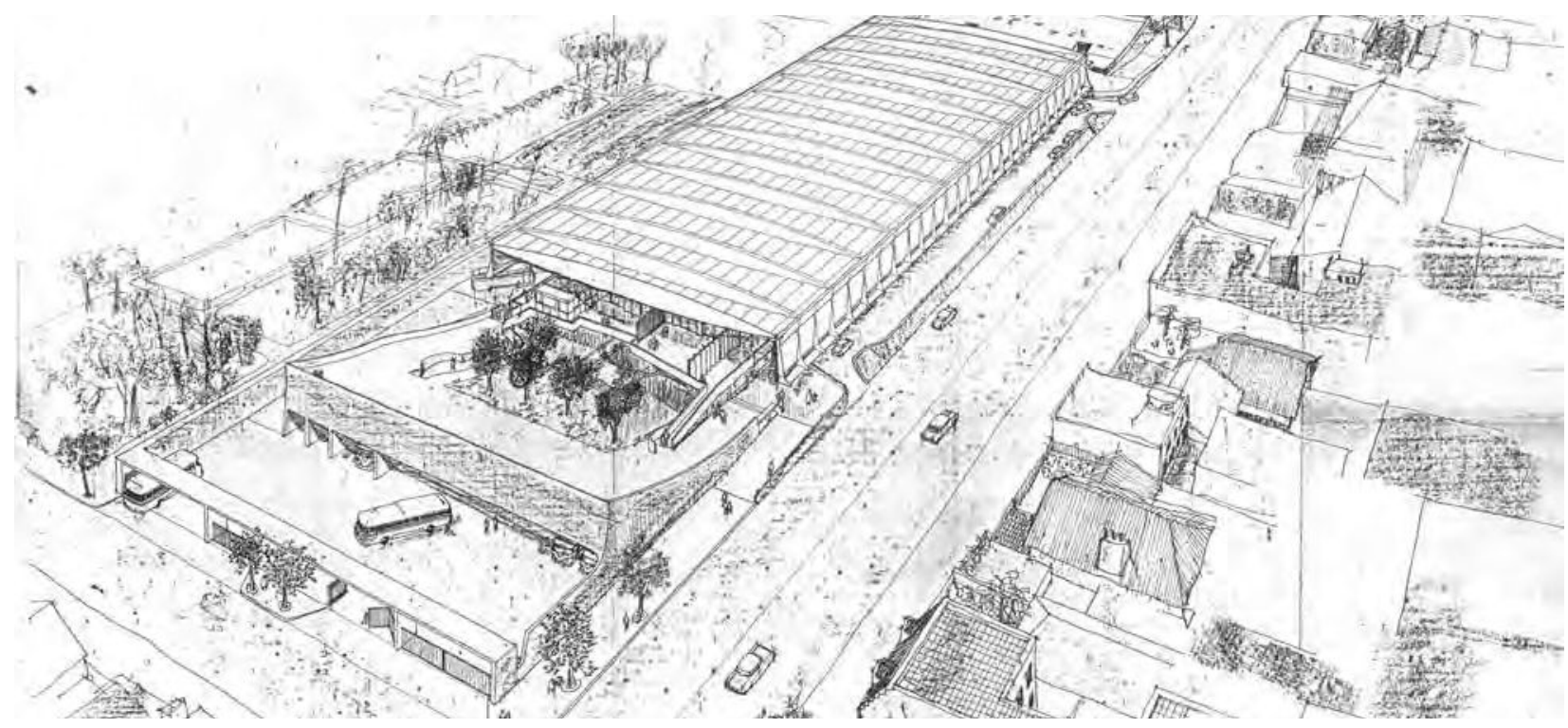

Imagen 11: Perspectiva aerea del panel del concurso de la Terminal de Ómnibus de Resistencia, Chaco

El primer premio, no construido, proyectado por Soto y Rivarola para la terminal de ómnibus de la ciudad de Resistencia en la provincia de Chaco (1964), podría ser el eslabón que atase el tránsito, desde las primeras obras en madera, que pasando por el desarrollo articulado y artesanal del hormigón, desembocasen, de manera irreversible, en la más profunda racionalización de las aspiraciones nacionales, escasamente concretadas, del empleo de la prefabricación. De este modo se podrían corroborar los distintos momentos del debate disciplinar con las intrusiones, impactos, e interferencias en los proyectos de la oficina. En tal sentido, y como profesionales preocupados en brindar respuestas a las demandas de la sociedad, en términos de velocidad y racionalización de los tiempos de ejecución, no podían mantenerse al margen e intentar incluir la prefabricación en su arquitectura. Es desde esa perspectiva que diseñan el proyecto para la terminal de Resistencia. Una serie de piezas agregables y ensamblables de hormigón, serían dispuestas en torno a las vigas pretensadas, realizadas en fábricas y trasladadas a pie de obra. Se completarían con un sistema para la cubierta, que soportado sobre cruciformes columnas cerrarían el volumen total.

Las circunstancias, siempre cambiantes y traumáticas de la historia política argentina impidieron su realización, dejando trunco un camino que se interrumpía, a muy poco de iniciarse. El golpe militar que depuso aArturo Illia el 28 de junio de 1966, dejó en suspenso su realización y al mismo tiempo promovió una serie de factores que desembocarían en el enfrentamiento de posturas y el abandono de muchos artistas de su campo disciplinar específico para pasar a una lucha política cada vez más radicalizada. "Tucumán arde"12 (noviembre de 1968) sirve de caso testigo. En aquella exposición fue tan intensa la experiencia de artistas y militantes que los condujeron a la convicción de que no era posible pensar en la transformación de la realidad a través del arte. Soto, en ese momento, era profesor de la Facultad de Arquitectura y Urbanismo de la Universidad de Buenos Aires, atravesada por la recordada "noche de los bastones largos", ocurrida el 29 de julio de 1966.

A partir de allí, un lento, pero inexorable distanciamiento haría que la tan exitosa sociedad conformada por Soto y Rivarola, comenzara a trabajar de forma espaciada, y sus principales integrantes a recorrer caminos diferentes, cambiando el foco de interés, principalmente de Soto, que experimentó la necesidad de volcar su espíritu creativo a la transformación de la realidad social por la vía de la acción política, antes que por la ideación de espacios ${ }^{13}$.

12- Para una mayor profundización acerca del tema remitirse a: LONGONI. Ana; MESTMAN Mariano (2000), Del Di Tella a "Tucumán Arde" Vanguardia artística y política en el "68 argentino". Buenos Aires. El Cielo por asalto.

13- - TOGNERI Jorge. "Mario Soto, un ser comprometido". s/f, Recuperado de http://www.mariosoto.net en el que dice: “...cuando llegó el momento de las decisiones mayores la persona política dedicada a construir el futuro, primó sobre la persona arquitecto dedicada a construir espacios". 
Este trabajo se estructura siguiendo el proceso de ideación de la obra de Estado de Soto y Rivarola. En la primera parte se estudian los pasos de una cronología que se inicia con los premios de los concursos de las escuelas y hosterías, pensadas y construidas mediante el empleo de la madera como material constitutivo, para pasar luego a la escuela en Alem y el IPS de Posadas, en las que la presencia del hormigón impone otra lectura de la imagen acabada de los edificios ${ }^{14}$, su materialidad y carácter; reconstruyendo el camino de cada proyecto a través de la individualización de sus diferentes etapas. En la segunda parte se analizan estas obras, intentando dejar al descubierto los procesos temas y consideraciones tenidas en cuenta por los arquitectos al momento de su proyectación. En la tercera parte, a partir de la confrontación de estos dos grupos de obras, es posible formular la hipótesis acerca de la existencia de un punto de inflexión en el desarrollo de su producción, permitiendo especular con la aparición de un cambio de paradigma en el acercamiento de Soto y Rivarola a la arquitectura.

El pasaje de un pensamiento bidimensional, surgido de la planta, hacia otro originado a partir de la comprensión delespacio.Almismotiempo verificar el abandono de planteos de volúmenes interconectados y dispersos, en la dirección de una búsqueda motivada en conseguir configuraciones unitarias y compactas, en la que los principios de serialidad e indeterminación, corroborados en sus primeros proyectos, cedieron el paso a la definición y lo concreto. Es posible observar a partir de allí, cómo la arquitectura de Soto y Rivarola se separó de lo prototípico y repetitivo haciéndose única y singular.

El énfasis puesto en las descripciones de los edificios se debe a la intención de contribuir a una comprensión más amplia de los procesos de ideación arquitectónica. Tensada desde los primeros bosquejos, por los condicionantes políticos, presupuestarios hasta la materialización de una arquitectura adecuada, no solo para fines operativos sino fundamentalmente cívicos y representativos. Se pretende descorrer la compleja trama que se entrecruza sobre el proyecto arquitectónico, superpuesta a las particulares metodologías puestas en juego por los arquitectos al amparo, en este caso, de su heterogénea formación.

Finalmente esta tesis no propone concentrarse en la historia personal de sus protagonistas sino que se inscribe en el estudio de un ciclo cultural en el que ellos participan, para identificar lo que Manfredo Tafuri observaba:

"En la historia de la arquitectura existen momentos particulares o "casos" que asumen un valor crítico determinante para la comprensión de "ciclos culturales" completos. Nos referimos a edificios o producciones unitarias, que parecen marcar un puntode pasaje, un momento de crisis en una cultura que ha llegado a un alto grado de madurez y que precisamente en su momento de máxima intensidad siente de un modo confuso la necesidad de superarse a sí misma, siente la necesidad de verificar su propia coherencia histórica, dando así origen a obras que recapitulan sobre ellas mismas, planteando momentos de continuidadycrisisidentificandoel criterio de loúnico ylo eterno."15

14- - La aproximación a la idea de "imagen" debe ser interpretada desde la mirada que realiza BANHAM Reyner (1955) "The new brutalism" En: The Architectural Review, December pp. 335-358, -anterior a su libro El brutalismo en Arquitectura, ética o estética (1967)-, en el que utilizó el término para escapar a la estética clásica y hacer referencia a algo, que aunque no se ajustaba a los cánones tradicionales de juicio era visualmente valioso y requería que el edificio fuera una entidad visual que se percibiera de inmediato y que la forma que capta el ojo se confirmara por la experiencia surgida del uso del edificio. "Algo que visualmente es valioso, pero no necesariamente según los estándares de la estética clásica" Banham define además imagen como aquello que visto afecta las emociones

15- TAFURI Manfredo. (1962). Problemi di crítica e problemi di datazione in due monumenti taorminesi: il Palazzo dei Duchi di Stefano e la Badía Vecchia. Venecia, Italia: Quaderni dell istituto di Storia dellÁrchitettura p.51. 

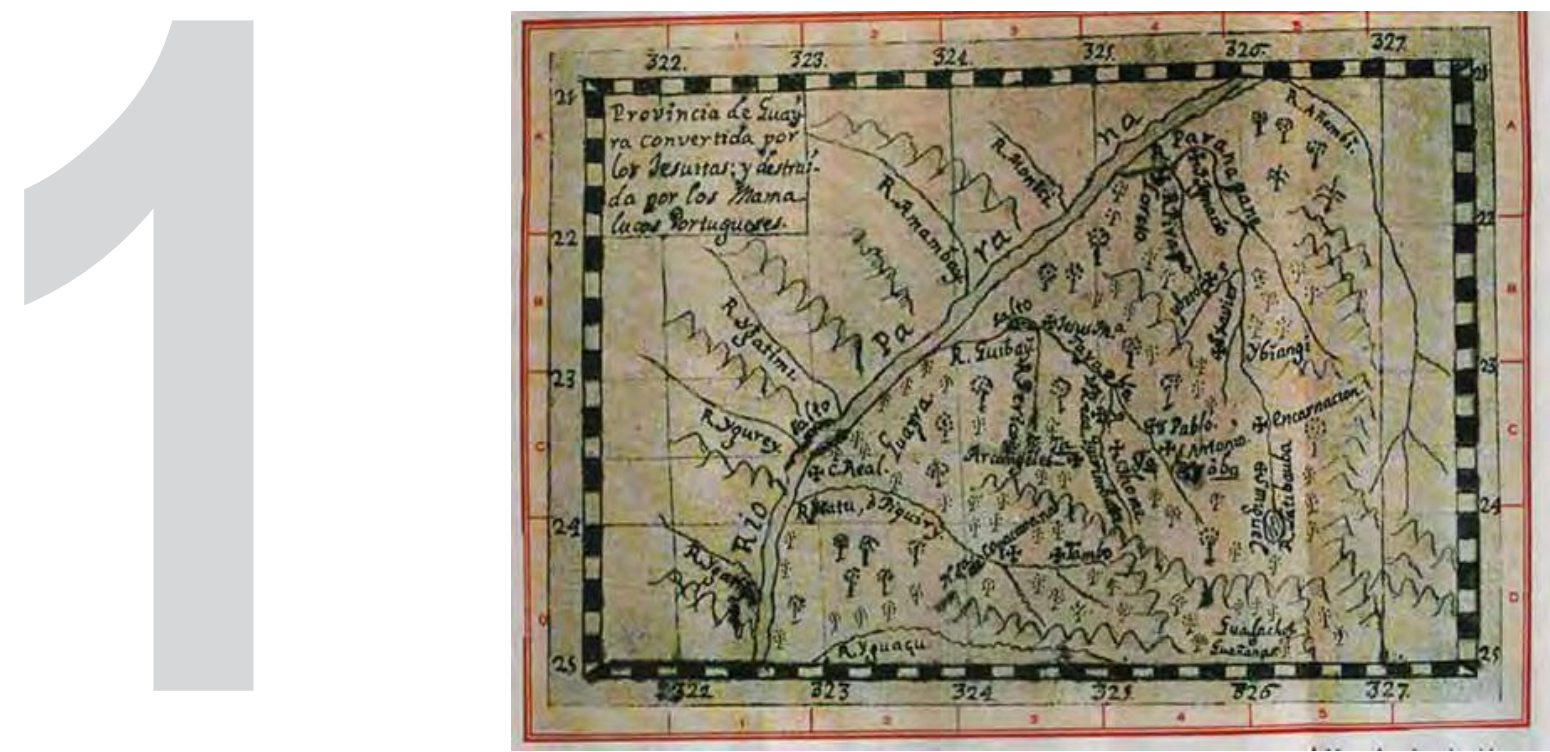

Imagen12: Mapa de las provincias jesuíticas 


\section{Crisis del sistema económico en los estados modernos}

El "Gran Crac"16 económico internacional, ocurrido durante 1929, marcó una profunda ruptura con el mundo conocido, "una catástrofe que acabó con cualquier pretensión de restablecer la economía y la sociedad del siglo XIX, los acontecimientos del período 1929-1933 hicieron imposible e impensable un retorno a la situación mundial existente en 1913"17. Según Eric Hobsbawn, la crisis económica y sus repercusiones mundiales, explica en gran medida, la aparición de Adolf Hitler en Alemania y de Franklin D. Roosevelt en Estados Unidos y la conciencia del sistema soviético como un antagonista económico y una alternativa al sistema capitalista mundial ${ }^{18}$. El mundo de la segunda mitad del siglo XX es incomprensible sin entender el impacto de esta catástrofe económica; El auge de la doctrina keynesiana (John Maynard Keynes 1883/1946), quedaba demostrado, en apariencia, por las consecuencias de la "Gran Depresión", al igual que la efectividad que a los ojos de Occidente, habían tenido las políticas de la URSS, supuestamente inmune a la crisis mediante la implantación y puesta en marcha de los "planes quinquenales" entre 1929 y 1940 o el New Deal, impulsado por Roosevelt en Estados Unidos a partir de 1932. América Latina no quedó al margen y manifestó de distintos modos el impacto de la crisis: Chile, por ejemplo, desalojó del poder a uno de los escasos dictadores-presidentes, antes de la era Pinochet, Carlos Ibáñez; en Brasil se puso fin a la "vieja República oligárquica" de 1899-1930 y se estableció en el poder a Getulio Vargas, que condujo un gobierno durante veinte años, señalado por algunos autores como de corte "populista-nacionalista" 19 .

En Argentina se inició un período de gobiernos militares, y la breve presidencia de José Félix Uriburu, quien desalojó por la fuerza a Hipólito Yrigoyen el 8 de septiembre de 1930, fue seguida por, la del también presidente de facto, Agustín Justo. Durante su presidencia (20 de febrero de 1932, 20 de febrero de 1938), en 1933 se presentó el primer Plan de Acción Económica Nacional, estructurado en una serie de medidas que fortalecían el rol intervencionista del Estado sobre la economía, desde una perspectiva nacionalista y proteccionista buscaba la promoción integral territorial, ${ }^{20}$ promoviendo una participación activa del gobierno argentino, que mediante la implementación de una "política anticrisis" buscaba tener una mayor participación en la economía.

16 -La crisis del veintinueve, alude a la caída de la bolsa de valores ocurrida en Estados Unidos el 29 de octubre de 1929 y que se prolongó durante más de un mes, con consecuencias devastadoras para las economías de muchos países, que no pudieron evitar el impacto ni sus consecuencias, independientemente del rol que tuvieran en la economía mundial, ya que países productores , ricos o pobres se vieron afectados por igual, por caídas en las exportaciones, en las rentas nacionales, ingresos fiscales y comercio internacional, con aumento del desempleo. Caída de la Industria y de la construcción y los precios de las materias primas.

17 -HOBSBAWN, E (2008). "La era de las catástrofes”. En HOBSBAWN, E. Historia del siglo XX. Buenos Aires. Crítica. p.114.

18 -HOBSBAWN, E (2008). “La era de las catástrofes”. En HOBSBAWN, E. En Historia del siglo XX...cit. p.93.

19 -HOBSAWN, E. (2008). "La era de las catástrofes”. En HOBSBAWN, E. En Historia del siglo XX...cit.p.113

20 -BALLENT, Anahi, GORELIK, Adrián. (2001) "País urbano o país rural: la modernización territorial y su crisis" en Cattaruzza, A (comp.), Nueva Historia Argentina Tomo 7.Buenos Aires 2001. Sudamericana p.147. 
Es interesante notar, que el término "Estado de bienestar", en su concepción moderna, no comenzó a utilizarse hasta después de 1940 y la aparición hacia 1930 del psicólogo Émile Coué y la autosugestión optimista, ejemplificada en la frase, de amplia difusión durante la década de 1930: "cada día estoy mejor, en todos los sentidos"21, sumados al corrimiento hacia la izquierda en algunos gobiernos de países de la región o hacia otros de corte nacionalista- populista ${ }^{22}$, permiten dimensionar la magnitud y repercusión que el quebranto económico de 1929 y sus efectos traumáticos, tuvieron en América Latina.

El estallido de la Segunda Guerra Mundial en 1939 marcó la aparición de un nuevo escenario geopolítico introduciendo un novedoso marco para las economías latinoamericanas. La necesidad de sustituir importaciones, incentivó a la industria interna como sector principal de la economía. ${ }^{23}$ Durante la presidencia de Ramón S. Castillo (27 de junio de 1942, 4 de junio de 1943) se presentó un Plan de Reactivación Económica cuyas medidas principales buscaban tener por parte del Estado, el incentivo a la industria, a la obra pública y privada y principalmente el control de la producción agraria, la actividad financiera y monetaria.

La “Revolución del 4 de junio de 1943" y la asunción del Teniente General Arturo Franklin Rawson, primero y luego de su renuncia tres días después, la del General Pedro Pablo Ramírez, inició un período nacionalista "orientado a renovar la conciencia patria y dar contenido ideológico argentino al país entero"24". El avance de la política estatal en la política industrial y el aumento del nivel de vida a través de la intervención social promovida desde el Estado constituyeron las bases sobre las que Ramírez intentó establecer el orden en el país, marcado por la crisis institucional.

La fórmula presidencial Perón y Hortensio Quijano, se impuso en las elecciones del 24 de febrero de 1946, poniendo una pausa al período caracterizado por la sucesión de gobiernos de facto (Pedro Pablo Ramírez 1943/1944, Edelmiro Farrell, 1944/1946). Como una de las primeras acciones de gobierno, Juan Domingo Perón impulsó el primer Plan quinquenal, que ubicó al Estado como promotor de condiciones económicas favorables, persiguiendo como objetivos: lograr la independencia económica, la soberanía política y la justicia social. ${ }^{25}$ Estos quedaban claramente explicitados en su enunciado: “...se define un Plan Quinquenal, como el planeamiento durante cinco años, de lo que debe realizarse en un país, para que la máquina nacional funcione mejor y de mayor rendimiento, para que el pueblo sea más feliz y disfrute de mayor bienestar". ${ }^{26}$

21 -HOBSBAWN, E. (2008)."La era de las catástrofes”...cit.p.117.

22 -De acuerdo con la clasificación propuesta por Buchrucker. C, en las filas de los militares revolucionarios se observaron las siguientes tendencias político-ideológicas: “...1) la línea del nacionalismo restaurador, que tuvo máxima influencia bajo la gestión del general Ramírez. 2) La tendencia nacionalista populista, cuya cabeza vino a ser el coronel Perón, y que logró imponerse bajo Farrell. 3) El grupo de oficiales aliadófilos, generalmente simpatizantes del conservadorismo y del radicalismo antipersonalista...",BUCHRUCKER, Cristian. (1987). Nacionalismo y Peronismo. La Argentina en la crisis ideológica mundial (1927-1955). En La Argentina en la crisis ideológica mundial (282). Buenos Aires. Sudamericana. p.282.

23 -HALPERÍN DONGHI, Tulio(1986). Historia contemporánea de América Latina. Madrid.Alianza. Es interesante al respecto el análisis que realiza GORELIK,Adrián (2011) en el que sostiene que a la sustitución de importaciones de bienes materiales le correspondió un correlato en términos de afirmación cultural, que buscó situar sus fuentes en la raíz de lo "nacional” GORELIK, Adrián (2011). Correspondencias...cit.p.94.

24 -Pedro Pablo Ramírez, declaración pública recogida en numerosos medios gráficos y radiales: 8 de junio en Noticias Gráficas, 8 de junio de 1943.

25 -PRESIDENCIA DE LA NACIÓN. Subsecretaría de informaciones. (1952) Qué es un Plan Quinquenal. Buenos Aires. p.07.

26 -PRESIDENCIA DE LA NACIÓN. Subsecretaría de informaciones.(1952) Qué es un Plan Quinquenal...cit. p.05. 
El 11 de noviembre de 1951, son elegidos para un segundo mandato Perón y Alberto Tessaire, previa reforma constitucional que entre otras modificaciones permitió, a instancias de Eva Duarte de Perón, por primera vez en la historia argentina votar a las mujeres. Este mandato estuvo signado por un contundente cambio de rumbo, principalmente en los aspectos económicos. El déficit externo, la creciente inflación interna, motivaron una serie de medidas de corte ortodoxo, buscaron conseguir una restricción del gasto público, lograr una tregua entre empresarios y trabajadores para neutralizar la puja distributiva, el congelamiento de precios y salarios, por el término de dos años, tiempo durante el cual se suspendían las llamadas negociaciones "colectivas"27

En el invierno de 1952, la muerte de Eva Perón, referente político popular y una inflación angustiante, se sumaron a la falta de alimentos y a los cortes de energía. La puesta en marcha del segundo Plan Quinquenal, pensado para tener vigencia entre 1953 y 1957, se iniciaba dentro de un país que se encaminaba a experimentar una crisis muy profunda.

En 1953 se promulgó la ley $14.222^{28}$ de radicación de capitales extranjeros. Se pretendía mejorar la relación con los Estados Unidos, captar capitales internacionales, lograr asistencia técnica que impulsara la modernización industrial del país. Enfrentamientos internos, agudización de los problemas económicos y una oposición política cada vez más contrapuesta, motivó el alzamiento de un sector de las Fuerzas Armadas que bombardeó la Plaza de Mayo, el 16 de junio de 1955. Apenas unos meses después, el 16 de septiembre el general Eduardo Lonardi comandaría un levantamiento del ejército, que conjuntamente con la armada motivó la renuncia de Perón y su exilio en Paraguay. El escenario político se vería ocupado por la alternancia entre dos opciones representadas por "Libertadores" y "Desarrollistas". Las políticas que en Argentina habían expresado y orientado el proceso de sustitución de importaciones y relativo cierre del mercado interno experimentaron un cambio de signo con el derrocamiento del general Perón.

El General Pedro Eugenio Aramburu reemplazó al General Lonardi el 13 de noviembre de 1955 y llamó, una vez proscripto el peronismo, a elecciones. En 1958 fue elegido presidente Arturo Frondizi, quien inició un período de apertura económica, política y cultural del país.La nueva política aplicada, propugnaba una suerte de "salto hacia adelante" de las estructuras productivas a cualquier precio, fue aplicada en otros países latinoamericanos, especialmente en Brasil, e identificada con la idea del "desarrollismo".

Uno de los elementos claves en la aplicación de esa política en la Argentina fue el ofrecimiento de máximas ventajas para atraer capitales extranjeros en las áreas más importantes de explotación minera y desarrollo industrial. El 4 de diciembre de 1958, el Congreso Nacional promulgó una nueva ley de radicación de capitales, la número 14.780, que modificaba a la sancionada en 1953, sobre la que se basó una gran transformación, especialmente en las áreas de explotación de petróleo, energética, siderúrgica, y de producción de automóviles.

27 -El decreto $\mathrm{N}^{\circ} 23.852$ de 1945 conocido como Ley de Asociaciones Profesionales estableció un sistema cuyas principales características pueden sintetizarse en: sindicalización por actividad económica antes que por oficio o empresa, reconocimiento de un solo sindicato por actividad, obligación a los empleadores a negociar con el sindicato con reconocimiento legal y aplicación al conjunto de los trabajadores del sector de los resultados de la negociación, se institucionaliza también la existencia de una central única de trabajadores. Por medio de los convenios colectivos de trabajo, los sindicatos negocian las subas salariales con los sectores que representan a las principales empresas.

28 -Ley 14.222 Ingreso al país de capitales extranjeros para invertirse en la industria y minería. Nro. de asiento 953-08-0350. Sancionada el 21 de agosto de 1953 y promulgada el 26 de agosto de 1953 
La extrema pobreza, el autoritarismo político, la acumulación de riquezas en pocas manos, las muchas veces brutal intervención de potencias extranjeras en asuntos internos de los países, había acumulado enormes tensiones en la sociedad latinoamericana. $Y$ esas tensiones tendrían en 1959 su más poderoso estallido en la Revolución Cubana, lo que trajo importantes consecuencias para las sociedades y las culturas de esos países. El "desarrollismo, por tanto, era propuesto por los sectores más moderados como una alternativa a la "Revolución". ${ }^{29}$

En este escenario de transiciones entre gobiernos democráticos y golpes de estado, cívico militares, de resistencias políticas y reconfiguración del espacio político internacional, con la conformación de un mundo bipolar y sus tensiones, se establece el período de estudio. ${ }^{30}$ Marcado también por transformaciones de orden interno: la provincialización de los territorios nacionales ocurridos entre 1951 y 1955, que motivaron la voluntad de proveer los espacios necesarios para contener a las nuevas instituciones, sedes de los nuevos gobiernos y administraciones de reciente formación.

En el campo arquitectónico, en 1948 Enrico Tedeschi, un joven prominente de la Italia mussoliniana llegó a la Argentina con el propósito de participar del gigantesco emprendimiento universitario que Perón propulsaba para Tucumán. Tedeschi, como señala Liernur (2008), tuvo un rol decisivo en la formación de una escuela historiográfica en la Argentina ${ }^{31}$. Un momento en el que coincidían y convivían dos corrientes opuestas dentro de ese organismo; la de Eduardo Catalano orientado a las investigaciones tecnológicas y la de Eduardo Sacriste, que junto a Hilario Zalba indagaban en una arquitectura que experimentaba con temas autóctonos. Junto a Tedeschi, el escenario de la segunda posguerra europea, dispuso a una forzada retirada a figuras como Cino Calcaprina, coautor del Monumento a las Fosas Ardeatinas, así como Alberto La Padula autor del Palazzo della Civiltá Italiana, al igual que otras figuras del ambiente arquitectónico italiano desarrollaron su actividad en América Latina, a la espera de la finalización de los conflictos y la reconstrucción europea. Del mismo modo, Ernesto Rogers, Luigi Piccinato o Pier Luigi Nervi, estrecharon, en el impasse que produjo la inmediata posguerra, sus relaciones con el gobierno argentino.

Richard Neutra fue invitado a la Argentina en 1954, dictando una serie de conferencias en la Escuela de Arquitectura y Marcel Breuer construyó un restaurante en Mar del Plata, producto de su visita de 1948, Le Corbusier, realizó varios viajes a América Latina ${ }^{32}$ y construyó la casa Curutchet en la Ciudad de La Plata entre 1949 y 1953; con menos suerte Walter Gropius intentó establecer una oficina en Buenos Aires antes de emigrar a Inglaterra

Un intenso debate disciplinar planteaba una profunda crisis y ponía bajo revisión a la primera modernidad, dando lugar al resurgimiento de un nuevo clasicismo, aparecido como consecuencia, por la falta de signos representativos en las materializaciones realizadas por la "arquitectura moderna".

29 -LIERNUR, Jorge Francisco (2008). "Construcciones industriales y arquitectura a fin de siglo: entre el envoltorio y el mito". En Trazas de futuro. Santa Fe.UNL. pp.269-270

30 -ROMERO, Luis Alberto.(2012). Breve Historia Contemporánea de la Argentina 1916/2010. Buenos Aires.Fondo de Cultura Económica.pp.111;140;153;157.

31 -LIERNUR Jorge Francisco (2008). "Un nuevo mundo para el espíritu nuevo: los descubrimientos de América Latina por la cultura arquitectónica del siglo XX". En: Trazas de futuro...cit.p.42.

32 -LIERNUR Jorge Francisco (2008). “Un nuevo mundo”...cit. p.40. 
En esta zona, plagada de búsquedas y reconfiguraciones, tanto en el campo profesional, como en el político y territorial, se situó la producción de Soto y Rivarola. En la encrucijada entre "construir", "componer" y proyectar una arquitectura de "partido", con "carácter" y a la vez "moderna", mientras sus autores buscaban constituirse como agentes de esta transformación. En este juego de palabras, que esconde una densa trama conceptual se ubican estos jóvenes arquitectos, que interpretaron las necesidades de un país que se transformó generando demandas concretas. A través de su obra y de este particular momento, es posible visualizar otros casos que se dan de manera simultánea en Argentina. Efectivamente estas experiencias participan de un desarrollo análogo y en paralelo, al que se está produciendo en otras provincias de reciente conformación.

Será necesario profundizar el estudio de las transformaciones político-territoriales que se produjeron en los primeros años de 1950, ya que explican la promoción y construcción de variados programas arquitectónicos y el crecimiento de una intensa actividad en las nuevas provincias.

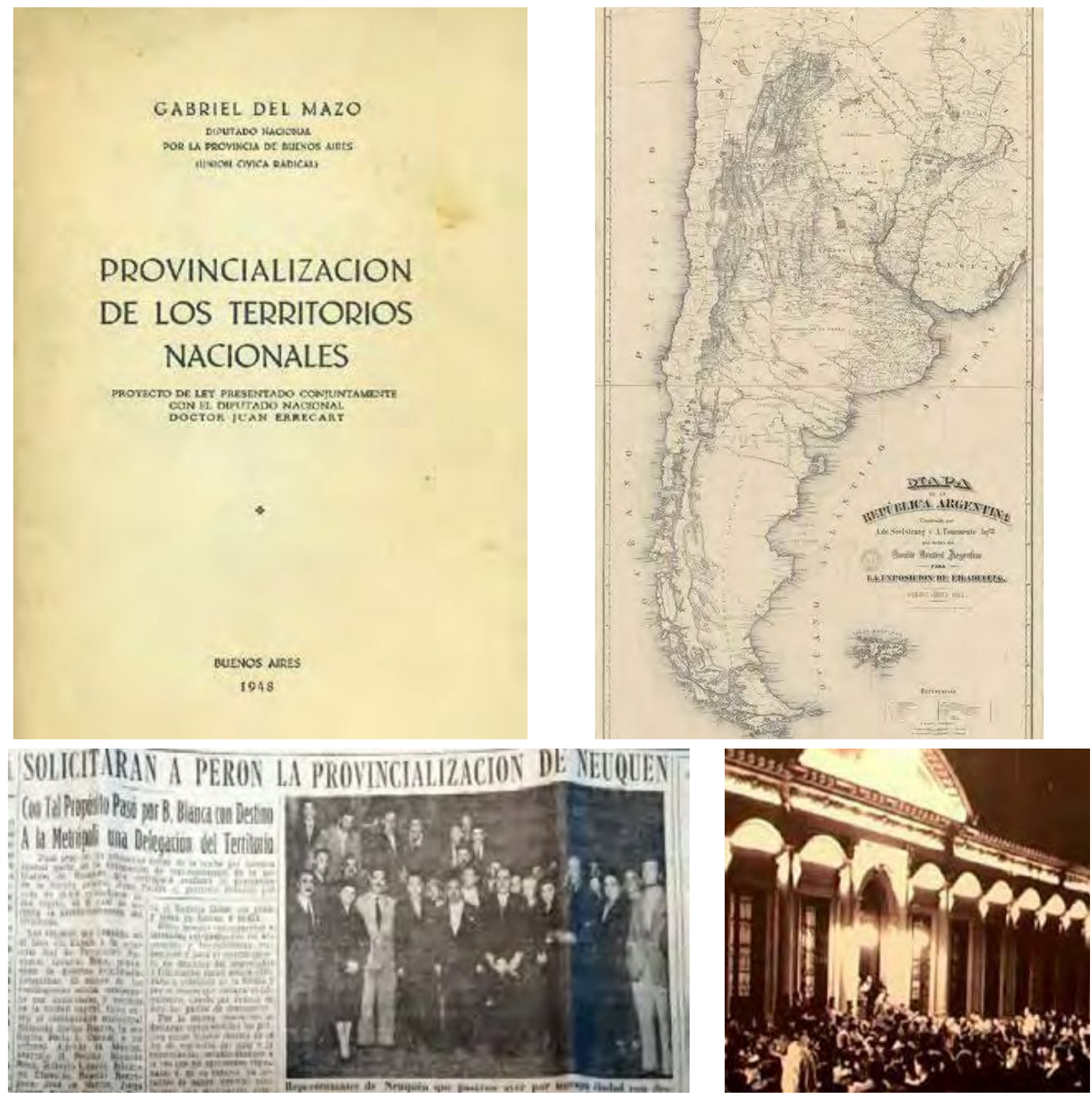

Imágenes: 13: Portada del proyecto de Ley para la Provincialización de los Territorios Nacionales. Presentación del diputado por la Unión Cívica Radical: Dr. Juan Errecart (1948). 14: Mapa realizado por Arthur Von Seelstrang y A. Tourmente del departamento de Ingeniería de la Nación. 1875.

15: Diarios de época, (1955). Foto de la repercusión y 16: Festejos ante la Efectivización de la Provincialización de Misiones. (1955) 


\section{Transformaciones geopolíticas}

\section{La provincialización de Misiones}

La provincialización de los territorios nacionales, ocurrida durante los primeros años de la década de 1950 , puso fin, por un lado a la larga etapa territorial signada por restricciones al ejercicio de la ciudadanía política para sus habitantes y los incorporaba con plenos derechos al Estado Nacional. ${ }^{33}$ Por otro, y de manera simultánea, clausuraba las desigualdades cívicas, los argumentos de inmadurez, esgrimidos por quienes sostenían la incapacidad de los habitantes de aquellos territorios para designar a sus representantes y autoridades ${ }^{34}$ y generaba la necesidad de nuevos programas arquitectónicos y los edificios que los contuviesen.

El 20 de julio de 1951 se formaliza la provincialización de La Pampa y Chaco mediante La Ley №14.037; el 22 de diciembre de 1953 la de Misiones por La Ley 14.294; y finalmente La Ley № 14.408 publicada en el Boletín Oficial el 15 de junio de 1955 creaba las provincias de Formosa, Neuquén, Río Negro, Chubut y Santa Cruz. Esto se da en el marco de la estrategia peronista de conservación del gobierno y aumento del padrón electoral, plasmado en el plan de incorporación de los territorios nacionales a la gran familia federal argentina. Sus derivaciones, tanto como las consecuencias de los planes y estrategias elaboradas para las nuevas provincias se continuarían más allá del derrocamiento del Gobierno del Presidente Perón, ocurrido en 1955.

\section{Ocupación, tutela y Territorio Nacional}

Misiones fue parte de diversas experiencias históricas: segmento del territorio guaraní; provincia jesuítica durante gran parte del período colonial, Gobernación de Misiones, luego de la expulsión de los jesuitas y la creación del Virreinato del Río de La Plata a fines del siglo XVIII. ${ }^{35}$

Iniciado el siglo XIX, durante la guerra de independencia colonial, la parte sur de Misiones fue objeto de disputas encabezadas por diferentes intereses y ejércitos; el Estado paraguayo, el Imperio brasileño, la provincia de Corrientes, las Provincias Unidas del Río de La Plata, más tarde la Confederación. En definitiva el espacio reconocido, posteriormente como Territorio Nacional de Misiones primero y Provincia de Misiones después, estuvo reclamado por la definición geo-política territorial y económica de los nuevos poderes regionales emergentes ${ }^{36} \mathrm{~A}$ poco de iniciarse la guerra de la Triple Alianza, en 1860, Paraguay cedió los territorios de Misiones que reivindicaba desde 1830 como propios, mediante la instalación de tropas militares, población y tráfico comercial. Al finalizar la guerra, la administración de la provincia de Corrientes quedó designada por el Estado Nacional para administrar estas tierras y sostener la integración al Estado argentino.

33 -RUFFINI, Martha (2005). Algunas reflexiones en torno a la provincialización. Revista Avances del Cesor, Año V, , N5. pp.132-148. 34 -Varios estudios e investigaciones dan cuenta del presente argumento, recopilados en Historiapolítica.com, sitio de estudio de Historia contemporánea, dirigida por ROMERO José Luis (http://historiapolitica.com/biblioteca/).

35 -SCHVORER, Esther Lucía (2008). "Misiones: Estructura Social Agraria, estado y conflictos sociales. Las circunstancias de una historiografía regional". En ROMERO Luis Alberto (dir) Historia Política.com: http://historiapolítica.com/biblioteca/. Recuperado $12 / 06 / 2014$

36 -SCHVORER, Esther Lucía (2008). “Misiones: Estructura Social Agraria...cit. 
Se inició una puja de fuerzas que por los intereses sobre los territorios de Misiones, enfrentó al Gobierno Central con el de Corrientes durante más de 40 años, transitando esta confrontación por diferentes escenarios con alternadas consecuencias. Este camino de desencuentros, enfrentamientos y operatorias poco transparentes conforma una matriz que tiene fuertes implicancias en el desarrollo territorial y condicionó la política colonizadora que el Estado Nacional pretendía llevar a cabo.Cuando en 1881 la federalización de los territorios de Misiones, resultaba un hecho inminente, la gobernación de Corrientes, que ejercía la tutela, acordó entregar la jurisdicción de estas tierras a la Nación, pero no su propiedad. ${ }^{37}$ Mientras en el Congreso de la Nación, se llevaban a cabo las discusiones sobre la federalización de Misiones, Corrientes vendió 2.025 .000 hectáreas sobre la base de mapas rudimentarios, inexactos y sin mensuras de tierras. ${ }^{38}$ De este modo, durante 1881, la casi totalidad de la superficie del Territorio Nacional de Misiones, se dividió entre treinta y ocho propietarios.

Con el traspaso de las tierras a la esfera nacional, Misiones se incorporaba a la estructura emergente del Estado Nación que tenía como necesidad fundamental, expandirse sistemáticamente en el territorio, por medio de una dominación expresada en formas de conquistar el poder simbólico y material, incorporando estos espacios al esquema político y económico, dentro del proceso de construcción de la identidad nacional. Este proceso estuvo signado por diversos pasos que se desarrollaron entre 1878 y 1885: el colonialismo interno de Buenos Aires, sobre los territorios interiores, expandiendo el Estado Nacional y consolidando la posición hegemónica de la oligarquía pampeana, la instauración del modelo agroexportador, el genocidio del indio, manifestado en la "Conquista del Desierto" operando el concepto de "espacio vacío", "espacio incivilizado", que permitió legitimar la política sistemática de exterminio y la ocupación "in arbitrio" como parte de una empresa civilizatoria, materializada en el corrimiento de las fronteras y la territorialización del aparato político-estatal, como expresión del proyecto liberal modernizante. ${ }^{39}$

La colonización de Misiones fue realizada sobre un territorio habitado, en el que se daban múltiples relaciones sociales y actividades económicas, numerosas investigaciones rompen con el mito de "espacio vacío" que la historiografía provincialista tejió, alineando su narrativa al paradigma de la historia nacional dominante. ${ }^{40} \mathrm{El}$ hecho, por tanto, de que el Estado Nacional, nombrara el $1^{\circ}$ de enero de 1882 a Rudecindo Roca, hermano del por entonces presidente de la Nación Julio Argentino Roca, como Gobernador del Territorio Nacional de Misiones, toma enorme relevancia.

Una vez instalada y organizada la administración nacional, comenzó la colonización oficial y privada. Durante 1890 una corriente inmigratoria proveniente de distintos lugares de Europa, (Polonia, Alemania, Suiza, Ucrania), conformó una matriz multiétnica. Las tierras que habían escapado de la venta fraudulenta realizada por el Gobierno de Corrientes, le permitió al Estado contar con tierras fiscales, donde comenzar a asentar las incipientes poblaciones, que tomaron dos tipologías como matriz espacial: la grilla en forma de damero, preferida por el aparato estatal y la Waldhufendörfer o asentamiento lineal para aquellos emprendimientos gestados por las empresas colonizadoras de tierras de propiedad privada. ${ }^{41}$

37 -"El gobernador de Corrientes Antonio Gallino, con el propósito de entregar al Gobierno Nacional, solamente la jurisdicción del territorio de Misiones, pero sin la propiedad, logró que la legislación correntina el día 12 de junio de 1881, sancionara la Ley de Tierras por la cual se autorizó a la Gobernación de Corrientes a enajenar las tierras misioneras a razón de lotes de 25 leguas cuadradas, es decir lotes de $\mathbf{6 7 . 5 0 0}$ hectáreas" ABINZANO, Roberto Carlos: (1985) Procesos de Integración en una sociedad multiétnica. Tesis Doctoral, Tomo I. Capítulo VI Universidad de Sevilla España. p.4.

38 -PEDRANZINI Maximiliano (2010). "Apuntes sobre la Provincialización de Misiones." En ROMERO, Luis Alberto (dir) Historia Política.com. p.5. Recuperado 15/07/2014.

39 -PEDRANZINI, Maximiliano (2010). “Apuntes sobre la Provincialización de Misiones”...cit.p.7.

40 -SCHVORER, Esther Lucía (2008). "Misiones: Estructura Social Agraria”...cit.p.7.

41 -SCHVORER, Esther Lucía (2008). “Misiones: Estructura Social Agraria”...cit.p.15. 
El proceso de colonización llevado a cabo en Misiones, contó, por tanto, con una matriz mixta; una efectuadapor el Estado, que se sostuvo legitimando los asentamientos espontáneos en tierras fiscales y aquellas extensiones vacantes, desafectadas de las ventas masivas: así se originaron las colonias de Candelaria, Santa Ana, San Carlos, San Javier, San Ignacio y Apóstoles hacia 1883, mientras que Aristóbulo del Valle (1908) y Manuel Belgrano (1921) surgieron a partir de la recuperación de tierras ${ }^{42}$. Otra fue la que se originó a partir de la iniciativa privada: Adolfo Schwelm inició uno de los más vastos emprendimientos, mediante la fundación de Eldorado (1919) promocionado en Europa por la compañía que llevaba el mismo nombre, que contaba además, con agentes en el puerto de Buenos Aires para trasladar a los inmigrantes hasta la nueva colonia. Carlos Culmey, por su parte, fundó las colonias de Puerto Rico y Monte Carlos hacia 1920. Más tarde se fundarían Alba Posse, y el Soberbio hacia 1940. Todos estos departamentos serán clave en el desarrollo de la tesis.

\section{De Territorio Nacional a Provincia}

En 1919, durante el gobierno de Hipólito Yrigoyen (1916/1922) se elevó al Congreso de la Nación el proyecto de provincialización, que buscaba convertir tanto a Misiones como a los demás territorios nacionales en provincias. La falta de mayoría, con la que contaba el oficialismo en el Congreso y los intereses de los propietarios, representados por los partidos opositores, impidió que se concretara. Poco después, fue presentado un proyecto de ley por un grupo de diputados correntinos que proponían se reintegrase al territorio de la provincia de Corrientes la zona ocupada por la Gobernación Nacional de Misiones. ${ }^{43}$

El grado de provincia se logró, para la casi totalidad de los territorios nacionales durante el segundo gobierno de Perón (1952/1955)44. La provincialización del territorio nacional de Misiones constituyó un proceso de integración política, si bien impulsado por el peronismo, resultó de la confluencia de voluntades puestas de manifiesto en movimientos territoriales y en asambleas que se realizaron previamente ${ }^{45}$. Aunque es innegable que durante el gobierno peronista se llevó a cabo un proceso de integración política e institucional para federalizar los territorios nacionales y colocarlos en condiciones de igualdad con las demás provincias. ${ }^{46}$ El 22 de diciembre de 1953 la Ley 14.294 marcó definitivamente el destino de muchos territorios nacionales que pasaron a convertirse en provincias. Misiones se incorporó rápidamente a las coordenadas ideológicas del peronismo, en el afán de adquirir en primera instancia el grado jurídicoinstitucional de provincia y en segundo término acceder a la posibilidad de ejercer la participación política y la consiguiente construcción inmediata del "ciudadano misionero". ${ }^{47}$

42 -GALLERO, María Cecilia; KRAUSTSTOFL Elena (2009). Proceso de poblamiento y migraciones en la Provincia de Misiones, Argentina (1881-1970). En: Revista de Antropología. AVÁ, №16. pp. 249-263.

43 -PEDRANZINI Maximiliano (2010). "Apuntes sobre la Provincialización de Misiones"...cit.p.10. (El primer proyecto de provincialización de Misiones fue llevado a cabo por el yrigoyenismo, el cual está fechado el 19 de agosto de 1919 y se ubica en el expediente $N^{\circ} 53$ de la Cámara de Diputados del Congreso de la Nación, presentado por Hipólito Yrigoyen, ingresando como proyecto de ley № 2 en la $31^{\circ}$ sesión ordinaria el 20 de agosto de ese año. En el proyecto se señalaba que Misiones había superado el número de habitantes exigido por el artículo $4^{\circ}$ de la ley № 1532 de Organización de los Territorios Nacionales. Pero el proyecto elevado al Congreso de la Nación no contemplaba todos los datos estadísticos y demográficos correspondientes para corroborar dicho proyecto. Congreso de la Nación, Diario de Sesiones de la Honorable Cámara de Diputados, Sesión del 20 de agosto de 1919. Tomo III, p. 675, citado en QUARANTA de ERRECABORDE, Ana María (1987). Historia de la Provincialización de Misiones. Posadas .Misiones. Ediciones Montoya.p.146.

44 -RUFFINI Martha (2005). "Peronismo, territorios nacionales y ciudadanía política. Algunas reflexiones en torno a la provincialización”. En: Revista avances del CESOR, año V n 5 Rosario. pp.132-148.

45.-RAFFAELE Ana Clara (2012) La construcción de políticas durante el proceso de provincialización del Territorio Nacional de Chubut: 1954-1955 [en línea]. Trabajo final de grado. Universidad Nacional de La Plata. Facultad de Humanidades y Ciencias de la Educación. Disponible en: http://www.memoria.fahce.unlp.edu.ar/tesis/te.754/te.754.pdf

46 -PEDRANZINI Maximiliano (2010). "Apuntes sobre la Provincialización de Misiones”...cit.p.18.

47 -PEDRANZINI Maximiliano (2010). "Apuntes sobre la Provincialización de Misiones"...cit.p.19. 15/07/2014, de El concepto de ciudadano misionero refiere a la representatividad que los pobladores adquieren a partir del derecho al voto, pudiendo elegir, además de sus gobernantes, a sus representantes en el Congreso de la Nación. La cantidad de diputados nacionales, que cada provincia aporta, está en estrecha relación a su población, así por ejemplo Buenos Aires cuenta con setenta diputados Santa Fe dieciocho, Córdoba trece y Chubut cuatro, por citar algunos casos, mientras que los senadores son tres por cada provincia. 


\section{Luego de la provincialización}

La organización de la moderna provincia de Misiones, entendiendo por "moderna" la formación territorial y socioeconómica que fue incorporada al Estado nacional argentino en 1953, requirió la rectificación de la ciudad de Posadas como capital ${ }^{48}$, así como la organización institucional e inicio del funcionamiento de la estructura del Estado provincial. ${ }^{49}$ La puesta en vigencia de la Ley 14.294 establecía la obligatoriedad de conformar una Convención Constituyente, convocada por el Poder Ejecutivo Nacional, estableciéndose una mesa directiva de carácter provisorio, que designó con el cargo de Presidente, al doctor López Forestier, y Julián Szychowski, para que ocupe el puesto de secretario el 8 de noviembre de $1954^{50}$. La Convención, debía regular la conformación del nuevo Estado y proponer políticas para su desarrollo.

Dentro de este marco de organización de un nuevo Estado provincial, el 16 de septiembre de 1955, la autoproclamada "Revolución libertadora" derrocó al gobierno de Perón. El General de División Lonardi, líder de la sublevación militar, asumió el poder y ocupó la presidencia de la Nación. Fue designado Adolfo Pomar, como nuevo interventor de la Provincia de Misiones, quien implementó un plan de obras a gran escala.

Esta operatoria fue en realidad la continuación del 2do Plan Quinquenal que el gobierno anterior había previsto para desarrollar entre 1952 y 1957 y abarcaba un espectro muy amplio de obras que se concentraban en tres grandes áreas: equipamiento energético, vial y arquitectónico. $Y$ desarrollar los siguientes temas y objetivos:Trabajo. El estado como promotor de la plena ocupación, promoviendo la intensificación de la producción para ponerla al servicio de los objetivos del Plan. Conseguir una distribución racional en todo el territorio nacional del volumen de las obras públicas. Salud Pública. Se buscaba aumentar un $43 \%$ la capacidad hospitalaria. Distintas modalidades para satisfacer la necesidad de viviendas y reducir el creciente déficit de las mismas. Promover la Industria de la Construcción, dando apoyo del Estado para elevar su capacidad técnica y financiera. Proponer un régimen crediticio para la obtención o construcción de viviendas .Turismo. El Estado Nacional buscaba invertir en la construcción de Hoteles y Hosterías por una suma total de 20.000.000 \$.- según consta en el Capítulo denominado: Inversiones del Estado, dentro del reglamento del 2do Plan Quinquenal. ${ }^{51}$

Forestación y Explotación de maderas: Favorecer la producción para abastecer la demanda originada por la construcción. Se buscaba conseguir el autoabastecimiento en materia energética, tanto en lo que refería a combustibles fósiles, como a la construcción de obras para la generación de energía eléctrica. Se realizarían obras hidráulicas, a través de cinco embalses de aprovechamiento múltiple. La ampliación de la red ferroviaria, caminera, las construcciones portuarias y el tendido de la red sanitaria completaban el segmento de infraestructura previsto en el Plan. Se destinaban los siguientes montos a su concreción: 33.500 millones de pesos, discriminando 30.500 millones de pesos al Plan Nacional y 3.000 millones de pesos a los Planes provinciales. ${ }^{52}$

48 -Originalmente la capital elegida para el Territorio Nacional de Misiones, fue Corpus, designada mediante la Ley del 22 de diciembre de 1881 sancionada por Julio Argentino Roca. Posadas en ese momento quedaba incluida en el territorio de Corrientes. En 1953, Corrientes cede Posadas para que se constituya en capital de la nueva Provincia.

49 -SCHVORER Esther Lucía (2008). “Misiones: Estructura Social Agraria”...cit. p.12.

50 -Diario de Sesiones de la Convención Constituyente de Misiones. Año 1954; 8 de Noviembre/21 de noviembre. Debates y Sanciones. Provincia de Misiones. Casa de Gobierno. p.15.

51 -CÁMARA ARGENTINA DE LA CONSTRUCCIÓN (1952). “2do Plan Quinquenal”. Revista Construcciones, Año 8 N91, 3-95.

52 -CÁMARA ARGENTINA DE LA CONSTRUCCIÓN. (1952). 2do Plan Quinquenal. Revista Construcciones, Año 8 N91, 3-95. 
El Plan no fue abandonado pese al cambio de gobierno y buscaba resolver antiguas demandas realizadas por la Administración Provincial, largamente postergadas. La empresa colonizadora, que llevó a cabo el Estado, tuvo dos ejes de desarrollo; una territorial y otra cultural, expresada en la construcción de escuelas como agentes de la "argentinización" de los pobladores. A pesar de la importancia que se le asignaba al sistema educativo, como eje de la formación pedagógica del ciudadano y su incorporación a las coordenadas nacionales, resultaba insuficiente.

Esto puede corroborarse en la siguiente carta remitida al Gobierno Nacional, escrita por el entonces gobernador Julio Agustín Vanasco:

..."Preocupa a este Gobierno la construcción de Edificios para la Escuela Normal. La falta de capacidad y las pésimas condiciones higiénicas y pedagógicas, hacen de urgencia la solución de este asunto. Basta recordar que ochenta niñas cursan sus estudios en Villa Encarnación (Paraguay) para comprender la urgencia del problema planteado." 53

Así el Plan pensado para Misiones, se alineaba, por un lado con demandas largamente dilatadas, pero por otro con aspiraciones que el Gobierno Nacional ideaba para la nueva provincia y el rol que se esperaba ocupase dentro del nuevo escenario. ${ }^{54}$ En este marco, surgen, los concursos convocados para la construcción de Escuelas, Hospitales, Comisarías, Hoteles y Hosterías entre 1956 y 1957. 

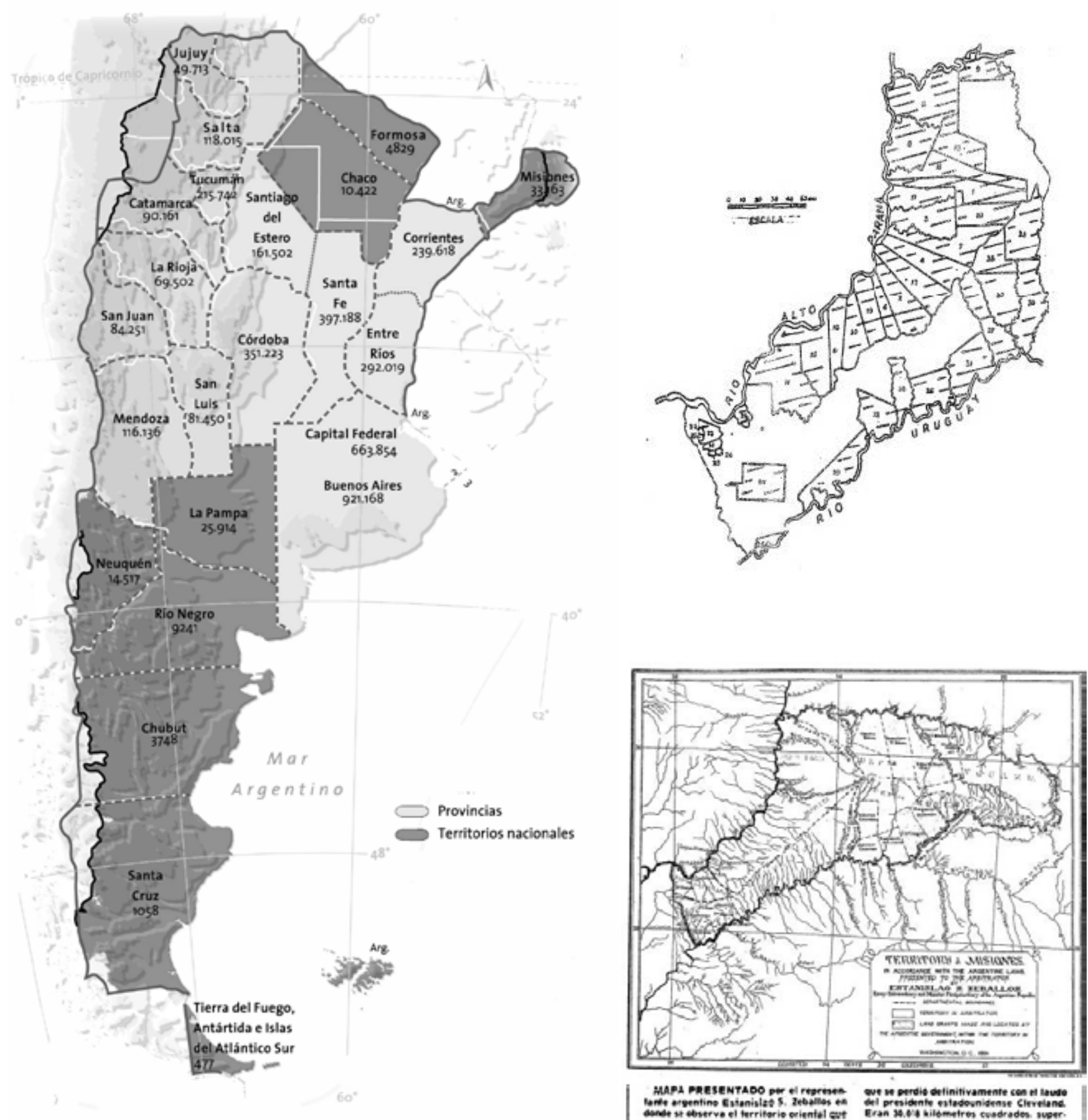

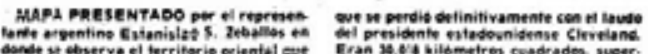

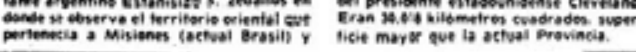

Imagen: 17: Mapa de la Argentina (1950) antes de la provicializción de los Territorios Nacionales; Imagen 18: Mapa de la venta efectuada por Corrientes de los territorios misioneros, antes del traspaso a la Nación (1881).

Imagen 19: Antecedentes territoriales, Antes del Laudo de Cleveland (1888) donde Argentina perdiera el extremo oriental de la actual Provincia de Misiones, en beneficio del Brasil. 


\section{Puesta en marcha del Plan}

El 11 de mayo de 1956 la Asociación de Profesionales de la Ingeniería y la Arquitectura de la Provincia de Misiones, remite a la Sociedad Central de Arquitectos el decreto provincial $N^{\circ} 548$ donde se designa a esa institución para organizar los concursos de anteproyectos incluidos en el Plan de Obras Públicas. La organización de los concursos se llevó a cabo centralizando en Misiones todas las tareas administrativas, organizativas y de fiscalización, necesarias.

Este fue uno de los mayores operativos realizados en el interior del país, que incluía tanto los de estudios urbanísticos, concursados por antecedentes, como los anteproyectos de los diferentes edificios; de carácter nacional, adjudicando a los ganadores la dirección de las obras. ${ }^{55}$

Los Concursos se dividieron en tres áreas:

1era: Estudios Urbanísticos de la Provincia de Misiones y Anteproyecto de Ordenamiento para la Ciudad de Posadas.

2da: Edificios en el territorio de la Provincia, integrados por cuatro Escuelas Urbanas de 7 aulas, un hospital de 120 camas, dos hospitales de 30 camas, cuatro unidades sanitarias, una cámara frigorífica, tres hoteles de turismo, siete hosterías y cinco comisarías.

3era: Edificios en la ciudad de Posadas: Ministerio de Economía, Dirección de Servicios Generales, Tribunales de la Provincia, Instituto Tecnológico, un barrio de viviendas, una escuela de 14 aulas, un matadero modelo y dos mercados.

Del plan previsto, se ejecutaron los Concursos de planeamiento y los de arquitectura, principalmente aquellos que se localizaban en el interior de la provincia. Todos ellos permitieron efectivizar y hacer visible la renovación generacional con la aparición de nuevos actores en la producción arquitectónica nacional ${ }^{56}$. El Grupo URBIS, conformado por José Luis Bacigalupo, Alfredo Luis Guidali, Juan Kurchan, Jorge Osvaldo Riopedre, Héctor Ugarte, Simón L. Ungar y un grupo de asesores, entre los cuales se destacaba el de sociología, el Dr. Gino Germani, obtuvo el primer premio para elaborar el Plan Regulador de la Ciudad de Posadas en el año 1957. Este Plan formaba parte de uno de mayor alcance, que pensado para la Provincia entera, buscaba desplegar aspectos económicos y urbanos para toda Misiones. Y al mismo tiempo ponía en sintonía al proyecto con los ideales desarrollistas propugnados y materializados, por esos años en gran parte de América Latina. Efectivamente la ocupación y urbanización de los territorios interiores era, en ese momento, una búsqueda central de los gobiernos de la región, basta mencionar el caso de Brasilia, ocurrida durante los mismos años, para ofrecer un panorama en donde estas experiencias no resultaban hechos aislados y se constituían como empresas signadas por el espíritu de la modernidad, en el sentido de realizar gestas heroicas, de enorme carga simbólica, buscando trasladar la "civilización" a la selva ${ }^{57}$,

55 -Si se toman las obras concursadas durante el período de tres años 1956/57/58 se contabilizan 45 grandes concursos, mientras que los 10 años existentes entre 1945 y 1955 apenas registran 35. Fuente: SCHERE, Rolando (2008). "1956/1975". En Concursos 1825/2006. Buenos Aires.Sociedad Central De Arquitectos.p.259

56 -SCHERE, Rolando (2008). “Índice general”. En Concursos 1825/2006...cit.pp.801-802.

57 -Conferencia de Adrián Gorelik (7-16 agosto de 2014) en la Universidad Nacional de La Plata, en el marco del ciclo: El pensamiento sobre "la ciudad latinoamericana" 1940/1975. Buenos Aires Argentina 
produciendo lo que Fernando Aliata denominó: los nuevos monumentos patrióticos ${ }^{58}$, materializados en grandes obras de infraestructura territorial. Es un momento en el que se establece un pasaje típicamente voluntarista que propone resolver a través de un salto tecnológico una fractura que es en verdad política y cultural. ${ }^{59}$, tiempo de total aceptación y confianza en el "Plan" y su concepción moderna (asociada con proyecto, plano y programa) cuando proyecto, plan y programa se entendieron como acciones similares y convergentes de síntesis y previsión, con lo que se manifestaba la decisión y la presunción de control sobre las interpelaciones humanas, la afirmación de la voluntad consciente y el rigor racional. La idea de plan se aproximaba a la de tabla rasa, opuesta a la tradición y a la construcción existente ${ }^{60}$ y suponía el total dominio de las variables sobre las que el plan operaría, a partir de la voluntad de los técnicos que lo diseñaban, ideales claramente expuestos por Jorge Enrique Hardoy ${ }^{61}$ :

"la función integradora y el valor simbólico de Brasilia para el Brasil, el impacto geopolítico de la carretera de la selva para Perú, las grandes rutas que unen el interior de Paraguay y Bolivia, con los puertos de Argentina y Brasil, la ruta Panamericana, los grandes proyectos hidroeléctricos, la concepción regional de Venezuela afirmando la vigencia de un nuevo gran polo de desarrollo en su Guayana, demuestran que América Latina está avanzando hacia sus propias fronteras. Y nuevos centros de vida y un esquema de urbanización complementario al existente sin duda, surgirán como expresión de una nueva América Latina que se desprenda de los límites del pasado y busque en la idea de integración la expresión de su modernización".

Había un largo camino por delante, durante el inicio de estos proyectos, Misiones contaba apenas, con solo $14 \mathrm{~km}$ de rutas asfaltadas ${ }^{62}$.

\section{Plan para la Provincia de Misiones:}

\section{EI Plan URBIS}

Dos de los integrantes del grupo Urbis, los arquitectos Juan Kurchan y Simón L. Ungar habían formado parte desde los inicios del grupo Austral, ocurrido entre septiembre y octubre de 1937 y que había buscado la articulación entre arquitectura moderna y urbanística, participando en distintas experiencias en el ámbito nacional: desarrollo del Plan para Buenos Aires, durante los años 1937 y 1938, participación en el Concurso Nacional de la Ciudad de Mendoza de octubre de 1939; integrantes de la Comisión Sanjuanina Pro-Restauración Provincial (CSPRP) de 1944 y finalmente directivos del Estudio del Plan de Buenos Aires (EPBA) en $1949 .{ }^{63}$ Es interesante pensar al plan como la exteriorización del proyecto de "unidad nacional" que las políticas de incorporación de estas tierras, en su condición determinaba para la conformación argentina, en tensión con las reglas del juego que el período de posguerra de la economía internacional,

58 -Aliata Fernando (1999). "Comentario" ALTAMIRANO, Carlos (ed.) La Argentina en el siglo XX. Buenos Aires. Ariel. Citado por GORELIK, Adrián (2013) Miradas sobre Buenos Aires: Historia Cultural y Crítica urbana. Buenos Aires. Siglo Veintiuno Editores. p.66.

59 -GORELIK, Adrián (2008). Buenos Aires en el país (para una historia cultural de las imaginaciones territoriales). En Miradas sobre Buenos Aires. Historia cultural y crítica urbana...cit. pp.18-68.

60 -Voz "Plan". En LIERNUR, Jorge Francisco; ALIATA, Fernando (comp) (2004) Diccionario de la Arquitectura en Argentina: Voz: Plan. Tomo O-R. p. 75

61 -GORELIK, Adrián (2008). "Buenos Aires en el país..." cit. pp.18-68.

62 -MINISTERIO DE ECONOMÍA Y OBRAS PÚBLICAS DE LA PROVINCIA DE MISIONES (1956)Antecedentes Plan Estratégico. Diagnóstico y Situación Actual. Misiones.

63 -LIERNUR, Jorge Francisco; PSCHEPIURCA, Pablo (2008). "El grupo Austral: acciones e ideas para la construcción de una vanguardia". En La red Austral, Obras y Proyectos de Le Corbusier y sus discípulos en la Argentina 1924/1965. Quilmes. Prometeo. pp.219-240. 
había impuesto para la nueva configuración geopolítica del mundo. Y por otra parte como la integración, de un modo particular, de corrientes del pensamiento urbanístico de distintas filiaciones, que produjeron dentro del ámbito local una interesante reformulación y propuesta de un cuerpo teórico, que puso en crisis la idea de América Latina como mera reproductora de ideas surgidas de los centros de irradiación de cultura ${ }^{64}$.

Gorelik (2008) señala tres etapas en la configuración social de la ciudad en el contexto latinoamericano: una primera etapa ligada a la voluntad de construcción de nación y una identidad que la contenga; una segunda, vinculada a la emergencia de las ciencias sociales y la creencia en que el progreso y el desarrollo podían alcanzarse siguiendo las directrices de la planificación técnica y una etapa final vinculada al ánimo anti-urbano coincidente con la pérdida de confianza en las teorías de la modernización ${ }^{65}$. En la transición entre las dos primeras configuraciones, se ubica la propuesta del Plan Regulador. ${ }^{66}$

\section{"Región, provincias y democracia"}

Un debate reciente propone la existencia de una corriente del pensamiento que produjo, en el ámbito local, una síntesis entre ideas casi antagónicas. Efectivamente, investigadores que se han ocupado del tema en Misiones, como el caso de María del Rosario Millán (2009), en varios escritos para la Universidad Nacional de Misiones sostiene, en un estudio sobre el Plan Urbis que "autores como F. Choay ${ }^{67}$ describen al regionalismo de Lewis Mumford como la corriente crítica al modelo progresista del urbanismo clásico. Esta corriente de orientación humanista, proponía la revisión de los postulados metodológicos y apuntaba a flexibilizar los rígidos principios de ordenación y normativa urbanística, pudiendo ordenar a sus tres grandes ejes en relación naturaleza- medio urbano. La continuidad histórica social y geográfica. El principio de limitación."

Mumford sostenía que se debía conformar una red regional que diera forma a las actividades económicas y culturales. ${ }^{68}$ Se oponía al pensamiento progresista y abogaba por el mantenimiento de la tradición cultural, una mayor integración de la naturaleza con el medio urbano dada por la estructuración de los espacios verdes en función de los edificios. Mumford en su libro "The Culture of the Cities" (1938) realiza la actualización del esquema operativo de Patrick Geddes, quien había descrito en su diagrama la evolución de la ciudad como una curva ascendente que partiendo desde la polis, culminaba en la metrópolis, para descender desde ese punto a la megalópolis, la que corroída por su propio crecimiento excesivo terminaba en la necrópolis. Este rumbo podía, según la actualización sugerida por Mumford corregirse, si se establecían los fundamentos sociales para la reconstrucción urbana en escala regional. ${ }^{69}$ Estos enfoques tuvieron una rápida difusión en América Latina. Sus textos junto con las traducciones del alemán de los textos de George Simmel, y las ideas de Spengler, de temprana difusión en la Argentina (por ejemplo el número 3 de la revista Sur, en 1931, publica un largo artículo suyo, que resume los argumentos del libro que estaba siendo editado ese año); sus teorías regionalistas y de la "planificación democrática" desarrolladas en Technics and Civilizations (1934) y The Culture of the Cities (1938), la difusión exitosa del New Deal rooseveltiano y los emprendimientos

64 -Son muchas las referencias que de este tema hace Liernur, se puede iniciar un abordaje en: LIERNUR, Jorge Francisco(2008). "Para una crítica desde América Latina: Repensando algunas ideas de Manfredo" . En "Trazas de Futuro”...cit. pp.21-53.

65 -ALTAMIRANO, Carlos (2002) Sociologías de la cultura. Buenos Aires Argentina. Ed. Paidós.

66 -MILLÁN María del Rosario (2009). Región Provincia, Capital. Identidades Locales y Discurso Urbanístico. En: Revista de estudios Digitales , №22, pp.32-49.

67 -CHOAY, Francoise (1970). El urbanismo. Utopías y realidades. Barcelona. Ed. Lumen.

68 -MUMFORD, Lewis (1969). “Disolución de la Megalópolis frente a la Integración regional”. En: Perspectivas Urbanas Buenos Aires. Emecé Editores. p.239.

69 -MUMFORD, Lewis (1969). “Epílogo: Alternativas que se nos presentan” En: Perspectivas Urbanas...cit. 9.321. 
como la planificación del Valle del Tennessee, de enorme impacto internacional, ${ }^{70}$ organizaron la forma en que se pensó el binomio territorio-ciudad en relación con las culturas nacionales. Y en ese sentido, la planificación urbana se constituyó como uno más de los discursos capaces de construir representaciones colectivas de la idea de nación. Liernur (2011), por su parte, señala que la experiencia del Tennessee Valley Authority (TVA) para los miembros del grupo Austral, que como hemos dicho anteriormente estaba integrado, entre otros por Kurchan y Ungar, imbuidos de la ilusión modernista de organización racional de la acción humana sobre la naturaleza, se presentaba como un ejemplo excepcional del poder del que dispone la arquitectura para mejorar la condición del hombre y como epitome activa de las ideas iluministas y de aspiración democrática. Es preciso aclarar en este punto, que las acciones del TVA, habían tenido amplia difusión en The Architectural Review durante 1929. ${ }^{71}$

Dentro de este debate Gorelik (2011) sostiene que surge el 'regionalismo humanista', corriente local que se apropió de las ideas del regionalismo planificador de Lewis Mumford, en especial de sus conceptos de descentralización y de 'planificación democrática'. Región y democracia entonces, constituían el binomio conceptual con el que los discursos estatales elaboraron las representaciones simbólicas del territorio para la Nación Argentina. Para los adherentes al regionalismo humanista, la noción de región tal como era abordada por Mumford -una realidad social, una unidad (geográfica, histórica, económica y cultural)cuadraba con una política tendiente a buscar el equilibrio entre las partes componentes de la 'república'. Así los simpatizantes del "regionalismo humanista"72 asociaron la definición "mumfordiana" de región, con las realidades físico-históricas de las provincias. Y esto se dio en la medida en que la apropiación de tales ideas respondió a la necesidad de construir discursos articuladores de una experiencia nacional y provincial. El surgimiento de figuras como las de Jorge Kalnay, uno de los protagonistas del debate urbanístico en la década de 1930 y uno de los principales promotores del primer congreso de Planificación Integral del Noroeste Argentino (PINOA), interlocutor principal del urbanista alemán Werner Hegemann ${ }^{73}$ y organizador, junto a otros del Primer Congreso Argentino de Urbanismo de 1935, o figuras como José María Pastor, central en la introducción de las corrientes "humanistas" del pensamiento anglosajón, o Canal Feijóo como principal opositor y reformulador de las ideas de Martínez Estrada, deben ser tenidos en cuenta para terminar de establecer una panorámica en donde ubicar a los diversos actores y a sus debates, que sirvieron de base para el desarrollo de las ideas de planificación, de la que el Plan Urbis forma, indudablemente, parte.

Estos primeros análisis, aportan un interesante acercamiento al debate acerca de las experiencias en planificación en el interior del país, durante finales de los años 40 y mediados de los 50, aunque, en el caso particular de los primeros estudios realizados sobre las experiencias del grupo de Kurchan, en el denominado Plan Urbis, se puede sostener que proceden de una mirada extemporánea de las ideas del CIAM (Congreso Internacional de Arquitectura Moderna), congelando su posición en los postulados surgidos de la Carta de Atenas (1933), sin tener en cuenta las profundas críticas, que dentro del seno del propio CIAM, se estaban produciendo. Es interesante traer a este punto las principales conclusiones surgidas durante el VIII Congreso del CIAM en julio de 1951 y el libro que las compila: El corazón de la Ciudad, por una vida más humana de la comunidad (E. N. Rogers, J. L. Sert y J. Tyrwhitt, 1955). Sin embargo todas estas reformulaciones no fueron incluidas en la bibliografía y las notas que integran el plan y sí las consignadas dentro de la Carta de Atenas. ${ }^{74} \mathrm{Al}$ mismo tiempo que gran parte del Plan para Posadas se

70 -GORELIK, Adrián (2013) Miradas sobre Buenos Aires...cit.pp.58-59.

71-LIERNUR, Jorge Francisco; PSCHEPIURCA, Pablo (2008) “La red Austral”...cit.p.323.

72 -GORELIK, ADRIÁN (2011). "Políticas de la representación urbana: el momento situacionista, en Buenos Aires". En: GORELIK, Adrián, Correspondencias...cit.pp.65-89.

73 -Para una mayor profundización sobre la presencia de Werner Hegemann, LIERNUR, Jorge Francisco (2008)."Un nuevo mundo para el espíritu nuevo"...cit.

74 -PROVINCIA DE MISIONES, MINISTERIO DE ECONOMÍA Y OBRAS PÚBLICAS (1957) Anteproyecto Plan Regulador: Compendio del Informe. Grupo Urbis Apartado: Noticias Bibliográficas. 
estableció sobre la división de las tan sostenidas "cuatro funciones vitales". ${ }^{75}$ Es preciso remarcar en este punto, que los años cincuenta, fueron años de revisión de los fundamentos volcados en la Carta de Atenas ${ }^{76}$ , de crítica a la rígida división de funciones y al anonimato producido por la pérdida de las señales históricas de la ciudad. Se inició entonces un proceso de reivindicación de las cualidades urbanas tradicionales que se habían despreciado en bloque, como la vida bulliciosa favorecida por la vieja "calle corredor" y sus diferentes escalas de espacios urbanos, en un intento explícito por volver a comprender el fenómeno de la ciudad, desde el interior de las visiones modernistas, superando la simplificación programática de entreguerras ${ }^{77}$. Basta con recordar el debate que se realizó en el invierno de 1958, en el que Aldo Van Eyck apuntó de manera explícita los inconvenientes que se habían generado a partir de la masiva reconstrucción europea según los parámetros del $\mathrm{CIAM}^{78}$.

Sin poder trazar en este punto la gravitación real de algunos de sus autores en el cambio de mirada que por la época tuvieron las teorías de la planificación, el traslado y presencia del italiano Ernesto Nathan Rogers ${ }^{79}$, uno de sus autores, en la Universidad Nacional de Tucumán, durante esos años, debiera ser tenida en cuenta. Efectivamente durante el período comprendido entre los años 1947 y 1951, fueron contratados, se radicaron o dictaron clases, proyectaron o publicaron trabajos inéditos, entre otros: Pier Luigi Nervi; los estudios de Planificación Regional, por citar un caso, de Cino Calcaprina realizados para la Universidad de Tucumán, formaron parte de la bibliografía de consulta del Plan; Enrico Tedeschi; Alberto Lapadula, Luigi Piccinato, Bruno Zevi y como se ha mencionado, Rogers. ${ }^{80}$ Todos ellos nucleados en torno a Jorge Vivanco quien mantenía estrecha relación con los ahora integrantes del grupo URBIS. Por otra parte E. Rogers se incorporó al EPBA durante el verano de 1949 y dentro del mismo período pronunció una serie de conferencias en donde instaba a no cortar lazos con la tradición. ${ }^{81}$

Vivanco, luego del plan para Mendoza, pensaba a la Argentina desde el interior del país, como a unas líneas de fuerzas naturales y productivas que no pasaban por el centro histórico tradicional. Los problemas de Buenos Aires, sostenía, no se resuelven con planes de mejoramiento local sino con la reestructuración a nivel nacional, de las fuerzas que provocaban su hipertrofia y su expansión. Todos estos pensamientos se entrecruzan con los vertidos por Canal Feijóo y participan del mismo espíritu cuando sostiene que "la extensión no es el mal de la república, sino apenas el síntoma del verdadero mal: la incapacidad del alma argentina por asumir un sentimiento patriótico de la totalidad territorial, proponiendo la ubicación de ciudades en el interior para lograr un programa de recuperación geográfica. ${ }^{82}$

La participación de ambos en los Congresos del PINOA, adquiere particular relevancia. Otro dato central en la formación de este cuerpo de ideas, lo constituye la presencia de Gino Germani, dentro del grupo Urbis como asesor en el campo de la sociología. Gino Germani fue un gran protagonista en la consolidación de la sociología urbana en el ámbito universitario nacional. En los años cincuenta ya había formulado parte de sus críticas a la teoría desarrollista, tanto por su carga normativa como por cierta inclinación funcionalista. Había participado en Estados Unidos de la revolución que en el campo de las Ciencias Sociales, se estaba produciendo, trayendo al debate local esas reformulaciones. Por tanto el Plan para Posadas, permite trazar

75 -Ver Anexo. Memoria de los autores para el Plan de Posadas. (imág.4 a 17). pp.4 -5.

76 -El texto de 1943, surgido de la reunión de los Congresos Internacionales de Arquitectura Moderna, realizados en Atenas

diez años antes, cuando se fijaron las pautas de un modelo de ciudad modernista

77 -GORELIK, Adrián (2004) Miradas sobre Buenos Aires...cit. p.178.

78 -LIERNUR, Jorge Francisco (2008): “Trazas de Futuro"...cit.p.51.

79 -Ernesto Nathan Rogers, diseñador de la Torre Velasca, en Milán en 1956, fue director de las revistas de arquitectura Domus (1946 - 1947) y Casabella (1953 - 1965)

80 -WAISMAN Marina; GUTIERREZ Ramón; NICOLINI, Alberto; ORTIZ Federico; DE PAULA, Alberto (1980), "Documentos para una historia de la arquitectura argentina". Summa $N^{\circ} 7$ (Nacionalismo Popular 1943/1955). Buenos Aires.

81 -LIERNUR, Jorge Francisco; PSCHEPIURCA, Pablo (2008). La red Austral...cit.p.323

82 -GORELIK, Adrián. (2004) Miradas sobre Buenos Aires...cit.p.48. 
el vasto escenario, donde ocurría el debate que sobre el urbanismo, se daba durante los primeros años de 1950, puesto en tensión con la realidad política nacional, atravesada por la llamada "revolución libertadora", proscribiendo al peronismo y dando paso al condicionado gobierno democrático de Arturo Frondizi.

Es interesante ubicar al Plan Urbis para Misiones y Posadas en el cruce de la revisión crítica de los primeros fundamentos del CIAM, la transformación que se estaban produciendo en el campo de las Ciencias Sociales y la particular mirada de los actores que participaron en su ideación, que fueron demostrando un paulatino cambio de sus teorías y posicionamientos a lo largo de sucesivas experiencias en sintonía con revisiones que dentro del mismo campo, se daban de manera simultánea en otras latitudes. La Propuesta del Plan desarrollado por el grupo Urbis, se alineó con la larga tradición que buscaba mediante la materialización de espacios cívicos y edificios simbólicos representativos llevar y hacer visible la presencia del Estado. Muchos de los programas construidos no se conformaron únicamente por palacios gubernamentales o sedes de algunos de los poderes estatales; escuelas, comisarías, hospitales, hoteles, plazas, puertos, conformaban una multiplicidad de temas utilizados por el Estado para concretar su representación y de ese modo hacer "visible" su presencia.

En este sentido las escuelas cumplían con un doble objetivo, por un lado expresaban exteriormente el destino del edificio, manteniendo aquella tradición de saberes clásica, en la que un edificio debía representar aquello para lo que estaba construido y mediante la mejor adaptación de la idea del "carácter arquitectónico" ${ }^{\prime 3}$ exhibiría los rasgos que lo harían distinguible y digno para ejemplificar los valores sostenidos por el Estado. Pero por otro, la escuela concretaba la difusión de los valores nacionales, extendía la argentinidad hasta aquellas regiones donde la presencia del Estado se hacía necesaria, tanto por la lejanía con los centros difusores más representativos, como por el riesgo real de incursiones extranjeras, no solo realizadas por confrontaciones violentas o invasivas únicamente, sino también, a partir de la lenta asimilación de costumbres propias de los pueblos que fueron poblando los territorios provincianos y que provocaron la existencia una matriz multiétnica que era necesario homogeneizar. De ese modo quedaba explicitada la voluntad de incorporar a las provincias a las coordenadas nacionales. Al mismo tiempo, mediante la temprana ley de educación primaria obligatoria, gratuita y laica de 1884 , el Estado reforzaba su visión estratégica del proceso de modernización, a partir de la construcción de la identidad nacional, acompañando el proceso de construcción material que corporizaba el nuevo EstadoNación ${ }^{84}$. Así el escenario planteado; la voluntad modernizadora y el deseo de irrumpir en las nuevas provincias, al resguardo de las más actuales ideas en el campo de la planificación y las ciencias sociales, colisionan con la realidad presente en los territorios sumados al conjunto provincial.

Es en esa coyuntura que los arquitectos Soto y Rivarola se adjudican los primeros premios de los concursos convocados para la provincia de Misiones. Produciendo una ajustada interpretación de las necesidades que el momento plantea, entendiendo de manera adecuada cómo actuar en cada caso, inmersos dentro del proceso de modernización que desde la óptica de Marshall Berman, viene desarrollándose en el país, desde casi cincuenta años.

83 -Para una mayor profundización del tema ver SHMIDT, Claudia (2012)."El carácter de las arquitecturas nacionales modernas: Excursus". En Palacios sin reyes; Arquitectura pública para la capital permanente, Buenos Aires 1880-1890, Rosario. Ediciones Prohistoria.p.143.

84 -SHMIDT, Claudia (2012). “Dignificados e iguales” En: Palacios sin reyes...cit.p.193 

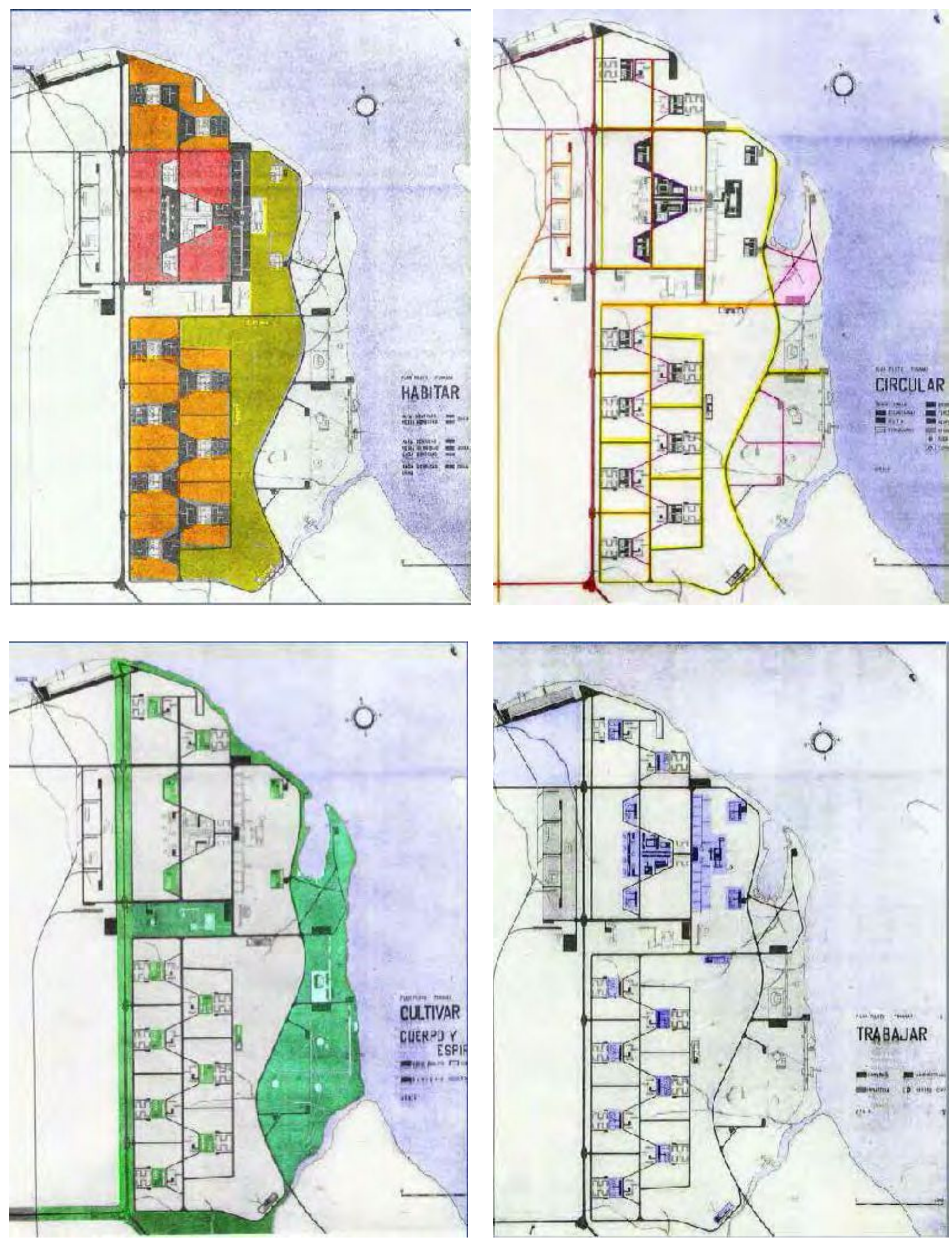

Imágenes 20; 21; 22 y 23 Distintos planos del Plan Urbis para Posadas, en los que, siguiendo los criterios volcados en la Carta de Atenas (1933) se analizan las distintas divisiones programáticas del "habitar" y se proponen funciones "vitales". 

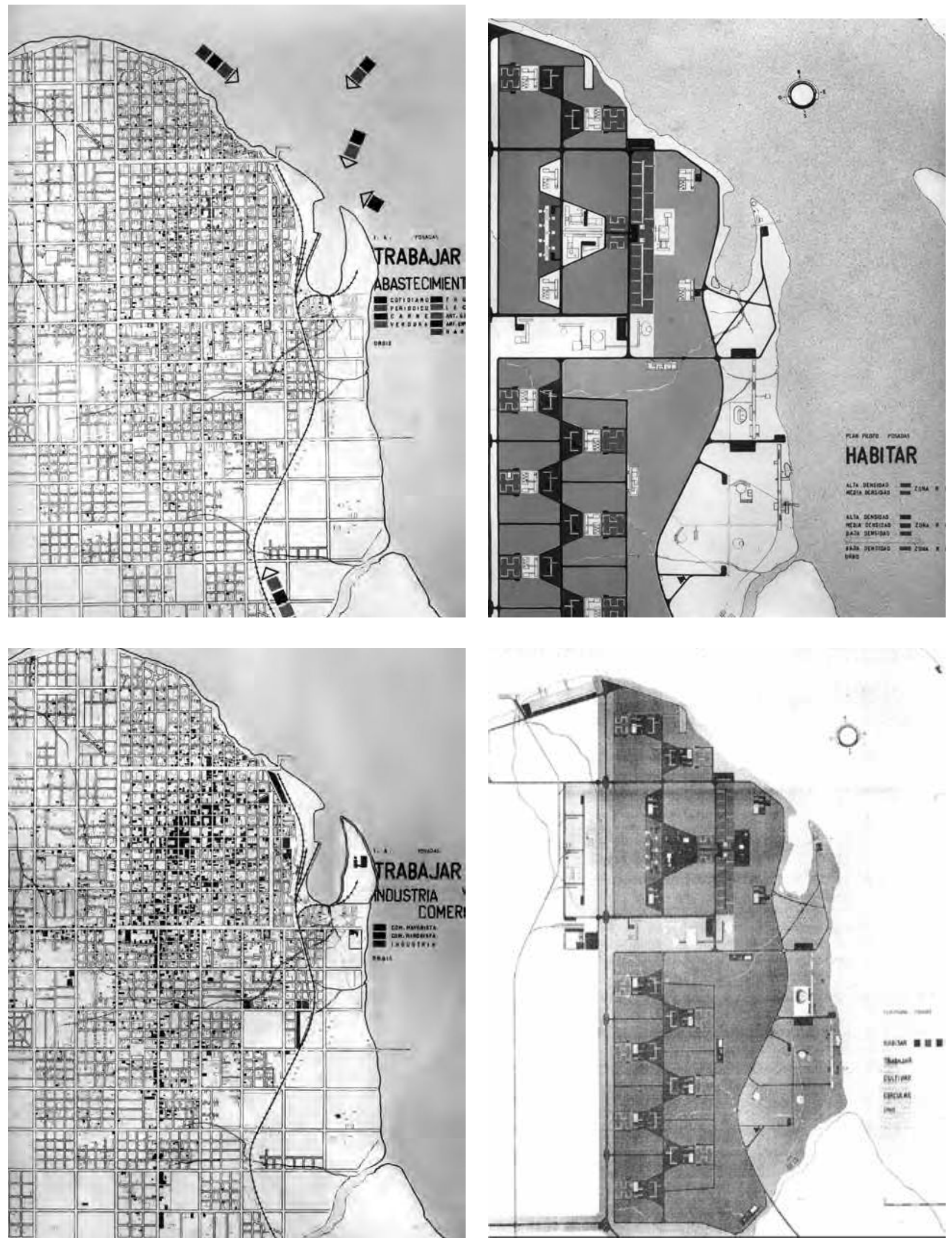

Imágenes 24; 25; 26 y 27 Distintos planos del Plan Urbis para Posadas, en los que, siguiendo los criterios volcados en la Carta de Atenas (1933) se analizan las distintas divisiones programáticas del "habitar" y se proponen funciones "vitales", más el análisis de las circulaciones necesarias entre ellas. 

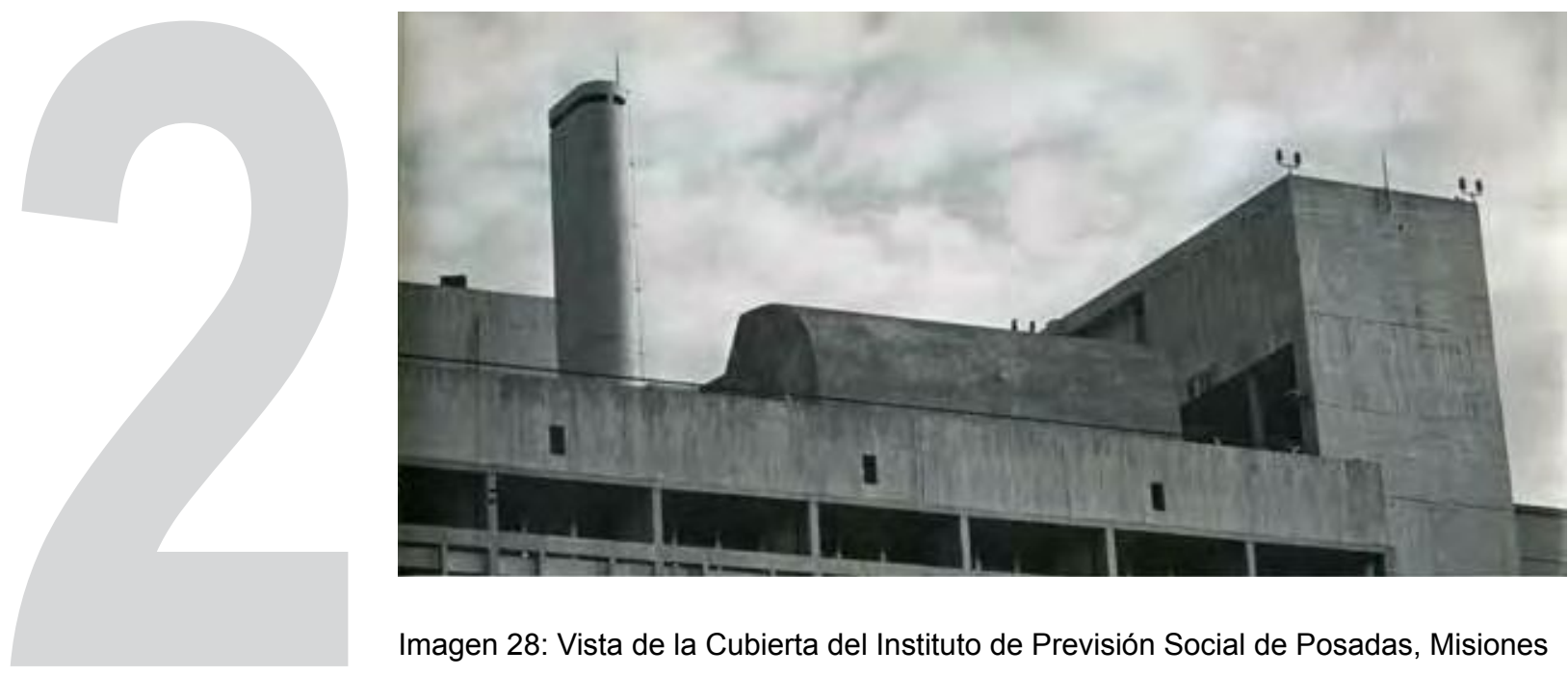

Imagen 28: Vista de la Cubierta del Instituto de Previsión Social de Posadas, Misiones 


\section{"Nothing succeeds as success"}

Francisco Bullrich (1963), en su libro Arquitectura Argentina Contemporánea, utilizó esta cita de Aldous Huxley ${ }^{85}$ para brindar una panorámica del estado de frustración que existía en la generación de arquitectos modernos que habían tenido activa participación en la década de 1940. Una gran cantidad de proyectos se habían convertido en fallidas experiencias; al Auditórium Municipal, concurso ganado por el equipo conformado por Eduardo Catalano; Raúl Grego, González Gandolfi, y gran cantidad de colaboradores, se sumaban los tres centros sanitarios proyectados por Amancio Williams para la provincia de Corrientes, o la ciudad Universitaria de Tucumán, proyectada por Eduardo Sacriste, Rafael Oneto, Horacio Caminos, Eduardo Catalano, Enrico Tedeschi, Jorge Vivanco, Hilario Zalba, entre otros. Esta sensación se acentuaba aún más, al corroborar que los edificios construidos por el Estado, durante este período, exhibían todos los rasgos de la arquitectura clásica que aquellos irrealizados proyectos querían combatir. La Facultad de Derecho, la repetición del mismo proyecto para el edificio destinado a la Ayuda Social, el Aeropuerto Internacional de Ezeiza, son solo algunos ejemplos de los edificios que conformaban la matriz de obra pública ejecutada durante 1940.

Un escenario completamente distinto es el que se planteó durante la década de 1950. Se inauguró, prácticamente, con el concurso para el Edificio de la Cámara Argentina de la Construcción, donde Testa, Dabinovic; Gaido y Rossi ganaron en 1951 el primer premio, obtuvieron luego en 1955 el primer premio para la Sede de Gobierno y dependencias administrativas de la Provincia de La Pampa.; en 1953 Santiago Sánchez Elía, Federico Peralta Ramos y Alfredo Agostini ganaban el primer premio para la construcción de la Municipalidad de Córdoba. Fue durante este período, que una nueva generación de jóvenes arquitectos se incorporó a la actividad profesional, insertándose en una coyuntura que si bien les aportó el marco adecuado para concretar su crecimiento, al mismo tiempo, les requirió el desarrollo de una mirada crítica para poder interpretar las demandas que el momento requería. Soto y Rivarola consiguieron los primeros premios de las obras más significativas, que durante la segunda mitad de la década de 1950 y principios de 1960 se concursaron y construyeron en Misiones. Iniciando la serie de premios con la construcción de Cuatro Escuelas de madera, en 1956, Seis Hosterías de Turismo, la Escuela Normal Número 1 en Leandro N. Alem en 1957 y finalmente el Instituto de Previsión Social en la Ciudad de Posadas en 1963. Resulta un dato interesante, detenerse en la conformación del jurado de éste último, en donde la presencia de Raúl Grego, autor de aquel fallido proyecto para el Auditórium, afirmó la positiva renovación generacional y propuso una suerte de momentáneo final feliz, a la serie de trabas a las que la arquitectura moderna tuvo que enfrentarse. El Banco de Londres de Clorindo Testa, junto al Estudio Sepra en 1960, y la Biblioteca Nacional también de Testa, pero junto a Bullrich y Alicia Cazzaniga en 1962, fueron la confirmación de este momento dorado de la producción arquitectónica argentina. 
Debe tenerse en cuenta, para iniciar el análisis de la producción de Soto y Rivarola, que varias de las obras de relevancia ejecutadas por la oficina en la provincia, fueron escuelas.

Si recorremos a vuelo de pájaro el territorio argentino, es posible reconocer la fenomenal impronta de la arquitectura escolar. Es a través de las escuelas palacio, los edificios monumentales del centenario, las grandes composiciones en torno a patios y jardines, las magníficas escuelas normales, los complejos de educación agrotécnica, los hogares escuela, las escuelas ciudad, que se puede apreciar clara y directamente las marcas históricas de la modernización y el progreso en Argentina. ${ }^{86}$

Este mito real, el de un país como una suerte de "aula universal" estuvo sustentado no solo en grandes ideas, debates y legislaciones, o en el accionar de pedagogos, educadores y docentes, sino también en la creación de una formidable infraestructura edilicia distribuida por todo el territorio nacional. Casi todas las escuelas que se construyeron en el país, tienen prestancia, se erigieron en hitos urbanos o rurales y corporizaron la institucionalización de la enseñanza. Los casos de las escuelas proyectadas por Soto y Rivarola, atravesaron de manera coincidente los tópicos de las concreciones, que en materia de arquitectura escolar desarrolló el Estado Nacional en diversos planes, llevados a cabo entre 1950 y 1960.

A continuación, se analizarán los proyectos para las cuatro escuelas de madera, en las que racionalidad constructiva, flexibilidad de uso, indeterminación y posibilidad de crecimiento ilimitado, fueron las premisas que guiaron la ejecución del proyecto y la materialización de la obra. 


\section{Cuatro escuelas de madera}
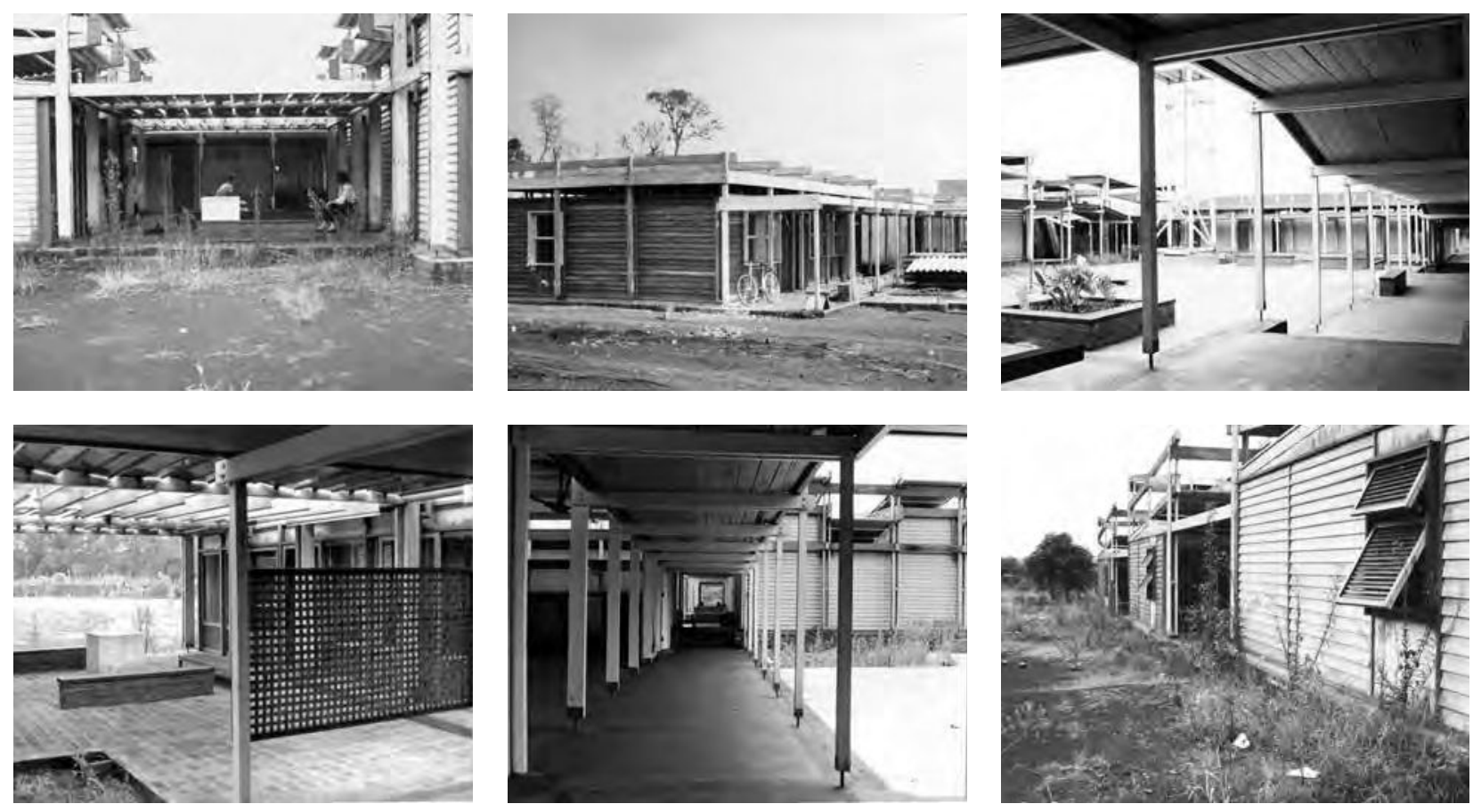

Imágenes: 29; 30; 31; 32; 33 y 34: Fotos de una de las cuatro escuelas construidas según el Concurso premiado.

El caso de las escuelas de madera se inserta dentro de la problemática que anticipó, de alguna manera, los objetivos que los módulos ER65 y ER66 ${ }^{87}$, intentaron llevar a la práctica apenas unos años después. La modulación y estandarización, se convirtió en el leitmotiv que dominó, buena parte de los proyectos ejecutados durante la segunda posguerra. La racionalización invadió la arquitectura escolar en todos los emplazamientos y persiguió la búsqueda de un resultado que permitiese optimizar plazos y costos, alentando la experimentación y el uso de nuevas tecnologías. De la mano de los manuales de la Post War Building Studies, Heating and Ventilation of Schools, Published for the Ministry of Works by the Majesty 's stationery office sixpence net, Soto y Rivarola buscaron alcanzar estos preceptos. (ver anexo, pág. 108 a 112; imágenes 194 a 197)

El 6 de Septiembre de 1956, se efectivizó el llamado a concurso para la realización de un primer grupo de obras, que surgió, del Decreto Provincial N548 del Plan de Trabajos Públicos del año 1956 y del Plan Estratégico para Misiones del grupo Urbis. ${ }^{88}$ Esta experiencia quedó comprendida en un período en donde es posible identificar una serie de intentos por relanzar a la Argentina, de cara a la segunda mitad del siglo XX, en la senda de una nueva modernización y un "nuevo progreso", resignificando el rol del Estado que asumió el papel de orientar estratégicamente la inversión y potenciar a la educación para calificar a la población ${ }^{89}$ y materializar en el territorio construcciones de alto poder simbólico. En este marco, el Gobierno de Misiones, dio intervención a la Asociación de Profesionales de la Ingeniería y Arquitectura de aquella provincia. Solicitó también, el patrocinio de la Sociedad Central de Arquitectos, para concretar el llamado a concurso Nacional y elaborar las Bases y Condiciones que regirían la compulsa para construir cuatro escuelas, seis unidades sanitarias y cinco comisarías, que se distribuirían en distintas localidades de Misiones.

87 -ER 6 y ER 66 fueron prototipos para escuelas rurales realizados bajo la normativa para América Latina impulsada desde la UNESCO a través de la CONESCAL. GALVAN DUQUE, Héctor (1963) Cartilla de autoconstrucción para escuelas rurales. México : Conescal, 1963.

88 -Ver anexo, GOBIERNO DE LA PROVINCIA DE MISIONES, MINISTERIO DE ECONOMÍA Y OBRAS PÚBLICAS (1956) Concurso de Anteproyectos de edificios incluidos en el Plan de Trabajos Públicos. (imág. 17-18-19). p.15. 
Las bases reglamentaban diversos aspectos del concurso, determinaban la cantidad y el tipo de piezas gráficas y documentación que cada equipo profesional debía producir, como así también obligaciones de los participantes y atribuciones del jurado. Al mismo tiempo establecía para cada uno de los edificios requeridos un emplazamiento tentativo y posible, aunque no definitivo.

Se adjuntaba, además del programa de necesidades y superficies, planos de cada localidad, como también de la provincia y "antecedentes locales actualizados" ${ }^{\text {" }}$, condiciones climáticas y régimen de precipitaciones anuales y vientos dominantes, todos estos factores deberían ser atendidos, por sus características extremas. En este caso, la región estaba dominada por un clima cálido uniforme, con escasa amplitud térmica, oscilando entre veranos muy tórridos e inviernos templados. Con abundantes lluvias durante los meses de primavera y vientos predominantes de los sectores Noreste y Sudeste. Siendo también frecuentes los del sector Norte, que aportan excesivo calor.

Además sugería una lista de materiales posibles de conseguir en cada localización, en donde se daba preferencia a las maderas autóctonas, como Guatambú blanco, Incienso, Rabo amarillo, Cedro misionero, Grapia, Anchico colorado, Petiribí, Mora amarilla, entre otras. Se promovía la utilización de tacurú y de tacuaras, al igual que la piedra mora y ladrillos.

Hacia el final del año 1956, Soto y Rivarola, obtuvieron el primer premio para la realización de las cuatro escuelas, que serían construidas en las localidades de: Libertador General San Martín; Eldorado; Campo Grande y Aristóbulo del Valle. El jurado ${ }^{91}$ celebró la alta jerarquía arquitectónica y consideró que se realizaba, mediante esta propuesta, un importante aporte creativo a la resolución de edificios escolares..$^{92}$ Exaltó, al mismo tiempo que la exuberancia espacial y formal, se lograba con ponderable simplicidad de medios. Un planteo sumamente claro, lograba una estrecha vinculación entre la vida escolar del niño y el paisaje. Consideraba un acierto el desmembramiento y la identificación de cada elemento del programa, que se ubicaba en construcciones separadas, que así dispuestas formaban verdaderos locales exteriores, vinculados a los locales cerrados. Aprobaban la utilización de los materiales del lugar, el planteo constructivo, la simplicidad de la técnica necesaria para su materialización, la generosidad de las dimensiones dadas a los accesos, al igual que el tamaño y las proporciones de la unidad "aula", al mismo tiempo que remarcaban la fluidez de comunicación visual y uso entre el patio cubierto, el aula y el espacio circundante; finalmente consideraban un enorme acierto la flexibilidad con la que cada escuela podía adaptarse a las condiciones específicas de cada emplazamiento ${ }^{93}$, lo que remarcaba la condición inespecífica del lugar asignado, como así también el carácter prototípico de cada resolución.

Los autores por su parte, enunciaban en la memoria descriptiva aquellos temas que habían tenido en cuenta para la elaboración del proyecto. Se iniciaba con el clima; de su análisis surgía la necesidad no solo de contemplar la orientación y el recorrido del sol, sino también disponer elementos de protección que colaboraran para brindar el confort necesario para el desarrollo de las actividades previstas ${ }^{94}$.

90 Ver Anexo; GOBIERNO DE LA PROVINCIA DE MISIONES, MINISTERIO DE ECONOMÍA Y OBRAS PÚBLICAS (1956) Concurso de Anteproyectos...cit.(imag.17-18-19) p.15.

91 Estaba integrado por un representante de la Entidad Promotora, Gobierno de la Provincia de Misiones; dos miembros del jurado de concursos de la Sociedad Central de Arquitectos, designados por sorteo, un representante propuesto por la Asociación de Profesionales de la Ingeniería y de la Arquitectura de la Provincia de Misiones y finalmente uno sugerido por los participantes p.10.

92 Ver Anexo; Fallo del jurado: Planteo arquitectónico. (imag.20-21) p.16

93 Ver Anexo; Fallo del jurado: Funcionalidad. (imag.20).p.16.

94 Ver Anexo; Memoria de los autores: Partido (imag. 21/24) p.17 a 20. 
Soto y Rivarola hacían una expresa consideración del carácter transitorio del entorno donde se implantarían las escuelas, suponiendo la transformación constante del espacio urbano, establecían la imposibilidad de crear una relación rígida entre el edificio y su "nuevo escenario"

Los estudios en cuanto a la materialidad, formaban parte de los ítems enunciados por los autores en la memoria y ya habían sido evaluados desde el momento inicial de lectura de las bases ${ }^{95}$. Efectivamente reconocidos como "datos del problema", habían sido subrayados aquellos que despertaban en los autores interés, tanto por sus posibilidades constructivas como por sus características expresivas ${ }^{96}$, al mismo tiempo que su elección estaba regulada por la concreta posibilidad de ser utilizados e incluidos en la obra mediante el empleo de técnicas simples de montaje y construcción.

Establecían un "plano tipo" como una idea unificadora de criterios conceptuales, funcionales y constructivos, pero evitaban que la solución adoptada constituyera un armado rígido que no permitiera la adaptación a los problemas que plantearía cada localización.Finalmente enunciaban "el partido" adoptado como un punto de equilibrio entre los partidos abiertos y los partidos cerrados, entre los dispersos y los concentrados ${ }^{97}$.

El edificio resultante conforma un interesante ejemplo de arquitectura de pabellones, volúmenes dispersos y funciones diferenciadas, vinculados a partir de corredores y circulaciones que materializadas mediante galerías ordenan el conjunto y hacen visibles los ejes de la "composición".

El planteo de la escuela adquiría un carácter prototípico. Es posible realizar múltiples lecturas de la planta. Una es considerar al conjunto como un gran rectángulo cuyos lados cortos ofician de tapas con perforaciones en el centro, que se alinean con el eje longitudinal. Un volumen que contiene la cocina, está ubicado en el centro mismo del eje estableciendo dos accesos secundarios a cada lado, dos galerías, semicubiertas recorren tangencialmente un patio cubierto, que se ubica a continuación de aquel primer pabellón y lo limitan. Es allí donde entra en juego un segundo eje perpendicular al anterior, que conforma el acceso principal y divide en partes asimétricas al conjunto. El rectángulo conformado por la planta total de la escuela, queda seccionado en tres partes en el sentido transversal: una primera, la más estrecha, compuesta por una serie de funciones en cuyo centro se ubica la mencionada cocina y los accesos secundarios a cada uno de sus lados. Una segunda sección que opera por ausencia: un patio semi-cubierto limitado por dos galerías que recorren la totalidad de la planta. Finalmente la tercera, un gran rectángulo en el que se colocan, sobre sus lados más largos una secuencia de aulas alternadas, intercalando unos patios pequeños entre ellas, abrazando un centro que vuelve a ser vaciado: el patio principal de la escuela.

Éste queda rodeado y contenido por la composición rítmicamente organizada establecida por la sucesión del lleno del espacio del aula y su contraforma, el vacío del patio secundario que las separa. Esta lectura, si no se tuviera en cuenta la disposición volumétrica, podría brindar una descripción engañosa, sería posible interpretarlo como un prisma horadado, un volumen que ha surgido del producto de la sustracción de algunas de sus partes, cuando en realidad es el resultado de la disposición fragmentaria de partes programáticas resueltas mediante piezas individuales, a partir de la organización de la planta.

95 Ver Anexo: Memoria de los autores concurso para las escuelas. (imag. 24).p.10.

96 Ver Anexo; Escaneado de Bases para el concurso de Anteproyectos de Edificios incluidos en el Plan de Trabajos Públicos Año 1956. (imag. 24-26-27).p.10. 


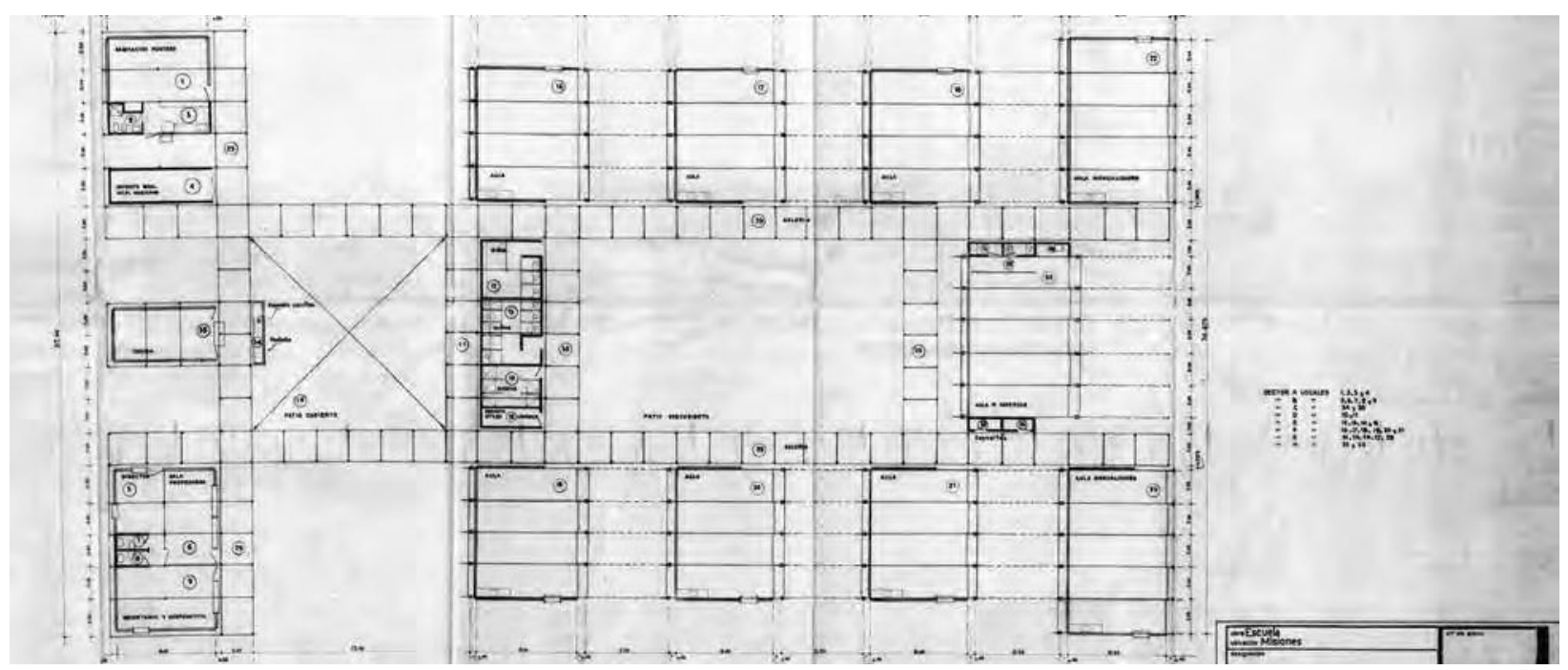

Imagen 35: Planta que integraba el legajo técnico confeccionado para realizar la licitación de la obra

El volumen resultante de la Escuela no surge de la operación con una totalidad ni de la manipulación de una forma única; sino de la adición de partes autónomas reguladas según criterios de composición y ejes de simetría.El resultado formal de las escuelas proviene de la interpretación de cada función tratada individualmente y expresada de manera particularizada y singular, atendiendo las correctas proporciones de cada una de ellas. El conjunto se organiza con una misma regla compositiva, tanto en el sentido transversal como en el longitudinal. Aunque disponiendo una mayor complejidad sobre éste último. Franjas de volúmenes sólidos, se alternan con otras semicubiertas, para luego dejar un espacio desocupado, realizando una transición entre espacios llenos, semi cubiertos y vacíos que se organizan rítmicamente y se repiten de manera simétrica. En el sentido longitudinal esta alternancia se realiza ubicando cinco franjas llenas, separadas mediante cuatro vacíos intercalados.

El efecto conseguido permite otorgarle al edificio, una diversidad de espacios que atienden con escala adecuada a las funciones que contienen, exhibiendo una resolución particularizada e individual, a partir de la conformación de cada cubierta, que es tratada como una pieza única y que surge de la repetición de un solo elemento: efectivamente, a excepción del techo del patio cubierto, que demanda mayores luces sin apoyos, la totalidad de las aulas y demás volúmenes, se resuelven mediante una doble cabreada de madera, en cuyo borde superior se dispone una serie de parasoles del mismo material, que mitigan el impacto del sol sobre la cubierta, que en el borde inferior, queda resguardada por aquellos. Unas vigas perimetrales soportadas por finas columnas dobles completan el planteo constructivo-estructural.

Así mediante esta disposición, se logró un esquema que operó con un enorme grado de flexibilidad, brindando al edificio, la capacidad de adaptación a distintas condiciones de lotes, medidas y orientaciones, oficiando los espacios vacíos entre las distintas funciones, como fuelles capaces de absorber las irregularidades que cada localización pudiera proponer.

Todo esto se consiguió sin hacer concesión alguna a la calidad arquitectónica del edificio, el resultado obtenido es de enorme riqueza espacial y de una eficaz fluidez entre las partes. El proyecto lograba regular criterios de serialidad y al mismo tiempo de singularidad. El planteo y disposición de cada sector, entendido como múltiples pabellones que se distribuyen de acuerdo a una estricta organización que es regulada mediante ejes mayores, menores y simetrías, simultáneamente, puede verificarse la marcada intensión de identificar cada una de las partes, de acuerdo con un criterio de jerarquías. 


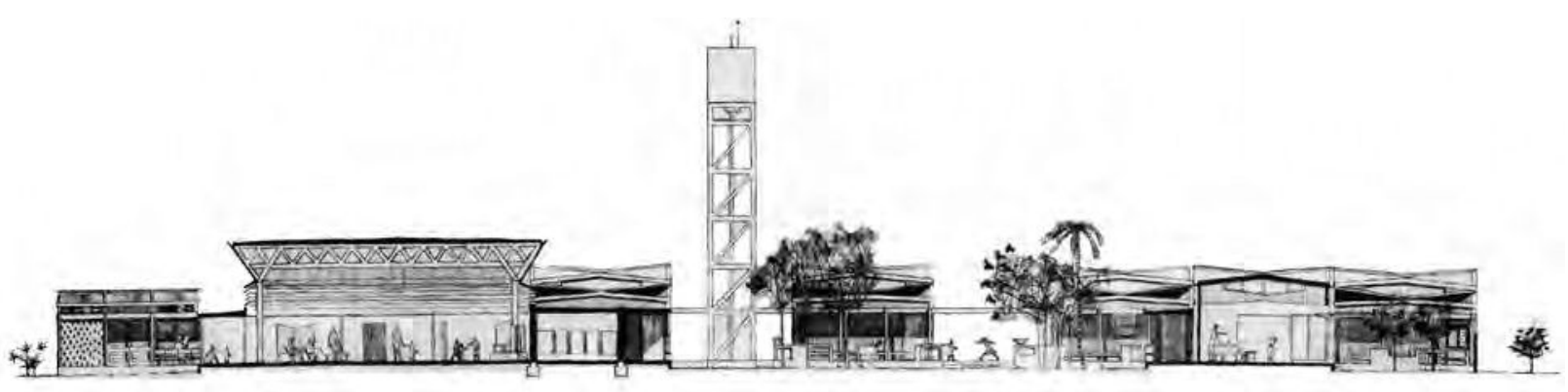

Imagen 36: Corte longitudinal que formaba parte del panel original presentado al concurso

Es decir, la forma, estrechamente vinculada a la función, se sirve de la resolución material que refuerza su reconocimiento y ubicación dentro de un conjunto clasificado y ordenado según la importancia asignada a cada parte programática.

Esta manera de concebir el proyecto tendrá a partir de la década de 1960, un desarrollo que se generalizará en el ejercicio de la práctica arquitectónica. No es el objetivo plantear el presente caso como un antecedente, aunque sí trazar e identificar las relaciones y búsquedas intelectuales que tensaban el momento. De este modo, es posible encontrar en el planteo de las escuelas una similar matriz teórica, a la que unos años más tarde regulará la denominada "arquitectura de sistemas", definida por Aliata98,

\section{(... ) como una metodología de proyecto que tiende a la constitución de un sistema de partes, funcionales y constructivas, apto para la materialización de diversos tipos de edificios. Esta arquitectura se encuentra unida a otro tipo de saberes teóricos, como metodologías de diseño, y las nociones de flexibilidad y crecimiento, exhibiendo una coherencia de sus postulados internos en los que la idea de sistema va unida a la racionalidad constructiva en pos de conseguir la optimización de los tiempos de obra y los bajos costos de ejecución.}

A diferencia de la mencionada corriente arquitectónica, vinculada a los campos científicos y a la teoría general de sistemas ${ }^{99}$, el caso de las escuelas se produce de manera anterior. Los identificados conceptos de flexibilidad, crecimiento e indeterminación, fueron requeridos por el encargo que no especificaba localizaciones precisas. Al mismo tiempo, la búsqueda por "caracterizar" las estructuras tipológicas de acuerdo con su función, y vincularlas mediante los sistemas circulatorios, cosiendo cada uno de los subconjuntos, se presentó como una premisa del planteo arquitectónico realizado por Soto y Rivarola. Dando como resultado un edificio de características sistémicas, originado a partir de una similar matriz de necesidades pero surgido de un diferente punto de partida. Este método y manera de concebir el proyecto encontrará en el caso de las hosterías, la ocasión para alcanzar un mayor grado de refinamiento y precisión.

98 Voz: "Arquitectura de Sistemas" En: LIERNUR, Jorge Francisco; ALIATA, Fernando (Comp.) (2004). Diccionario de Arquitectura en la Argentina...cit.pp.57-60.

99 La Teoría General de Sistemas surgió de a la necesidad de abordar científicamente la comprensión de los sistemas concretos que forman la realidad, generalmente complejos y únicos, resultantes de una historia particular, en lugar de sistemas abstractos como los que estudia la física. La TGS fue planteada originalmente en 1950 por el biólogo austríaco Ludwig von Bertalanffy, más luego Humberto Maturana en la década de 1970 desarrolló el concepto. Su vinculación al campo teórico de la arquitectura se da entre la década de 1960 y 1970 

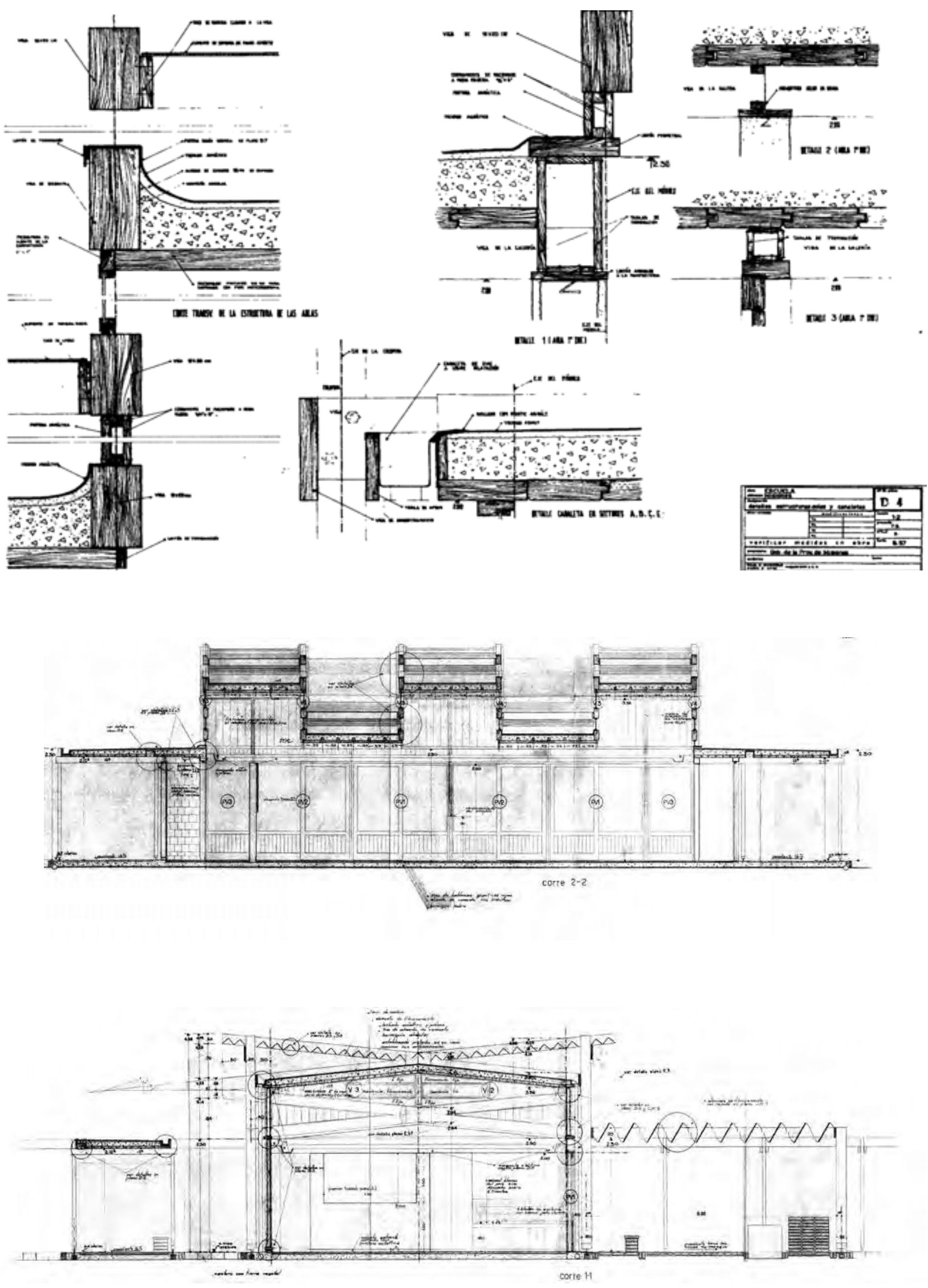

Imagen 37; 38 y 39: Detalles de "nudos" y distintos encuentros y sus soluciones constructivas; Ubicación de esos puntos en los distintos cortes. 

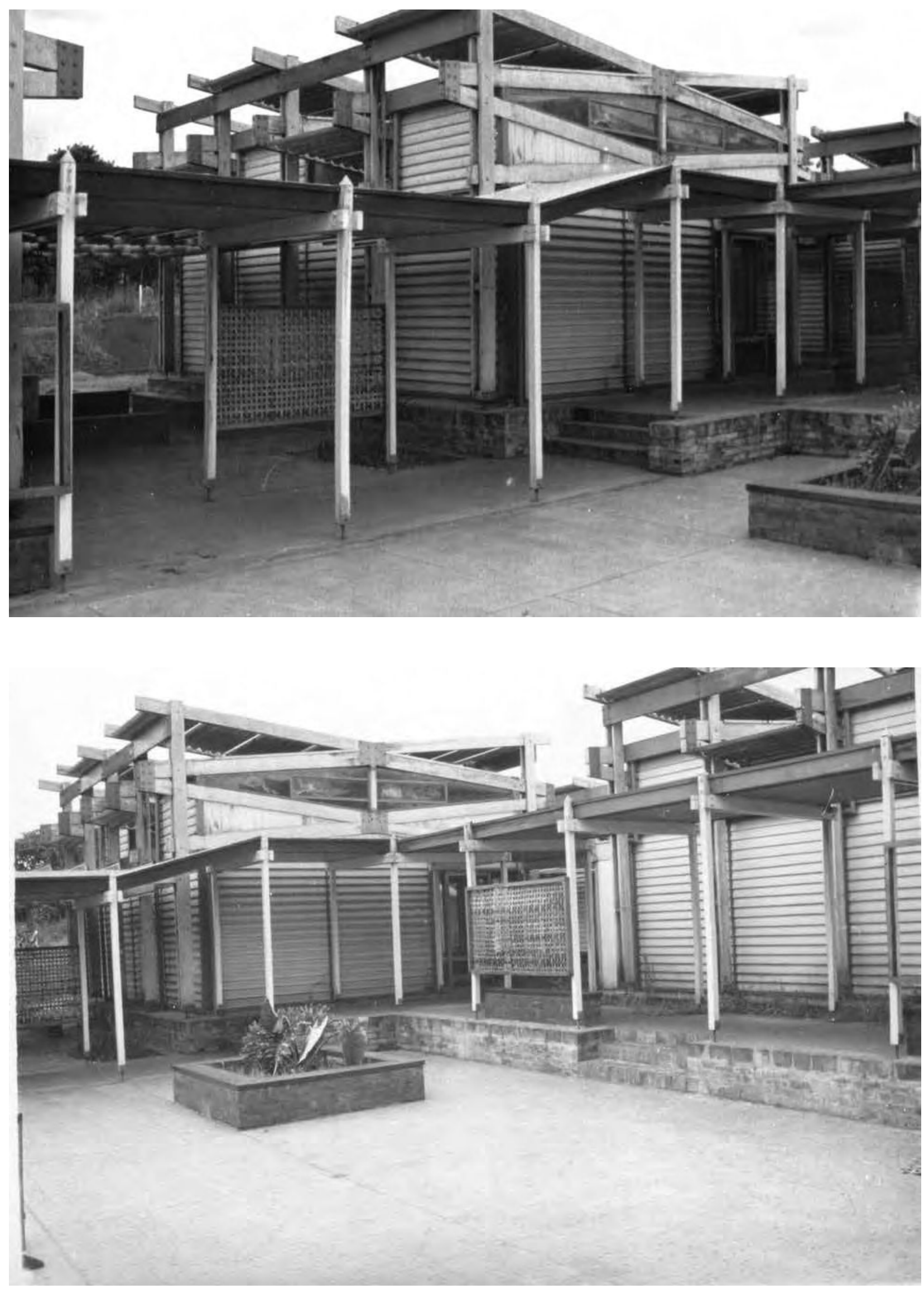

Imágenes 40 y 41: Fotos de los patios interiores y galerías de circulación. 


\section{Seis hosterías de madera}
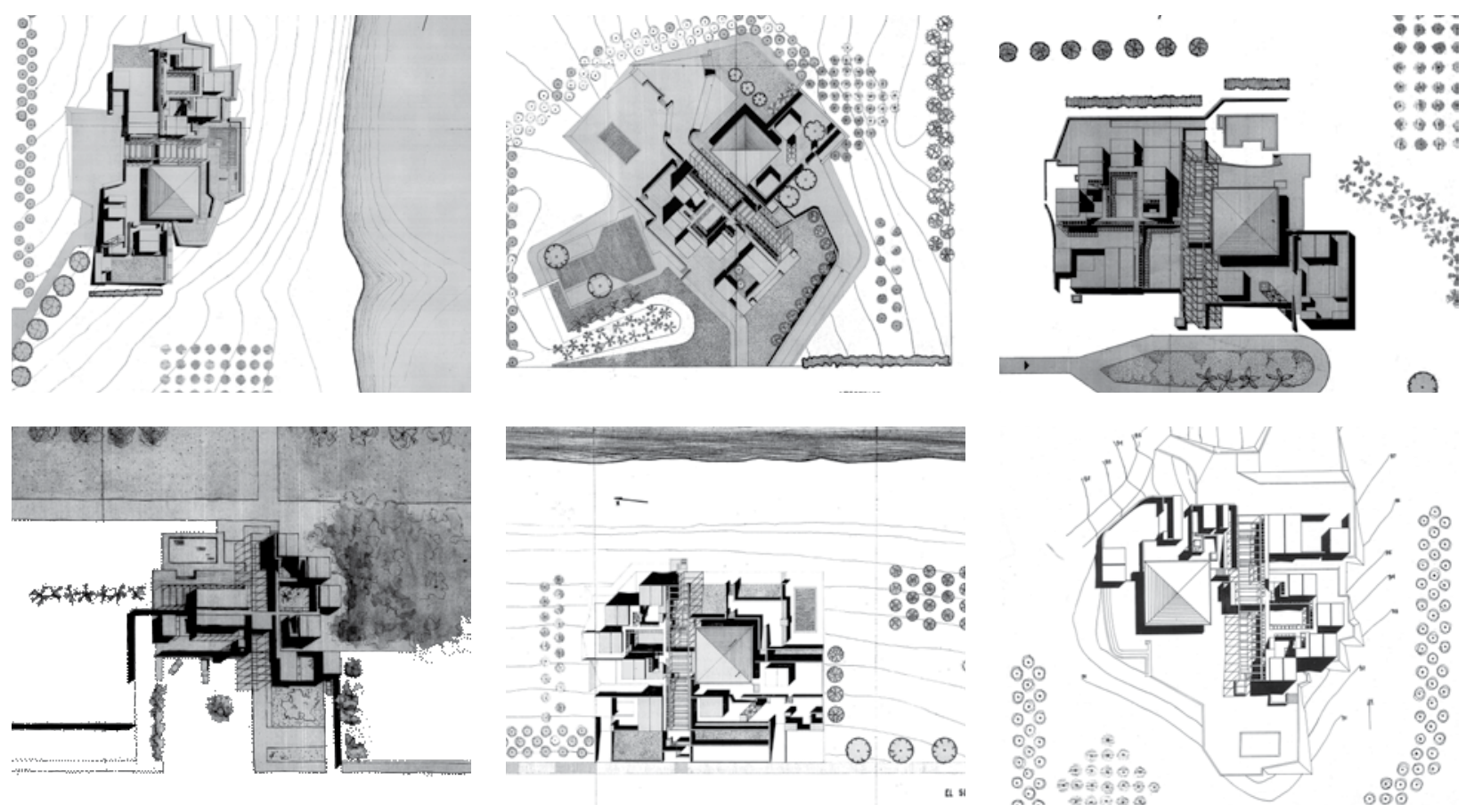

Imágenes 42; 43; 44; 45 ; 46 y 47: Alba Posse; Apostoles; Bernardo de Irigoyen; Eldorado; El Soberbio; Montecarlo

El 20 de diciembre de 1956, apenas diez días después de la fecha de entrega de los proyectos correspondientes al llamado a concurso para la construcción del primer grupo de obras contenidas en el Plan de Trabajos Públicos del año 1956, por medio del decreto $\mathrm{N}^{\circ} 1110$, se realizaba un nuevo llamado a concurso para realizar un segundo grupo de obras, que estarían conformadas por tres hoteles, tres hosterías de tránsito y cuatro hosterías de turismo, para ser ubicadas, al igual que en el llamado anterior, en distintas localidades del territorio provincial de Misiones, contando de igual manera, con la Asociación de profesionales de la Ingeniería y Arquitectura, y con la Sociedad Central de Arquitectos, como auspiciantes.

Nuevamente el equipo conformado por Soto y Rivarola, obtuvo el primer premio para la construcción de las hosterías de turismo, que originalmente serían tres y luego se ampliarían a seis, pensadas para las localidades de Bernardo de Irigoyen, El Soberbio, Apóstoles, San Javier, Eldorado y Montecarlo. Finalmente solo se construirán las ubicadas en estas tres últimas localidades.

Los autores desarrollaron una base conceptual y operativa, que retomaba la metodología utilizada para el caso de los trabajos realizados para los concursos de las escuelas. Una memoria técnico constructiva, desplegaba los temas tenidos en cuenta, como las estrategias empleadas para la elaboración de los proyectos, que al igual que en el caso anterior, revestían un carácter prototípico, ya que debían actualizarse y amoldarse a una localización que en el momento de la convocatoria del concurso no estaba aún definida.

Iniciaban el planteo describiendo las condiciones del clima que las hosterías deberían enfrentar, haciéndose evidente la experiencia adquirida a partir del desarrollo del primer concurso, ya que se incluyeron aspectos como las ventilaciones cruzadas, la ubicación alternada de espacios llenos y vacíos, que no habían sido mencionados en la memoria anterior. 
La relación con el paisaje, era abordada teniendo en cuenta la diversidad que cada localización proveería al proyecto, previendo la posibilidad de adaptación de cada una, aun anticipando la posibilidad real de que se podrían alterar las formas planteadas pero no el criterio. ${ }^{100}$

El desarrollo del plano tipo, seguía exactos lineamientos a los utilizados en ocasión del planteo del proyecto para las escuelas, pero avanzaba en la posibilidad de que las plantas pudieran espejarse, según el margen del río en que se colocaran, aunque atendiendo las condiciones particulares impuestas por la orientación, dejando siempre el sector de las habitaciones a resguardo de la mayor exposición al sol. Un aspecto en el que se pone de manifiesto la adquisición de saberes específicos en cuanto al clima de la región está dado por la técnica constructiva propuesta, que si bien mantenía el espíritu de resolverse con economía de medios y construcción tradicional, avanzaba en el empleo de la técnica utilizada. Se proponía para la resolución del techo, la utilización de una estructura de madera con una primera cubierta del mismo material, sobre ella se aplicaría una capa de hormigón alveolar y un manto hidrófugo. Por encima de ésta se colocaría otra cubierta formada por una estructura de viguetas y chapas de fibrocemento, cuya utilidad sería la de arrojar sombras sobre el primer techo e impedir que el agua, fruto de las intensas precipitaciones llegara hasta él, permitiendo su aprovechamiento a partir de la canalización para su reutilización posterior.

La propuesta de las hosterías para Bernardo de Irigoyen, Montecarlo, Apóstoles, Alba Posse y El soberbio marca a primera vista similitudes, en cuanto al planteo general y a la disposición de las "partes". Una amplia galería materializa la circulación principal, cubierta por una pérgola en doble altura, estructura el planteo general, se ubica como espacio de asociación más trascendente y conforma claramente dos zonas, que quedan divididas por ella. Hacia uno de los lados se ubica el cuerpo de las habitaciones resueltas en dos plantas, unidas en pares que manifiestan un subgrupo funcional en torno a un patio, se proyectan en forma de claustro, cerrando parcialmente el interior abierto, que es cubierto por una pérgola de menor altura que la circulación principal, articulando la relación entre las distintas habitaciones, reforzando la materialización del subconjunto. Un grupo de instalaciones secundarias completan el sector y se disponen a un lado de la circulación principal. Enfrentadas a ellas se ubican los sectores comunes, el restorán, la administración, claramente individualizada, a partir de la conformación volumétrica coincidente con su función particular. Un cuadrado de 22 metros de lado, es cubierto con un techo a cuatro aguas, cuyo planteo es consecuencia formal y constructiva, del comedor y patio cubierto, de las escuelas de madera, anteriormente analizadas. ${ }^{101}$
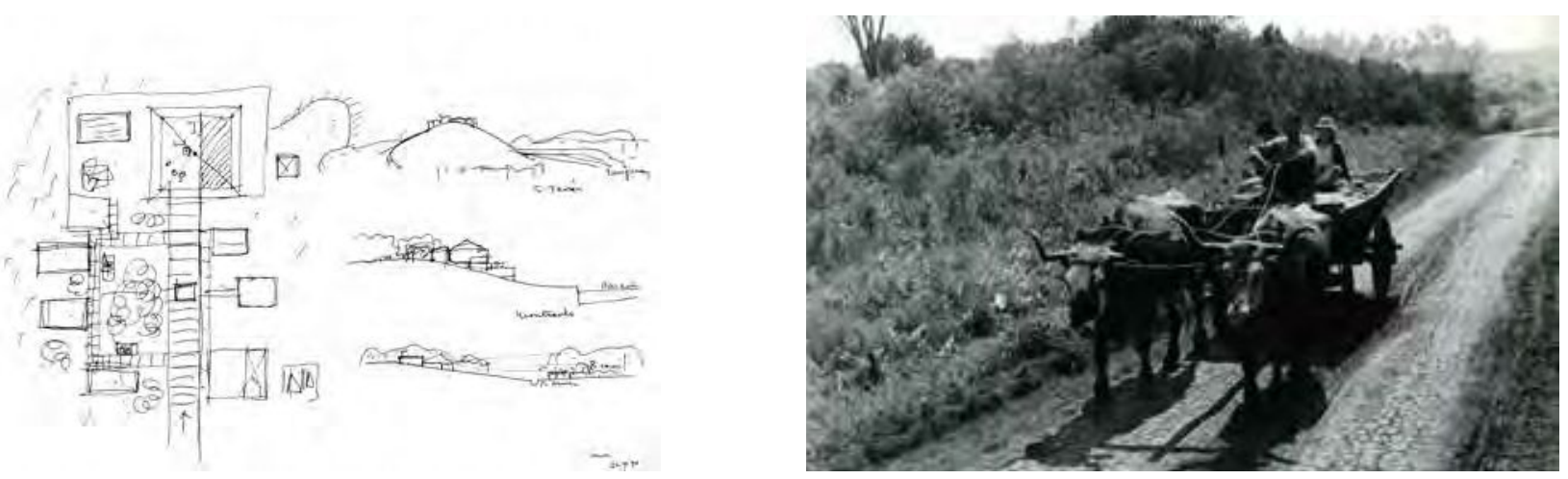

Imágenes 48 y 49: Dibujo conceptual, realizado por Rivarola, para explicar las ideas y los temas tenidos en cuenta al momento de diseñar las hosterías. Foto contemporánea de Misiones al momento de realizar las obras.

100 Ver anexo: Memoria del concurso para las Hosterías: Mario Soto y Raúl Rivarola.(imag.61-62-63).p.38/40

101 Raúl Rivarola: de los reportajes efectuados en el transcurso de esta investigación Buenos Aires entre junio 2014 y diciembre de 2015 . 
Distintas circulaciones que conforman un paseo, la piscina y las instalaciones deportivas completan el sector, que siguiendo el sistema de referencias propuesto, se ubican a la derecha de la circulación principal.

Constructivamente evitaban la utilización de revestimientos, los materiales quedan a la vista, piezas de madera, mampostería y piedra, conforman una paleta rica en articulaciones, colores y texturas, brindando enorme coherencia al conjunto. La rigurosidad del clima, caracterizado por un intenso calor y altos valores de humedad, fue atendida mediante la disposición de un sistema pasivo de acondicionamiento térmico, que con la interposición de piezas de madera y aberturas pequeñas en las caras más expuestas a las orientaciones menos favorables, buscaba regular la temperatura interior. El sistema se completaba con la disposición de ventilaciones cruzadas. Pese a las diferentes condiciones de emplazamiento, pendientes y realidades particulares de cada localización, todas las hosterías participan de un fuerte sentido de unidad. Una misma matriz geométrica ordena las partes y formulan una "tipología" de hostería, brindando un claro reconocimiento al conjunto, como a un sistema, que orientado al turismo, posibilita su sencilla identificación. La lección del Automóvil Club Argentino, había sido definitivamente incorporada. ${ }^{102}$

En noviembre de 1990 el número 149 de la revista de la Sociedad Central de Arquitectos ${ }^{103}$, publicó un ejemplar dedicado a las grandes obras de arquitectura realizadas en la Argentina en los últimos 30 años. En ella Jorge Iribarne realizó a Rivarola, un extenso reportaje, que tuvo como foco el concurso y la posterior construcción de las hosterías y que fue acompañado con una importante cantidad de material gráfico y documentación tanto del proyecto como de las obras terminadas. Esta publicación se sumó a otras que la precedieron, entre la que se destaca la realizada por la revista Summa durante el año 1963, que recopilaba gran parte, no solo de la documentación tanto de las obras como del concurso, sino de la operatoria toda, poniendo en real magnitud la complejidad de la empresa llevada a cabo, unos pocos años antes, en la provincia de Misiones.

En este caso, el encabezamiento del artículo dedicado al estudio Soto y Rivarola y a las hosterías específicamente, puestas en relación con un conjunto de obras realizadas durante el mismo período (la Iglesia de Venado Tuerto de J. Solsona, R. Bauzá, C. Libedinsky; el Cementerio de Mar del Plata, de H. Baliero, y C. Córdova y el Monumento a Battle y Ordoñez de C. Testa. Completaban la sección de arquitectura artículos firmados por J. Solsona y Reyner Banham, entre otros) decía:

"Pese a la diversidad de temas, zonas y técnicas constructivas, estas obras han sido realizadas en una misma etapa de la arquitectura argentina y obedecen a una idéntica orientación generacional. Liberadas de los primeros esquematismos de la arquitectura moderna, son un aporte creativo de trascendencia que se trasunta en algo "argentino", quizás en algo latinoamericano, si por ello se entiende una seria preocupación por lo formal como expresión o símbolo de contenidos propios (...). Son significativos en estas obras el tratamiento fluido del espacio, el manejo de la iluminación y la valorización de la naturaleza de los materiales". ${ }^{104}$

102 GORELIK, Adrián (2001/2002). "Antonio Vilar, Peregrinazione del moderno Antonio Vilar e la rete di stazioni di servicio in Argentina 1938-1946”. Casabella Nºp.695-696.

103 IRIBARNE, Jorge (Diciembre de 1990). "Las hosterías en Misiones de los arquitectos Soto y Rivarola, hoy". En: Revista Sociedad Central de Arquitectos, N¹49. pp.56-70.

104 (1963) “Tres Obras en la Argentina”. Summa, N². pp.27-38..

46 
Es un hecho de lamentar que el resto del artículo por demás extenso, se completara solo con la memoria técnico-descriptiva de los autores que formaba parte de la documentación entregada en ocasión del concurso, desprovista de rasgos críticos o de una posición, que apenas esbozada en el encabezamiento, dejara leer un juicio realizado por la editorial que permitiese tener un registro de los aspectos valorados, como así también el estado del debate arquitectónico de ese momento. No obstante la publicación en paralelo de diversas obras contemporáneas, permitió recortar contra ese fondo la producción de Soto y Rivarola.
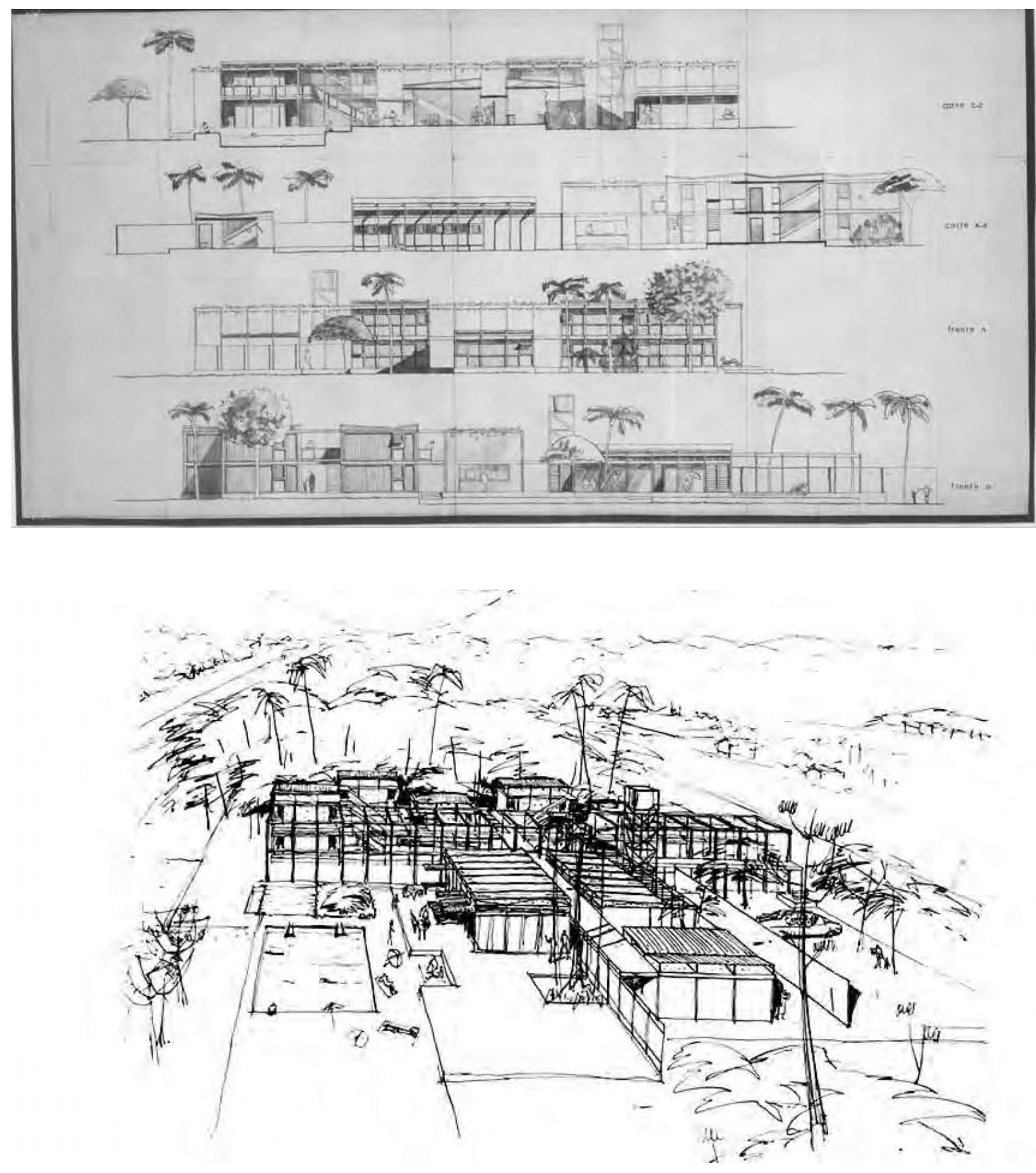

Imágenes 50 y 51: Panel de cortes y vistas original del concurso (integrante de la Exposición y del libro Latin America in Construction Architecture 1955-1980. The Museum of Modern Art, New York pp.99). Perspectiva ralizada en ocasión del concurso por Jorge de la Vega. 
Francisco Bullrich en el número 19 de la revista Summa sostenía que: "un arquitecto no deduce una imagen arquitectónica de un organigrama"105, con esta negación argumentaba en contra de la crítica al funcionalismo en su versión más simplificada, que comenzaba a cuestionar los resultados obtenidos por aquellas maneras sistémicas de pensar el proyecto arquitectónico. En tal sentido, las hosterías podrían ofrecer suficientes pruebas al argumento de Bulrich.

El proyecto aquí realizado por Soto y Rivarola, retoma una matriz desarrollada en el caso de las cuatro escuelas de madera, pero creciendo en complejidad profundiza las vinculaciones y relaciones entre las partes, promoviendo una serie de conexiones espaciales que enriquecen la experiencia del visitante. Comienza a vislumbrarse una mayor preminencia del corte en el planteo, que sin abandonar la ideación en planta, hasta aquí corroborada, permite enlazar los distintos sectores funcionales, dentro de un espacio enriquecido por la aparición de pérgolas en doble altura.

El diseño total de las hosterías, deja ver la existencia de partes programáticas, reunidas en torno a un sistema que se acopla mediante leyes propias, organizándose como subconjuntos. Distintas piezas articuladas, se conectan como engranajes de una maquinaria, que como hemos visto, propone y alterna situaciones acorde a las distintas escalas. De este modo, una solución plagada de articulaciones espaciales, resolvió las múltiples instancias que el programa planteó, manifestando una manera de operar ante los diversos requerimientos. Soto y Rivarola desarrollaron un "sistema" de intervención, más allá del constructivo, un modo de proyecto que les permitió abordar el problema de instalar una red de servicios turísticos en medio de la selva, bajo las condiciones que impuso un clima extremo y una infraestructura inexistente, pero sin resignar por ello, el objetivo de conferir excelentes condiciones arquitectónicas al resultado.

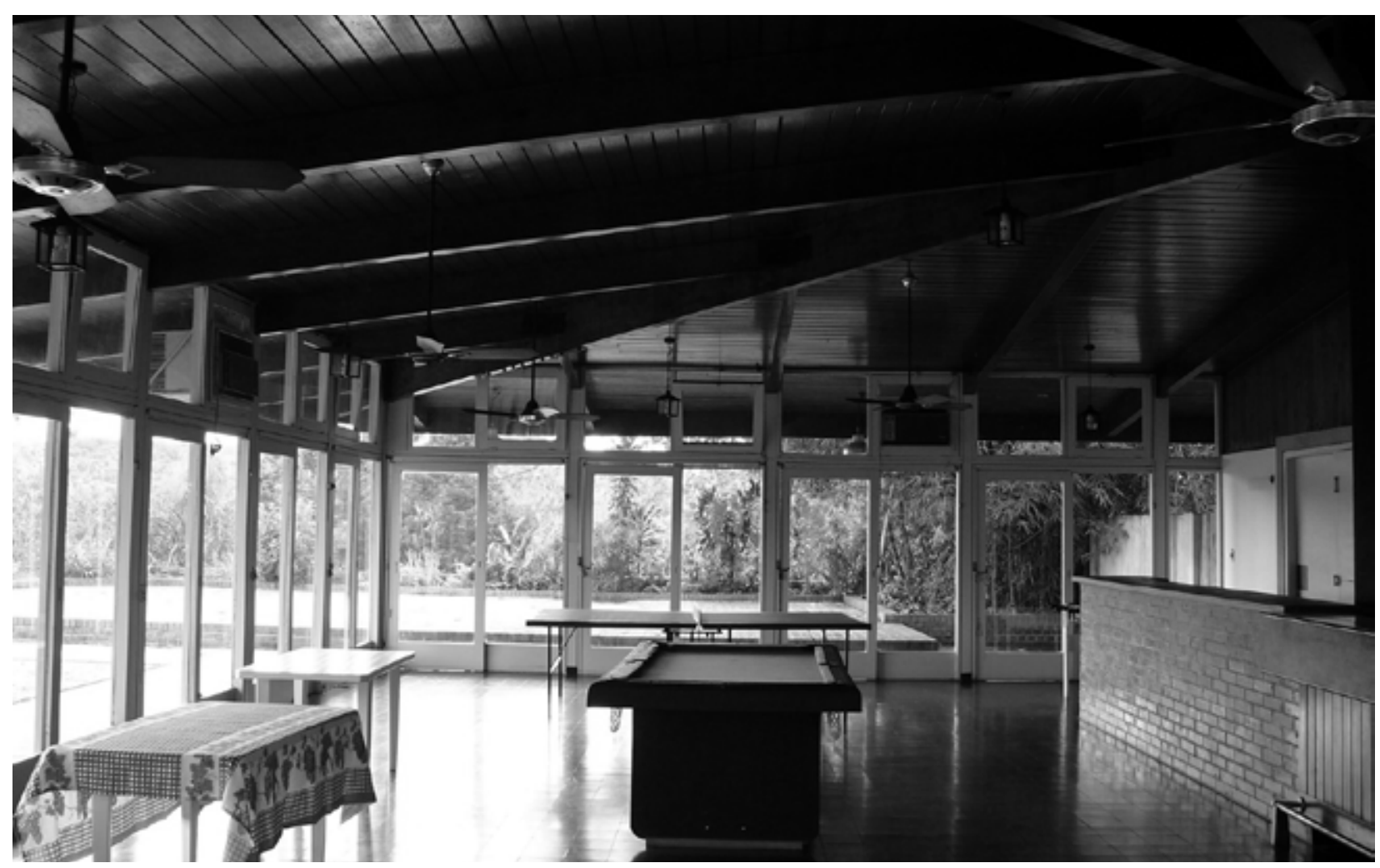

Imagen 52: Comedor Hostería en Montecarlo

105 SHMIDT, Claudia (2013). "Excepción y Circunstancia: Francisco Bullrich y la arquitectura del todo o las partes. El proyecto de la Embajada argentina en Brasilia (1970)" En 2das Jornadas de Historia y Cultura de La Arquitectura y la Ciudad; La teoría de sistemas en la transformación de la cultura urbana. Arquitectura, Ciudad y territorio entre el profesionalismo y la tecno-utopía (1950-1980). Buenos Aires. UTDT-UNL. pp.144-157. 

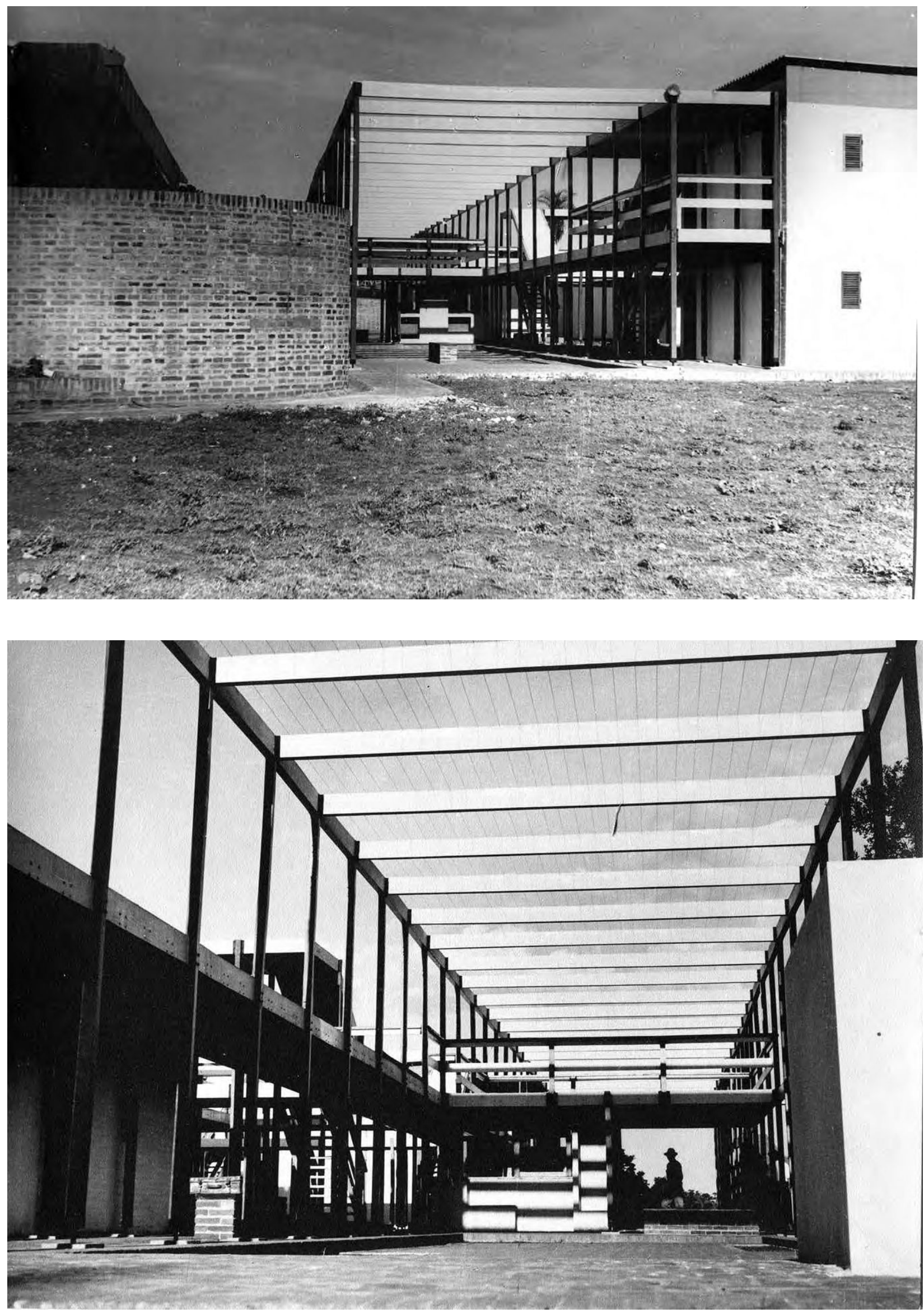

Imágenes 53 y 54: Fotografías Hosterías Apóstoles y San Javier. 


\section{Escuela Normal Número 1 en Leandro N. Alem}
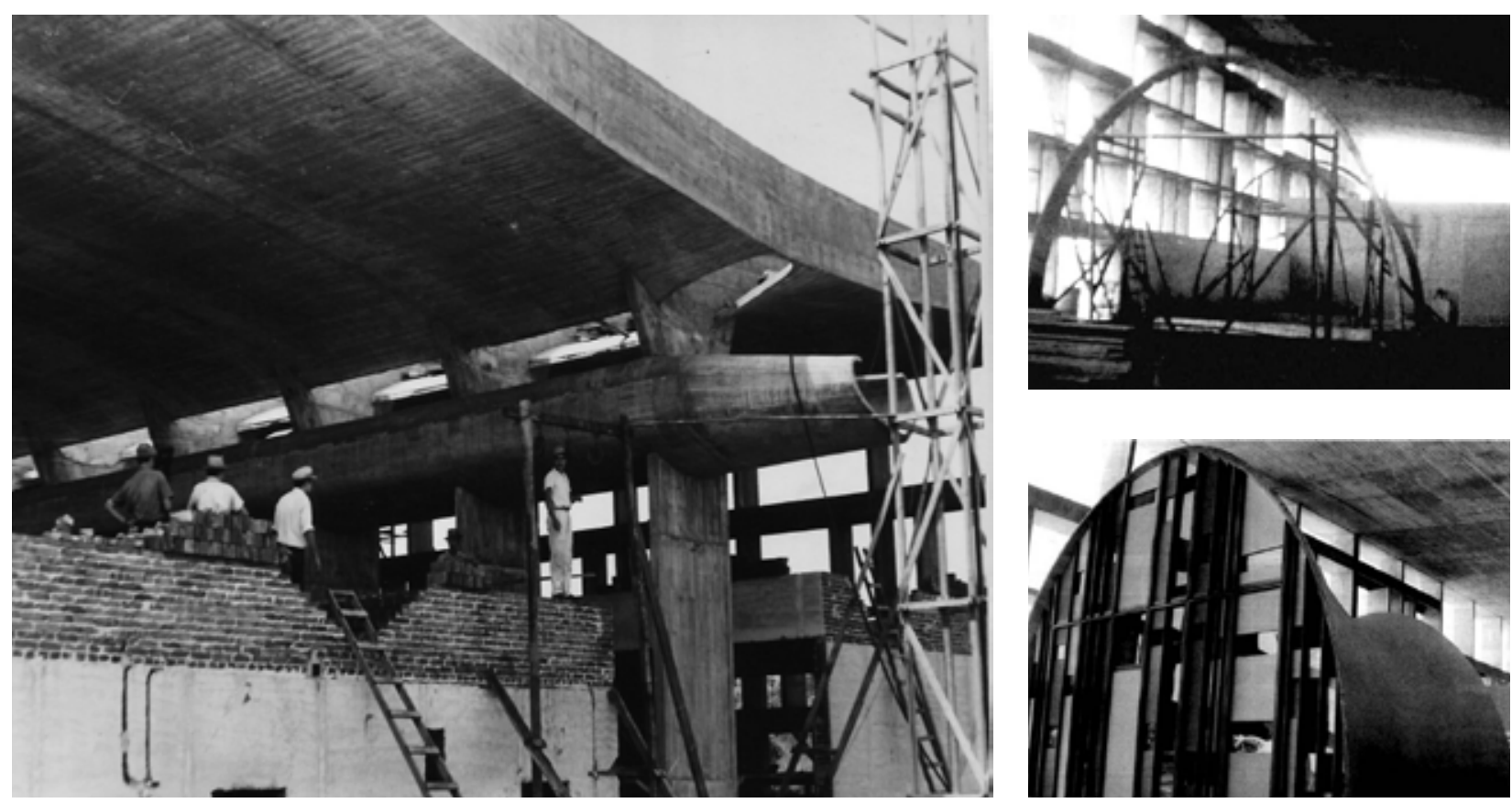

Imágenes 55; 56 y 57: Fotografía tomada durante la construcción del muro de cerramiento lateral y encofrado de cubierta; Etapas de construcción de la sala de música, desde el planteo inicial a la forma concluída

Luego de la segunda posguerra, en el marco de una reorganización institucional que priorizó el accionar del Ministerio de Obras Públicas de la Nación, las construcciones de edificios para todos los niveles de enseñanza se inscribieron dentro de un "estilo oficial", caracterizado por la fuerte impronta urbana y un marcado cambio de escala. Hacia mediados de 1950 se produjo un viraje hacia expresiones despojadas, libres de estilismos que respondían a nuevas demandas funcionales, ${ }^{106}$ reafirmando el rol modernizador del Estado y el carácter laico de la educación.

Las construcciones se inscribían dentro de las contemporáneas tendencias de la "nueva modernidad" y eran materializadas con potentes estructuras apoyadas sobre columnas, arcos metálicos o de hormigón. Hacia el final de la década de 1950 se realizaron experiencias en la Argentina, que apoyadas en ideas avanzadas cambiaron las concepciones programáticas y arquitectónicas existentes en la construcción de escuelas. Hasta ese momento la arquitectura para la educación había transitado desde experiencias inspiradas en lenguajes renacentistas y barrocos con modelos entre lo palaciego y claustral, motivados por los proyectos de Francesco Tamburini durante 1880, hasta el modelo pabellonario del arquitecto René Villeminot, a comienzos de la Primera Guerra Mundial. Más tarde los edificios escolares expresaron el lenguaje neocolonial y el art decó, para luego volcarse de lleno en 1940, a una estética de austero racionalismo, dominados por planteos geométricos. Todas estas experiencias y aproximaciones estilísticas manifiestan las distintas estrategias puestas en juego por el Estado en el camino de la construcción del "lenguaje nacional". Durante los últimos años de 1950 e inicios de 1960, las escuelas realizadas, se caracterizaron por desarrollar un alto grado de experimentación y un esfuerzo por alinearse dentro del debate estético del momento que oscilaba entre diseños de matriz naturalista y otros, en donde se hacía un uso expresivo del hormigón armado, para materializar composiciones de carácter monumental ${ }^{107}$.

106 GREMENTIERI, Fabio; SHMIDT, Claudia (2010) Arquitectura, educación y patrimonio...cit. pp.74-95.

107 GREMENTIERI, Fabio; SHMIDT, Claudia (2010) Arquitectura, educación y patrimonio...cit. pp.95-111. 
Este material, así utilizado, alcanzaba sus máximas posibilidades constructivas, espaciales y plásticas en planteos de solemne majestuosidad, con una contundencia equiparable a la edilicia tradicional. Las obras tienen un potente carácter escultórico que hace visible su tridimensionalidad.

El 9 de diciembre de 1957, en el Boletín Oficial de la Provincia de Misiones se publicaba el decreto por el que el Interventor de la Provincia, Adolfo Pomar, aprobaba el expediente 14/16 para encargar de manera directa, el proyecto y la dirección de obra a los arquitectos Soto y Rivarola, para la construcción de una escuela normal a ubicarse en Leandro N Alem, una localidad a $100 \mathrm{~km}$ de Posadas. ${ }^{108}$

Se inicia de esta manera, lo que se podría considerar, una segunda etapa en la producción del estudio, aunque en realidad lo correcto sería decir que es la primera vez que los autores materializan ideas que venían desarrollando con anterioridad. Si se consideran las experiencias de Soto, junto a Traine en Tucumán, durante la experiencia del proyecto del Hospital Ciudad de Horco Molle o la escuela de Enfermería, ejecutadas entre 1953 y 1954, dentro del marco del denominado plan de salud Carrillo, se puede trazar una continuidad tanto en la búsqueda formal como en las tentativas de usos del material. Aunque la concreción de estas búsquedas tuvo un inicio impensado. El proyecto original, surgido de un presupuesto muy ajustado, estaba concebido para realizarse con una cubierta sostenida con estructura de madera y chapas de fibrocemento como cerramiento. La ampliación de la partida con que contaba el Ministerio de Economía y Obras Públicas para la realización de la obra y la voluntad del interventor Pomar ${ }^{109}$, permitió realizar el cambio, tanto del techo como de la estructura, lo que provocó la reconversión del proyecto para el edificio, brindándoles unas condiciones inmejorables para la concreción de especulaciones materiales que formaban parte de las búsquedas de la oficina.

Estas experimentaciones serían comentadas por Francisco Bullrich (1969) en el libro Arquitectura Latinoamericana 1930/1970, cuando señalaba:

Que a partir de 1960 pareciera estargestándose en Argentina una tendencia arquitectónica que si bien no siempre presume una identificación de puntos de vista y por lo tanto no constituye un movimiento, surge de un mismo deseo de liberarse definitivamente del diccionario cubista y sus implicaciones ulteriores. En general la tendencia de la joven generación argentina pareciera ser el alejamiento de configuraciones espaciales simples, con su consecuencia inevitable, una estereometría pura, la ideación de estructuras en hormigón que expresen la plasticidad de este material y un modo más expresivo en el tratamiento de los materiales a su disposición.

Para la nueva generación, el término arquitectura moderna no se identifica necesariamente con los aspectos polémicos de la arquitectura de preguerra y sus integrantes creen que los esquemas del racionalismo deben ser superados con el objeto de encontrar soluciones más acordes con las nuevas circunstancias. En muchas obras realizadas entre 1958 y 1962 se apeló al hormigón en bruto y a soluciones crudas y directas configurándose una suerte de neo-brutalismo. El abandono de la tecnología más moderna hasta entonces, estimada un prerrequisito de toda nueva arquitectura fue considerado necesario a los efectos de ajustar los planteos técnicos a la nueva realidad del país. ${ }^{110}$

108 Ver anexo (imág.80-81-82-83-84-85-86-87).p.49/55.

109 Ver anexo. Nota Número 55 Letra “C” Año 1958. M.E y O.P.(imág.84-85-86-87).p.49/55.

110BULLRICH, Francisco(1969): Arquitectura latinoamericana 1930/1970. Buenos Aires. Ed. Sudamericana .p.31. 
Este último párrafo escrito por Bullrich, capta y sintetiza con total exactitud la práctica desarrollada por Soto y Rivarola. Como hemos visto, la concreción de sus proyectos, se ha realizado mediante la utilización de técnicas constructivas tradicionales en combinación con el uso de materiales simples, aunque incluidos de manera novedosa, constituyendo un lenguaje que combinó profesionalismo con experimentación, un ejercicio sobre el que Soto y Rivarola, edificaron su experiencia.

Es interesante retomar en este punto el recorrido transitado por el proyecto y en las transformaciones que le impuso el cambio de material de su cubierta, al pasar de una estructura de madera con cerramiento de chapas de fibrocemento a una cubierta de hormigón de una forma y materialización tan particular. ${ }^{111}$

Efectivamente, la posibilidad de analizar los distintos y sucesivos proyectos plasmados para la misma escuela, con las modificaciones practicadas, más las fotografías de la obra concluida, permiten desandar el camino trazado desde las primeras y más borrosas ideas, hasta la materialización definitiva. Es tal vez una de las instancias más crudas, en donde el pensamiento y la ideación del proyecto se manifiestan.Así de la observación de los primeros planos surge la certeza de que la obra de la escuela en Leandro N. Alem, no solo marca un cambio en la producción del estudio sino también un salto en la trayectoria del pensamiento arquitectónico de sus autores.

Los primeros planos y dibujos muestran una primera planta que en principio no difiere demasiado con la del proyecto definitivo. Sin embargo donde realmente las diferencias se hacen notorias, más allá de la obvia discrepancia de las dos cubiertas, es en los cortes y en las fachadas.

El primer proyecto, proponía para la cubierta un sistema compuesto por una estructura de madera; por la luz que debían cubrir, aproximadamente 13 metros, presumiblemente se utilizarían vigas de madera laminada o piezas metálicas, y una cubierta de chapas de fibrocemento por encima. La misma sería a dos aguas con la inclinación hacia adentro. ${ }^{112}$ Con una forma asimilable a una "V" contenía en el vértice, conformado por la unión de ambos planos, una canaleta para el escurrimiento del agua de lluvia. La dimensión prevista para los desagües era por demás deficiente, teniendo en cuenta no solo la superficie a desaguar sino el volumen de lluvias que se precipitan en la región, la solución propuesta, se presentaba de un modo casi ingenuo. Es un aspecto que vincula fuertemente al proyecto con una práctica más estudiantil que profesional (es conveniente recordar que Rivarola había egresado de la Facultad de Arquitectura de Buenos Aires en 1954 mientras que Soto, lo había hecho en 1956 apenas unos años antes del encargo del proyecto). Las modificaciones en el cambio de estructura, encomendado por el gobierno de Misiones, ocasionaron la transformación, no solo en la solución particular de la cubierta y sus sistemas de sostén y desagüe, sino en la habilidad proyectual de sus autores. Entre los primeros planos y los definitivos, median apenas 8 meses. ${ }^{113}$ Sin embargo la estructuración y desarrollo del segundo proyecto manifiesta una evolución notable. Los dibujos hechos para el estudio de la cubierta, como los confeccionados para la realización del encofrado expresan un alto grado de conocimiento, no solo de aspectos propios de la disciplina, sino también de sus procesos constructivos. Y si bien sus autores, ya habían dado muestra de un particular talento para el desarrollo material del proyecto, en el caso de las escuelas y las hosterías, las mismas respondían a una tecnología, evidentemente más sencilla como es la madera.

111 Para mayores precisiones acerca de las circunstancias del cambio de material de la cubierta ver anexo, Pág. 11

112 Ver anexo (imag.88-89). p.55.

113 Los planos del primer proyecto llevan en el rótulo la fecha enero de 1958; los del proyecto definitivo tienen la fecha: $25 / 8 / 1958$. 

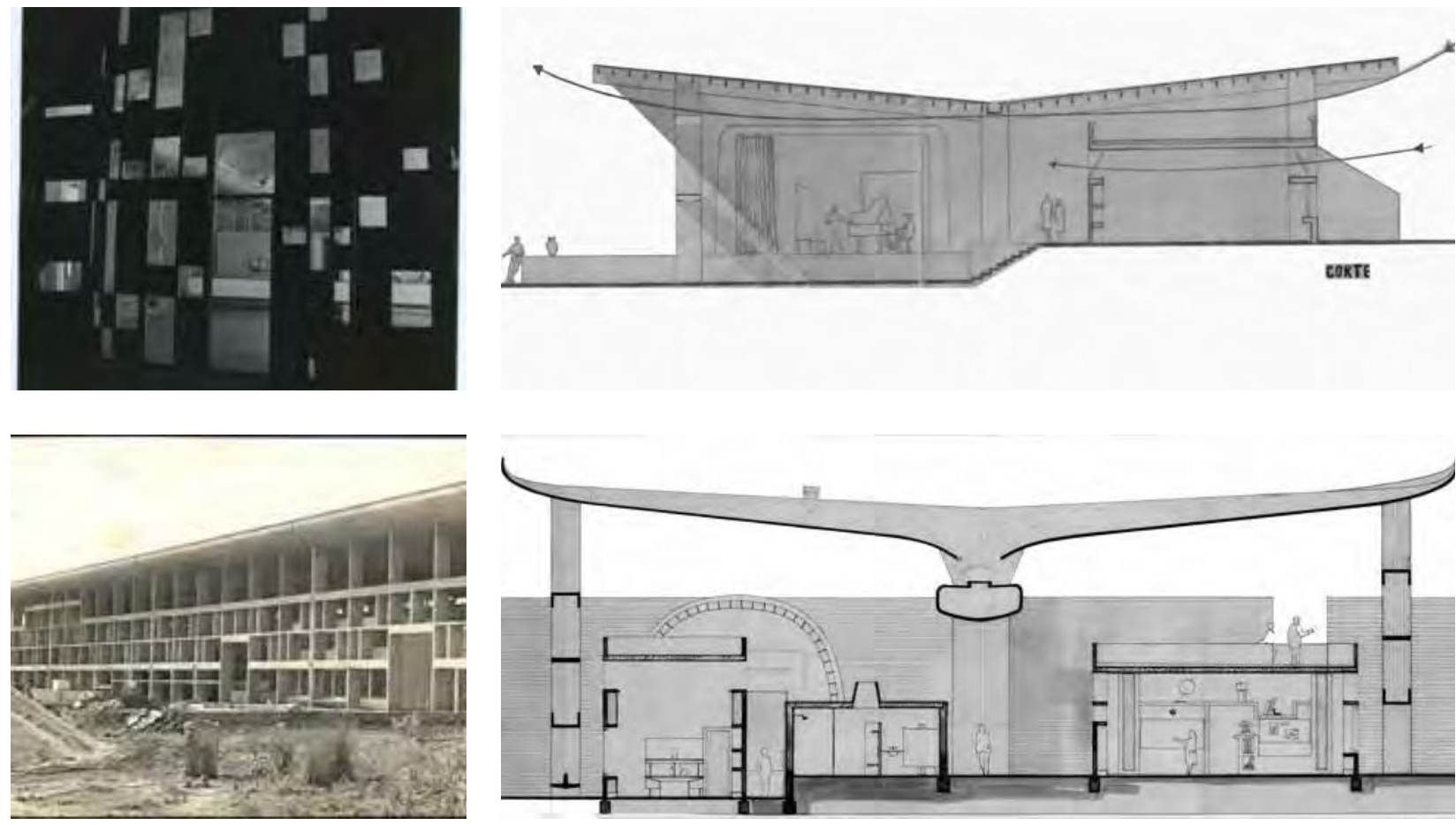

Imágenes 58; 59; 60 y 61: Fotografía del interior de la sala de música; corte del proyecto original, con cubierta de estructura de madera; Fotografía de la fachada principal durante la construcción, Corte definitivo con cubierta de Hormigón Amrmado

En este caso en particular, no solo se incorporaba un nuevo material al repertorio formal manejado por la oficina, en lo que a soluciones estructurales se refiere, sino que se lo explotaba también en sus aspectos expresivos. Bullrich (1969) señala:

en la Escuela en Leandro N. Alem, lo interesante del trabajo, es que sus autores han sabido extraer de los problemas prácticos y constructivos un producto de un vigor plástico sugestivo y de una calidad bastante más compleja, de lo que la lectura de la planta permitiría suponer. Los distintos cuerpos ubicados bajo el gran techo entablan un diálogo de forma, profundidad y proporción variable desde los distintos puntos de vista posibles para el observador. ${ }^{114}$

La conformación de la cubierta-estructura de hormigón fue realizada con particular cuidado y dedicación, procurando, con éxito, exaltar las capacidades plásticas y expresivas del material. Todo esto, recordará Rivarola durante las entrevistas realizadas en el marco de la presente investigación, fue posible por el esfuerzo compartido de todos los integrantes del estudio, que comprometidos en la creación colectiva hicieron factible su materialización. Fueron los precisos cálculos del arquitecto Alfredo Yantorno, o los dibujos casi obsesivos realizados por Carlos Laprovítola para el armado de los planos de encofrados de la losa, o los del mismo Soto, hechos a mano alzada para la construcción del sistema de parasoles, los que cristalizaron en la forma definitiva.115

114 BULLRICH, Francisco (1969) Arquitectura latinoamericana...cit.p.54. 
La transformación impuesta por el cambio del material estructural, también se vio reflejada en la modificación del sistema de parasoles y muros laterales. Así los dibujos del primer proyecto, acompañado de la memoria descriptiva dan cuenta de la existencia de pilares realizados con muros portantes, unidos mediante losas de hormigón, que ofrecían un frente semi-permeable, con gruesos bloques de mampostería, dispuestos de manera casi simétrica en torno al eje perpendicular de acceso, dejaban expuesta una trama cuadriculada, con profundos huecos, fruto de la alternancia de pilares y losas. Sobre estos pilares se ubicaban de manera perpendicular, las vigas de soporte de la cubierta, que tenían importantes voladizos en ambos lados del edificio, aunque de un resultado formal, relativamente débil, ocasionado, principalmente por la esbeltez de los distintos elementos. ${ }^{116}$

El segundo proyecto, en cambio, presenta una transformación radical, en el diseño de todo el conjunto de fachada. Principalmente la desaparición de los bloques profundos de mampostería. Al aparecer los pilares de hormigón, las funciones ubicadas en los bloques de ladrillo, que antes daban al exterior se receden, generándose un espacio de transición entre el interior y el exterior. El conjunto de pilares fue reemplazado por una trama de menor sección de elementos de hormigón armado, que con la alternancia y el ritmo de sus piezas muy estudiado, propuso una relación exterior-interior de mayor transparencia, permitiendo exaltar el juego de los volúmenes dispuestos libremente bajo la gran cubierta, que ahora aparece como una gran cenefa dándole al conjunto un remate de mayor potencia formal. ${ }^{117}$ Otro punto, que brinda aspectos interesantes del proceso proyectual, es el diseño y transformación experimentada por la sala de música. En su proceso de ideación es posible observar el paso de la forma ideada hacia la idea construida. Recorrido éste, siempre condicionado, tortuoso, nunca lineal y de desenlace impredecible.

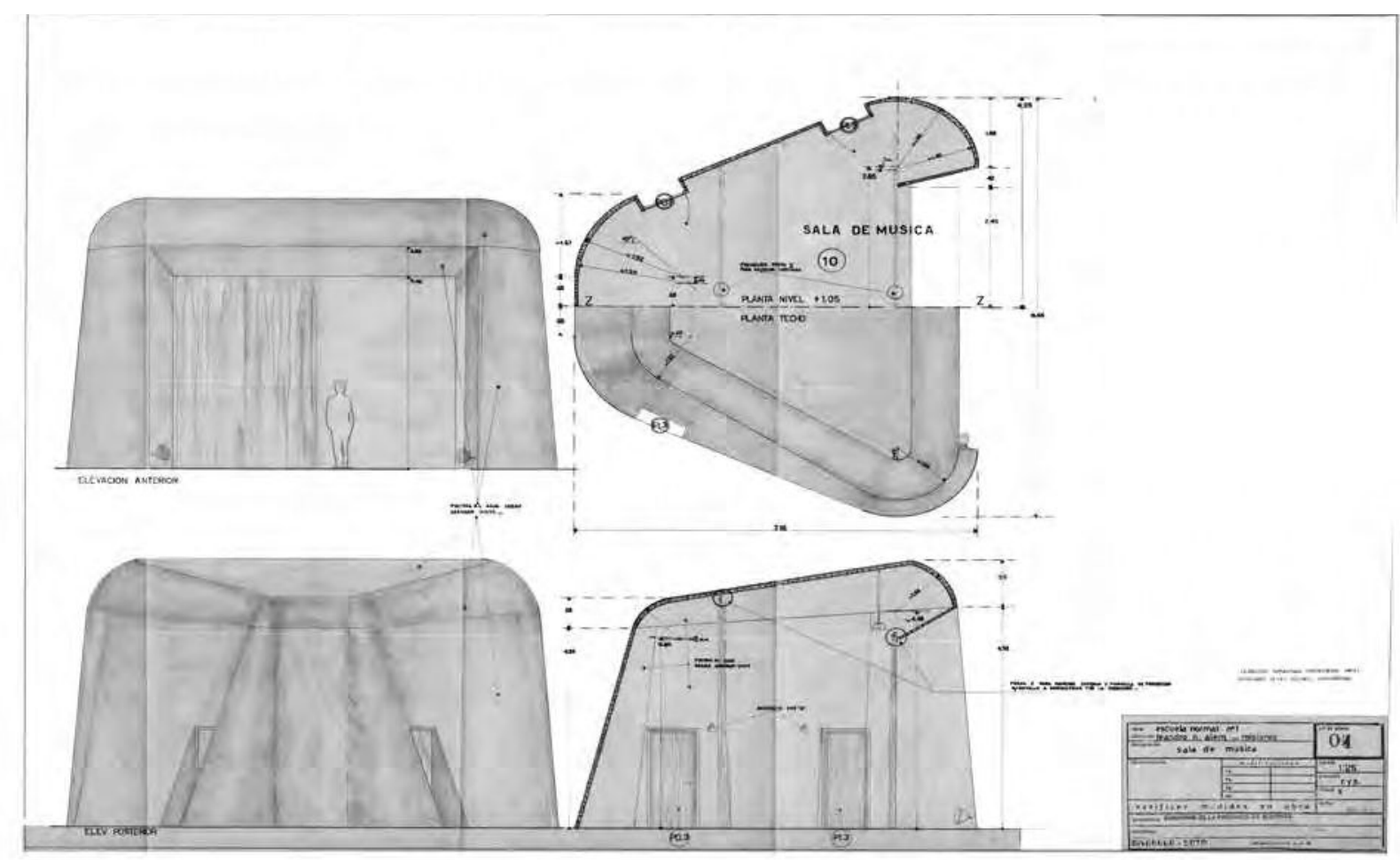

Imagen 62: Dibujo realizado por Mario Soto, identificado con la Letra O4, en donde se estudia una primera resolución para la sala de música

116 Ver anexo apartado "Primer proyecto" (imág.92-93).p.57.

117 Ver anexo apartado "Segundo proyecto" (imág.95-96).p.58/59. 
La ubicación dentro de la planta de conjunto, se mantuvo inalterable a lo largo de las diferentes propuestas: siempre dispuesta sobre el ala izquierda del patio cubierto, cerrando el lado menor del rectángulo conformado por las gradas y escalinatas, el acceso a la escuela y las funciones administrativas. ${ }^{118}$ El conjunto forma un rectángulo cuyos lados mayores tienen una longitud de $18.875 \mathrm{~m}$ y los menores $13 \mathrm{~m}$. En este punto de la planta, las distintas grillas geométricas manifiestan su mayor grado de libertad. Al ritmo impuesto por los pilares de hormigón separados cada 3.50m unos de otros, se le superponen las distintas líneas que surgen de las medidas de las cajas que quedan sueltas en ese espacio. La sala de música siempre cumplió con la función de ser un espacio flexible y de ese modo puede utilizarse como aula o mediante la apertura de una de sus caras, gracias a un sistema de carpinterías rebatibles, en continuidad y relación con el mencionado patio cubierto, oficiar de escenario. Pero éste es el único rasgo inalterado de la sala, mientras que la forma general fue centro de múltiples pruebas y modificaciones.

Uno de los primeros planos, el identificado con la letra A1 de enero de 1958 dibujado por Rivarola, muestra un primer diseño de sala, perteneciente al proyecto inicial que contaba con estructura de madera, con una geometría casi regular, apenas una pendiente en la cubierta dando mayor altura al extremo que queda vinculado con el patio-auditorio. Estaba prevista su construcción con hormigón armado in situ. Una única envolvente de $20 \mathrm{~cm}$ de espesor aproximadamente, cerraba tanto los laterales como la cubierta. ${ }^{119}$

El conjunto de planos posteriormente realizados, (identificados como: G2, dibujado por Rivarola y con fecha: Marzo de 1958; O4 dibujado por Soto, con fecha: marzo de 1958 y el E3 sin fecha ni identificación del dibujante, pero incluido en esta serie), exhiben una drástica modificación de la geometría y participan de la misma voluntad formal y técnica. Se trata de una superficie de doble curvatura, difícilmente asimilable a
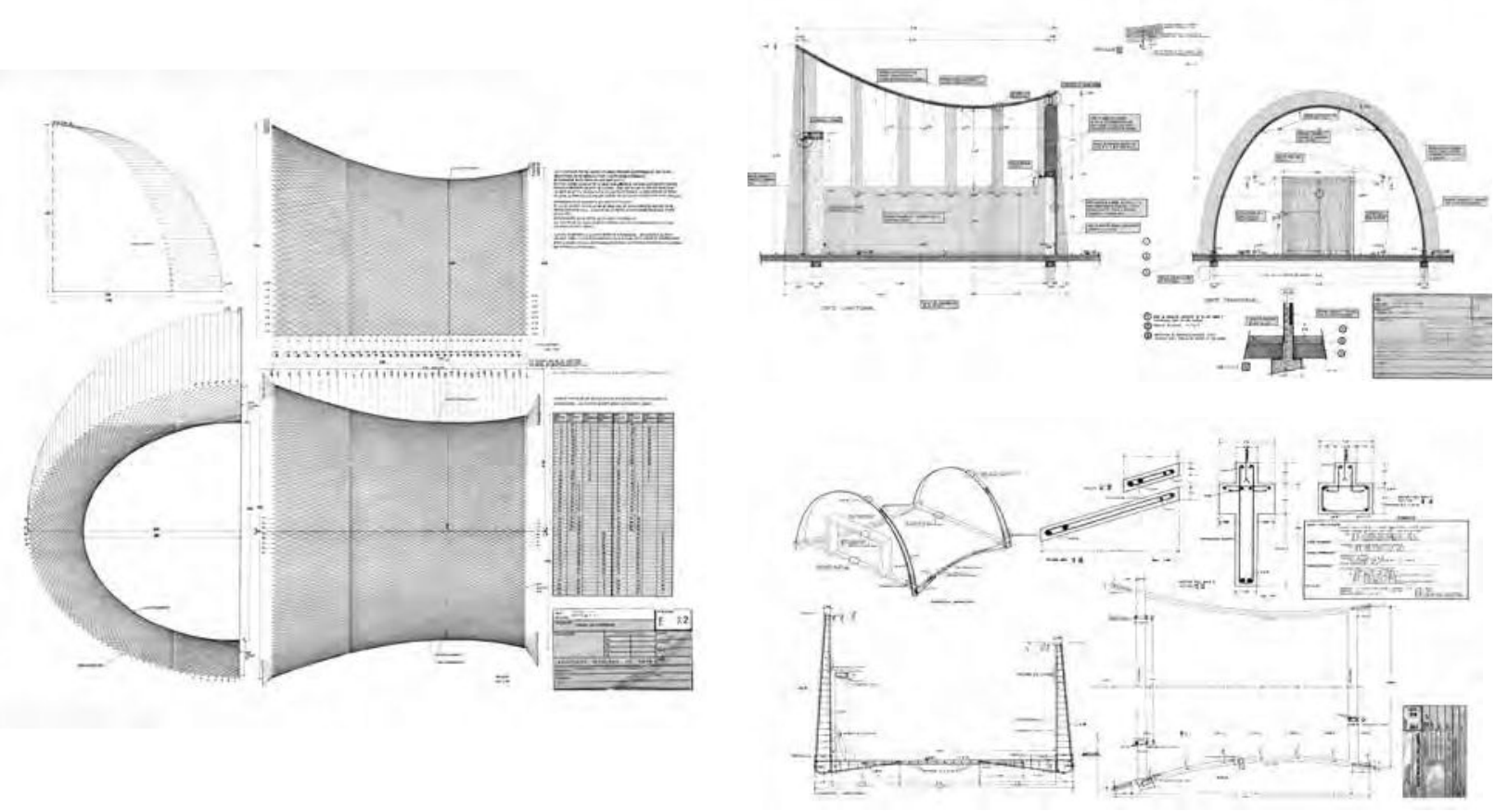

Imágenes 63; 64 y 65: Plano de armadura estructural de la sala de música. Dibujado por M. Golubof, identificado con la Letra $\mathrm{E}$ 32. Corte longitudinal y transversal de una versión preliminar de la sala de música, identificada con la Letra 011, Corte, detalles constructivos y esquema en perspectiva, para el armado de la sala de música, identificado con la Letra E29

118 Ver anexo apartado (imág. 97-98).p.59. 
las superficies regladas o de revolución más comunes. Vista en planta podría sintetizarse en un triángulo isósceles con los vértices redondeados, mientras que la vista lateral, por el lado largo, tiende al trapecio, la cara que oficia de boca de escenario es casi un rectángulo. ${ }^{120}$ De anchos variables, las distintas caras de la envolvente están proyectadas para ser realizadas con una cáscara de hormigón armado, de $9,5 \mathrm{~cm}$ de espesor para la resolución del plano horizontal y unas membranas de $3.5 \mathrm{~cm}$ de espesor para los cerramientos laterales. La planta sobrepasa la medida que el doble módulo de $3.5 \mathrm{~m}$ parecerían imponerle sobre el eje longitudinal, mientras que en el otro sentido, el ancho de la boca de escena es mayor que el del fondo.

La sucesión de planos identificados con las letras E29; O10; O11 y el E32 todos sin fecha y sin especificar el dibujante, pero claramente de confección posterior a los anteriores, ya expresan una geometría más próxima a la definitiva. El paraboloide hiperbólico, parece haber ido ganando protagonismo y se ha impuesto por sobre los anteriores desarrollos. En cambio la resolución material propuesta sigue siendo el hormigón armado colado in situ como cerramiento exterior, aunque se suman unos muros de ladrillos comunes de $30 \mathrm{~cm}$ de espesor, que resuelven la cara interior de la sala. Ahora no es entendida como una pieza única, ya que el plano superior está conformado por una cara de menor espesor, materializada mediante una membrana armada de concreto que sigue la forma de la cúspide de la "silla de montar", articulando su unión con los cerramientos laterales mediante unas piezas de vidrio de las denominadas Glass Block de $10 \mathrm{~cm}$, asentadas sobre concreto. ${ }^{121}$ Es importante el avance experimentado en el desarrollo puesto de manifiesto en esta nueva serie de planos, ya que aquí se puede encontrar el inicio de la forma definitiva. La resolución final de la sala de música, seguirá la geometría expresada en estos dibujos, aunque la materialización de la totalidad de la envolvente continuará el criterio propuesto para el cerramiento superior. Así la morfología se concretó mediante la colocación de dos arcos paralelos, de distinta medida. Disponiendo una serie de alambres tensados que hicieron de soporte de una malla metálica, sobre la que se aplicaron manos de concreto arrojado, sin fratachar y de terminación rústica. El recorrido descripto permite desandar el camino de la ideación arquitectónica y estudiar las transformaciones impuestas a la forma por la tecnología disponible, la resolución material y estructural adoptada. Dejando expuesta la desintegración definitiva del binomio forma y función ${ }^{122}$, desarrollando una búsqueda que aunó invención, tecnología y experimentación.

La nueva cubierta de hormigón constituye por sí sola, un tema que merece un tratamiento detallado. Los planos de cortes y los bocetos confeccionados, como así también los planos de detalle, dan cuenta del profundo estudio realizado para su ejecución. Formada por una sucesión de "costillas" que como perchas invertidas, se apoyan en tres puntos, en el centro y en cada extremo. Conforman una pieza que mantiene cierta similitud con la que pocos años después utilizarían en el Banco de Londres los arquitectos Sánchez Elia, Peralta Ramos y Agostini (SEPRA) junto a Testa. La disposición en paralelo de estos soportes es atravesada por una trama, de geometría "libre" que en sentido perpendicular los vincula conformando una grilla que de manera solidaria, se unifica para soportar las cargas. Por debajo y colgada de ella se ubica la losa, cuya sección es fácilmente asociable a la forma de dos alas, que confluyen apenas por encima del apoyo central, dejando por debajo de ellas, una canaleta corrida, que a la manera de una gran cisterna recolecta y almacena el agua de las lluvias teniendo dos desbordes en cada extremo, que son resueltos de un modo escultórico.

120 Ver anexo apartado "Escuela Leandro. N Além, planos" (imag.101).p.61

121 Ver anexo apartado "Escuela Leandro. N Além, planos" (imag.102).p.61

122 Para un desarrollo más profundo de este concepto ver: VIDLER, Anthony (2008) Histories of the inmediate present. Inventing architectural modernism Cambridge (Mass) MIT Press. pp. 20-155. 
Trazando una relación, que en simultáneo se llevó a cabo en varios edificios de Brasilia ${ }^{123}$, donde se materializó, con la utilización de formas plásticas, la ejecución de los desagües pluviales.A partir de aquí puede verificarse un paulatino alejamiento de Soto y Rivarola del concepto de prototipo, reformulado sobre la base de lo indeterminado y del crecimiento infinito, para comenzar a desarrollar una arquitectura que se concretó a partir de lo específico y lo singular. La escuela obtuvo un sello distintivo de fuerza expresiva en su exterior y una espacialidad cautivante en su interior. La cara interna de la cubierta manifestó toda la carga plástica del tratamiento en bruto del material, que acrecentada por la escala, la altura y la distancia que mediaba entre ella y los volúmenes cubiertos, conformó un conjunto de enorme valor para la arquitectura.

Finalmente, toda la operación de Alem debe ser tenida en cuenta como un episodio que entrecruza variados argumentos. La escala de la escuela es monumental para la dimensión del pueblo. El solar, dos manzanas unificadas, brindaba el marco adecuado para el carácter simbólico que se esperaba del edificio.

La condición de escuela "normal", provoca otro tipo de reflexiones; el Estado pretendía conformar un centro de formación de maestros primarios, profesores secundarios y magisterio rural, buscando producir una transformación integral de la estructura urbana y poblacional de Alem. Estas estrategias obedecían a planteos puestos en práctica en muchas ocasiones por el gobierno, el Ministerio de Obras Públicas y las distintas reparticiones responsables de la ejecución de los establecimientos escolares, para desplegar una acción de desarrollo y crecimiento territorial.

La organización de la propuesta de la escuela mantiene ciertas continuidades con la tradición en materia de establecimientos educativos. Un sistema de doble crujía ubica en una de las franjas: las aulas bien iluminadas y ventiladas; en la otra: las funciones administrativas, de servicio y auditorio, intercalando el patio cubierto y el acceso principal al edificio; planteo largamente utilizado en la arquitectura escolar. En cuanto a la morfología, la relación con las construcciones realizadas por Le Corbusier en Chandigarh surge inevitable, pero los aspectos cruciales que ilumina la comparación no deben concentrarse sobre los temas formales, sino en los simbólicos representativos. No puede soslayarse la función que desarrolla cada edificio: mientras el construido en la India, fue realizado para contener al Palacio de Asambleas, el erigido en Alem, cobija a la "escuela normal". De este modo, el "carácter palaciego" que expresa el edificio traza un lazo de permanencia con el pasado, manifestado en las realizaciones de "arquitectura civil" en aquel concepto identificado por Shmidt en su libro Palacio sin reyes (Arquitectura pública para la capital "permanente" Buenos Aires 1880-1890), pero que surge aquí con absoluta potencia, resignificado en clave moderna .

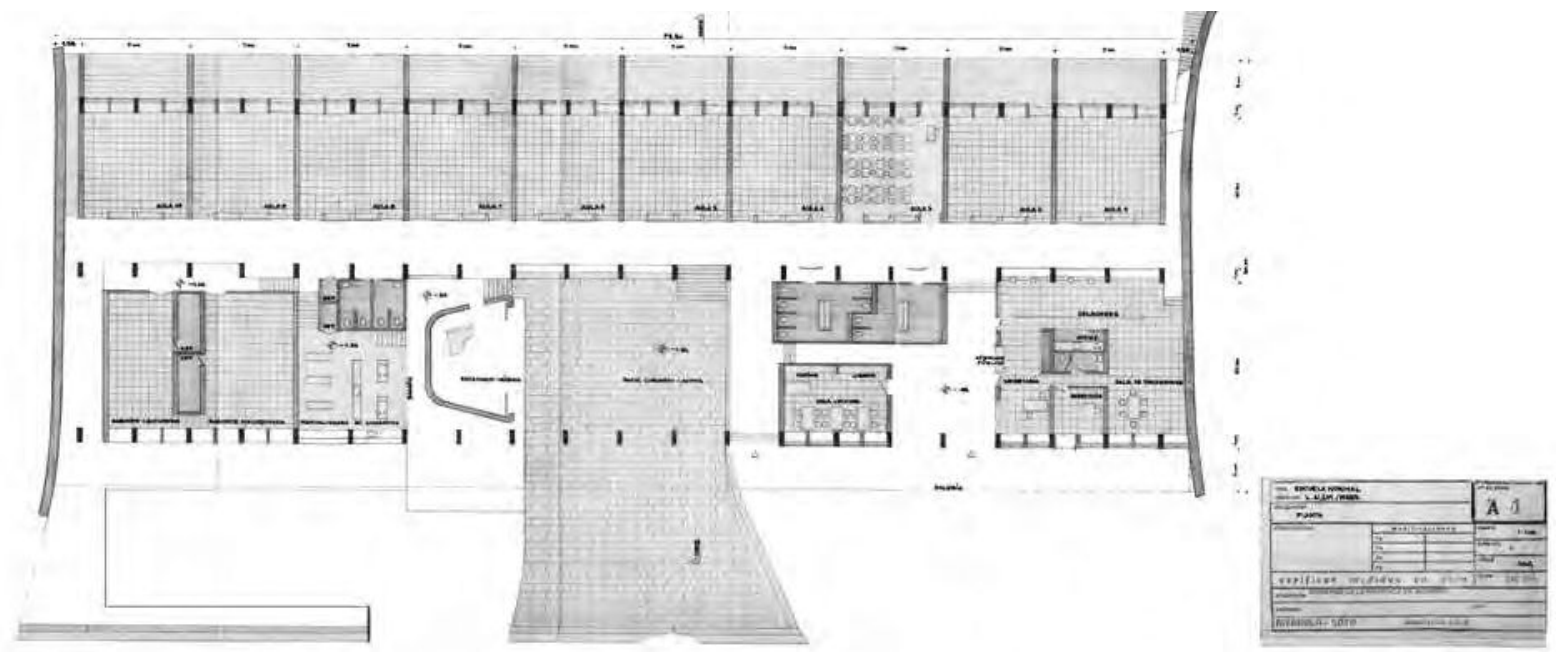



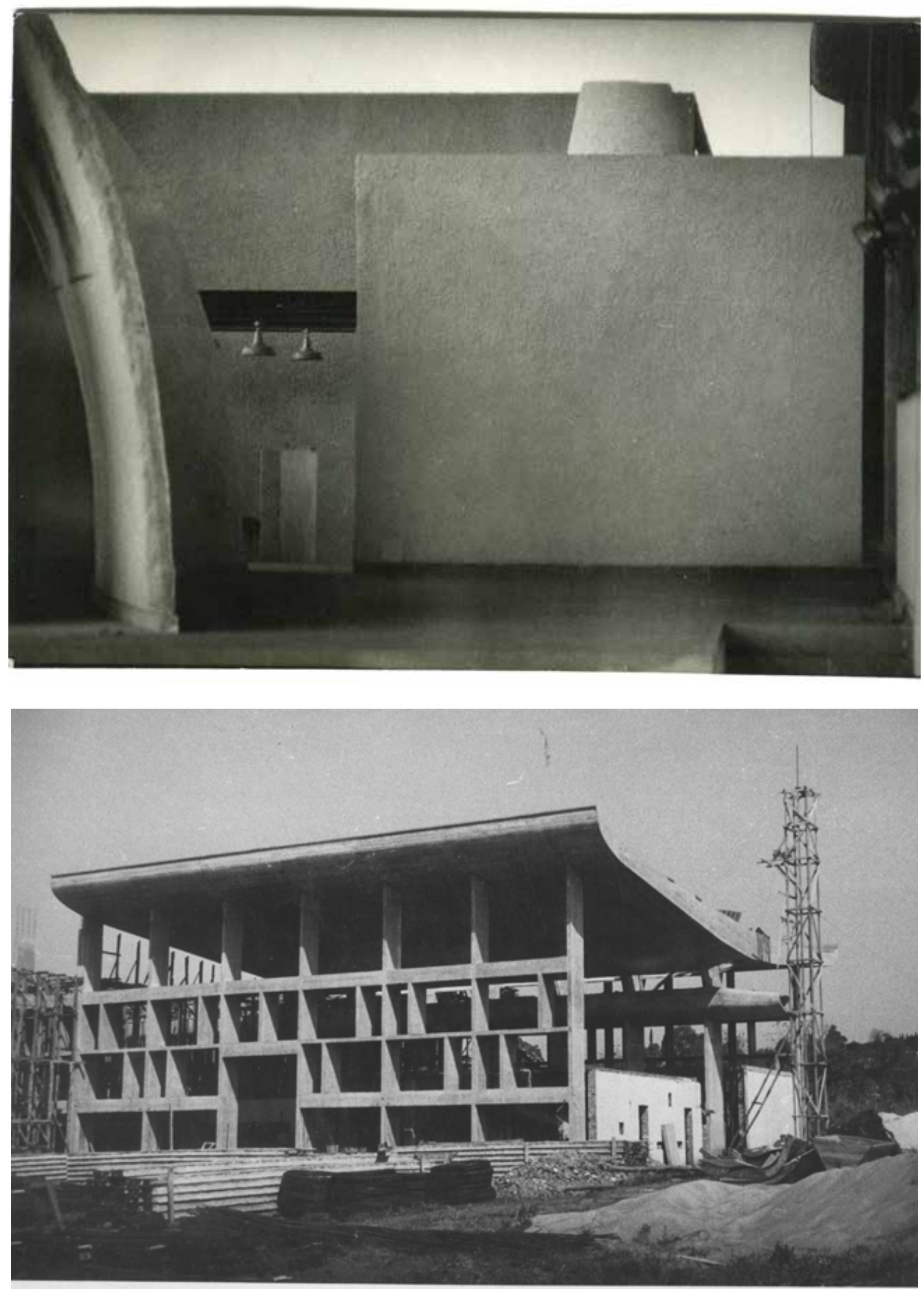

Imágenes 67 y 68: Fotografía tomada desde el interior de la escuela, observándose el lateral de la sala de música y hacia el fondo los muros que dividen los sanitarios. Fotografía de la fachada principal durante la construcción. En página anterior, imagen 66: Planta del proyecto definitivo de la escuela. 

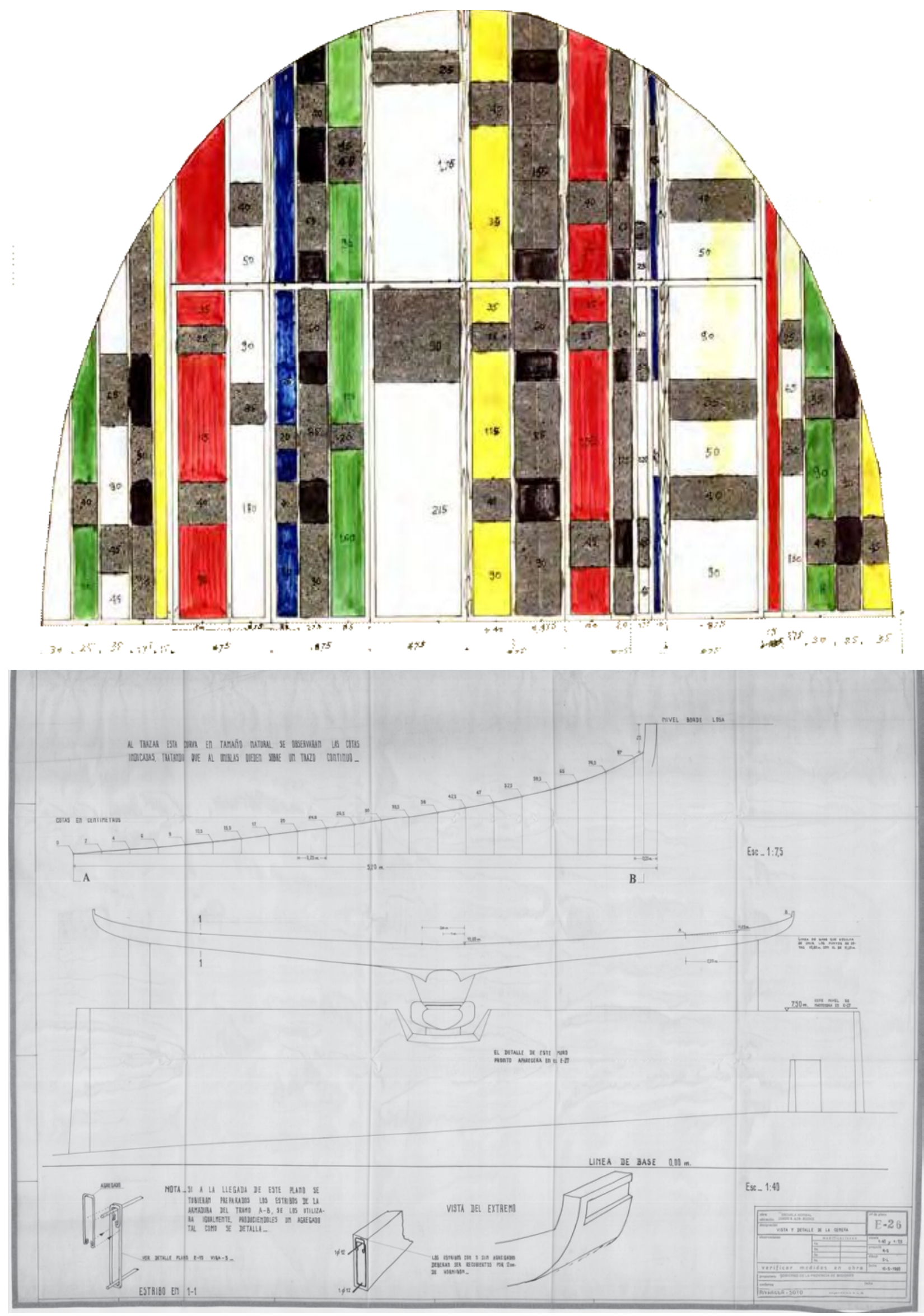

Imágenes 69 y 70: Estudio para el frente y cerramiento de la sala de música, Estudio y detalles para la resolución de la cubierta 


\section{Instituto de Previsión Social y hotel en Posadas}
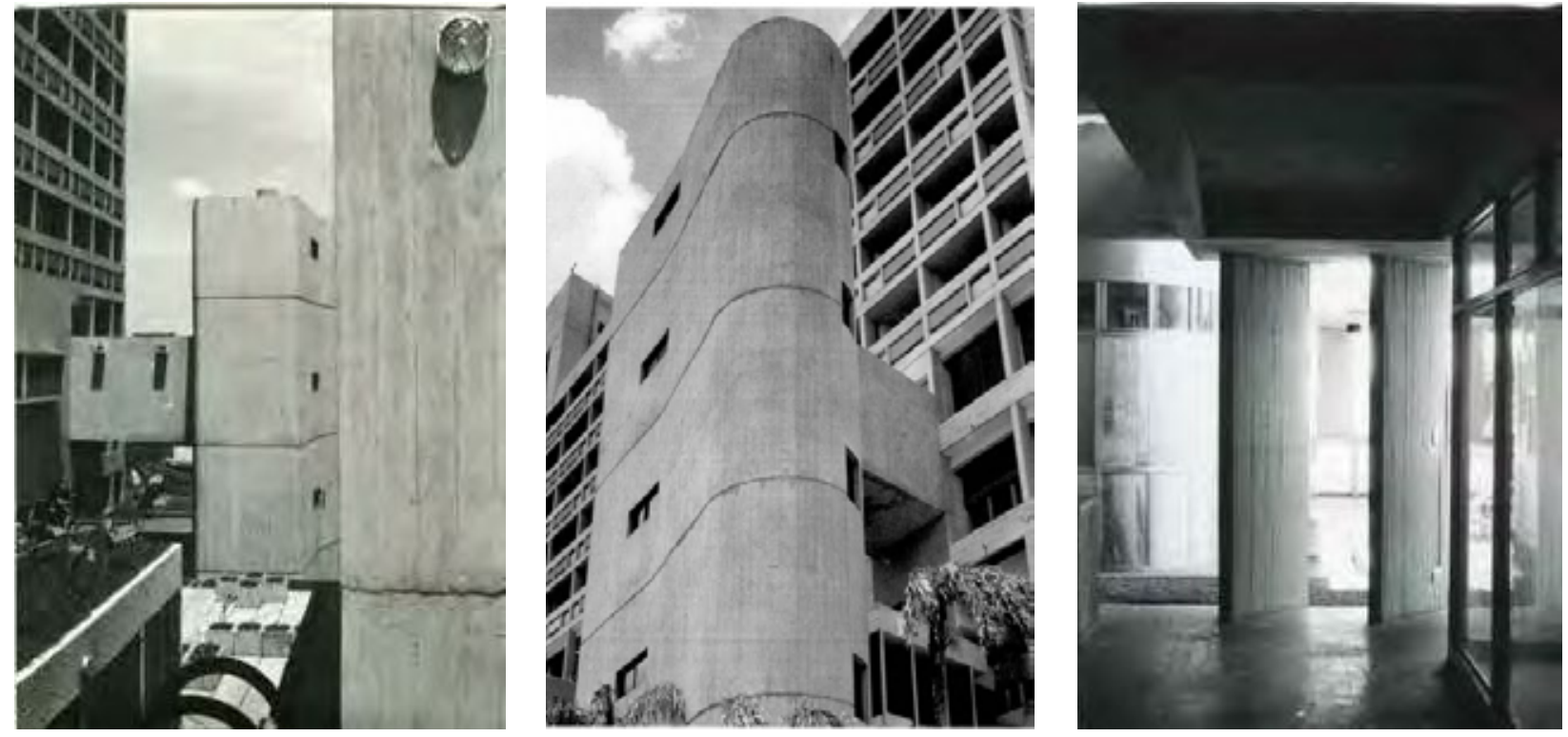

Imágenes 71; 72 y 73: Instituto de Previsión Social de Posadas, Misiones.

En el año 1959 las autoridades del Instituto de Previsión Social de Misiones, tomaron la decisión de construir un edificio para su sede en Posadas. El programa establecía la ubicación de las oficinas del IPSM, un cuerpo de hotel, una galería comercial, un restaurante y una confitería. El anteproyecto de la obra fue objeto de un concurso regional, en el cual se presentaron ocho trabajos, resultando ganador el de los arquitectos Soto y Rivarola. ${ }^{124}$

El jurado conformado por los arquitectos David Berjman, Raúl O. Grego y Mauricio Repossini, ponderó la resolución producto de un partido claro, desarrollado en un volumen unitario, que configuraba un bloque y establecía una relación adecuada con el edificio de correos, colindante. El aspecto más valorado fue "el manejo del espacio interior, enriquecido por la disposición de medios niveles, que en relación con la calle, configura un espacio de indudable interés." ${ }^{125}$

Los autores, por su parte, mantenían el mismo planteo conceptual en el armado de la memoria descriptiva, ya exhibida en los concursos anteriores, pero demostrando la experiencia ganada en estos años de intenso trabajo. Se iniciaba con la descripción del sitio a partir de sus condiciones climáticas, para luego ingresar en el análisis del paisaje y de las actividades propias del ciudadano misionero en la zona central donde debía implantarse el edificio. ${ }^{126}$ Se enumeraban los problemas funcionales detectados y las soluciones adoptadas, para finalizar con un apartado que describía el sistema constructivo a emplearse. El edificio desarrolla un programa tan variado como complejo, originado en el pliego del llamado a concurso ${ }^{127}$, reuniendo en un único solar de 30,00mts por 40,00mts a un hotel, una galería comercial, el Instituto de Previsión Social de Misiones con biblioteca y una confitería.

124 Summa $\mathrm{N}^{\circ} 8$ de octubre de 1963. pp. 37-46.

125 Ver Anexo, Fallo del jurado (imag.119-120).p.69.

126 Ver Anexo; Memoria descriptiva de los autores. (imag.121-122).p.71.

127 Ver Anexo: Programa de necesidades dentro de las Bases y condiciones. (imag.121-122-123).p.71/72. 
Para los arquitectos, la obra, fue el primer desembarco en el espacio urbano, ya que hasta aquí sus obras se habían desarrollado sin las condiciones que impone la ciudad, encontrándose ante el desafío de ubicar un edificio complejo dentro del entorno construido del centro de Posadas.El terreno ubicado en la esquina de la intersección de las calles Bolívar y Junín, contaba con ambos lotes linderos ocupados, siendo uno de ellos el Edificio del Correo, obra de importantes dimensiones, proyectada por la Dirección de Arquitectura de la Dirección General de Correos (1960), de fuerte expresión formal, cargaba de condicionamientos (en tanto la mirada sensible los percibiera) al proyecto de la nueva sede del IPSM.

Se puede analizar el proyecto desde múltiples planos, arrojando la lectura de cada uno de ellos diversas apreciaciones. Así por ejemplo, el estudio de la planta revela una toma de posición, relativamente equivalente, con respecto a las medianeras. La disposición de una entrada de servicio oficia de espacio de separación de las construcciones vecinas. Sobre uno de los lados la distancia es mayor lo que permite ubicar una rampa de tres tramos. Sobre el otro una angosta escalera de servicios, exhibe el mismo argumento proyectual: ofrecer un vacío que se propone como mediación entre lo ideado y lo existente. Desde calle Junín, una escalera, tratada escultóricamente interviene en la transición entre el mencionado vacío y el primer grupo de accesos, mientras que sobre la calle Bolívar, una escalera cilíndrica separa el acceso al hotel de la terraza de la confitería, y a este conjunto del mencionado vacío inicial.

El tratamiento de los bordes interiores, presenta una marcada y buscada "rigidez", estableciéndose una L en donde se sitúan, sobre uno de los lados, una sucesión de locales mientras que sobre el otro: sectores de apoyo, ascensores y escaleras de servicio. Este borde "duro", hace de marco y contención de las formas "blandas" con la que los arquitectos resuelven el acceso al Instituto, la mesa de entradas, la terraza y el ingreso a la confitería. A su vez, este conjunto de paquetes funcionales y sus conexiones, quedan divididos por una rampa que desde la vereda de la calle Bolívar conduce, sin interrupciones, hasta el nivel de la galería comercial. Produciéndose de este modo la sectorización de las llegadas a las distintas partes del programa, que se concretan sin interferencias. Encontrando nuevamente un argumento para su resolución equivalente en ambas calles. Sobre la calle Junín se ubica: la entrada al instituto de Previsión Social, el acceso del personal y de servicio. Por medio de una rampa, el ingreso del sector de comercios.

Desde la calle Bolívar, es posible entrar al nivel de los comercios desde dos puntos, por medio de una escalera o por medio de una rampa. De igual modo al hotel de pasajeros, a la confitería y al servicio del hotel. Estableciéndose un entramado de movimientos, que sin interferencias, conceden dinamismo al nivel de los accesos.Finalmente una sucesión de pilares establece el límite último entre el edificio y la calle, dejando un espacio intersticial entre ella y los contornos redondeados de las carpinterías que configuran los distintos puntos de ingreso, generándose una zona semi-exterior, que en sombra, ofrece un descanso del abrazador sol misionero.

Del estudio del corte surgen también, aspectos para destacar: el edificio se organiza con una estratificación funcional en vertical. Manteniendo el criterio "clásico" de basamento se ubica un primer volumen, de tres niveles, que cocidos por una rampa, distribuyen desde el nivel de la vereda paquetes programáticos; medio nivel hacia abajo, locales comerciales, medio nivel hacia arriba, accesos diferenciados a los diversos sectores y a la galería comercial. El recorrido ascendente de la rampa hacia el tercer nivel de oficinas, obliga a retomar la dirección hacia la vereda, dejando en su descanso un balcón a la calle. Luego de este grupo contenido en el basamento, se despega el volumen del hotel. 
Aunque este criterio, en principio clásico, es reconvertido en clave moderna, así el basamento se constituye como negación del lleno. Un espacio "vaciado" se propone para desarrollar los intercambios de accesos y movimientos. Limitado en uno de sus lados, por una grilla tridimensional de parasoles y pilares y por el otro por la línea de carpinterías, estableciendo un gran lugar intermedio, que en doble altura remeda aquella apreciación que exaltaba al reverso del espacio: la interioridad, como la gran conquista de la arquitectura. ${ }^{128}$

Hacia arriba, el prisma de base rectangular, reúne a los sectores comunes del hotel en las dos primeras plantas (ubicadas inmediatamente después, por sobre los tres niveles de basamento) y luego de ellas, y siempre en sentido ascendente a una doble crujía de habitaciones, conformadas por losas y entrepisos sin vigas, ofrece idéntico tratamiento en ambas caras, para mediar con el exterior (ver memoria de los autores, anexo pág.71 y 72), una veranda conformada por un espacio semi exterior, un antepecho y baranda de hormigón, sugiere una resolución análoga a la utilizada por los mismos autores, en el concurso para el Hospital Escuela de Córdoba.

Estudiar el volumen y emplazamiento del IPS, obliga a entenderlo como un conjunto. Efectivamente el edificio de Soto y Rivarola establece un fuerte vínculo con el correo. El IPS se desarrolla en dos plantas de basamento, que respetan la altura del retranqueo enmarcado por las columnas de doble altura del correo, reformuladas en la nueva construcción, para luego extenderse en el cuerpo principal del edificio, ambos de idéntica altura. Esto es llamativo, ya que el edificio del instituto tiene dos pisos más. Esto se debe a que los autores, forzaron la normativa municipal para poder concentrar la totalidad del programa, sin sobrepasar por ello, la altura del edificio vecino.

Los antepechos de las carpinterías se continúan y las líneas principales del correo, encuentran en el edificio de Soto y Rivarola continuidad. Así, la fachada cortina del correo sirve para trazar líneas en la nueva propuesta, que estructuran un frente que se materializa en una doble envolvente. Una primera malla, conformada por pilares, vigas y parasoles mantienen el ritmo de ventanas y antepechos del vecino edificio, mientras que otro plano de aberturas, ubicado por detrás de aquella, se estructura con un orden propio. Un bloque retranqueado de servicios articula la relación entre ambos edificios, evitando una continuidad material, que a esta altura parecería redundante.

Así los elementos principales, del edificio pre existente encuentran respuestas en la propuesta de Soto y Rivarola, sea por continuidad o por reinterpretación, ambos edificios establecen un diálogo, pudiéndose entender como un conjunto ricamente articulado.

La materialidad merece realizar un análisis pormenorizado. Evidentemente el tratamiento del hormigón, que exhibe la terminación en bruto, no puede ser pasado por alto. Y ubica al edificio en medio del desarrollo y experiencias que por entonces, y de manera simultánea Le Corbusier realizaba en sus últimas obras, o Niemeyer experimentaba en las suyas. Múltiples edificaciones en Latinoamérica, mostraban el mismo lenguaje material y solo basta recorrer algunas obras de Emilio Duhart y el Edificio para Naciones Unidas construido en Santiago de Chile entre 1960 y 1966, obras de Félix Candela en México; el Museo de Arte Moderno de San Pablo, de Lina Bo Bardi en 1958, y la producción de Vilanova Artigas, para interpretar al presente caso como a un integrante más de la encrucijada que tensaba a la disciplina por aquel entonces.

128 FOCILLON, Henri (1934/1943)(2010). La vida de las formas seguida de El elogio de la mano. France. Paris Press es univeritaires.pp.43-44. 
Es posible proponer cierto desarrollo en paralelo con el de otros profesionales, que en el mismo momento se desempeñaban en Latinoamérica, así el caso del arquitecto Fruto Vivas, sus primeras obras como el Hotel Moruco (Estado de Santo Domingo de Barinas 1954), realizadas en madera, utilizando dobles techos y galerías, las experimentaciones llevadas a cabo en la Casa "Playa Grande" (Estado de Vargas 1954) y las realizaciones ejecutadas en Hormigón como el Club Táchira (Caracas 1955) y si bien es cierto que sus indagaciones intentaban reproducir el sistema de los agrupamientos celulares, la construcción de tejidos o la organización de tramas ${ }^{129}$, muchas veces obtenía resultados formales muy próximos a los aquí estudiados. Sin embargo es necesario destacar, que para Soto y Rivarola, el edificio del IPS, continúa el camino de experimentación y búsqueda iniciado en la Escuela en Leandro N. Alem, trasladado a un edificio de diferente base programática, pero que participa del mismo espíritu y exploración material. La aparición de volúmenes de potente expresión plástica (en la escuela la cubierta y la sala de música, aquí escalera y accesos) vinculados a la indagación material, conforman la base temática común en ambos proyectos y la búsqueda e intereses de la oficina. Galerías, halles de gran riqueza espacial, dotados de alturas dobles, balconeo de pasarelas desplazadas y espacios semi cubiertos, cuidada ejecución y estudiada interpretación del lugar y el programa, establecieron el entramado intelectual, con el que Soto y Rivarola construyeron su arquitectura, en la que el Instituto se configuró, quizás, como el punto culminante de su producción y búsqueda.

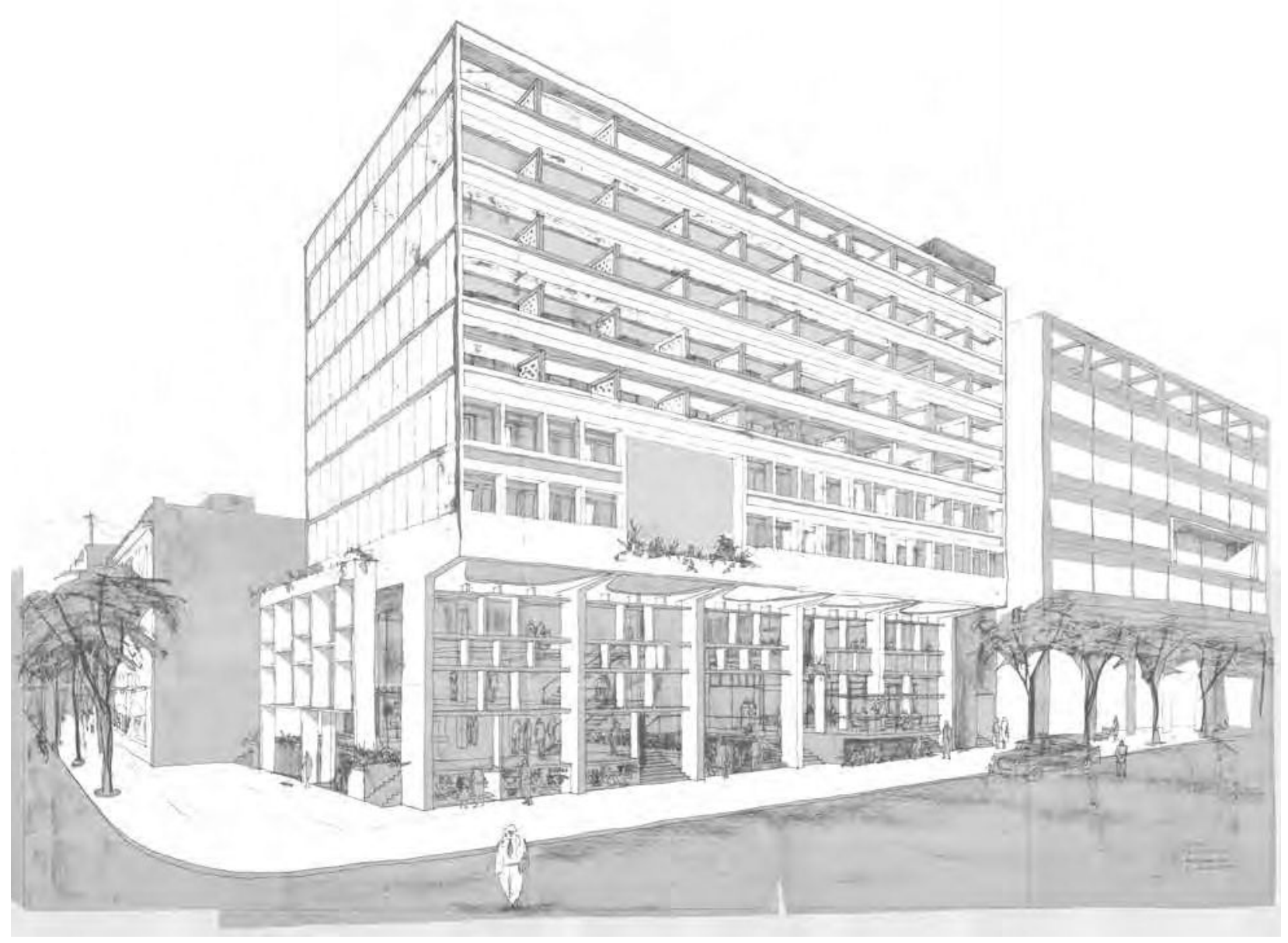

Imagen 74: Perspectiva exterior de conjunto que integraba uno de los paneles oroginales del concurso.

129 ALIATA, Fernando (2013) Estrategias Proyectuales, Los géneros del proyecto moderno: El retorno de la analogía: formalismo y diseño biotécnico. Buenos AiresArgentina. Editorial SCA/Diseño.pp.106-110 

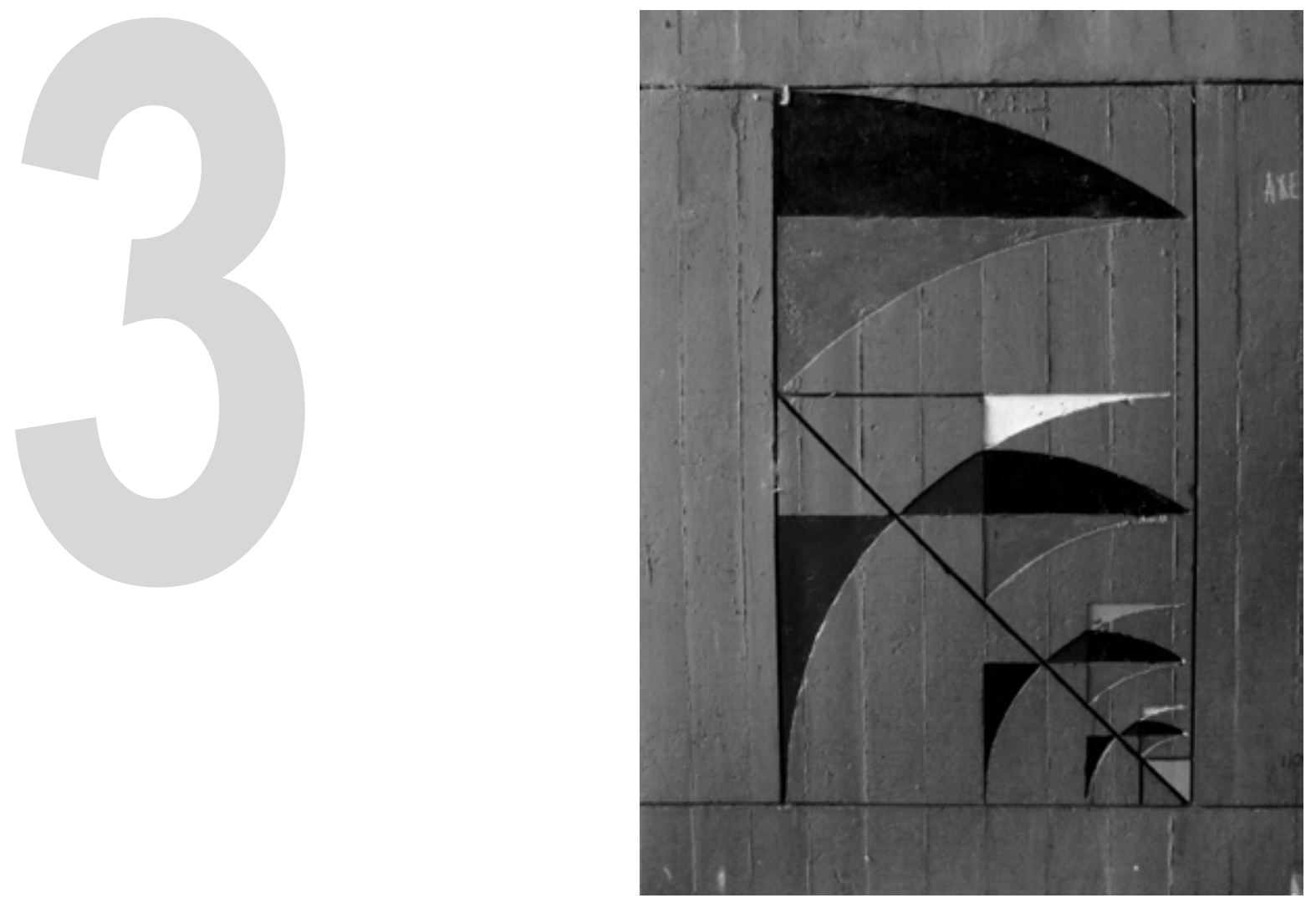

Imagen 75: Bajo relieve ejecutado en uno de los pilares de la Escuela en Alem: Proporciones 


\section{Madera, hormigón; composición y sistema.}

\section{Madera}

Es posible identificar, en la memoria descriptiva que Soto y Rivarola, elaboraron como parte de la documentación del concurso para las cuatro escuelas, la metodología de diseño utilizada, basada en una arquitectura de partido, proveniente de la formación academicista que aún preponderaba en el ámbito de la FAU UBA. Es importante señalar que el primer premio del concurso para las escuelas en Misiones, lo obtuvieron a muy poco de haberse graduado como arquitectos. La presencia de los mecanismos y criterios propios del beaux arts también es señalado por el propio Rivarola: "el tratado de Durand nos sirvió como una eficaz guía en la búsqueda tipológica presente en el proceso proyectual"128 o por Roberto Fernández (2004) quien en el libro sobre Mario Soto, apunta que pertenecían a un grupo de profesionales cuya etapa universitaria no contó con una formación tajantemente moderna, sino todavía oscilante entre buena parte de trabajos de corte academicista. ${ }^{129}$

Sin embargo, las características ponderadas por el jurado en el fallo, al hacer mención de la unidad "aula", reconocida como argumento de proyecto y como módulo vital de la grilla generadora del conjunto, parecen descubrir otro mecanismo de generación. Es notable la lectura que surge de separar el análisis del proyecto, tomando por un lado los aspectos discursivos y por otro las piezas gráficas que completan la documentación.

El estudio del proyecto en sí mismo corrobora la crítica del jurado, aun cuando los autores no han hecho explícito en la memoria, ninguno de los aspectos señalados. El análisis de la planta de conjunto permite encontrar el módulo "aula” en articulación con el uso galerías semicubiertas, brindadas a la circulación que une partes programáticas claramente individualizadas, dentro de un conjunto de precisa geometría.Este planteo arquitectónico pudo ser motivado, por la particular condición del concurso, que proponía para las escuelas una localización dentro de la provincia de Misiones, pero sin asignar un lote específico. Por tanto, la propuesta, debía permitir un alto grado de flexibilidad para adaptarse a las condiciones particulares que el sitio definitivo le impondría al proyecto. Así, el planteo realizado por Soto y Rivarola, participa de las premisas de flexibilidad y crecimiento.

Los autores pusieron en práctica un mecanismo que se vuelve a verificar en sus obras posteriores y que radica en establecer primeramente, el argumento del proyecto sobre una base determinada (en este caso en particular, por el clima y el programa) y otra indeterminada (la ausencia al momento de tener que realizar el proyecto, de una localización precisa que estableciera relaciones fijas con el entorno). Por tanto el resultado debía oscilar entre ambos extremos, buscando una síntesis, que permaneciendo en equilibrio, atendiera a los problemas planteados.

128 Entrevista realizada por el autor a Rodolfo Rivarola el 8 de julio de 2014

129 FERNÁNDEZ, Roberto (2004) En MAESTREPIERI, Eduardo (2004): España y Argentina en la arquitectura del siglo XX Mario Soto (p14) Buenos Aires. Argentina. Sociedad Central de Arquitectos. p.14. 
La indeterminación del punto de partida era contrarrestada con un planteo de clara expresión geométrica y programática, utilizando argumentos que cuanto más los alejan del repertorio académico, más los acercan a una arquitectura que comenzará a tomar forma y mayor desarrollo durante los años 1960 y 1970, pudiéndose pensar a estas obras, como a un interesante antecedente.. Efectivamente, el análisis del proyecto, y de la crítica del jurado encuentran claras resonancias con aspectos que Aliata (1993) encuadra dentro de la categoría de arquitectura de sistemas en el libro: Materiales para la Historia ${ }^{130}(\ldots)$, tales como serialidad, indeterminación formal, ausencia de límites, posibilidad de ampliación infinita, al mismo tiempo que el método de descomponer las partes del programa, dejando abiertas nuevas posibilidades, parecen tener exactas coincidencias con los argumentos y problemáticas enumeradas por Soto y Rivarola en las memorias de sus proyectos.

El planteo desarrolla un lenguaje formalmente reconocible, por la división morfológica de sus partes funcionales, la apelación a imágenes tecnológicas de carácter dinámico, fueron reemplazadas por otras surgidas de la ejecución en madera. La resolución de la técnica constructiva propuesta por los arquitectos, reformuló la tradicional utilización del material, brindando un resultado novedoso, combinando en un solo procedimiento profesionalismo y experimentalismo. ${ }^{131}$ Efectivamente se puede considerar como un punto de inflexión en el que triunfa una suerte de "poética" de la simplificación de la noción académica de partido, que implicaba la construcción de los proyectos como ideas fuerza.

Esta arquitectura se mueve dentro de una generalizada noción de crisis de los parámetros tradicionales y puede leerse en sus propuestas una búsqueda por caracterizar lingüística y proporcionalmente cada una de las partes que conforman el sistema. Sobre todo en un primer momento cuando la tendencia de organización espacial parece concentrarse en la posibilidad de identificación de estructuras tipológicas legibles en sí mismas de acuerdo a su función e interconectadas por un sistema de circulación, cuyo cometido es coser a cada uno de estos subconjuntos. Así aparece la noción de un sistema de puntos fijos estructurales y circulaciones que interconectan a cada uno de los paquetes funcionales y cuya sumatoria de como resultado, un edificio que se hace claro en cuanto a su uso, a partir de la identificación precisa de las partes programáticas que contiene.Esta idea inicial constituye una verdadera gramática de partes ensamblables. ${ }^{132}$

Así, situar al proyecto de las escuelas, en la zona de transición entre los métodos académicos y la arquitectura de sistemas, permite explicar las indeterminaciones propias de los períodos de cambios. En donde los diversos elementos se combinan conformando un nuevo repertorio arquitectónico. Esta experiencia será el punto inicial de sucesivos desarrollos que tendrán en un próximo proyecto la posibilidad de ponerse a prueba y refinarse. Efectivamente, será el proyecto para las Hosterías, en el que esta metodología alcanzará un mayor grado de expresividad.

Las hosterías concluyen el grupo de obras que la oficina ejecutó en madera en la provincia de Misiones, cerrando una primera etapa en donde los proyectos realizados por Soto y Rivarola buscaban lograr una identificación morfológica de estructuras funcionales, vinculadas por el sistema circulatorio.

130 ALIATA, Fernando (1993). "Voz: Arquitectura de Sistemas". En: Materiales para la Historia de la Arquitectura el Hábitat y la Ciudad en la Argentina. La Plata. Universidad Nacional de La Plata.pp.160-131.

131 ALIATA, Fernando (1993)."Voz:Arquitectura de Sistemas"...cit.

132ALIATA, Fernando (1993). "Voz: Arquitectura de Sistemas"...cit. 
Todo este conjunto se organizaba según un criterio de jerarquías, evidenciado por la ubicación, tamaño y resolución de cada parte programática, conectada mediante los sistemas de movimiento que materializaban los ejes de la composición.

La decisión de experimentar con el uso del material, proponiendo el sistema estructural como un rasgo característico del lenguaje desarrollado por la oficina, llevó a ubicar primeramente, a la madera en el centro de la escena. Ya que de manera simultánea atendía problemas de la más variada escala, resolvía las dificultades tecnológicas que imponía el sitio, permitía un sencillo transporte, acopio y montaje, mediante la utilización de un material autóctono, pero al mismo tiempo abría una puerta de conexión a lo nacional. Soto y Rivarola realizaron una interpretación del trabajo en madera, trazando un vehículo hacia un nuevo lenguaje formal. ${ }^{133}$ De esta manera función y forma condensan su experiencia a partir de la organización programática y constructiva, dando como resultado un espacio donde quedan integradas. Demostrando una clara búsqueda por expresar los aspectos materiales entendidos como parte del proceso de organización, formalización práctica y constructiva. Así planteado, el sistema de sostén de los proyectos elaborados por la oficina, respondían al imperativo moral, sostenido desde la larga tradición racional a partir de Viollet le Duc.

Con la finalización del proyecto para las hosterías se clausura, no solo la utilización de la madera como elemento configurador de la estructura y del lenguaje, sino también una manera de proyectar, hasta aquí llevada adelante por la oficina. La organización de los edificios y sus partes componentes, era guiada por un camino de experimentación en donde se verificaba la exploración geométrica a partir del desarrollo de grillas rigurosas, correctas y calculadas, dispuestas a partir de ejes y simetrías. Las composiciones así logradas, se iniciaban a partir del estudio del proyecto en planta tal como sugería el primer Le Corbusier, fusionado con la idea de partido y la voluntad de carácter que la construcción debía poder exhibir. Este recorrido inicial, fue alimentado con densidad teórica y pericia constructiva, experimentando un claro pasaje, que partiendo del pensamiento bidimensional desarrolló en los arquitectos, la capacidad de lograr la manipulación de volúmenes complejos. Esta voluntad puede considerarse coincidente con la necesidad por desarrollar la conformación del espacio mediante formas duraderas. Los edificios que se inician, luego de esta etapa, condensan todas estas preocupaciones, un pensamiento volumétrico, generado a partir de las secciones y formas tridimensionales es materializado mediante la utilización, ya no de la madera como el elemento primordial de la composición, sino el hormigón.
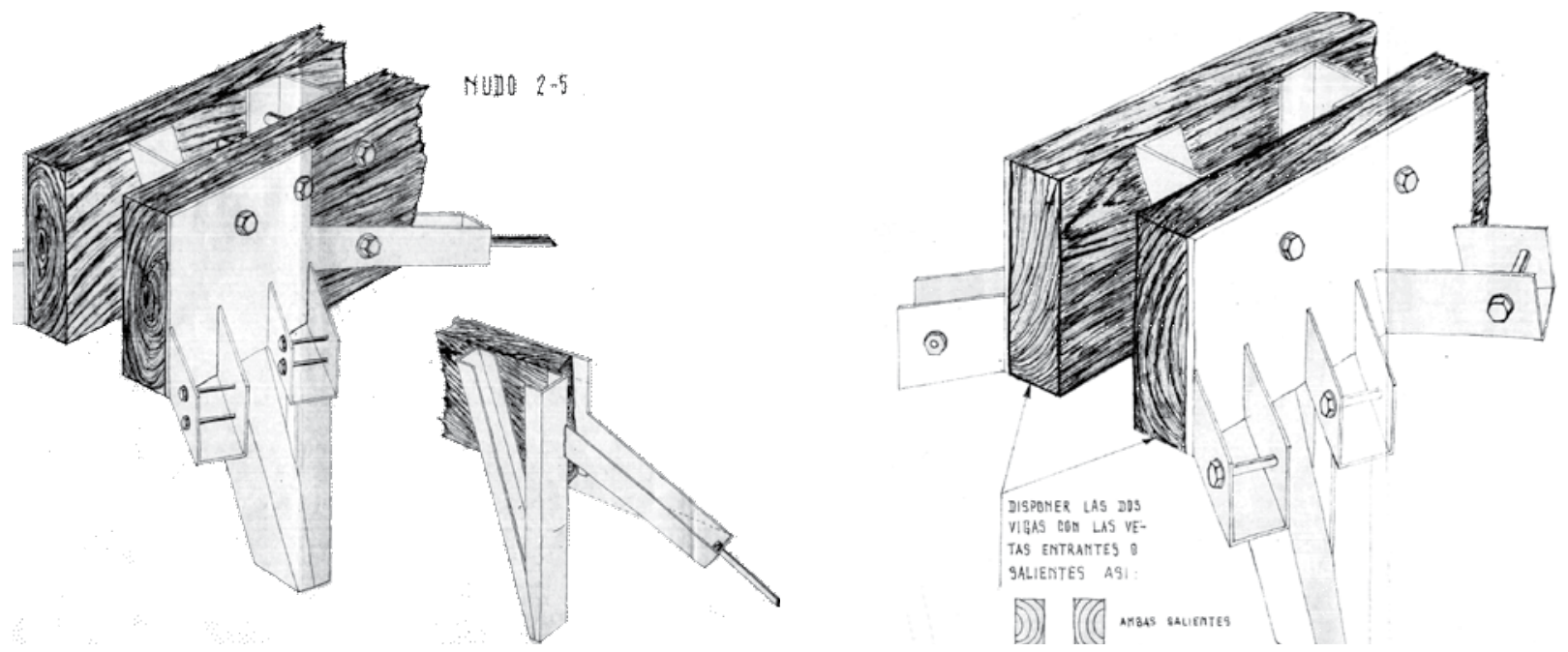

Imágenes 76, 77: Detalles de encastres de maderas y su ubicación en el corte general.

133 Bastaría con realizar un relevamiento de los edificios realizados por los sindicatos en los balnearios y colonias de verano en posiciones rivereñas para corroborar una suerte de derivación tipológica de aquellas construcciones de Misiones. Ver edificio balneario del MOP. R. Cappelli. 1968. Nota del Autor. 


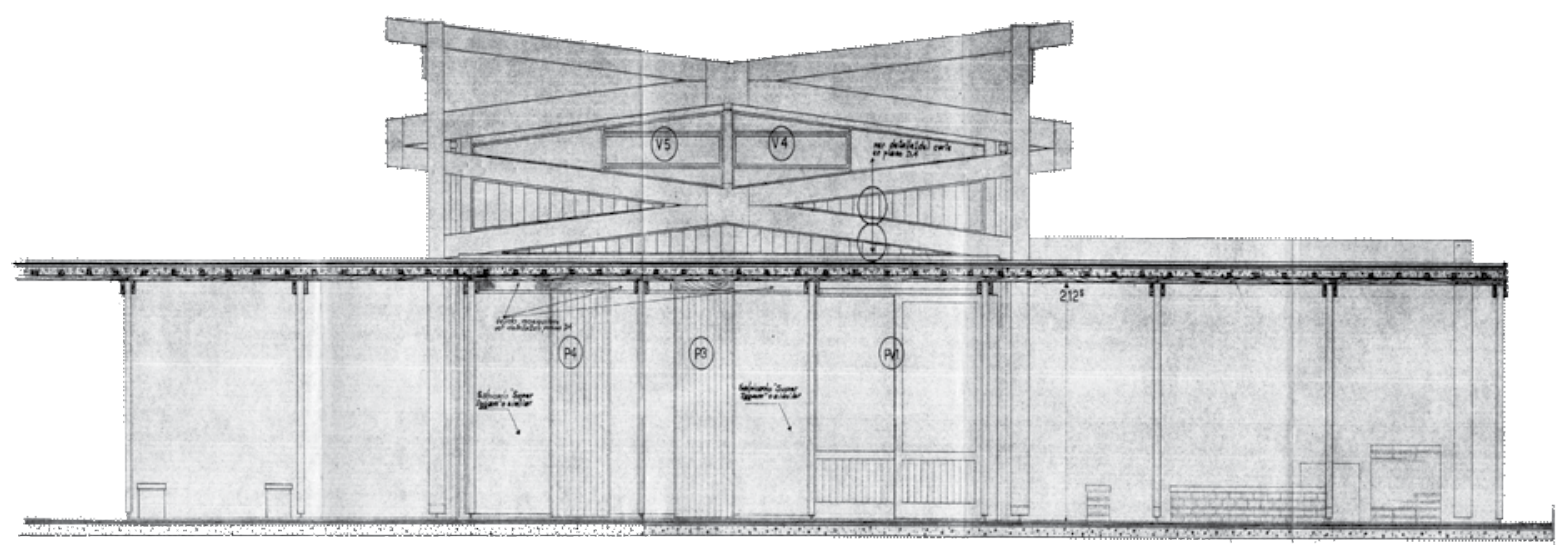

yistza A
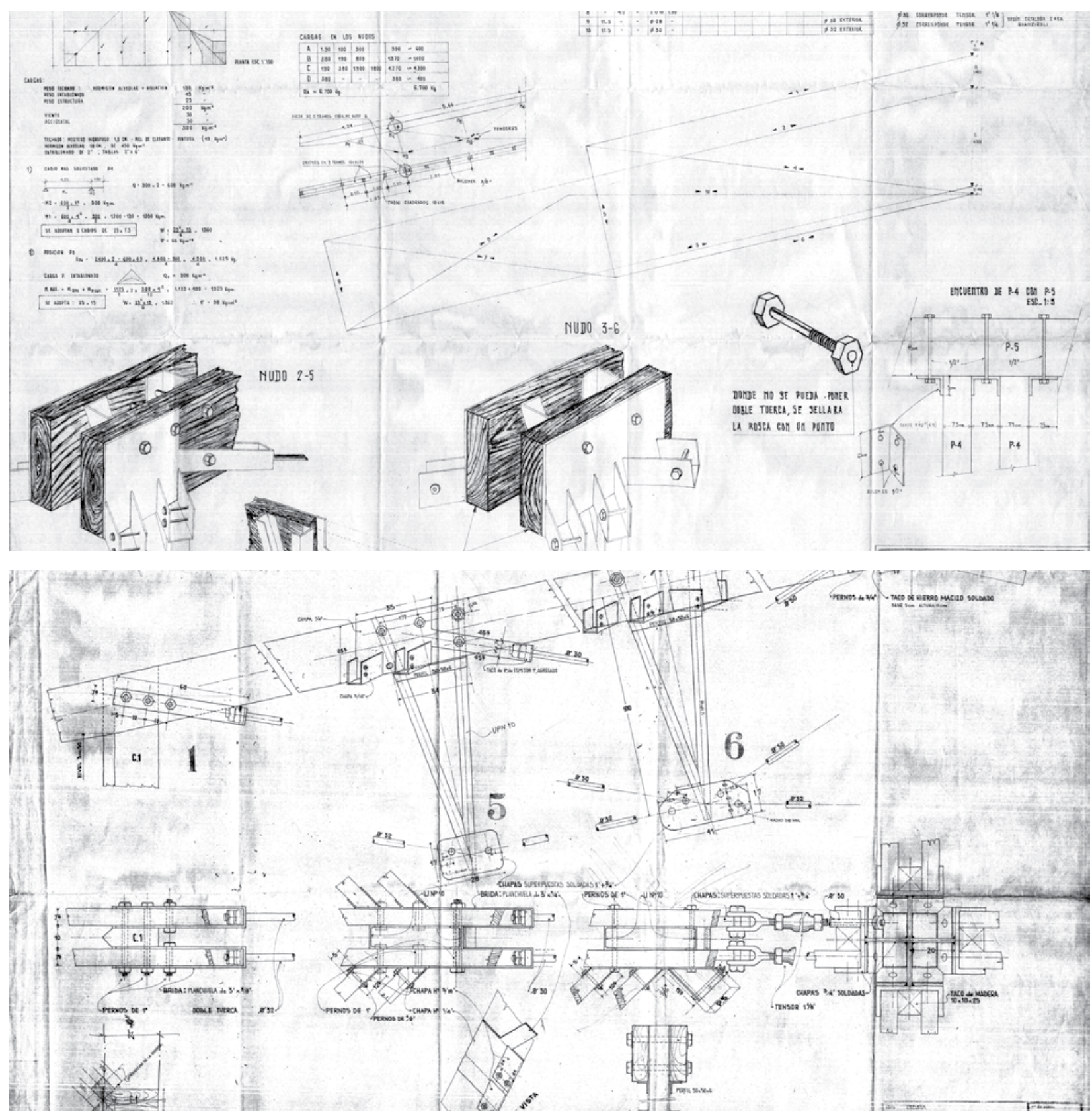

Imágenes 78; 79; 80: Corte, con ubicación de encuentros; Láminas de detalle de encastres 


\section{Hormigón}

En 1948, Le Corbusier proyectó "la Sainte Baume" en Bouche de Rhone, Francia y la primera propuesta para el Centro de Peregrinación "la Cité permanente", en donde se encuentra en el diseño de las células el punto de partida de desarrollos posteriores: el proyecto para el hotel Roq et Rob, de 1948; la casa Sarabhai en India en 1954 y la casa Jaoul en Neuilly, en París en 1956 y al mismo tiempo retomaba conceptos desarrollados en la casa para fin de semana construida en Boulougne Sur Seine, en Paris en 1935.

James Stirling, junto a James Gowan construyeron Ham Common en Londres en 1958; Bresciani, Valdes, Castillo y Huidobro, en Santiago de Chile, en 1961 realizaron el proyecto del edificio Quinta Normal. Atelier 5: la casa Adler, en Suiza en 1958 y en 1960 una Fábrica en la ciudad de Thun, también en Suiza.

Louis Kahn proyectó y construyó el Museo de Arte de la ciudad de New Haven que se inauguró en 1953. De manera simultánea se redescubre y reivindica la arquitectura de las casas populares realizadas en la cuenca del Mediterráneo, de las que Le Corbusier había realizado dibujos y croquis recopilados luego en el libro Mi obra (1960); Alison y Peter Smithson analizaron y ponderaron las casas baratas de Marruecos en África, continente que también fue visitado por Aldo van Eyck entre 1947 y 1961.

Pero sin lugar a dudas, la Unidad de habitación de Marsella, realizada entre 1947 y 1952, produjo un fuerte impacto en las generaciones de arquitectos contemporáneos. Sea por adhesión u oposición, la obra no pasó desapercibida y fue entendida como un hecho arquitectónico indiscutible. ${ }^{134}$ Para Banham, la innovación fundamental del edificio, no radicaba en los audaces módulos utilizados, ni la originalidad en la distribución, ni en las pretensiones sociológicas, sino en el abandono por parte de Le Corbusier, del concepto de ficción previo a la guerra, de considerar al hormigón armado como el material preciso de la era de la máquina. Aquí surgió y fue utilizado como un material nuevo, explotando sus rudezas y las de los encofrados de madera, consiguiendo una superficie arquitectónica de áspera grandiosidad. La tosquedad de su aspecto, la relación entre las proporciones, la huella del encofrado, produjo uno de los edificios más importantes de Le Corbusier en el que se logró la más absoluta concordancia retórica entre la tecnología moderna y la arquitectura antigua expuesta en "Vers una Architecture"135

El modo en que el hormigón fue utilizado en la India, en Chandigarh (1951-1955), en Ronchamp (19501955) o en el Convento de la Tourette (1957) por Le Corbusier, se convirtió en un material expresivo, capaz de poner de manifiesto, al mismo tiempo, lo más característico de sí mismo y configurar el recinto y lo arquitectónico. Es estructura y molde, contenedor y vacío, forma y espacio. Adquiere coordenadas ideológicas y éticas, el material se expone tal cual es, las superficies no son recubiertas ni pulidas, un cierto arcaísmo y primitivismo que aún sin tener un fuerte arraigo en las costumbres constructivas de un lugar, trasunta en algo nacional. Así lo interpretaron Soto y Rivarola. La selva de Misiones, parece ser el escenario ideal para su implementación, y el rotundo cambio de concepción arquitectónico-tecnológico, es motivado por la indagación en las nuevas prácticas constructivas iniciadas por el estudio.

La irrupción del material, dentro del repertorio formal de la oficina se da coincidentemente con el cambio de escala de los edificios que proyectaron sobre el final de la década de 1950. Se lo utilizó con el mismo criterio que el dispuesto en el uso de la madera: la experimentación, una extrema rigurosidad en la planificación, en el diseño, en los detalles y en su implementación. La técnica constructiva se constituyó como eje central de la ideación arquitectónica. La forma resultante del edificio es la consecuencia de la elección del material. Cada pieza, sector y detalle conforma un todo armónico y fue utilizado por los arquitectos, para exhibir la misma claridad, tanto en el desarrollo del conjunto como en el de las partes.

134 BANHAM, Reyner (1967). El Brutalismo en Arquitectura. ¿Ética o estética? Barcelona Ed. Gustavo Gili Barcelona. pp.16-22. 135 Banham. R (1967). El Brutalismo en Arquitectura...cit. 
El cambio e incorporación del hormigón, es simultáneo a la preminencia del corte en la concepción espacial de los edificios que lo utilizan. Un paulatino alejamiento de la organización originada a partir de la planta, se verifica, mientras que la madera desaparece como elemento estructural fundamental. Las plantas se compactan y simplifican, al mismo tiempo que el corte y la espacialidad interior se enriquece. La organización pierde el lenguaje de pabellón, de piezas ensambladas, organizadas a partir de ejes, simetrías y circulaciones, la singularidad que busca expresar las funciones contenidas a partir de un sistema de jerarquías e individualidades, puestas de manifiesto en los proyectos de las escuelas y hosterías, deja paso a la concepción total, en donde ya las piezas no se identifican como singulares, sino que convocan a la concepción de un espacio total.

Múltiples referencias evocan las preocupaciones del momento y es posible encontrar reverberaciones de elementos desarrollados por Le Corbusier en distintos sectores de las obras de Soto y Rivarola, proyectadas o ejecutadas en hormigón: los balcones exteriores de Marsella (1947/1952) tienen una clara reformulación en las expansiones de las habitaciones del hospital escuela de Córdoba, concurso que fue ganado por Soto y Rivarola, junto a Eithel Traine y Manuel Borthagaray. El sistema de parasoles y rejillas de los brise-soleil desarrollados por Le Corbusier en Marsella, en el convento de la Tourette (1957/1960), o en la fábrica de Saint Dié (1948/1951), fue recreado en las fachadas del Instituto de Previsión Social de Posadas, aunque con una mayor justificación bioclimática que aquellos. La escalera exterior de la Unidad, cumple un rol igualmente escultórico a la realizada en el IPS de Posadas. Así el empleo del material realizado por la oficina, oscila entre el desarrollo de partes funcionales y piezas escultóricas, pudiendo explotar todo el potencial, que recorre desde lo utilitario a la expresión formal.

El caso de la Escuela Normal $\mathrm{N}^{\circ} 1$ en Leandro N. Alem, es curioso, en el sentido de que podría entenderse como una búsqueda sugerida. Tal como suele ocurrir en los procesos de ideación colectiva, es muy difícil individualizar a los autores de las resoluciones particulares, a los que motivan determinados cambios o a los que reaccionan de una manera, particularmente creativa a ellos. Efectivamente, la utilización del hormigón como material para la resolución de la cubierta, fue propuesto por las autoridades provinciales, que pretendían la duración y el carácter representativo, que tal material garantizaba. Tal variación motivó la transformación total del proyecto elaborado para el edificio. La incorporación del hormigón armado, fue entendida como la posibilidad de realizar nuevas experimentaciones, tanto formales como espaciales. El cambio de material propuesto se limitaba solo a sugerir su utilización, el resultado que motivó, fue producto de la reconversión total del proyecto, realizada por Soto y Rivarola y de la indagación en un lenguaje y método de proyecto hasta ese momento inexplorado por la oficina, solo algunas experiencias realizadas en Tucumán por Soto, cuando trabajaba para el Ministerio de Salud de la Nación, en compañía de Eithel Traine en el plan Carrillo, pueden trazar un precedente. Por lo demás, y hasta ese momento, las obras realizadas eran resueltas mediante la combinación de madera con ladrillo y piedra, teniendo la utilización de listones, vigas y cabreadas, como los temas centrales del repertorio material y estructural.

A partir de Alem, el hormigón, adquirió para la oficina, gran preponderancia, se utilizó aunando criterios de uso con otros evidentemente plásticos y simbólicos. El carácter escultórico de las piezas moldeadas a partir de su empleo así lo manifiesta y les permitió desarrollar y refinar su capacidad expresiva. De igual modo, la utilización del hormigón, supuso la incorporación de una nueva mecánica para poder llevar a cabo la obra. Sobre todo si se tienen en cuenta las zonas donde los edificios se implantaron, la absoluta ausencia de caminos adecuados y mano de obra experimentada que pudiese llevar adelante los trabajos necesarios. Por tanto, los arquitectos, pronto se vieron en la necesidad de brindar clases de geometría descriptiva a los capataces para poder garantizar la correcta ejecución de los planos que entregaban y elaborar minuciosos dibujos, muchos de ellos a mano alzada, para facilitar la interpretación de los detalles constructivos. 
La combinación de los distintos actores que intervinieron, Alfredo Yantorno, Carlos Laprovítola y el capataz Acosta, recordado por Rivarola, ${ }^{136}$ entre muchos otros, permitieron llevar adelante una obra de enorme complejidad, en un entorno difícil y con medios, siempre escasos.
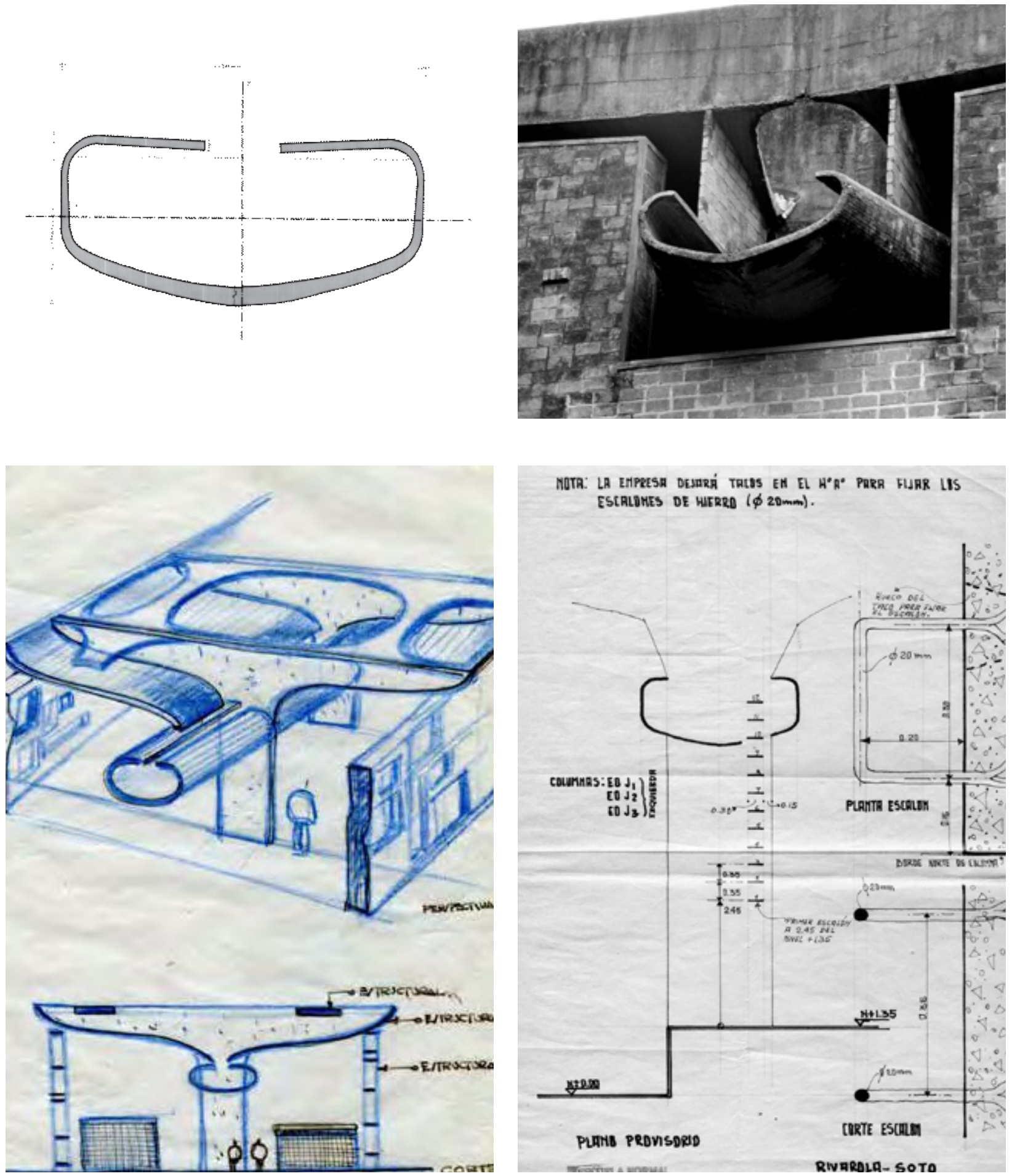

Imágenes 81; 82; 83 y 84: Detalle del rebalse de la canaleta central; Foto de la canaleta central; Dibujo de la cubierta con esquema de corte; Corte detalle de armado de encofrado de la canaleta central. Toda la documentación corresponde a la escuela en Alem

136 Rivarola R, en el transcurso de la presente investigación, recuerda haber llegado al obrador de la Escuela en Leandro N. Além, y haberse encontrado al capataz, leyendo un libro de geometría descriptiva para descifrar la manera en que los encofrados debían realizarse. Cabe destacar, que por pedido expreso de los Arquitectos Soto y Rivarola, el mismo capataz fue seleccionado para supervisar y organizar los trabajos que se realizarían, posteriormente en el IPS, de Posadas. Entrevista realizada por el autor. (Mayo de 2014) 


\section{Composición, sistema}

La Facultad de Arquitectura de la Universidad de Buenos Aires, invitó a los franceses Gastón Bardet, arquitecto formado en La Escuela Nacional de Bellas Artes de Paris y en el Instituto Urbano de Paris en 1936; al arquitecto Jacques Lambert premiado en 1928 por proyectos de planificación urbana, y André Misenard ingeniero y colaborador de Le Corbusier en temas de acondicionamiento climático, autor de los libros: "L'homme et le climat" (1937) y "A la Recherche de l'Homme" (1954); durante el ciclo lectivo de 1948 y a los italianos: Pier Luigi Nervi ${ }^{137}$, arquitecto e ingeniero formado en la Universidad Nacional de Bolonia, Italia quien dictó varias conferencias, luego compiladas y publicadas en un libro bajo el título de: Nervi Pier Luigi (1951), "El lenguaje arquitectónico" Buenos Aires 1951. Y a Bruno Zevi, Doctor en arquitectura de Harvard, profesor y estudioso de la obra de Frank Lloyd Wright, profesor de Historia de la Arquitectura en la IUAV de Venecia, en la facultad de Arquitectura de la Universidad de Roma, entre otras, contratado como profesor extraordinario, para dictar un curso sobre Historia de la Arquitectura Moderna, y realizar distintos seminarios en 1951. Al mismo tiempo, el plantel docente de la Facultad estaba conformado por los arquitectos Alfredo Casares, Mauricio Repossini, Alfredo Agostini, que se desempeñaron como profesores adjuntos a partir de 1949 y Alberto Prebisch y Eduardo Catalano que se sumarían dos años después, todos ellos fervientes promotores y practicantes de la arquitectura moderna.

Este conjunto de arquitectos, teóricos y docentes pone de manifiesto la diversidad de miradas que sobre la arquitectura tenían los distintos actores y explica, tal vez el particular momento que atravesaba la disciplina. Como señala Aliata, la crisis de la modernidad, recortada contra el resurgimiento de un nuevo clasicismo, que le reclamaba a la arquitectura de vanguardia una "nueva monumentalidad" por la ausencia de signos representativos. La arquitectura moderna, se presentaba ante la mirada ortodoxa, insolvente para establecer un campo de referencias con la adecuada carga simbólica que a su criterio, los nuevos programas requerían. Esta ausencia de signos representativos era, para muchos, la causa de un nuevo clasicismo surgido como reflujo de la tradición académica de 1930 aparecido para compensar la insolvencia de la nueva disciplina ${ }^{138}$.

Construir y componer, eran ideas centrales que encerraban una postura teórica dentro del campo disciplinar. Alejandro Bustillo, claro exponente de estos preceptos, sintetizaba en su obra la mirada de toda una generación, que encontraba en Durand, y su principal noción de convenance, la manera de conseguir la adecuación de un edificio a su destino conforme su utilidad ${ }^{139}$. Los principios fundamentales impartidos en la Escuela de Arquitectura: el carácter arquitectónico y la aplicación del set clásico subsistía en la FAU UBA, pero se fusiona con esquemas de distribución que prescindían de transiciones, antecámaras y pochés. La idea de partido representaba para algunos aquél carácter que se espera y exige de la arquitectura, para otros la predeterminación de conceptos de síntesis y la clara materialización de programas complejos y su notoria expresión formal. En ambos casos constituye un marco de referencia, un mecanismo de control de la "composición". Ejes, geometría, formas puras, simetrías y equilibrio, conforman una matriz heredada del academicismo que se resiste a desparecer definitivamente del campo disciplinar y de la enseñanza de la arquitectura. El empleo de la geometría, como herramienta de generación del proyecto opera con autoridad, como un reconocimiento calculado de la forma para el uso, no solo la razón ejercita una exclusividad soberana sino que ofrece un sistema neutral de orden.

137 Pier Luigi Nervi fue autor, entre muchas otras obras del: Stadio Artemio Franchi de Florencia (1931); la Sede de la Unesco en Paris en colaboración con Marcel Breuer (1950), la Torre Pirelli en Milán (1950) y el Palazetto dello Sport en Roma (1957)

138 ALIATA, Fernando (2013). Estrategias Proyectuales Los Géneros del proyecto moderno. Lógicas proyectuales; Partido y Sistema en la evolución de la arquitectura contemporánea en la Argentina.Buenos Aires. Sociedad Central de Arquitectos. pp.45-68.

139 SHMIDT, Claudia (2007). "Alejandro Bustillo: un modernista contrariado" En: LEVISMAN Martha (2007) Alejandro Bustillo. Un proyecto de arquitectura nacional, Archivos de Arquitectura Contemporánea, Buenos Aires, Arca. pp.447-470. 
Siendo el partido la expresión de la síntesis buscada en la ideación del edificio que el carácter debería convalidar. Este es, posiblemente, uno de los motivos de la supervivencia de la idea de partido en la práctica y enseñanza de la arquitectura.

Conceptos como partido, carácter, composición, conforman las bases del método clásico codificados por la didáctica académica. Surge así un momento en que nuevos procederes de proyecto se solapan con las antiguas prácticas. La búsqueda de una arquitectura de base científica, durante la década de 1950, de una metodología para el diseño y la "teoría de sistemas" se entremezcla con préstamos y referencias de los viejos procederes. Generando una manera de proyectar que caracterizará buena parte de la producción arquitectónica de las décadas de 1950 hasta $1970^{140}$. Según afirmaba Banham, lo que buscaba esta generación era una justificación histórica para sus propias posturas y las buscaban en dos áreas principales de la historia, la tradición de la propia arquitectura moderna y en las más lejanas tradiciones del clasicismo. ${ }^{141}$

\section{Epílogo:}

"La forma cúbica de mi casa de vidrio y la separación de unidades funcionales en dos formas absolutas en lugar de una agregación principal o secundaria de partes, tienen su origen en Ledoux, el padre dieciochesco de la arquitectura moderna. El cubo y la esfera, las formas matemáticas puras, eran muy queridas por aquellos revolucionarios del barroco y nosotros somos sus descendientes..."142

De este modo Philip Johnson, describía y justificaba la genealogía de su casa de New Canaan, edificada en Conecticut e inaugurada en 1949. Con su mirada, simplificaba la situación de una generación de jóvenes arquitectos que poseían un enorme grado de sofisticación en el estudio y manejo de la historia de la arquitectura. Las ideas de Colin Rowe, expresadas en artículos como "Las matemáticas de la vivienda ideal" (1947); o en su tesis The theoretical drawings of Inigo Jones"143 (1948), realizada bajo la tutela de Rudolf Wittkower, Manierismo y arquitectura moderna (1950) tensaban el debate disciplinar y aportaba suficientes argumentos para desarrollar una mirada renovada a determinados valores clásicos, considerados permanentes. Tenía una visión opuesta a la de Banham y su interpretación de la modernidad buscaba precedentes formales en la historia.

Wittkower había publicado en 1945 Pseudo Palladian elements in English neoclassicism ${ }^{144}$, en donde la cuestión de la transmisión y transformación eran presentadas como un campo legítimo, tanto para el estudio como la interpretación de la arquitectura. Pero fue con su libro "Los fundamentos de la arquitectura en la edad del humanismo" publicado en 1949, en el que expuso un cuerpo de teoría de la arquitectura donde función y forma aparecían significativamente conectadas por las leyes objetivas que gobiernan el cosmos, tal como Alberti y Palladio las entendían, promoviendo un enorme impacto en toda una generación de estudiantes de arquitectura.

140 ALIATA, Fernando (2013). Estrategias proyectuales...cit.

141 BANHAM, Reyner (1955), The new brutalism, En Architectural Review...cit. pp.354-361.

142 JOHNSON, Philip (1950). "House at the New Canaan," Conecticut. Architectural Review 108 № 645 septiembre de 1950 p.153.

143 ROWE, Collin (1947) "The Theoretical drawings of Inigo Jones, Their source and scope”. (tesis de maestría en Historia del Arte University of London, Noviembre de 1947)

144 WITTKOWER, Rudolf (1949) "Principles of Palladio's architectura". En: Architectural principles in the age of humanism. London. Warburg Institute. Para una discusión completa del método analítico de Wittkower en el contexto del toería del arte moderno ver PAYNE Alina (1994) "Rudolf Wittkower and Architectural Principles in the age of modernism" En: Journal of the Society of Architectural Historians. $\mathrm{N}^{\circ} 53$. Sepiembre. pp 322-342.. 
La arquitectura en la edad del humanismo ${ }^{145}$, fue una enorme contribución a la historia de la arquitectura y quedó alineada en importancia a la obra de Bruno Taut Modern Architecture, (1929); a la versión traducida al inglés de La arquitectura del humanismo de Geoffrey Scott (1932); la de Nikolaus Pevsner: Pioneros del movimiento moderno (1936), o a la de, Sigfried Gideon Espacio tiempo y arquitectura (1941).

Es de este modo en que se puede establecer una zona de transición, parafraseando a Banham, una "zona de silencio", en donde gran cantidad de estudiantes de arquitectura atravesaron su período de formación jalonado entre una mirada oscilante que descubría una modernidad incipiente y un academicismo debilitado.

Estas transformaciones, pueden verificarse, no solo en los arquitectos en etapa de formación, sino en otros en pleno ejercicio de la profesión como Le Corbusier por ejemplo, que en sus primeros escritos realizaba un llamado a resignificar la planta, como la generadora del espacio, dejando traslucir aspectos de la tradición clásica en su disciplina intelectual abstracta dedicada a la buena proporción, la simetría, la claridad y el racionalismo.

Esa aproximación bidimensional a la arquitectura y a sus modos de organización parece tener cierta deuda intelectual con los tratados de Durand, mencionados por el propio Rivarola. Pero si se efectúa una aproximación a Durand, desde la perspectiva que expone Tafuri en el artículo "eclipse del objeto", se resignifica toda su operación, y se presenta al "Tratado" como a un sistema completamente anti-simbólico que ignora deliberadamente la historia en favor de una lógica combinatoria y compositiva, basada en la geometría, produciendo una absoluta ruptura del canon clásico en favor de lo "moderno".

Esta tesis no busca trazar una renovada (o no tanto) construcción del criterio de "influencia" ni aportar una simplificada regla de evolución lineal, de los procesos de ideación que confluyen y se ponen en juego durante la elaboración del proyecto de arquitectura. Sino manifestar y descubrir el denso campo intelectual en donde cada época establece la relación entre formas y sistemas. Para poder entender las razones que llevan (a un arquitecto) según Theodor Adorno a ese extraño imperativo doble: la libertad de autoimponerse leyes ${ }^{146}$. Utilizando como medio de constatación a la crítica para poder dedicarse al presente con todo el peso de la experiencia del pasado ${ }^{147}$.

Hacia 1955, Banham era muy consciente de que se había dejado de lado toda posible referencia al "palladianismo" en la arquitectura británica. Peter Smithson había introducido un debate dentro de la Architectural Association en el que instaba a no hablar más de proporción, ni de simetría, algo que Banham describió como la declaración de guerra al academicismo.

El escenario de la segunda posguerra, introdujo necesidades concretas en las sociedades que habían quedado devastadas y la arquitectura se propuso como una herramienta válida para la reconstrucción. Esta premisa le confirió la exigencia de regular sus procesos optimizando plazos y modos de ejecución. El gusto por las proporciones, el auge de sistemas de medida como el "modulor" durante la década de 1950, manifiestan la preocupación disciplinar de contar con herramientas y métodos que permitiesen, por la vía de la prefabricación, desarrollar un sistema de pronta respuesta a necesidades que se presentaban acuciantes.

145 WITTKOWER, Rudolf (1947) Architectural principles in the age of humanism...it. El texto estaba formado por artículos previamente publicados en Journal of the Warburg and Courtauld Institute "Alberti's approach to antiquity in architectur 1940-1941". pp. 1-18. Como ha observado Alina Payne, para la publicación del libro Wittkower, añadió el capítulo primero: "La iglesia de planta central en el Renacimiento" y un apartado sobre aspectos ópticos y psicológicos de Palladio, véase Alina Payne (1944) Rudolf Wittkower and architectural principles...cit.

146 ADORNO, Theodor W (2001). Kant's critique of pure reason. Stanford University Press. Stanford 2001. pp. 54-55.

147 VIDLER, Anthony (2008). Histories of the inmediate present. Inventing architectural modernism...cit. 
Serialidad, repetición, indeterminación, crecimiento indefinido, fueron los nuevos temas que aparecieron en la disciplina, motivados tanto por condiciones impuestas por las transformaciones operadas en el campo cultural, científico y tecnológico, como por la necesidad que la realidad planteaba. El modo de respuesta que la arquitectura ensayó, recorrió el camino de la individualización programática, los nuevos complejos se generaron por una composición de elementos diferenciados, que fueron vinculados a partir de las circulaciones que oficiaban como conectores de las diversas partes, pero sin desaparecer completamente el sentido de orden y jerarquía. Richard Llewelyn Davies ${ }^{148}$ y Gherhard Kallman, concebían en un artículo publicado en un número especial de la Architectural Review, una arquitectura sin fin, indeterminada, en la cual unidades agregables podrían añadirse o suprimirse sin alterar la calidad estética. Este sistema propuesto por Davies, tenía una clara implementación dentro de la arquitectura sanitaria y escolar y era el correlato de investigaciones centradas en fuertes desarrollos tecnológicos. Estos estudios fueron compilados en los cuadernillos de la Post War Building Studies, Heating and Ventilation of Schools, by the heating and ventilation (reconstruction) comitee, of the building research board of the department of scientific \& industrial research. London 1947, Published for the Ministry of Works by the Majesty's stationery office sixpence net. Y los Building Boletin de 1955 a 1957. Estudiados por Rivarola durante la elaboración de los proyectos para las escuelas de Misiones ${ }^{149}$.

De este modo las ideas de flexibilidad, crecimiento e indeterminación fueron incorporadas a una realidad que motivada por distintas razones, también las demandaba, encontrando esta arquitectura de partes ensamblables y circulaciones estructurantes un inmejorable campo de aplicación, al amparo de la arquitectura de Estado. Las experiencias desarrolladas por Soto y Rivarola se dan de manera coincidente con las realizaciones llevadas a cabo por el Ministerio de Educación británico, que puso en práctica la utilización del sistema "CLASP" (Consortium of Local Authorities Special Project) en $1957^{150}$, que perseguía, al igual que los ejemplos aquí destacados, la idea de prefabricación liviana, montaje en seco, proyectado a partir de una grilla modular flexible y adaptable. Las recomendaciones de la UNESCO, a partir del Congreso celebrado en Ginebra durante el mismo año, aunque de manera posterior al proyecto de las escuelas en Misiones, establecen la profunda coincidencia de objetivos, pero al mismo tiempo, el error de considerarlas como una consecuencia directa de aquellas. Sería más adecuado ubicar la experiencia de Soto y Rivarola de manera contemporánea y simultánea, al desarrollo experimentado en materia de arquitectura escolar en Gran Bretaña y Estados Unidos, aunque tal vez motivado por las mismas fuentes, que se identifican en 1947.

Así confluyó en una sola operatoria, la posibilidad de realizar una serie de obras que resolvieran las demandas de una nación en expansión, que reclamaba construcciones para resolver necesidades concretas pero al mismo tiempo atendiera valores simbólicos, en una gesta plena de desafíos. Soto y Rivarola transitaron esos rumbos, realizando una arquitectura de nítida determinación de conceptos e ideologías, donde la elección y uso del material reclama una renovada lectura de su producción.

La realidad política, la revolución cubana, los ideales sociales, cruzaron la práctica de la oficina, motivando redefiniciones y obligando cambios de rumbo. El encuentro de Soto con el Che Guevara durante el VII Congreso de la Unión Internacional de Arquitectos realizado en la Habana en 1963 ${ }^{151}$; el viaje en el barco

148 Richard Llewelyn-Davies: 24 de diciembre de 1912/27 de octubre de 1981; arquitecto británico, profesor de arquitectura en la Bartlett University de Londres y profesor de la Escuela de Estudios Ambientales.

149 Se realizarían múltiples recopilaciones de estos artículos, luego publicados por ejemplo en la serie Architecture after 1960, en Architectural Review, en la que se reunieron escritos de Reyner Banham, Architectural Review $127 \mathrm{~N}^{\circ} 755$ enero de 1960; Reyner Banham, "Stocktaking" Architectural Review 127 N 75 febrero de 1960; R. Llewelyn Davies "The Science side and weapons systems, computers and human sciences" Architectural Review 127 N757 marzo de 1960 pp.188-190.

150 SHMIDT, Claudia (2013). "El impacto de las ideas de posguerra en las transformaciones del aula escolar. El caso argentino 19571967". En: RDA Revista de Arquitectura: Teoría/Enseñanza/Producción. Año 2 №2, PP.22-27.

151 Para una profundización de las circunstancias que rodearon al congreso consultar: DORFMAN, César (2014)Havana 63. Editorial 
soviético Nadezhda Krúpskaya que partió desde Río de Janeiro, junto a Vilanova Artigas, Wladimiro Acosta, Fabio Moura Penteado, Carlos Almeida ${ }^{152}$ entre otros, para asistir al congreso y eludir el boicot motivado por Estados Unidos, permitiría evocar a aquel memorable realizado en el Patris II en 1933, motivó en Soto la reafirmación de convicciones que hasta allí no se habían manifestado en su total dimensión; un lento, pero inexorable distanciamiento conduciría a Soto y a Rivarola por caminos diferentes, haciendo que la tan exitosa sociedad comenzara a trabajar en forma espaciada, hasta interrumpir definitivamente su actividad.

No obstante, aún la oficina tuvo la ocasión de desarrollar los proyectos para la Terminal de Ómnibus de Resistencia en el Chaco en 1964 y del Hospital Escuela de Córdoba en 1968, concursos en los que obtuvieron sendos primeros premios, dando cabal muestra de su talento y clara interpretación del profundo sentido de su arquitectura. Es de este modo que se pretende estudiar a estos arquitectos, realizando la exégesis de su verdadera modernidad, no a partir del modo en que revisaron el pasado, hundiendo más o menos allí sus raíces, sino por la forma en que descifraron al presente. Es entonces, donde su mirada moderna produjo una arquitectura anclando permanencias, puntos de referencia, que se convirtieron en los hitos inamovibles que nos permiten hoy, escribir esta historia.

Movimiento Brasil

152 CARRANZA Y MARTÍN (1963-1969) Arquitectura y Política. Las izquierdas argentinas en los Congresos de la UIA (La Habana, Cuba, 1963 y BuenosAires, Argentina, 1969). En XIV Jornadas Interescuelas/ Departamentos de Historia. Departamento de Historiade la Facultad de Filosofía y Letras. Universidad Nacional de Cuyo, Mendoza, 2013. p.7. 


\section{Créditos de imágenes y fotografías.}

Imagen 1; pag. 5 Myriam Goluboff, archivo personal de Mario Soto

Imagen 2; pag. 5 Myriam Goluboff, archivo personal de Mario Soto

Imagen 3; pag. 6 Centro Gubernamental de la Pampa, archivo digitalizado del libro: C. Testa Obras comple tas Imagen 4; pag. 6 Centro Gubernamental de la Pampa, archivo digitalizado del libro: C. Testa Obras completas Imagen 5; pag. 8 Maqueta de Escuela: Archivo R. Rivarola Imagen 6; pag. 8 Fotografía Desagüe escuela en Leandro N Alem: Archivo R. Rivarola

Imagen 7; pag. 9 Fotografía Interior comedor escuela: Archivo R. Rivarola

Imagen 8; pag. 9 Fotografía maqueta escuela: Archivo R. Rivarola

Imagen 9; pag. 9 Escuela en Alem. Fotografía cedida por Luis Müller

Imagen 10; pag. 9 IPS. Archivo R. Rivarola

Imagen 11; pag. 10 Terminal de Micros de Chaco. Archivo: R. Rivarola

Imagen 12; pag. 12 Mapa de las colonias jesuíticas: fuente:Museo Jesuítico

Imagen 13; pag. 17 Portada del Proyecto de Ley:

Imagen 14; pag. 17 Mapa Argetnina : Arthur Von Seelstrang. A Tourmente del depto ingienieros de la Nación 1875

Imagen 15; pag. 17 Fotografía propia de un diario de la época.

Imagen 16; pag. 17 Fotografía de los festejos de la provincialización. Diario El Territorio

Imagen 17; pag. 23 Mapa confeccionado por el autor

Imagen 18; pag. 23 Mapa de Misiones: Fuente: Unam Conicet

Imagen 19; pag. 23 Mapa de Misiones: Fuente: Diario El territorio 6 de febrero de 1978.

Imagen 20; pag. 31 Planos digitalizados por el autor, del Plan URBIS.

Imagen 21; pag. 31 Planos digitalizados por el autor, del Plan URBIS.

Imagen 22; pag. 31 Planos digitalizados por el autor, del Plan URBIS.

Imagen 23; pag. 31 Planos digitalizados por el autor, del Plan URBIS.

Imagen 24; pag. 32 Planos digitalizados por el autor, del Plan URBIS.

Imagen 25; pag. 32 Planos digitalizados por el autor, del Plan URBIS.

Imagen 26; pag. 32 Planos digitalizados por el autor, del Plan URBIS.

Imagen 27; pag. 32 Planos digitalizados por el autor, del Plan URBIS.

Imagen 28; pag. 34 IPS. Archivo R. Rivarola

Imagen 29; pag. 37 Escuelas en Misiones. Archivo: R. Rivarola digitalizados por el autor Imagen 30; pag. 37 Escuelas en Misiones. Archivo: R. Rivarola digitalizados por el autor Imagen 31; pag. 37 Escuelas en Misiones. Archivo: R. Rivarola digitalizados por el autor Imagen 32; pag. 37 Escuelas en Misiones. Archivo: R. Rivarola digitalizados por el autor Imagen 33; pag. 37 Escuelas en Misiones. Archivo: R. Rivarola digitalizados por el autor Imagen 34; pag. 37 Escuelas en Misiones. Archivo: R. Rivarola digitalizados por el autor Imagen 35; pag. 40 Planta escuela en Misiones. Archivo R. Rivarola digitalizados por el autor Imagen 36; pag. 41 Corte de la escuela, Panel del concurso. Archivo: R. Rivarola, digitalizados por el autor Imagen 37; pag. 42 Planos de detalles: Archivo R. Rivarola, digitalizados por el autor Imagen 38; pag. 42 Planos de detalles: Archivo R. Rivarola, digitalizados por el autor Imagen 39; pag. 42 Planos de detalles: Archivo R. Rivarola, digitalizados por el autor Imagen 40; pag. 43 Fotografías de la escuela: Archivo R. Rivarola, digitalizadas por el autor Imagen 41; pag. 43 Fotografías de la escuela: Archivo R. Rivarola, digitalizadas por el autor Imagen 42; pag. 44 Planta Hosterías: Archivo: R. Rivarola, escaneadas por el autor Imagen 43; pag. 44 Planta Hosterías: Archivo: R. Rivarola, escaneadas por el autor Imagen 44; pag. 44 Planta Hosterías: Archivo: R. Rivarola, escaneadas por el autor Imagen 45; pag. 44 Planta Hosterías: Archivo: R. Rivarola, escaneadas por el autor Imagen 46; pag. 44 Planta Hosterías: Archivo: R. Rivarola, escaneadas por el autor Imagen 47; pag. 44 Planta Hosterías: Archivo: R. Rivarola, escaneadas por el autor Imagen 48; pag. 45 Dibujo conceptual efectuado por R. Rivarola y digitalizado por el autor Imagen 49; pag. 45 Fotografía de Misiones. Archivo Mario Soto/Myriam Goluboff Imagen 50; pag. 47 Panel de cortes y vistas del concurso para las Hosterías. Archivo: R. Rivarola Imagen 51; pag. 47 Perspectiva del concurso de las hosterías: Autor: Jorge de la Vega: Archivo R. Rivarola Imagen 52; pag. 48 Fotografías de las Hosterías: Archivo R. Rivarola Imagen 53; pag. 49 Fotografías de las Hosterías: Archivo R. Rivarola Imagen 54; pag. 49 Fotografía de la escuela en Alem. Archivo Mario Soto/Myriam Goluboff Imagen 55; pag. 50 Fotografía interior de la escuela en Alem. Archivo R. Rivarola Imagen 56; pag. 50 Fotografía interior de la escuela en Alem. Archivo R. Rivarola Imagen 57; pag. 50 Fotografía interior escuela en Alem. Archivo R. Rivarola 
Imagen 58; pag. 53 Corte de la escuela en Alem, Archivo R. Rivarola, digitalizada por el autor Imagen 59; pag. 53 Fotografía de la escuela en Alem. Archivo Mario Soto/Myriam Goluboff Imagen 60; pag. 53 Corte de la escuela en Alem, Archivo R. Rivarola, digitalizada por el autor Imagen 61; pag. 53 Dibujo de la sala de música. Archivo: R. Rivarola, digitalizado por el autor Imagen 62; pag. 54 Dibujo de la sala de música. Archivo: R. Rivarola, digitalizado por el autor Imagen 63; pag. 55 Dibujo de la sala de música. Archivo: R. Rivarola, digitalizado por el autor Imagen 64; pag. 55 Dibujo de la sala de música. Archivo: R. Rivarola, digitalizado por el autor Imagen 65; pag. 55 Fotografía interior de la escuela en Alem. Archivo R. Rivarola Imagen 66; pag. 57 Planta baja escuela en Alem. Archivo R. Rivarola Imagen 67; pag. 58 Fotografía de la escuela en Alem. Archivo Mario Soto/Myriam Goluboff Imagen 68; pag. 58 Fotografía de la escuela en Alem. Archivo Mario Soto/Myriam Goluboff Imagen 69; pag. 59 Detalle de la composición del cerramiento carpintería sala de música de la escuela en Alem Imagen 70; pag. 59 Detalle constructivo de la cubierta de Hormigón de la escuela en Alem Imagen 71; pag. 60 Fotografía del IPS. Archivo R. Rivarola, digitalizadas por el autor Imagen 72; pag. 60 Fotografía del IPS. Archivo R. Rivarola, digitalizadas por el autor Imagen 73; pag. 60 Fotografía del IPS. Archivo R. Rivarola, digitalizadas por el autor Imagen 74; pag. 63 Perspectiva original del concurso del IPS: Archivo: R. Rivarola, digitalizados por el autor Imagen 75; pag. 64 Fotografía del bajo relieve de la escuela en Alem. Autor: Luis Müller Imagen 76; pag. 67 Planos detalles de encuentros de maderas: Archivo: R. Rivarola, digitalizados por el autor Imagen 77; pag. 67 Planos detalles de encuentros de maderas: Archivo: R. Rivarola, digitalizados por el autor Imagen 78; pag. 68 Planos detalles de encuentros de maderas: Archivo: R. Rivarola, digitalizados por el autor Imagen 79; pag. 68 Planos detalles de encuentros de maderas: Archivo: R. Rivarola, digitalizados por el autor Imagen 80; pag. 68 Planos detalles de encuentros de maderas: Archivo: R. Rivarola, digitalizados por el autor Imagen 81; pag. 71 Detalle constructivo gárgola y canaleta. Archivo R. Rivarola y digitalizado por el autor Imagen 82; pag. 71 Fotografía escuela en Alem: Luis Müller Imagen 83; pag. 71 Dibujo conceptual efectuado por R. Rivarola y digitalizado por el autor Imagen 84; pag. 71 Corte constructivo. Archivo: R. Rivarola y digitalizado por el autor 


\section{ARCHIVOS, BIBLIOTECAS Y RESERVORIOS CONSULTADOS}

Archivo Francisco Bullrich. Universidad Torcuato Di Tella

Archivo General de la Nación

Archivo General de la Provincia de Misiones

Archivo Mario Soto / Myriam Goluboff

Archivo Municipal de la Ciudad de Posadas

Archivo Raúl Rivarola

CEDIAP-MECON. Centro de Información e Investigación en Arquitectura Pública. Ministerio de Economía de la Nación

Argentina

Facultad de Arquitectura, Diseño y Urbanismo, Universidad de Buenos Aires

Facultad de Arquitectura y Urbanismo, Universidad Nacional de La Plata

Secretaría de Investigación y Posgrado, Universidad Nacional de Misiones

Sociedad Central de Arquitectos

\section{BIBLIOGRAFÍA}

ABINZANO. Roberto Carlos (1985). Procesos de Integración en una sociedad multiétnica.

Tesis Doctoral, Tomo I. Capítulo VI. Universidad de Sevilla España

ADORNO, Theodor W. (2001). Kant's critique of pure reason. Stanford University Press. Stanford

ALIATA, Fernando (1993). "Voz: Arquitectura de Sistemas": Materiales para la Historia de la

Arquitectura el Hábitat y la Ciudad en la Argentina. La Plata. Universidad Nacional de La Plata

ALIATA. Fernando (1999). "Comentario". En: ALTAMIRANO, Carlos (ed.). La Argentina

en el siglo XX. Buenos Aires. Ariel

ALIATA, Fernando (2013). Estrategias Proyectuales, Los géneros del proyecto moderno:

El retorno de la analogía: formalismo y diseño biotécnico. Buenos Aires. SCA/Diseño

ALTAMIRANO, Carlos (2002). Sociologías de la cultura. Buenos Aires. Paidós.

Archivo de la Gobernación de Misiones. Copiador A desde 27/09/1934 hasta 10/06/1936 folio 337

BALLENT, Anahí (1995). El diálogo de las antípodas: los Ciam y América Latina.

Buenos Aires, FADU UBA.

BALLENT, Anahí, GORELIK, Adrián (2001) "País urbano o país rural: la modernización territorial y su crisis". En Cattaruzza, A (comp.), Nueva Historia Argentina Tomo 7. Buenos Aires. Sudamericana

BANHAM, Reyner (1967). El Brutalismo en Arquitectura. ¿Ética o estética?. Barcelona. Gustavo Gili

BANHAM, Reyner (1969). The Architecture of the well-tempered environment. Londres. The Architectural Press

BANHAM, Reyner (1978). Megaestructuras. Futuro urbano del pasado reciente. Barcelona. Gustavo Gili

BUCHRUCKER, Cristian (1987). Nacionalismo y Peronismo. La Argentina en la

Crisis ideológica mundial (1927-1955). Buenos Aires. Sudamericana

BULLRICH, Francisco. (1969). Arquitectura latinoamericana 1930/1970. Buenos Aires. Sudamericana.

BULLRICH, Francisco (1963). Arquitectura Argentina Contemporánea. Buenos Aires. Nueva Visión

CÁMARA ARGENTINA DE LA CONSTRUCCIÓN (1952). “2do Plan Quinquenal”.

Revista Construcciones, Año 8 No. 91

CARRANZA Y MARTÍN (1963_1969) Arquitectura y política. Las izquierdas argentinas en los Congresos de la UIA. La Habana-BuenosAires. Cit. en: XIV Jornadas Interescuelas/ Departamentos de Historia. Departamento de Historiade la Facultad de Filosofía y Letras. Universidad Nacional de Cuyo, Mendoza, 2013

CHOAY, Françoise (1970). El urbanismo. Utopías y realidades. Barcelona. Lumen

PROVINCIA DE MISIONES. CASA DE GOBIERNO (1954). Diario de Sesiones de la Convención

Constituyente de Misiones. Año 1954; 8 de Noviembre/21 de noviembre.

FERNÁNDEZ, Roberto (2004). En MAESTREPIERI, Eduardo (2004). España y Argentina

en la arquitectura del siglo XX. Mario Soto. Buenos Aires. Sociedad Central de Arquitectos

FOCILLON, Henri. (1934/1943) (2010). La vida de las formas seguida de El elogio de la mano.

Paris Presses Univeritaires

GALLERO, María Cecilia; KRAUTSTOFL, Elena (2009). "Proceso de poblamiento y migraciones en la Provincia de Misiones, Argentina (1881- 1970)”. En: Revista de Antropología AVÁ. No 16

GALVAN DUQUE, Hector (1963) Cartilla de autoconstrucción para escuelas rurales. México. Conescal, GOBIERNO DE LA PROVINCIA DE MISIONES, MINISTERIO DE ECONOMÍA Y OBRAS

PÚBLICAS (1956) Concurso de Anteproyectos de edificios incluídos en el Plan de Trabajos Públicos

GOLDHAGEN, Sarah, Anxious Modernism, Montreal, Canadian Centre for Architecture ; MIT, 2000

GORELIK, Adrián (2010). Correspondencias, arquitectura, ciudad y cultura, Buenos Aires, Nobuko

GORELIK, Adrián (2013). Miradas sobre Buenos Aires: Historia cultural y crítica urbana.

Buenos Aires. Siglo Veintiuno 
GORELIK, Adrián (2001/2002). "Antonio Vilar, Peregrinazione del moderno Antonio Vilar e la rete di stazioni di servicio in Argentina 1938-1946". En: Casabella . No 695-696 GREMENTIERI, Fabio; SHMIDT, Claudia (2010). Arquitectura, educación y patrimonio: Argentina 1600-1975. Buenos Aires. Pamplatina HALPERÍN DONGHI, Tulio (1986). Historia contemporánea de América Latina. Madrid. Alianza HALPERÍN DONGHI, Tulio, et alt. (1985). Historia económica de América Latina desde la Independencia a nuestros días, Barcelona, Crítica HOBSBAWN, Eric (2008). "La era de las catástrofes". En HOBSBAWM, E. Historia del siglo XX.

Buenos Aires. Crítica

IRIBARNE, Jorge (Diciembre de 1990). "Las hosterías en Misiones de los arquitectos Soto y Rivarola, hoy".

En: Revista Sociedad Central de Arquitectos, No149

JOHNSON, Philip 1950). "House at the New Canaan, Conecticut".

Architectural Review. No 645 septiembre de 1950

LE GOFF, Jacques. NORA, Pierre (1974) Hacer la historia. Paris.Gallimard

LIERNUR, Jorge Francisco (2001). Arquitectura en la Argentina del siglo XX.

La construcción de la modernidad. Buenos Aires, Fondo Nacional de las Artes.

LIERNUR, Jorge Francisco (2008). "Construcciones industriales y arquitectura a fin de siglo:

entre el envoltorio y el mito". En: Trazas de futuro. Santa Fe, UNL

LIERNUR, Jorge Francisco (2010) Arquitectura en teoría. Escritos 1986-2010. Buenos Aires. Nobuko

LIERNUR, Jorge Francisco y ALIATA, Fernando (Comp.) (2004). Diccionario de Arquitectura

en la Argentina. Buenos Aires, Clarín

LIERNUR, Jorge Francisco, PSCHEPIURCA, Pablo (2008).

"El grupo Austral: acciones e ideas para la construcción de una vanguardia". En: La red Austral, Obras y proyectos de Le Corbusier y sus discípulos en la Argentina 1924/1965. Quilmes. Prometeo

LONGONI, Ana; MESTMAN Mariano (2000). Del Di Tella a "Tucumán Arde"

Vanguardia artística y política en el "68 argentino" Buenos Aires. El Cielo por asalto.

MILLÁN, María del Rosario (2009). "Región Provincia, Capital. Identidades Locales y

Discurso Urbanístico" En: Revista Estudios. Digital , No 22

MINISTERIO DE ECONOMÍA Y OBRAS PÚBLICAS DE LA PROVINCIA DE MISIONES (1956).

Antecedentes Plan Estratégico. Diagnóstico y Situación Actual. Misiones

MONTEYS, Xavier (2010) La gran máquina. La ciudad de Le Corbusier. Barcelona. Gustavo Gili

MUMFORD, Lewis (1969). Perspectivas Urbanas. Buenos Aires. Emecé

OLMO, Carlo; CHIORINO, Cristiana (a cura di) (2010), L'Architettura come sfida. Milano.

Silvana Editoriale PAINE, Alyna (1994). Rudolf Wittkower and architectural principles in the age of modernism".

En: Journal of the Society of Architectural Historians. No. 53

PEDRANZINI, Maximiliano (2010). "Apuntes sobre la Provincialización de Misiones".

En: ROMERO, Luis Alberto (dir.) Historia Política.com. p5. Recuperado 15/07/2014

PIZZETI, Giulio (1 de enero de 1951) "Los nuevos mundos de la arquitectura estructural" Nueva Visión N¹

QUARANTA de ERRECABORDE, Ana María (1987) Historia de la Provincialización de Misiones.

Posadas. Ediciones Montoya

PRESIDENCIA DE LA NACIÓN. SUBSECRETARÍA DE INFORMACIONES (1952). Qué es un Plan Quinquenal.

Buenos Aires.

RAFFAELE, Ana Clara (2012). La construcción de políticas durante el proceso de provincialización

del Territorio Nacional de Chubut: 1954-1955 [en línea]. Trabajo final de grado.

RODRIGUEZ, Fermín (2010) Un desierto para la nación. Le escritura del vacío.

Buenos Aires. Eterna Cadencia

ROMERO, Luis Alberto (2012). Breve Historia Contemporánea de la Argentina 1916/2010.

Buenos Aires. Fondo de Cultura Económica

ROSSI, Aldo (1978) Para una arquitectura de tendencia, Escritos 1956-1972. Barcelona. Gustavo Gili

ROWE, Colin (1981) Ciudad Collage. Barcelona. Gustavo Gili

RUFFINI, Martha (2005). "Algunas reflexiones en torno a la provincialización".

Revista Avances del Cesor, Año V, N5

RUFFINI. Martha (2005). "Peronismo, territorios nacionales y ciudadanía política.

Algunas reflexiones en torno a la provincialización”. En: Revista Avances del CESOR , año V No 5. Rosario

SCHVORER, Esther Lucía (2008). "Misiones: Estructura Social Agraria, estado y

conflictos sociales. Las circunstancias de una historiografía regional". En: ROMERO,

Luis Alberto (dir.) Historia Política.com: http://historiapolitica.com/biblioteca/. Recuperado 12/06/2014.

SENKEVICH, Anatole (1982). "Moisei Ginzburg and the emergence of a

Constructivist Theory of Architecture”. En: GINZBURG, Moisei. Style and epoc. Cambridge M.A, MIT. 
SHMIDT, Claudia (2007). "Alejandro Bustillo: un modernista contrariado".

En: LEVISMAN, Martha (2007). Alejandro Bustillo. Un proyecto de arquitectura nacional.

Archivos de Arquitectura Contemporánea, Buenos Aires, Arca

SHMIDT, Claudia (2012): Palacios sin reyes; Arquitectura pública para la "capital permanente", Buenos Aires 1880-

1890, Rosario, Prohistoria

SHMIDT, Claudia (2013). "El impacto de las ideas de posguerra en las transformaciones del aula escolar.

El caso argentino 1957-1967”. En: RDA. Revista de Arquitectura: Teoría/Enseñanza/Producción, Año 2 N

SHMIDT, Claudia (2013). "Excepción y Circunstancia: Francisco Bullrich y la arquitectura del todo o las partes

El proyecto de la Embajada argentina en Brasilia (1970)". En: 2das Jornadas de Historia y Cultura de

La Arquitectura y la Ciudad; La teoría de sistemas en la transformación de la cultura urbana. Arquitectura,

Ciudad y territorio entre el profesionalismo y la tecno-utopía (1950-1980). Buenos Aires. UTDT-UNL

Summa No 8. Octubre 1963

TAFURI, Manfredo (1980) La esfera y el laberinto. Vanguardia y Arquitectura. De Piranesi

a los años setenta. España. Gustavo Gili

TORRE, Claudia (2010) Literatura en tránsito. La narrativa expedicionaria de la Conquista del Desierto.

Buenos Aires. Prometeo.

Notas al pie: Apa Citation Style.

Cantidad de palabras aproximadas: 34.575 


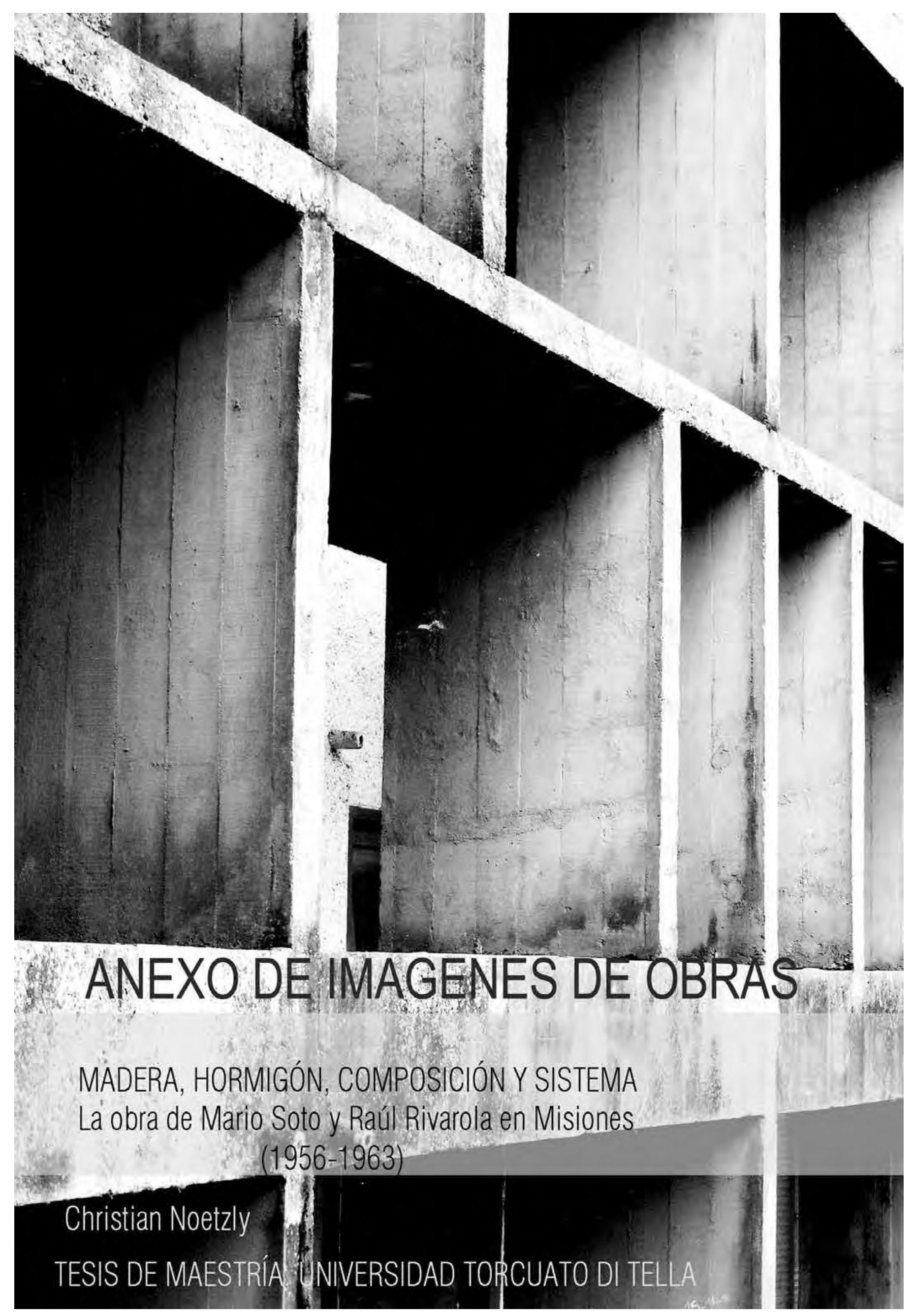





\section{ÍNDICE DE OBRAS}

PU Plan URBIS para Posadas y Misiones

\section{en1}


PLAN REGULADOR PARA LA CIUDAD DE POSADAS Y PLAN ESTRATÉGICO PARA LA PROVINCIA DE

MISIONES

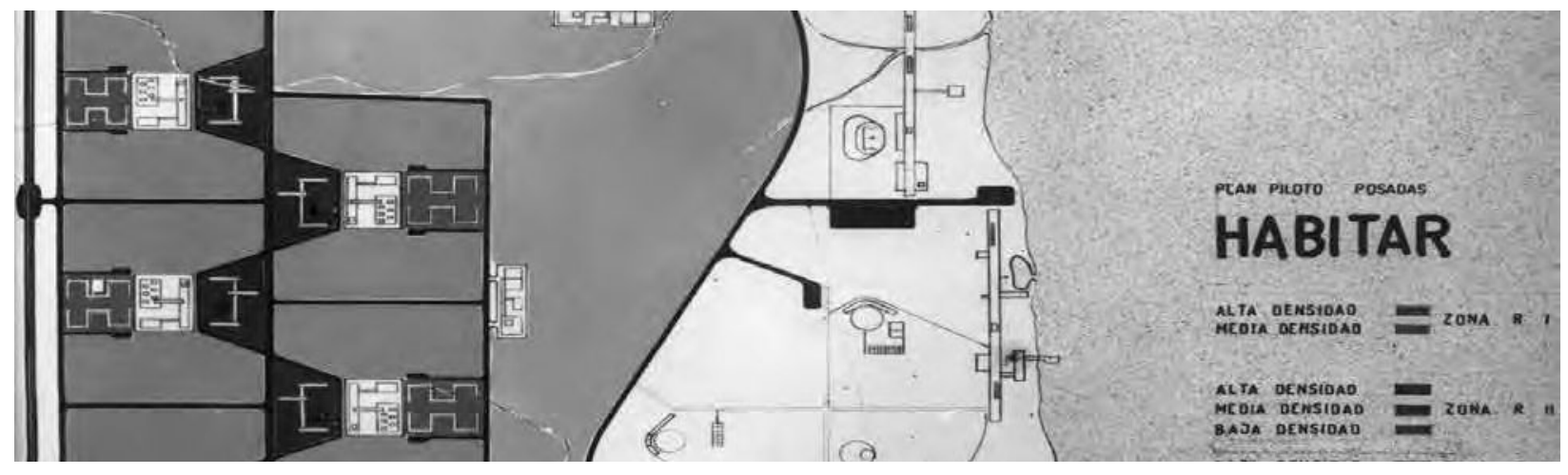




\section{Plan Regulador de la Ciudad de Posadas}

BI LLTOYER.

in atuen os ras:

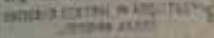

\section{URBIS}

Ministerio de Economia y Obras Poblices de la Provincia de Misiones

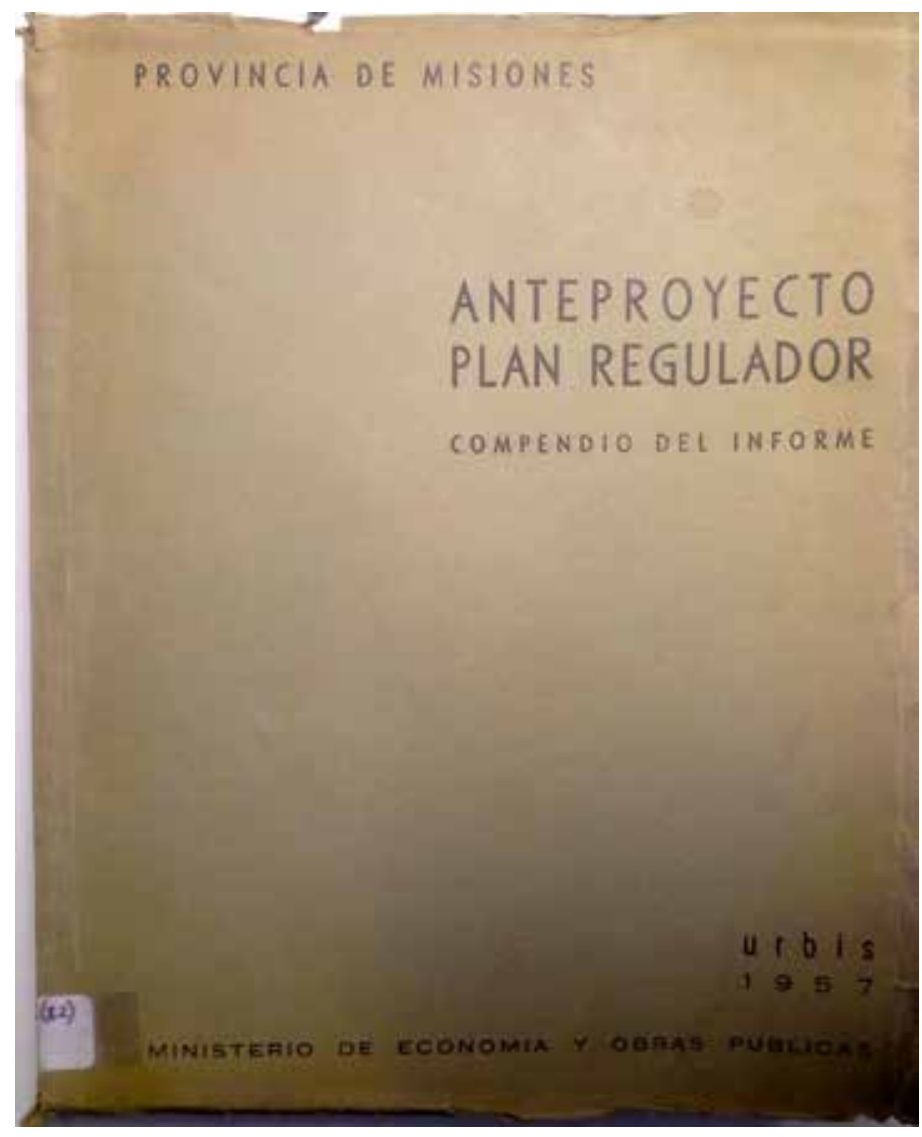

$1-2$ 


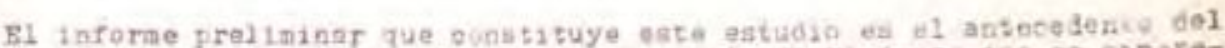

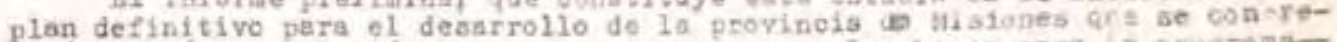

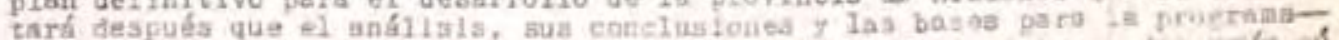

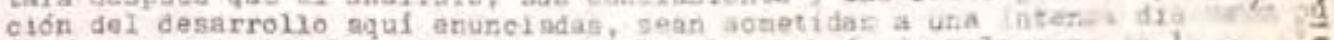

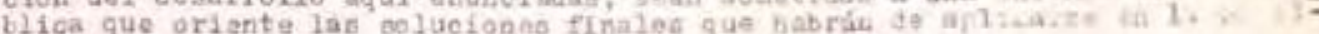
ficaotón proyectada.

B1 estudio se enouadra, on to referente a la thenlea de progrdenolón, a

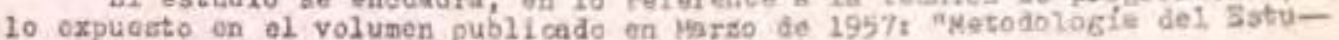
dio del Planeamiento de la Provinela de Misiones".

Las serias lagunas que otroge la información estad fotica oon quo se dirga ta para la elaboracín de log andilsis pormito nol anonte 11 par 8 cuncluaiones que reflejan valores relativos $y$, consecuentersente, los prograna a de dersa rrollo no son más que tendencias generales mostradas on función de los oonoli giones del análibia realizado on las oondioiones antedichas.

Blia no obstante, el pariodo de discusión a que de somete elizntorme peí mitirá adopter por la participaojón sctiva de todos los grupos sociales y ooo nómicos intoresados, las cifras y obsorvactones que no seen una representaclón.

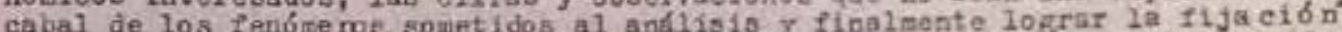
de bases 11 rmes de un programa sobre el conocioiento oierto del sujeto de lia plantizioaión.

Wo solamente para la observación de orden metodológlog ó tscpioo, slno porque toda planificación debe estar enraszada en el coplritu de $10 a$ havitartos de ia provinoig, es que la diecusión públioa debe ser intensa y amplia.

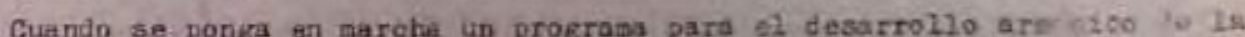
eoonomía y de in oultura de Misiones serf posible, medinste esta forand zo in

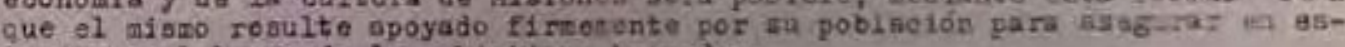
ta forma el logro de los abjetiva buseados.

Eata adhesión so ha de traduoif no solanente en un estuerzo conlig, indi

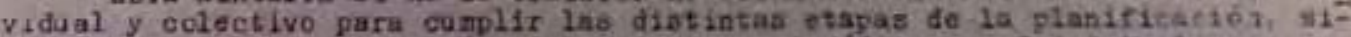
no también en la formulación de los i interas jurfalcos y adsiniotintivostueje sarios, dispuestob por 206 poderos publicos reprezentativos.

Bs necesarto hroer luega un eafueran alstendteo y.fime a travét del t leapo para la conoroción do lae sodsdas di apugathe en el plan, pero trmb íf

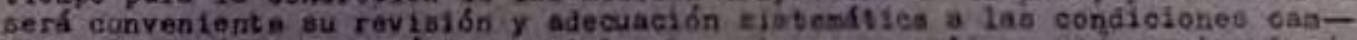
bientes del dabito econónico-bocial sobre al quen so aplica, para rentemrio vin oulado al miano pernsenenterente, avitundo anf un divoreio sicte lot glsists iva fendantios cuya barcha an quiere ordenar.

Conviane tener presents. en todo mosento, que los planee del zipa ge st proyecto, to dgben temer un curácter rigido y que dentro do las líneás do dez

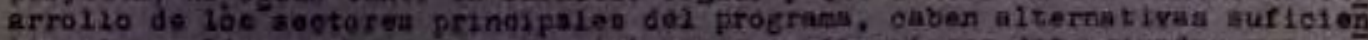

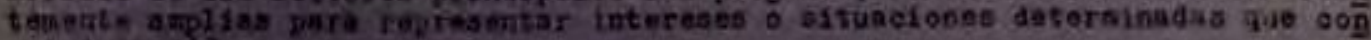
vatiga enaldenir. 

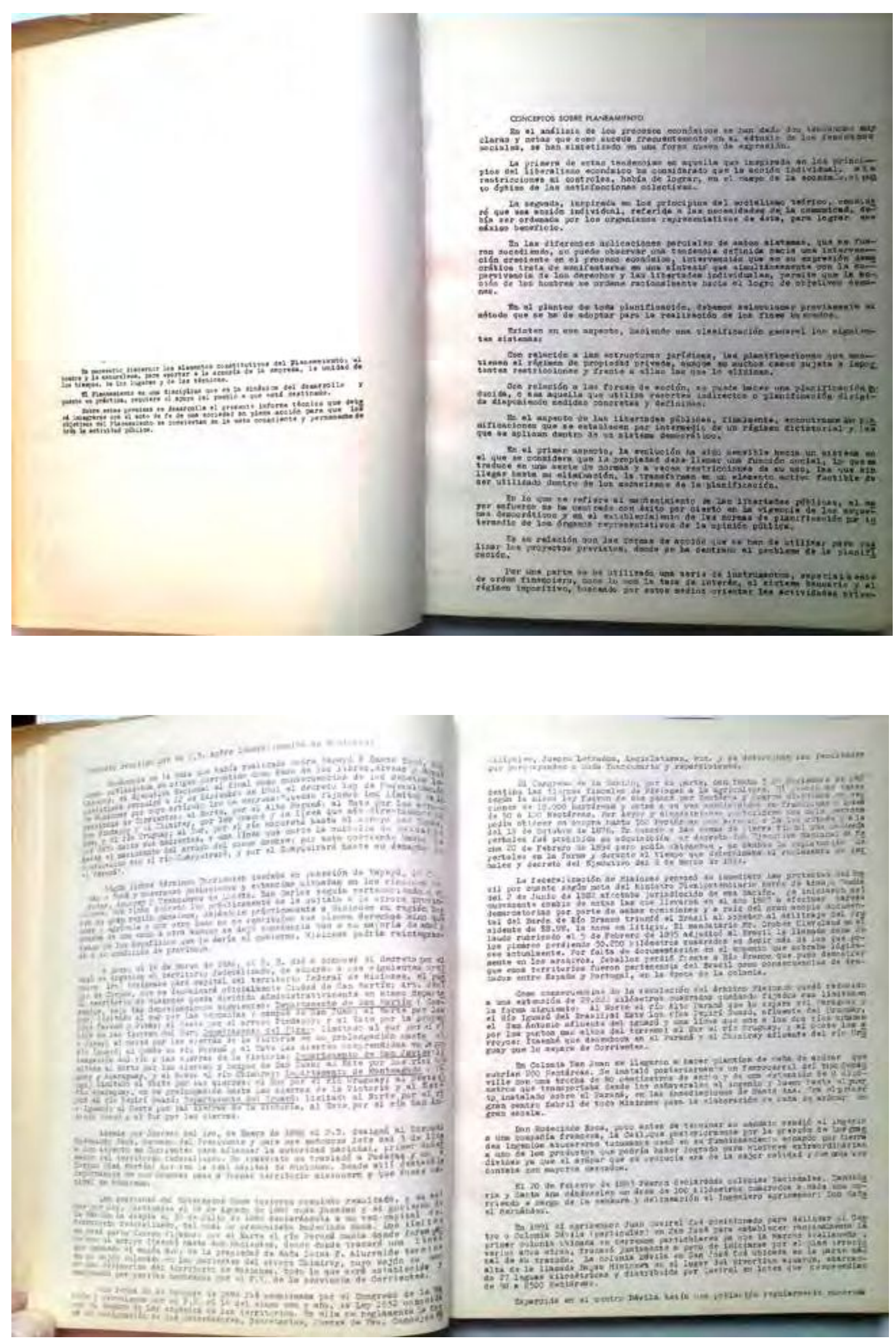

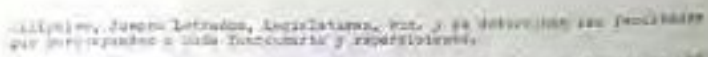

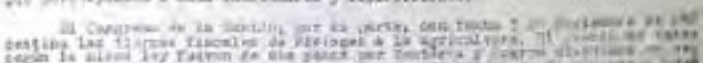

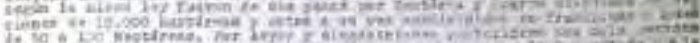
19.

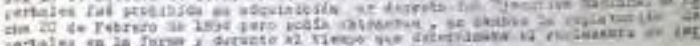

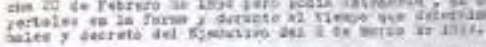

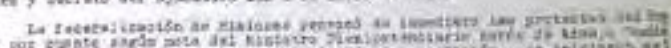

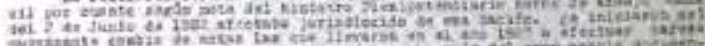

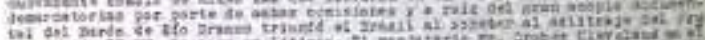

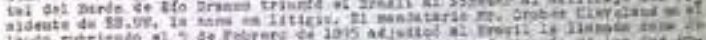

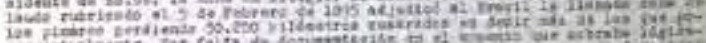

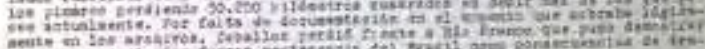

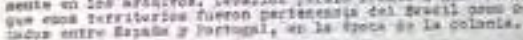

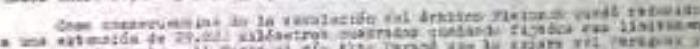

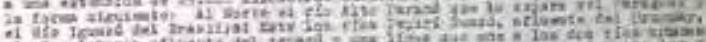

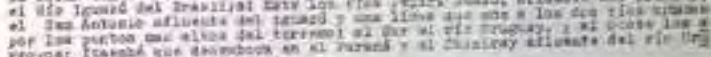

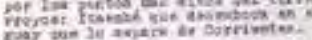

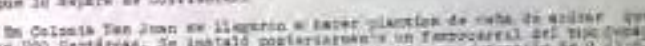

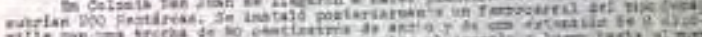

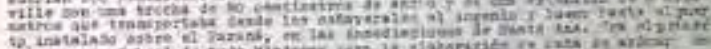

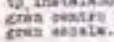

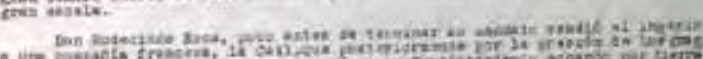

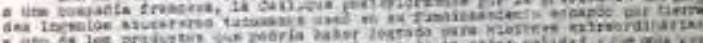

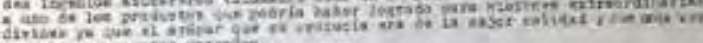

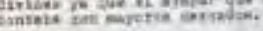

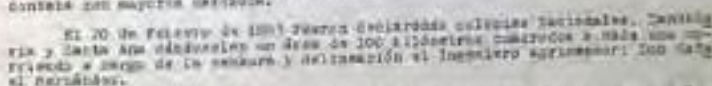

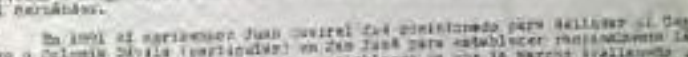

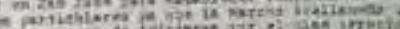

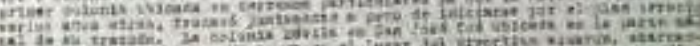

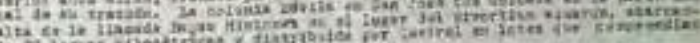
a.

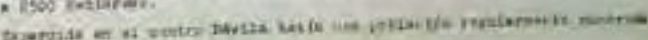

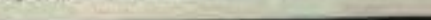


11. MISIONES HASTA TEIO

B1 fócinen Jesuítico, después qe là expulaion fué revmplazado por une $c c$

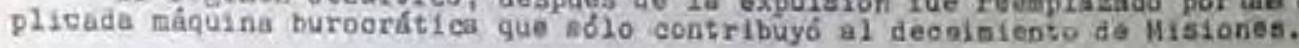

La provingla fué dividida en departamentos gobernados oói un Tenionto do

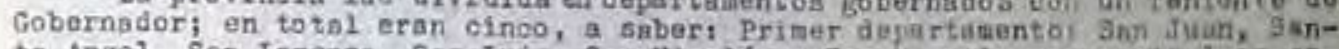

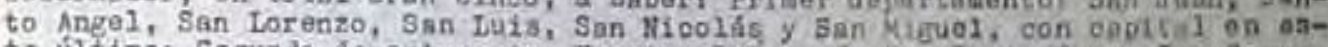
to último; Segundo departanento: Muestra Senloro de Po. Sunta Robay San Cosme, Santiago y San Ieniolo Guazú, con capttal en este dilieo; Tupeer bupartaminto:

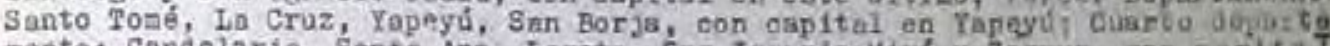
mento: Candelaria, Sante Ana, Loreto, San Ignnoio Minf y dorpus, gon o aplíl I

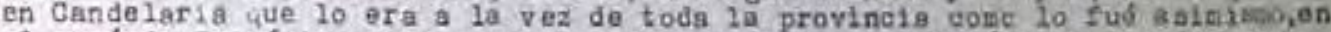
e1 perfodo Jesuítico; Quinto departanento: (10reado este vitiso por disposic16n del Bxcmo. Virrey Don Juan José de Vértiz) Apóstoluo, Son Carlos, Jan Jo sé, Santa Marís la Mayor, Mártires, San Javier $y$ Concedolón oon capitil an og te último pueblo.

En cada puoblo se deat gnó un adeiniotrador que dependía a wu vez del fa ministrador General oon sede on Buenos Aires. Por otra parta e1 aucerdote, y por último, el Cabildo indio (esto último yo existía desde al períado ya exie tía desde ol perfodo Ieruítico).

A 10 a pocon eños de In instalacírn del llamado rógimen de sucarelli, se designó un Gobernadar General que ten fa juriadicolón bobre los Tenientes le do bernadores.

La Bepjaración de poderes on cada puoblos religioso, Bdiministrativo, poIf́ico militar y comunal para poblaciones que, cono henos dicho no alcantaben t6́rmino medio 1083.000 habitantes, trajo conflifotos insalvables $y$, $\theta 1$ consi gurento desaliento de los habitantes. En efecto una disjos.oión del reniente Gobernador, casi slempre encontrabs resiatencia on el Adeinistrador o on los 은 tros poderes y por 10 tanto la erectividad en medidas oomunes no re nidia los frutos apetecidos. Los Administradores no hacian más que explotar en ou propio beneficio los bienes del pueblo. La Administración espiritual según las de partamentos se encontraba en panos de franciscanos o Dominicos, frdenes religiosas de concepoión muy distinta a la enseilanza que impartian los Jeauitas.

Así el indigena, comenź́ a sentirse desorientado ante tantas 6 rdanos di ferentes y al contempiar que wus frutos y haciendas, eron vendidas para oxolu sivo benelficio de squellos que gozaban de cnnonglas y que representaban a 10 más puro de la burocracia espaplola, trasladado a Asérics y con el desali ento comenzó la emigración.

Por otra parte, el azuzamiento constante de los indios charrúas, bohanea y yaros por parte de eaos mismos portugueses, para que atacaser a las eEtanoías avanzadas de $10 \mathrm{~B}$ guaranies a fin de robarles el ganado $y$ trunaportar10 ie territorto brasileifo, oroaban un olina de mayor desconoierto en Mialones. LOB indios más hábilea, músicos, srtessnos, etc, optaron por escapar de a ud pueblos y trasladarse a Asunción, Buenos Aires, Corrientes, Santa Fo, dozde, por su saber y sobre todo contracción al trabajo, encontrsban ocupación remunerada, no queriondo por 10 tanto regresar a 108 puebios que los viezon racer.

Y así comenzó $1 \mathrm{~s}$ decadenoia de la que fuera poderosfaibe provinoia Jesuftica. Si bien eate era el real estado de cosas en las Misiones, ios nonarcas en todo momento trataban de lograr eu bienestar con reales cédulas y epro bas ón de planes. Asl fué oomo ourgieron para la buena sdministracibà de Mibación de planes. Asl lué oomo surgieron para la buena saninistrasión de Mi Ribera, Félix de Azara, Virrey Aviles, eto. etc. 


\section{ESTRUCTURACION PROVINCIAI}

CUBSTIOH DE LIMITES GON BRASIL: Sn 1857, 14 de Dioiembre eI Brath $y$ in Argentina que luego de $3 u$ +1 lanza para derrocar a Rosa necesitaban aetulizar los limites en 10 que corresponoia a Misiones en su parte del Alto vrugay Fú así como se estableció a los ríos Pepiri Guszí y Sara Antonio, cobo ínites. No aleanzó ain embargo perfectibilidad jurfdica en virtud de no habera efectuado $\mathrm{g}$ c canje. Fracasado este priner aouerdo ia Cancilierfa Imporial rao nuda el intento en 1876 y en 1877 la prensa brasilenta ataca por 1 б penetrusiá de srgentinos en Campo Brf́, en las inmediaciones de Palmas Novas. Irigoya que tuvo a su cargo la defensa argentina incluso qujere lilegar al arbitraje y vachaza la tesiz del "utir posaidetig". Bi Brasil en viata de que no se puede He gar a nada concreto retira a su comisionedo y queda asi cerrada la disousibn:

El Brasil entre tanto esperando que is Argentina se viese envuolta an 11 nis Euerra civil, mandó en 1881 establecer coloniag militaren on la zont do 100 ríos Chapecó y Chopim.

Lógicamente el gobierno de 1 a molón vefa como base fundarental paru dis putarle ese territorio que Kisiones dejase de eatar bajo la órbita corratinā $y$ pasase definitivamente a poder de la nación. Adenfs desde hacfa sfioz se hi bie ahondado la rivalidad entre Buenos Aires y Corrientes por la posesión de 1o que otrora fuera provincia de Misiones.

Se hallaba asimiamo como Presidente de la Nación en 1881, el nx-Ministro de Guerra de Avellaneda, Julio A.Roca quien no podí olvidar lagieanente ia posicion de Corrientes frente a su gandidatura.

Por un lado el asunto Bressl y por otro posiblemente su resentimiento pa ra con eas provincla, 10 movio a presentir el proyecto de ley del 5 de tulío de 1881 por cuyo artfoulo único do dice: "Declarase nacionnl el territorio de Misiones, cuyo Ifinite al oeste quedarf fijado por el cauce prinoipal del rfo A guapey, desde su desembocadura en el Uruguay" hasta el paralelo 28 de Latitud sud y de alli por la If́nea meridiana hasta el rio paraná".

Cssi de inmediató Gúlino, al comprobar lo inevitable de la foderaliza-

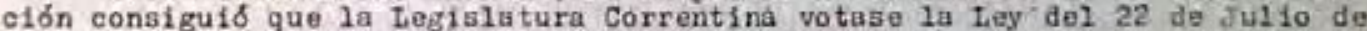
1881 por la cual autorizaba al Bjecutivo de ese estado a enajenar todas las tie rras piscales de Misiones a razón de lotes de 25 leguas. Las tierras se vendieron en una extensión de 750 leguas a sea la friolera de $18.750 \mathrm{k} 116 \mathrm{mot}$ ros ouadrados. Muy poco conocido tue ol maga sobre ol qua se hizo lis venta y aunque ia intenoión del gobierno provineial, al devolvor Misionos, que habla retenldo an su podor durante algunos affos, fué la de entregar al cobjerno facid nis, unicamente la juridicción del territorio pero despojado en absoluto de la propiedad. Por informaoiones que suminlatro el Bjecutivo Nacionn 2.1 a comisión nacionsl de lfuites que intervino en la delinitación de la frontera con al Bra e11, reaulto que se hable salvado del reparto, dentro de la regín boscosa, ás de 900.1 eguas cuadradas.

81. producto de la desatinada venta $\mathrm{ni}$ alquiera ingresó en las aroas pro vinclales. Algo, aunque pooo, ae salvs zin eabergo: el deoreto reglamentar 10 de la Ley oltada (deoreto de Julio 28 de 1881) dispuso en su artfoulo 12:"Los terrenos destinsdos para puebloa por Loy de 1877 , continuaran reaervados para ol mismo objeto".

Bn Setrenbre de 1881 el Congresto ae la Naolón inició In conałderación del 


\section{Plan del grupo Urbis para la Provincia de Misiones}
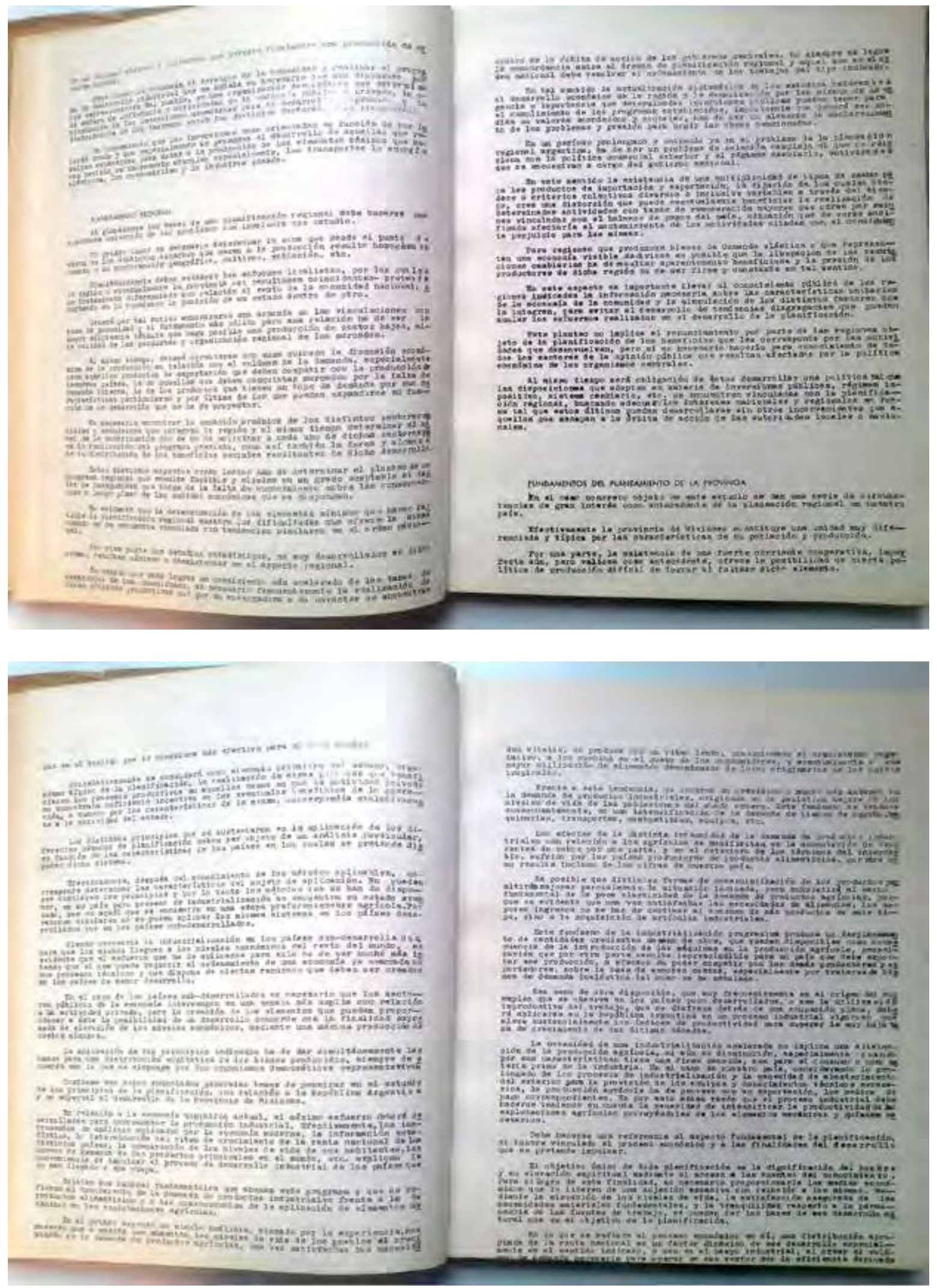

$8-9$ 


\section{Plan del grupo Urbis para la Provincia de Misiones}

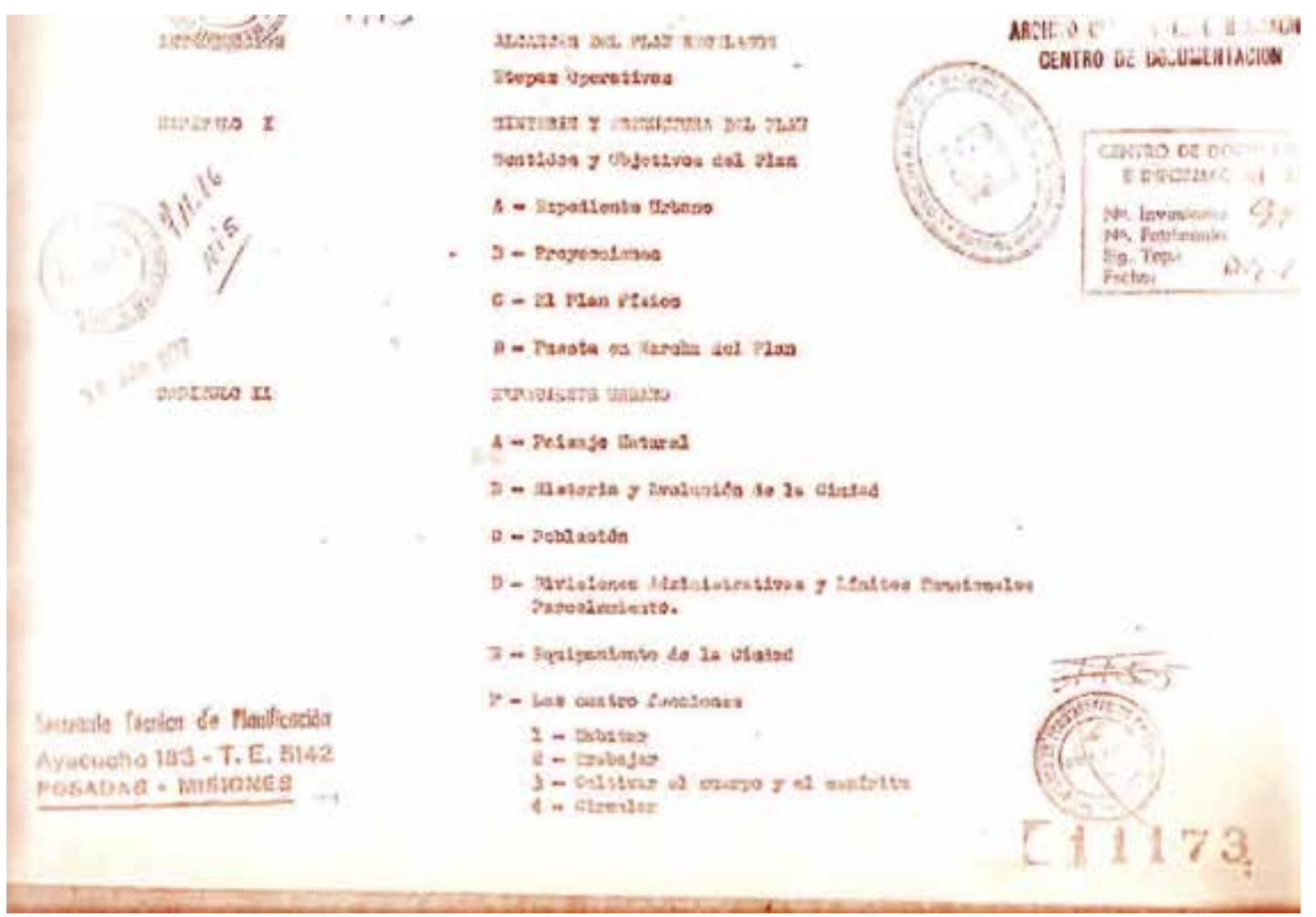

40

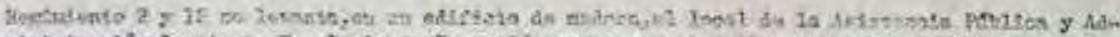

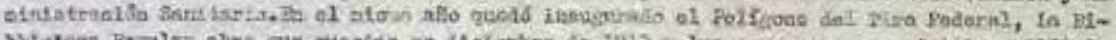

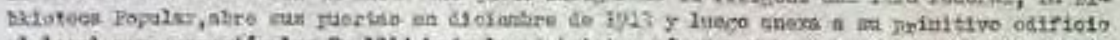

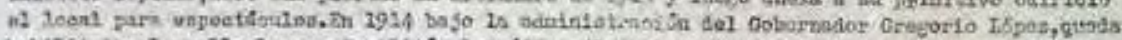

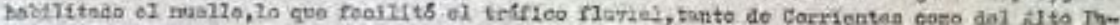

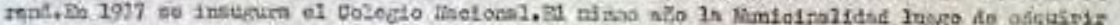

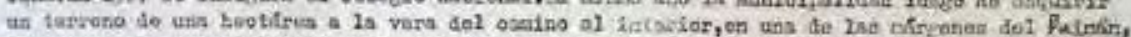

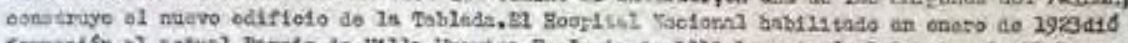

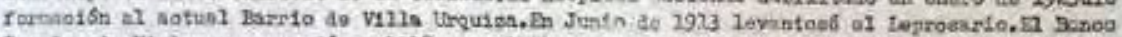

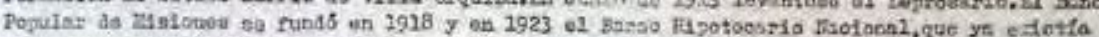

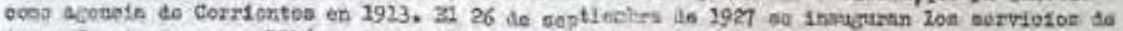

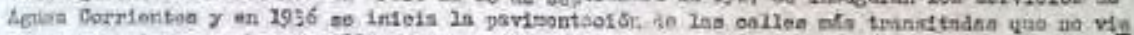

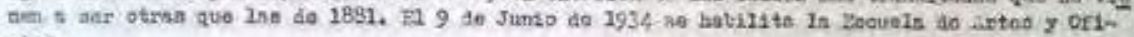
asos.

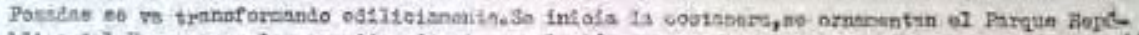

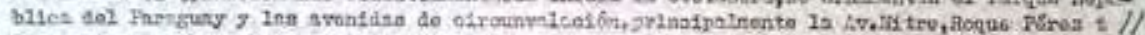

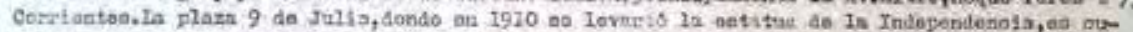

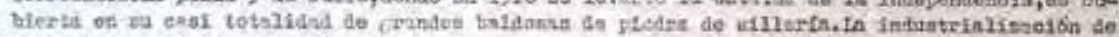

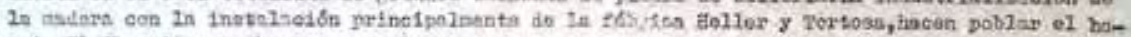

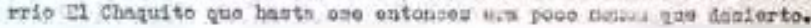

c. Pras.croti.

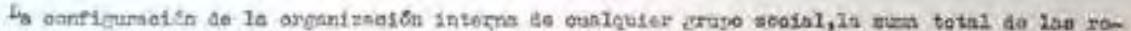

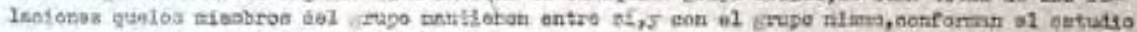

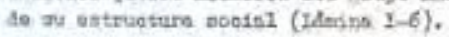

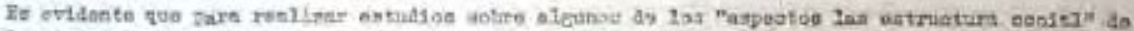

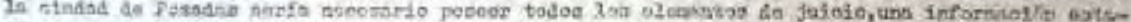

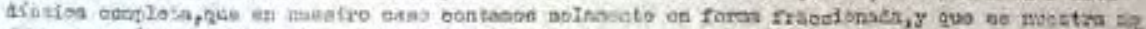

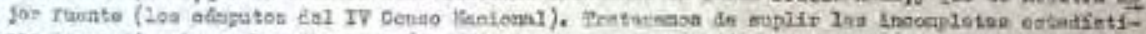

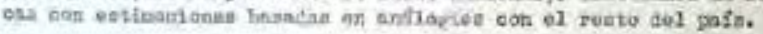

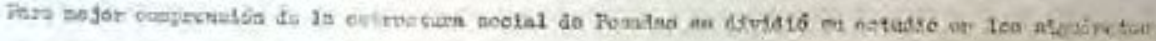




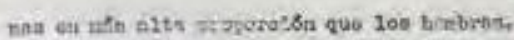

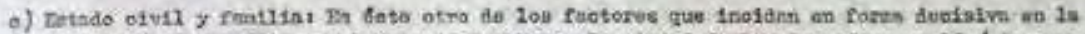

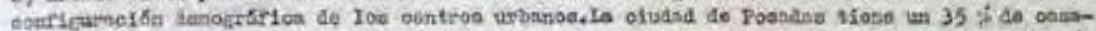

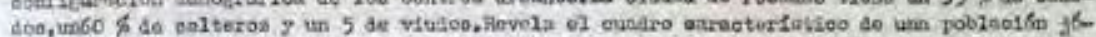

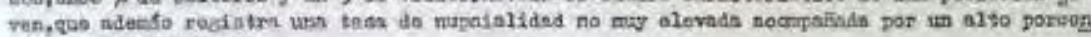
tajo do $111_{f}$ l tiridard.

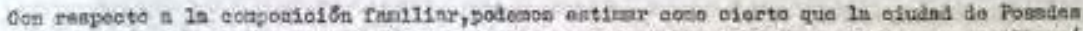

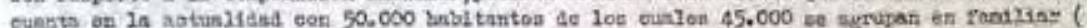

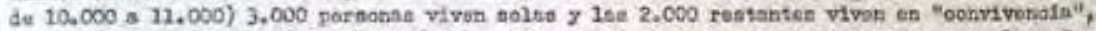

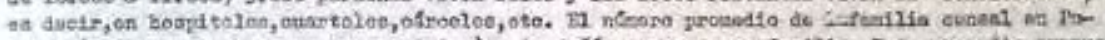

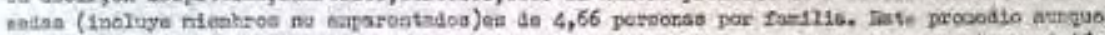

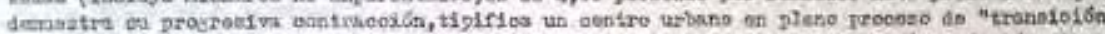

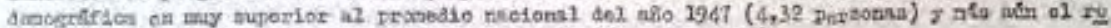

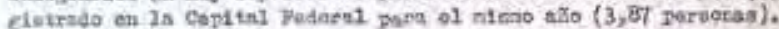

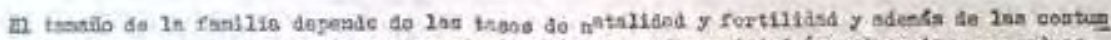

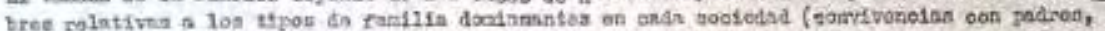

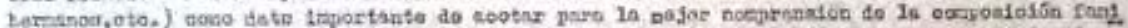

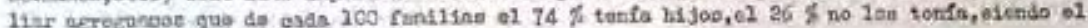

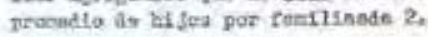

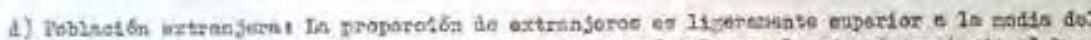

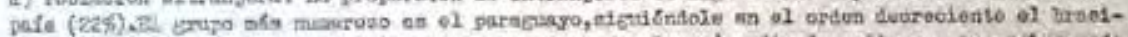

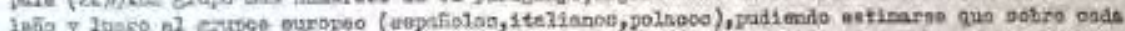

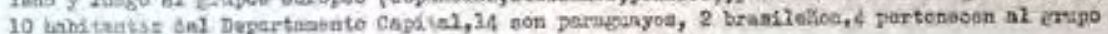

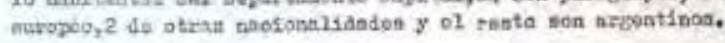

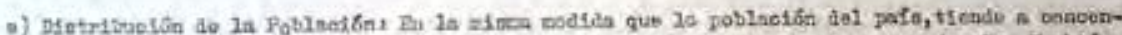

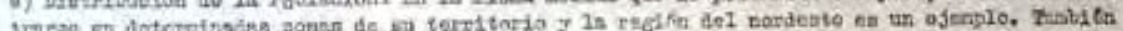

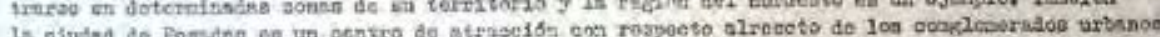

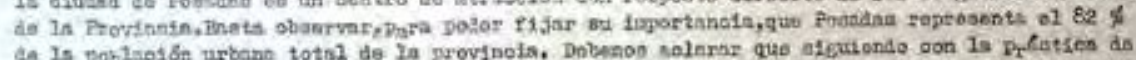

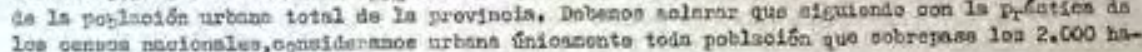
b1tanter.

$$
-73-
$$

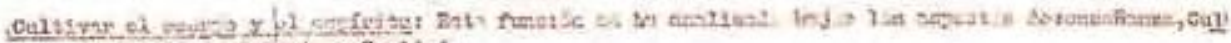

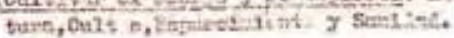

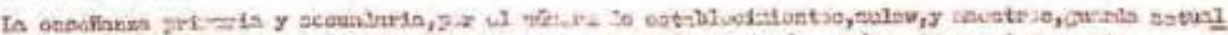

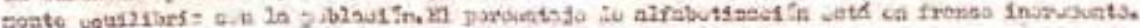

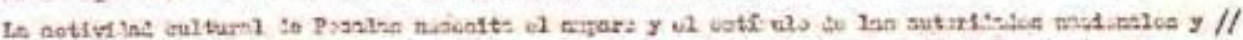

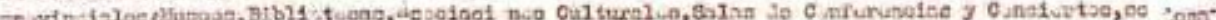

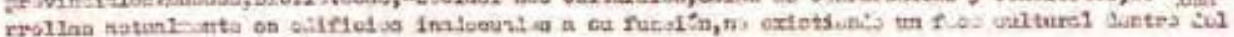
cabsto urbans.

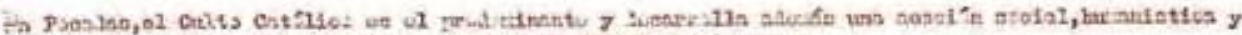
cultural os lua dietiat:e boot

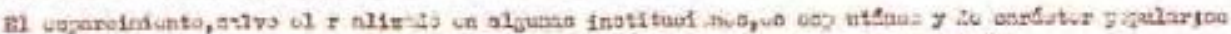

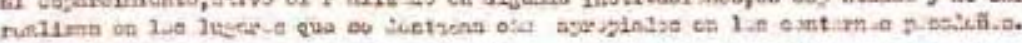

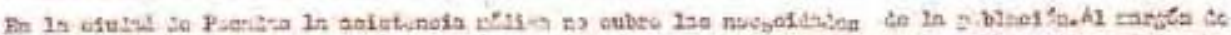

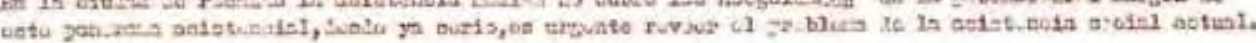

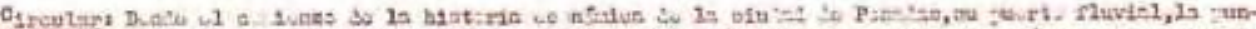

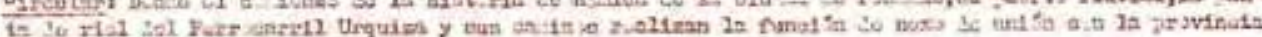
y 41 ruat: $6 \mathrm{a}$ zain.

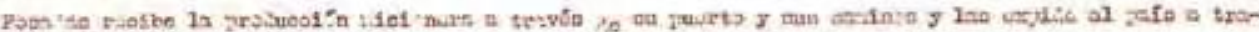

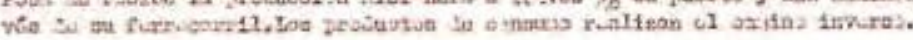

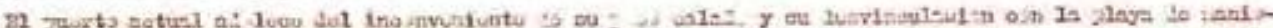

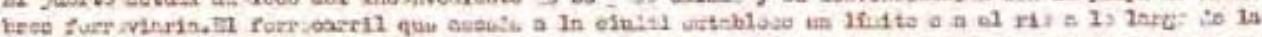

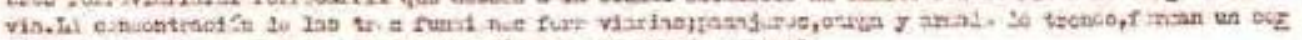

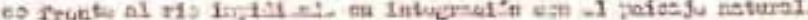

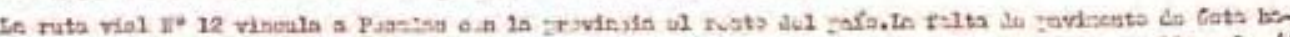

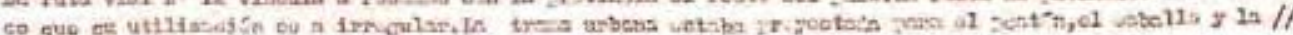

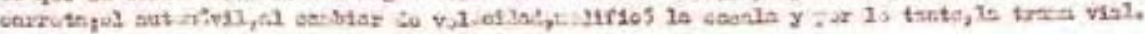

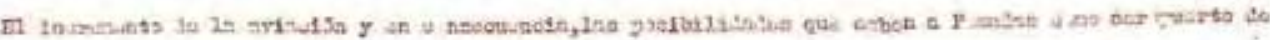

\section{ARCHNO CERTRA DE GCBRENA CENTRO DE DOCUNENIACION}


$-71-$

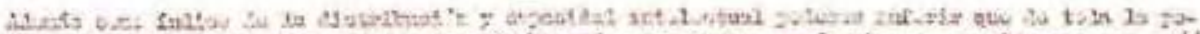

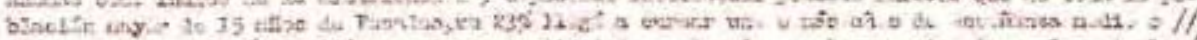

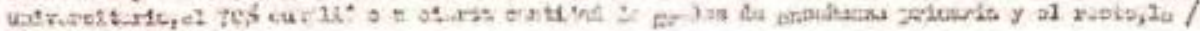

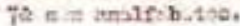

Pasenge drtwo

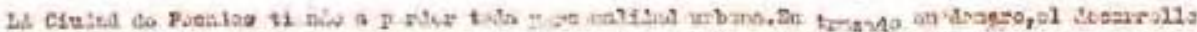

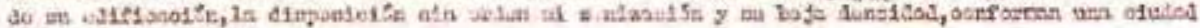
ala rabgere dootsciside.

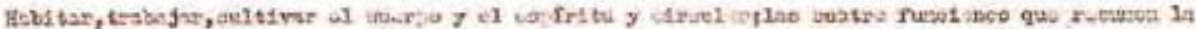

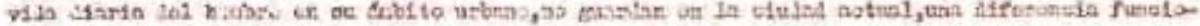
act.

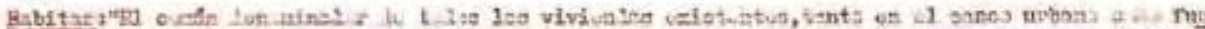

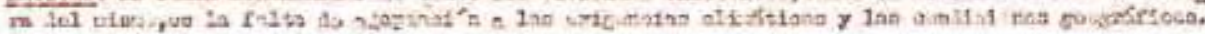

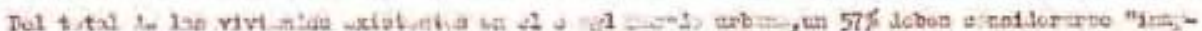

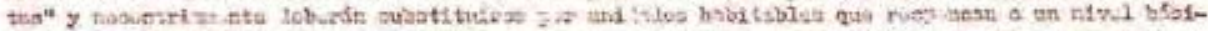

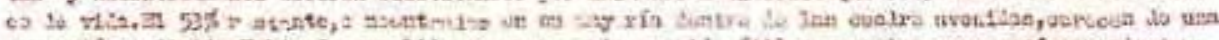

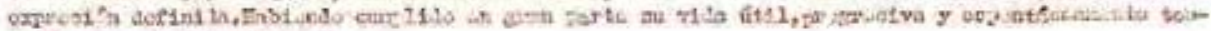

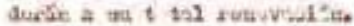

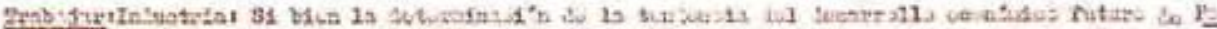

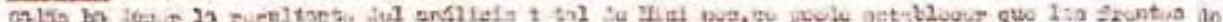

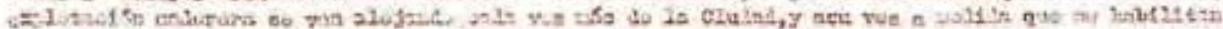

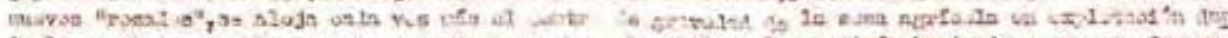

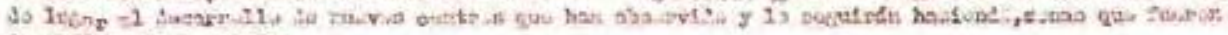

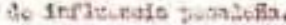

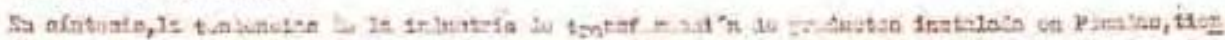

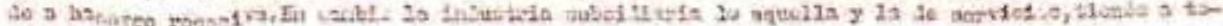
cas terstion.ine

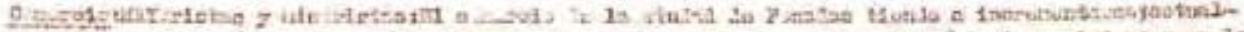

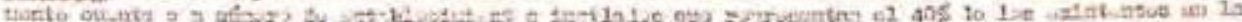

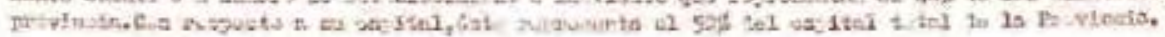




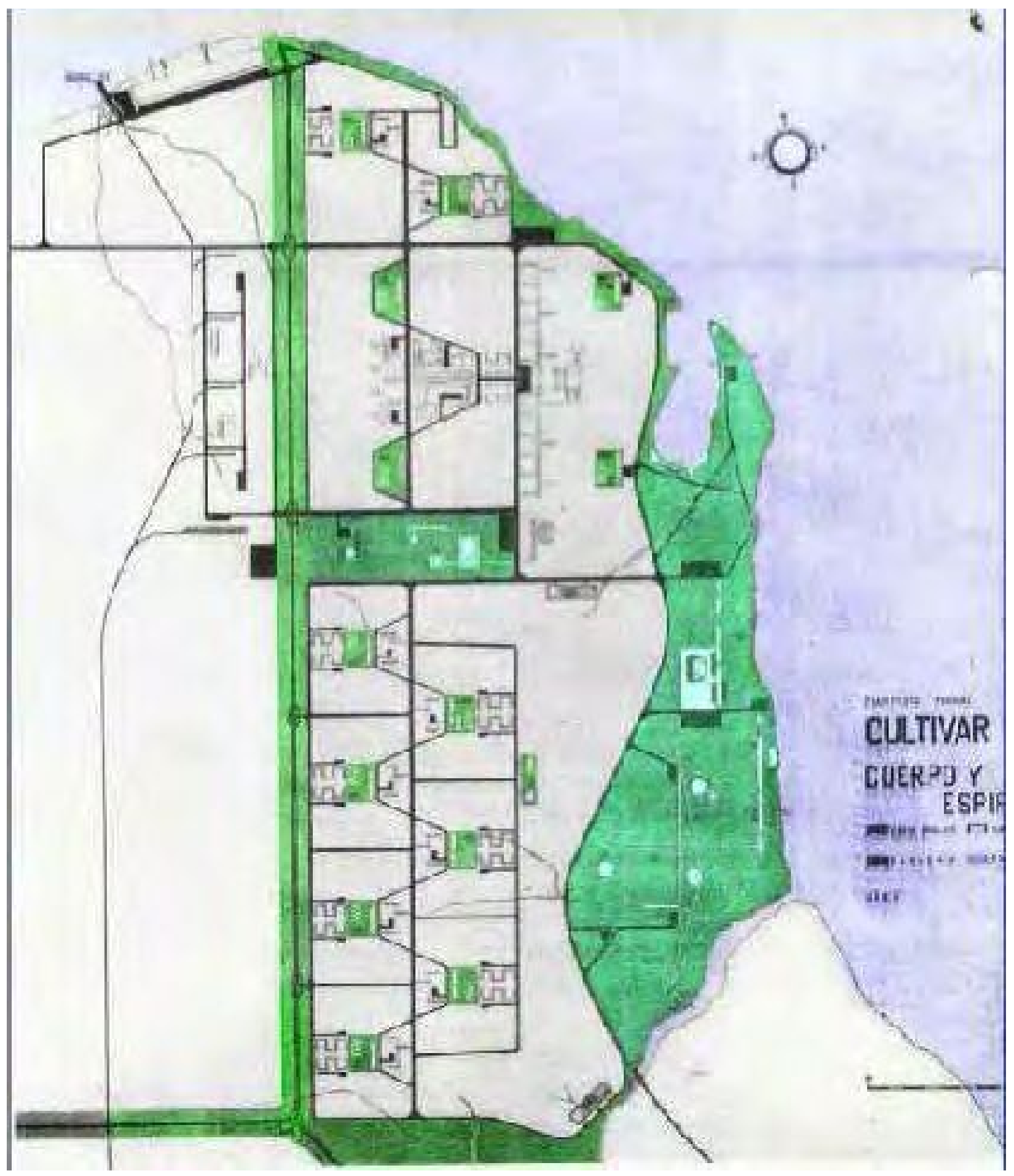




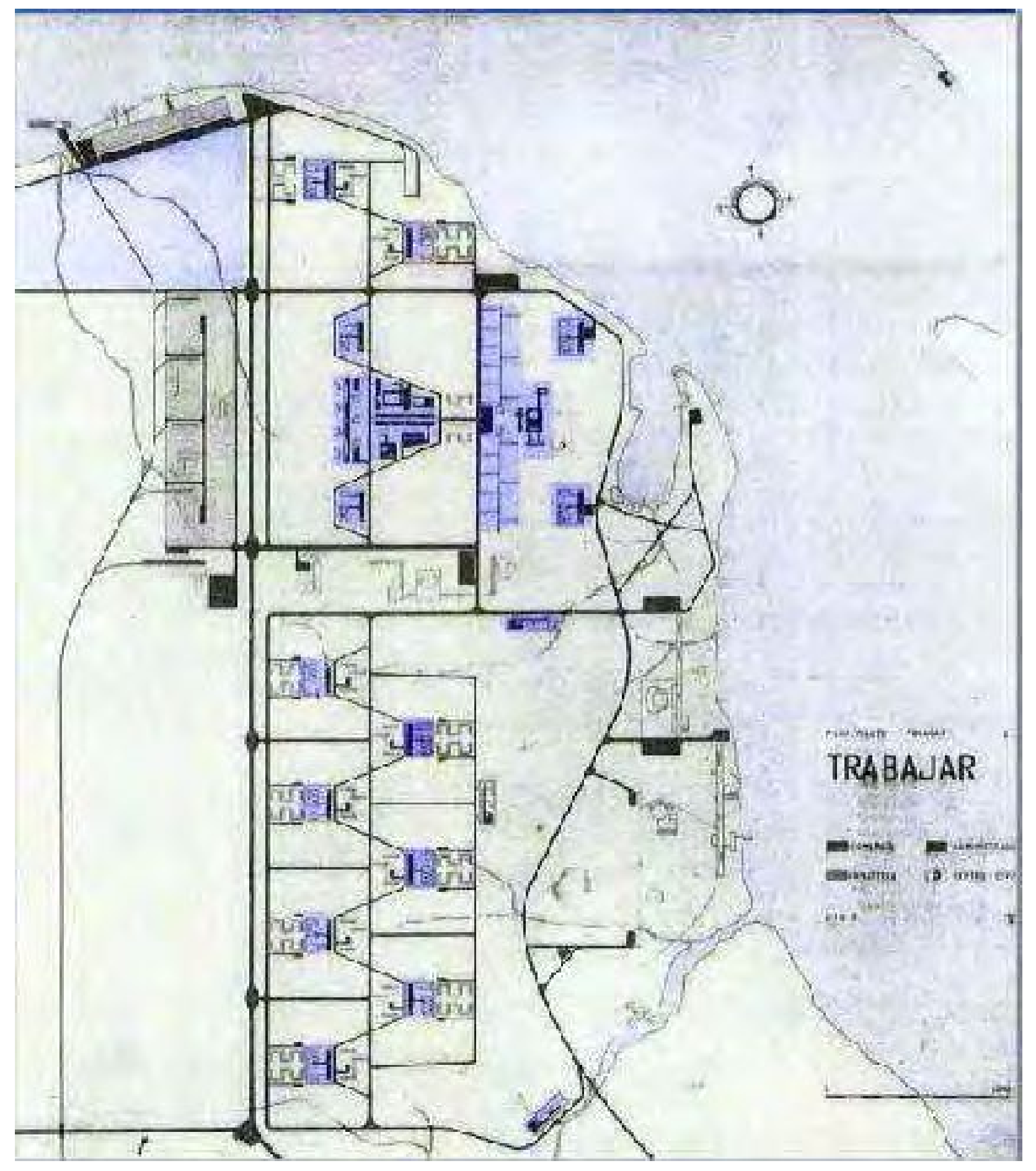




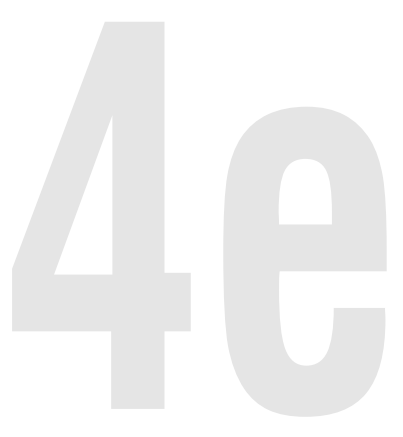

CUATRO ESCUELAS DE MADERA EN LA PROVINCIA DE MISIONES

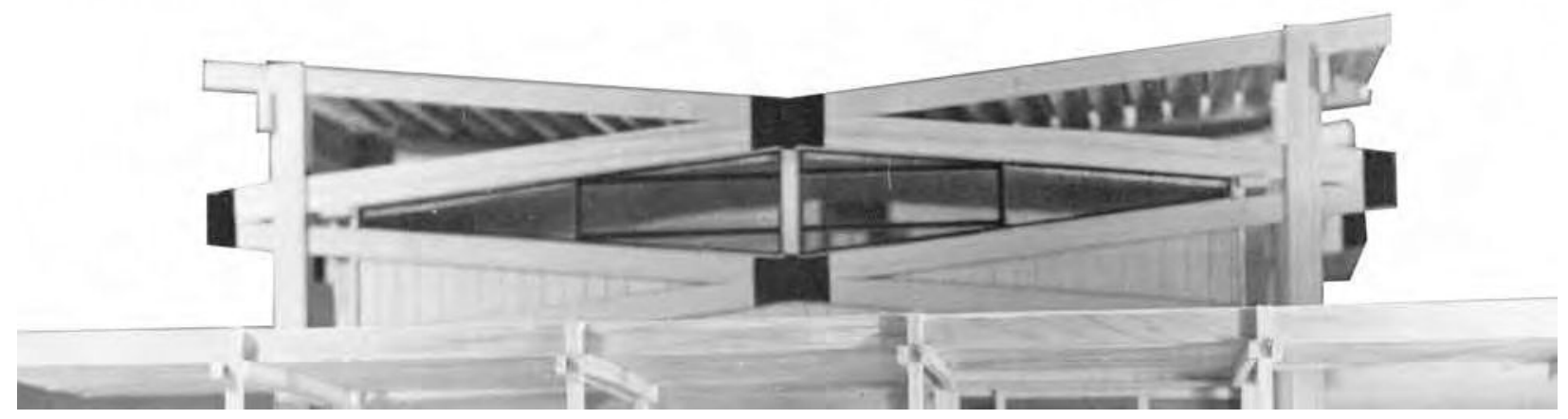




\section{Primer Plan de trabajos Públicos de 1956}

Las cuatro escuelas de madera en Misiones

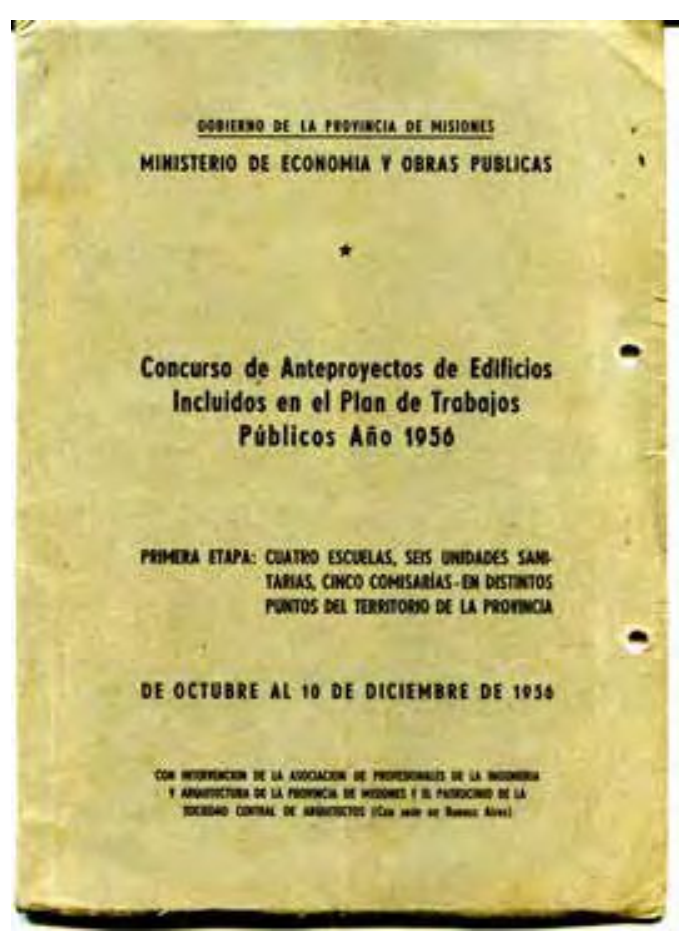

V-PROGRAMAS

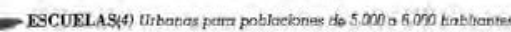

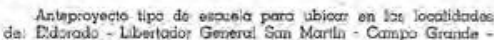

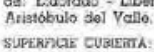

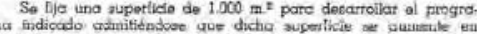
mat 5 ind

COATO AFMOXIMADO.

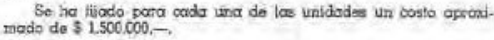

Trakencs

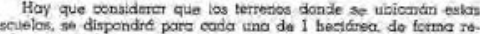
gular 7 superficie plone

mocrusu:

So detalla a continuación a' programe, indicando capockiojes

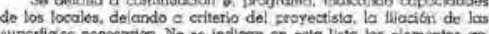

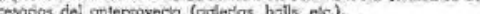
ENBEANREA:

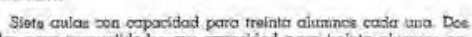

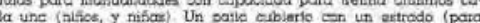

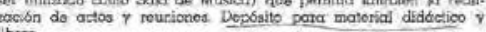

seavicios shatarires.

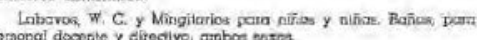
personal

Und ofleina pora Director. Und oflense para Socetrrlas. Sals de IRdestros $Y$ sedo

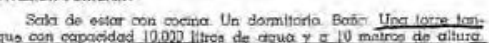

$$
-28-
$$

Intervención Nacional en la Provincia de Misiones

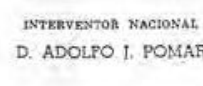

MISISTro DE GOMHERso

D. TUAN I OLMOS

Subvecretario: D. PEDRO D. REROLLO

MTNBTEO DE $2 \mathrm{X}$ ORRAS PUELCOAS

Dr. IULIAN FRANCISCO FREAZA

Subsectetario: ING. IOSE ENRIOUE BERTRAS

YINISTRO DE ASUXTOS ROCAALES

Dr. ROBERTO DEL CASTELU:

Subaecratatio: D. TUAN C. PZZario

SBOAETARIO GEMERAL DE LA GORERNACTOS

D. RLFREDO PIRO

1956

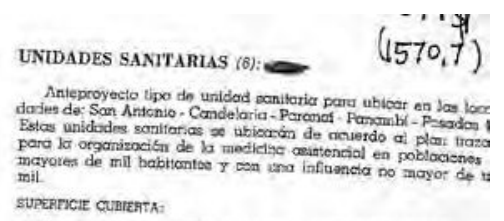

SUPEREGIE CUARETTA

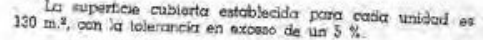

COSTO APROXIMADO:

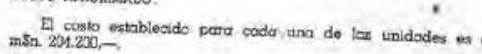
TERTENos:

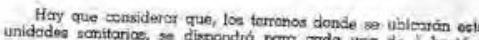
unidadoa somitarios, se dispondtá parc sada una de $I$ hadán ГвоGлАM:

So des deralla a continuació al programa, indicands copacia

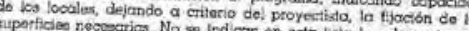

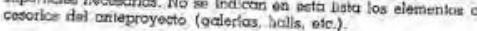
A.STTENCTA MEDICA:

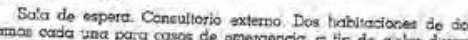

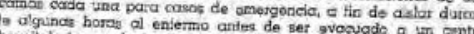

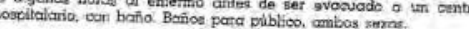
SCCION SOCIAL.

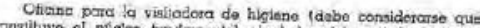

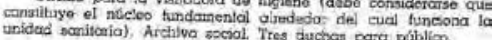

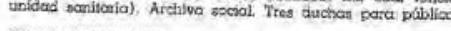
SERYYCIOS GENERALE:

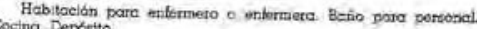
Cocina. Deptétio.

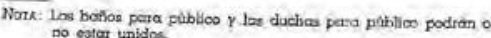

$$
-29-
$$


oviscia doe Misjonic.s

ERIO DE ECONOMIA

JERAS PUBUCAS

RectosTAB

28. Preration

TRABATO He 216 \%

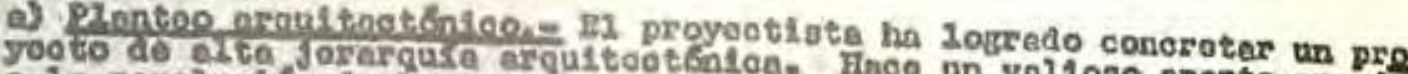

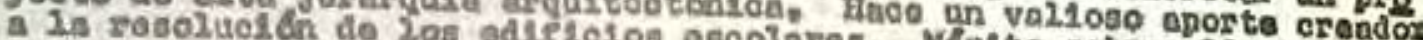

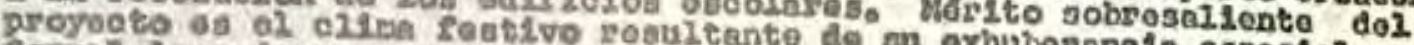

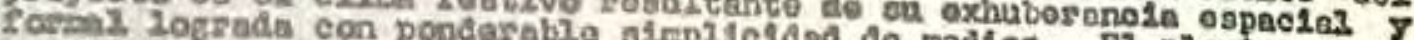
Eamones oxterog logrindo

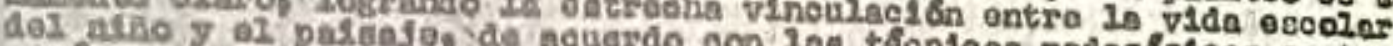

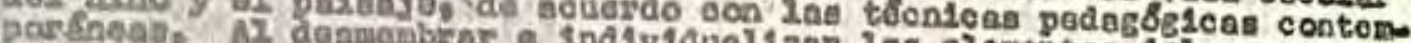

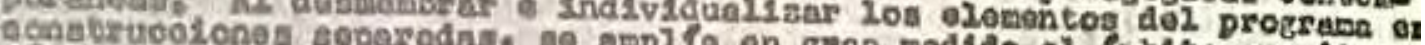

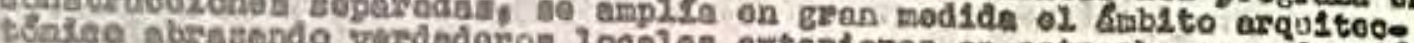
ylams. $y$ do uso von

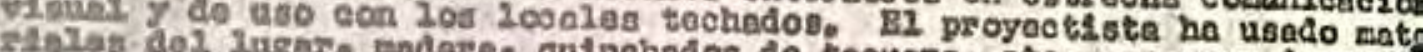
vo 8 orden.

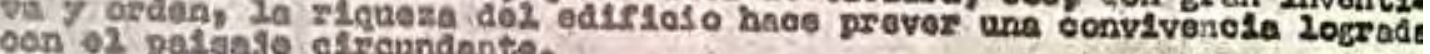

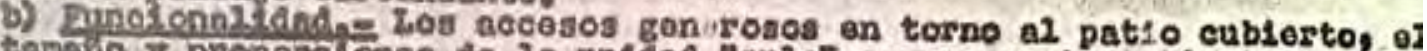

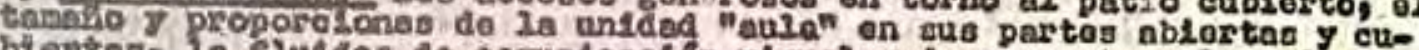

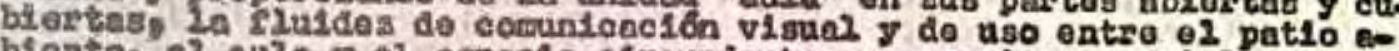
bierto, of aula $y$ el eapooso esroundente gon econtos ospocialanta deg. tecablos gontrs de un maroo Inobjetablo para ol doaarrollo ozeador do

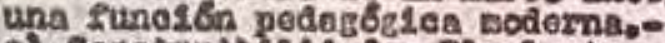

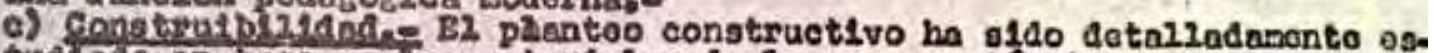

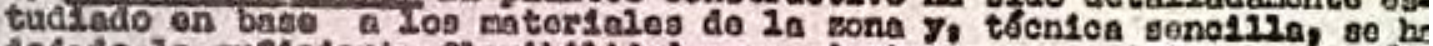

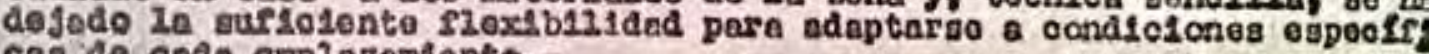
cas de caqa omplezamionto.

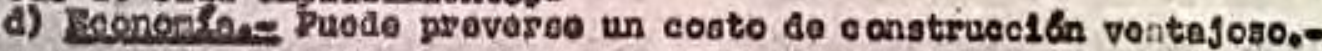

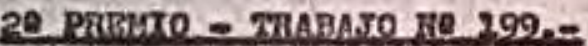

a) Planteo araulteot 6 nseo: $\mathrm{B1}$ proyoot1sta ha desarrollado ol progroma

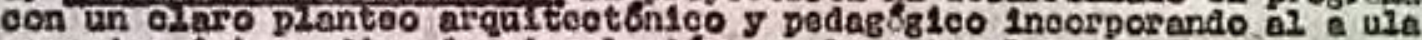

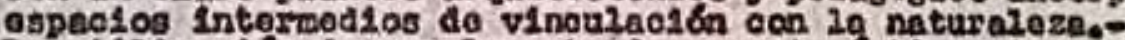

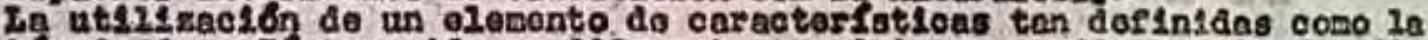
bóveda do earion corrido on diforentes posiolanas conflere ansdad y dinantamo as conjunto.

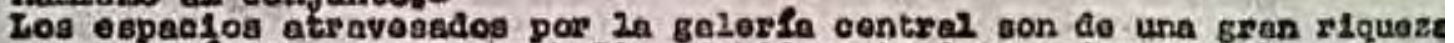
arquiteotóniea poro no so halien dobldamonte Integrodos con os patio o. biterto que a sa ves careco do definsosona

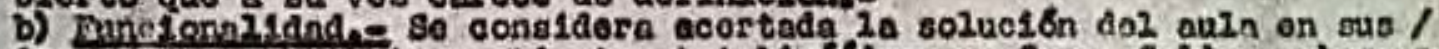

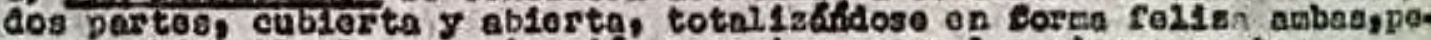
ro os objetabia in comunicacion mosquina ontro las nianas partos.*

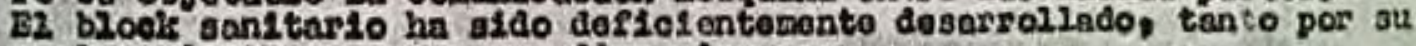
ocmlazarionto corotpor arg Almonglonas.-

Es coltioablo is ubicaoión del patio cublerto on rejiolón con las aulai F do dudoso aprovochasionto para conourronclas nunoroses agravado por clo rolativerento oxigua -

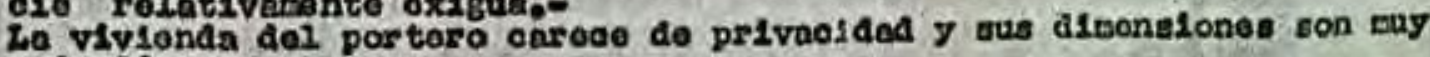
reduolaba

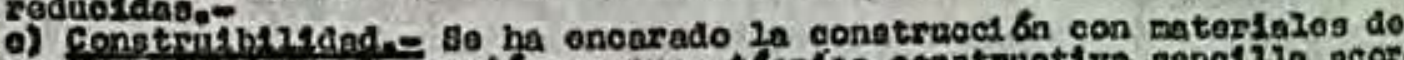

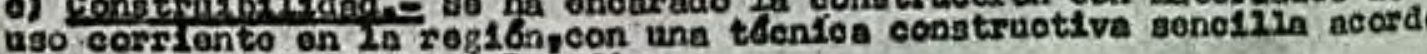

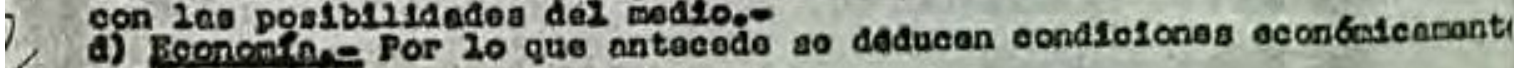
vantajosase-

1II.

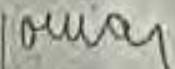


EL PROBLEMMA - LA SOLUCT ON ADOPTADA:PARTIDO. CONSTRUCCION

\section{EI Problema}

Clima: Dadas las caracteristicas especiales de la zona donde estarán situadas estas escuelas; a saber: clima tropical con un inviepto sin rigor seguido por una corta primavera en el mes de-Agosto y una larga y bochornosa estación estival; vientos muy marcados; radiación solar intensa y recorrido foz sol en estas latitudes; lluvias copiosas;abundancia de insectos,etc. Se desprende 'la necesidad de contar con eficaces protecciones contra estos elementos que comportan determinantes de importancia. Así como el aprovechamiento máxime de sus condiciones/favorables, $\in$ procura de un mínimo confort para el desarro110 de las actividades humanas.

Paisaje: Ya que los nucleos urbanos donde estarán emplazadas estas escuelas han modificado con anterioridad el paisaje es imposible'establecer una relación rígida entre el elificio y este su nuevo escenario, dado que cada una de las cuatro localidades presentará con seguridad planteos diferenciados.

Por lo tanto no se' ha considerado la relación escuela-paisaje en forma absoluta.Solo se desea establecer que dado - el tipo de clima este podrá contrikuir a una remodelación de los terrenos elegidos en cuanto a vegetación y que esta a su vez posibilitará la regulación de dicho clima.

Material:Es importante destacar que son datos del problema: Ia dificultad de los transportes por caminos y puentes, Io que pone en desfavorables condiciones a las poblaciones del inter or con respecto a las costeras y la falta de mano de obra especializada. Como condición favorable en cambio 
se cuenta con ciertos materiales existentes en todps los emplazamientos:maderas, tierra para mampuestos y caña.La utilización de la piedra existente es desechada en parte por la falta de aglomerante en la región.-

Construibilidad: Los datos y hechos enumerados en los apartados anteriores indican que el problema en este aspecto consiste en la inconveniencia-de elegir metodos constructi-

* vos y materiales que no sean. Ios ofrecidos por la región y ya conocidos por la mano de obra existente.'

Plano Tipo:Se ha considerado al plano tipo, como una idea unificadora de criterios conceptuales, funcionales y constructivos, pero sin que se constituya en una solución rígida que no permita la adaptación a los distintos problemas particulares que presentara cada localidad, ya sean en cuanto a forma del terreno,ubicación, pendientes, etc.-

El aula: Se ha pensado que el actual problema del aula en esta escuela' se puede desglosar en dòs aspectos: el aspecto físico,que consistirá en solucionar los problemas plantea$\because$ dos por el clima, y por otra parte el acondicionamiento' pedagógico,que conşiste en obtener aulas que si bien respondiendo a las exigencias de los actuales, métodas y programas en vigenciá,pedán servir a los métodos de enseñan za mas modernos que se estan experimentando en la actualidad.-

La escue la: La escuela consiste en un problema donde a los anteriores considerandos se acumulará el de la perfecta determinación de los espacios funcionales por medios arquitectóni$\cos \cdot-$

\section{La Solución Adoptada:}

Criterio: De los elementos de juicio brindados por el planteo del problema, se infirió que el criterio a seguir en la solu- 


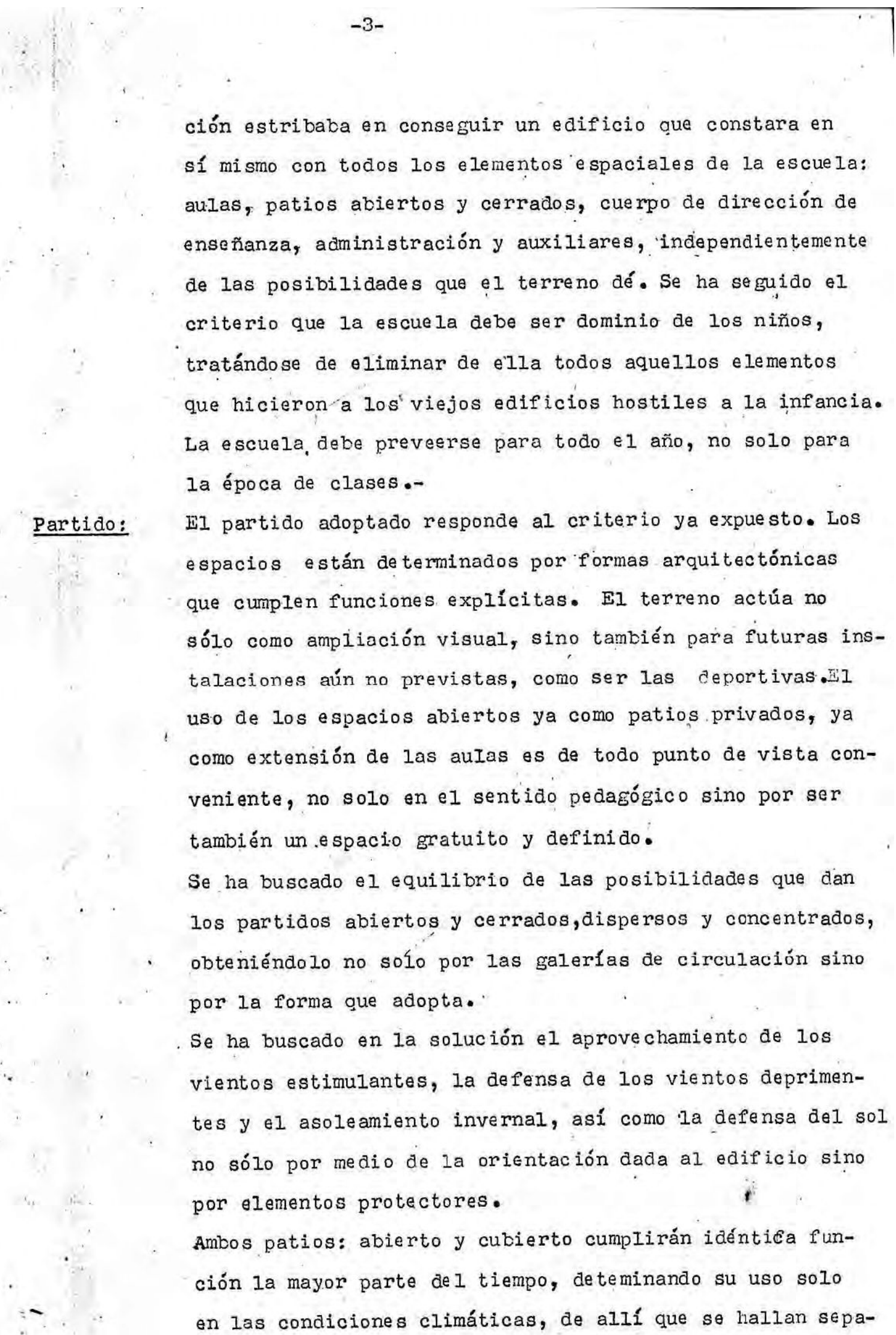

Partido: El partido adoptado responde al criterio ya expuesto. Los espacios están determinados por formas arquitectónicas que cumplen funciones explícitas. El terreno actúa no sólo como ampliación visual, sino también para futuras instalaciones aún no previstas, como ser las deportivas. EI uso de los espacios abiertos ya como patios privados, ya como extensión de las aulas es de todo punto de vista conveniente, no solo en el sentido pedagógico sino por ser también un espacio gratuito y definido. Se ha buscado el equilibrio de las posibilidades que dan Ios partidos abiertos y cerrados, dispersos y concentrados, obteniéndolo no solo por las galerías đe circulación sino por la forma que adopta.

Se ha buscado en la solución el aprovechamiento de los vientos estimulantes, la defensa de los vientos deprimentes y $\in I$ asoleamiento invernal, así como la defensa del sol no sólo por medio de la orientación dada al edificio sino por elementos protectores. Ambos patios: abierto y cubierto cumplirán idéntiea función la mayor parte del tiempo, deteminando su uso solo en las condiciones climáticas, de allí que se hallan sepa- 
El empleo de madera, ladrillos y tacuara, con formas constructivas simples además de abonar a lo ya establecido anteriormente, contribuirá al logro de costos bajos, dado que responden a los sistemas empleados comuninente en la Provincia.-

Con respecto a la construcción del techo de las aulas, se incluye en esta memoria un gráfico explicativo. Lste está formado por vigas trianguladas de alfajías unidas a pies derechos también de madera, arriostrados lateralmente. Sobre estas vigas apoya la cubierta y un plano de protección contra el sol permitiendo además a través de ellas la iluminación y la ventilación. A su vez las aulas están arriostradas entre si por vigas.Los tabiques tanto exteriores como interiores son de madera a excepción de los de mampostería de ladrillos correspondientes a locales sanitarios.El piso ha sido elevado de la cota del terreno natural, Io que es aconsejable en estos climas, piojiendo hacerse esto por medio de un entablonado de madera sobre peque rios pilares o por un contrapiso. 


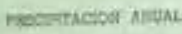

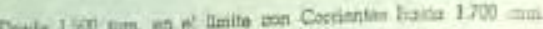
en cbots y 2000 num en $\sin$ Xutonia.

मccurtichas uensul

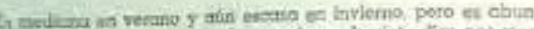

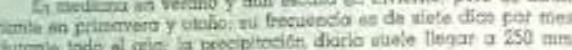

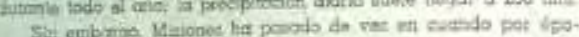

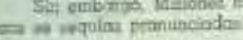

citak

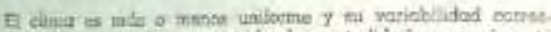

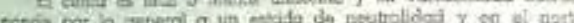

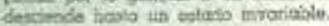

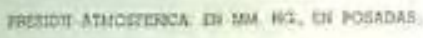

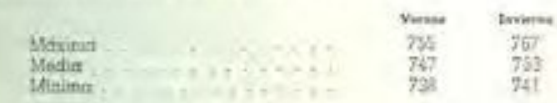

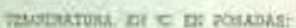

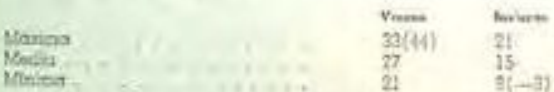

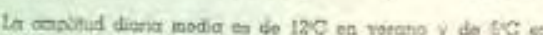

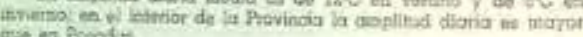

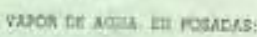

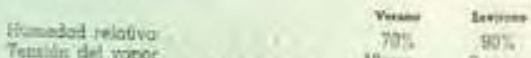

$$
\begin{aligned}
& \text { 11. 18me 9om }
\end{aligned}
$$

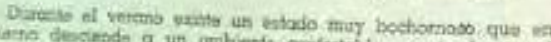

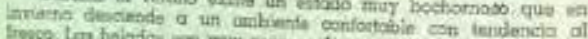

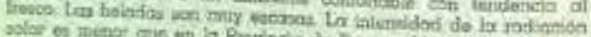

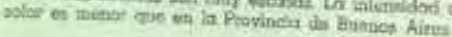

$$
-24-
$$

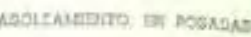

Nithosiad

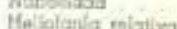

Hosolanio mererie?

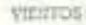

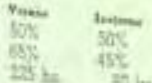

235 ist

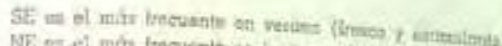

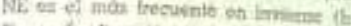

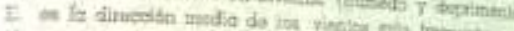

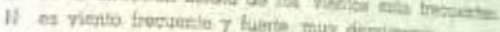

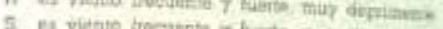

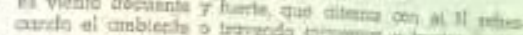

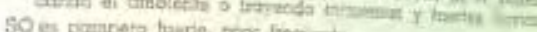

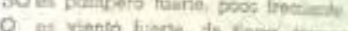

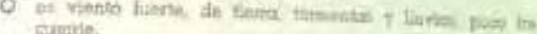

toprotite

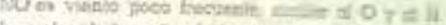

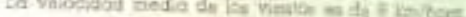

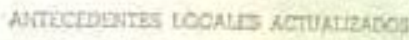

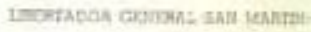

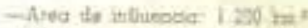

- Poblasión uriena: 2y00 hatthuine

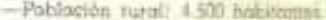

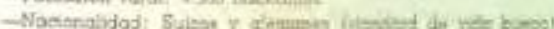

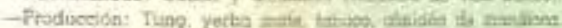

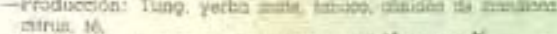

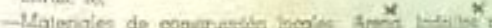

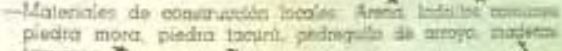

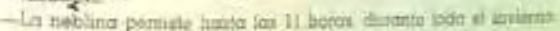
Etwonudo:

- Aisa de infiuenciat $700 \mathrm{~km}$

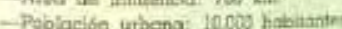

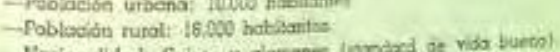

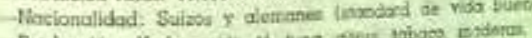

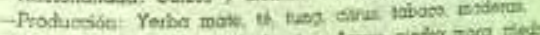

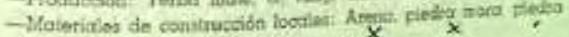
$-25-$

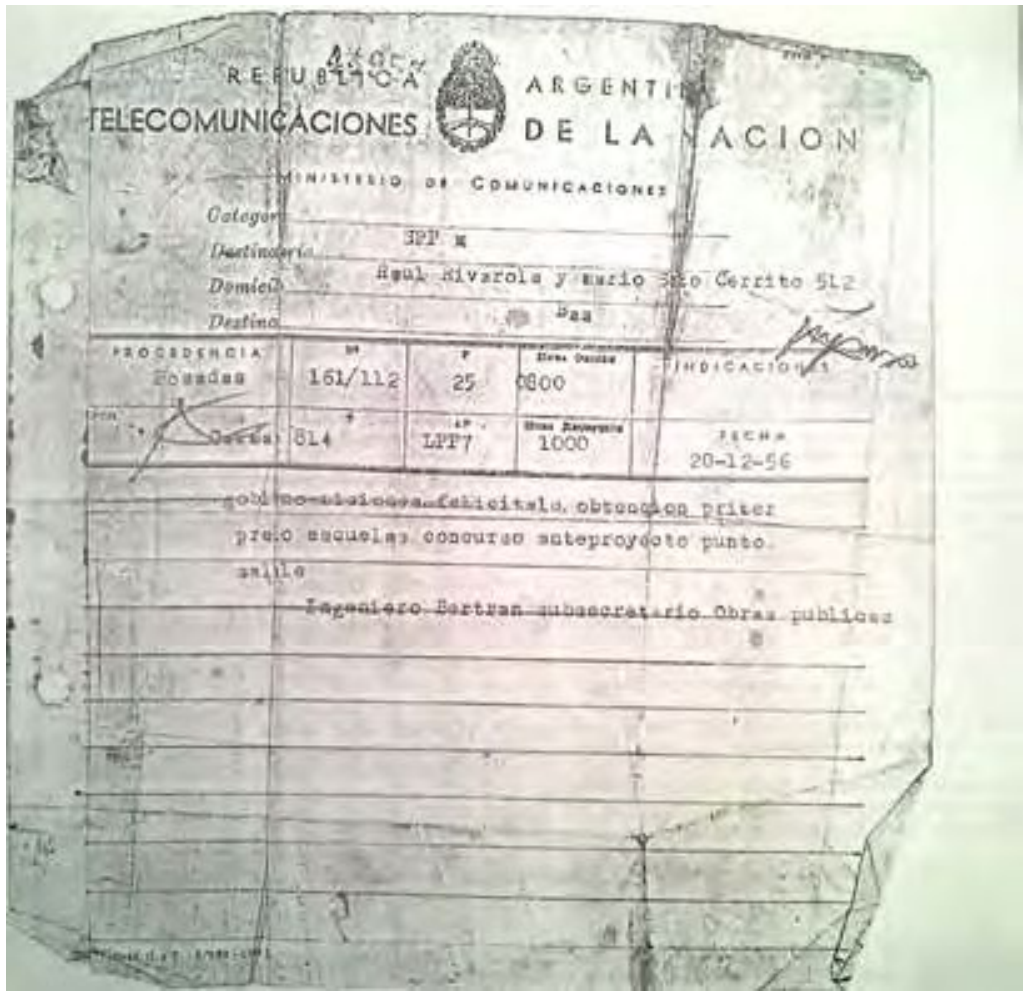


Primer Plan de trabajos Públicos de 1956

Las cuatro escuelas de madera en Misiones

Paneles del concurso
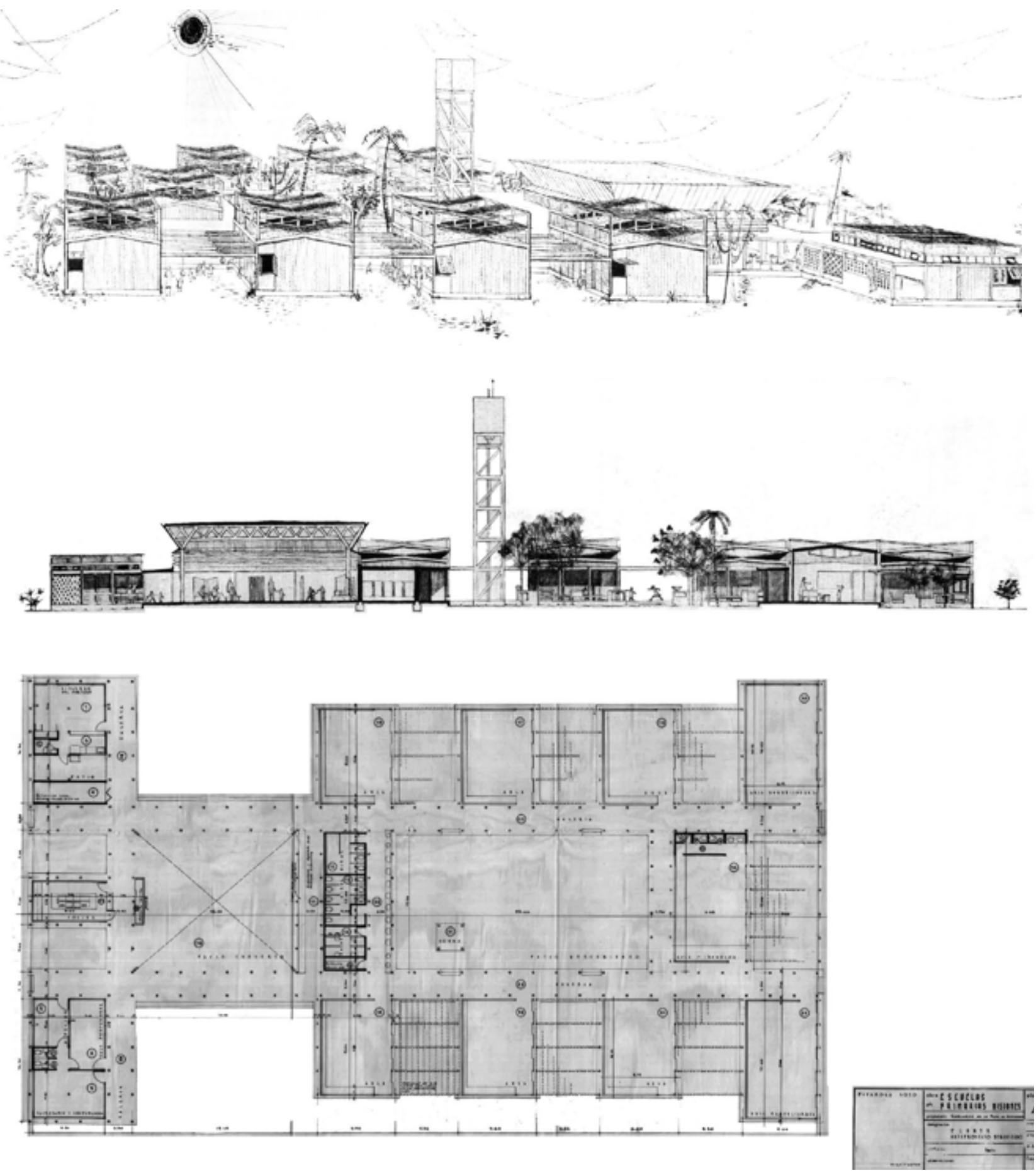

$27-28-29$ 

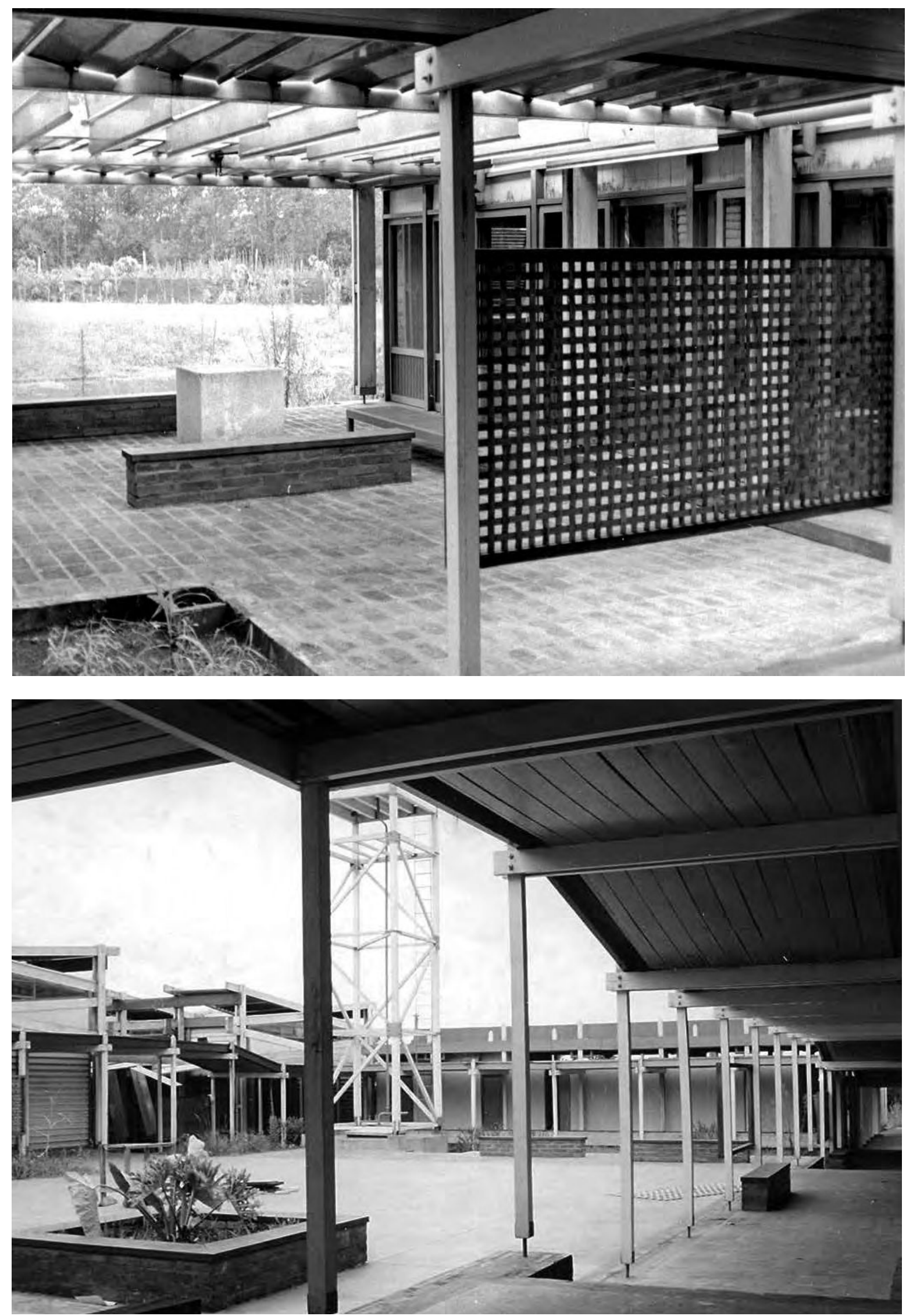

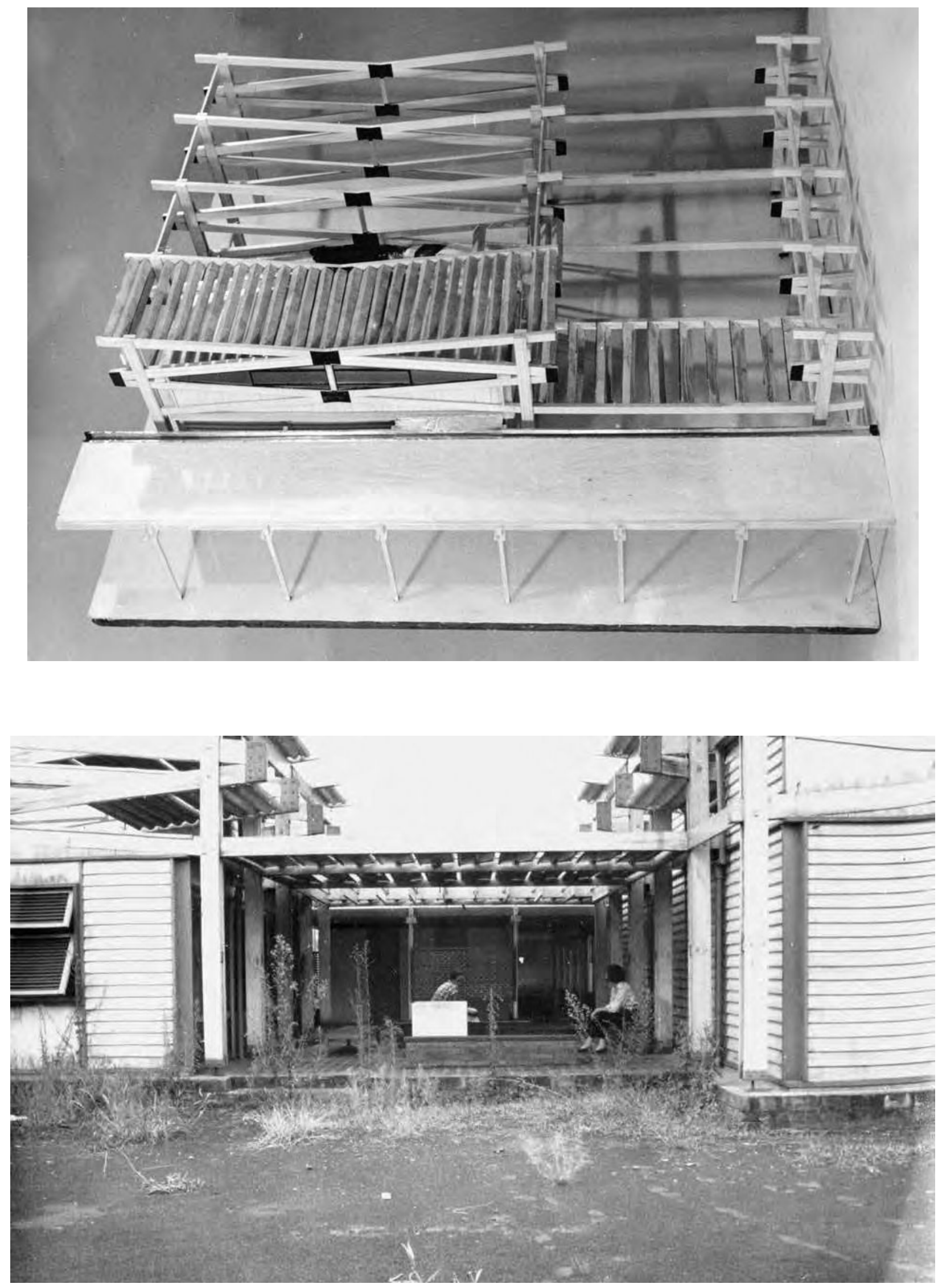

32- 33 
Primer Plan de trabajos Públicos de 1956

Las cuatro escuelas de madera en Misiones

Paneles del concurso
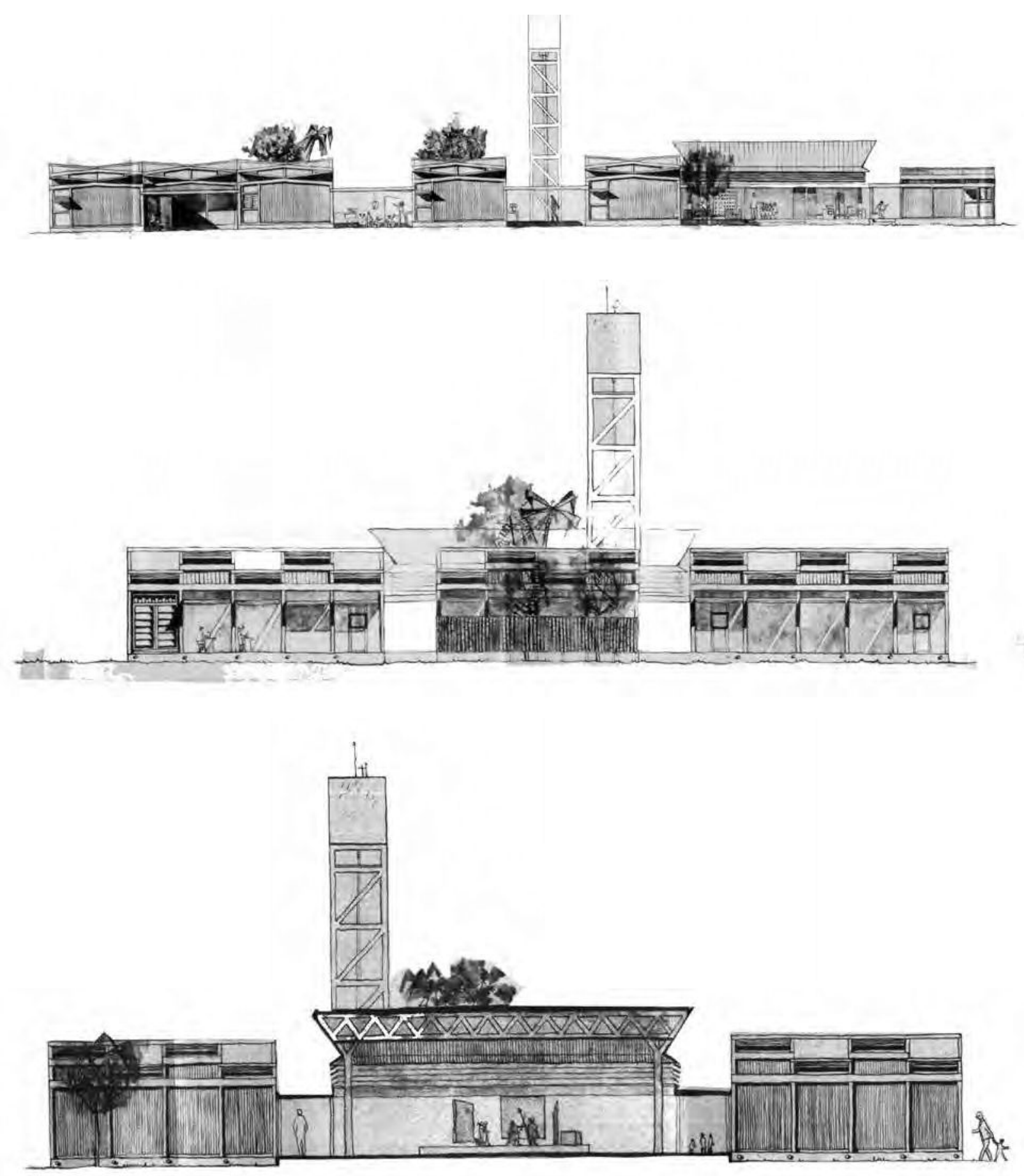

$34-35-36$ 
Primer Plan de trabajos Públicos de 1956

Las cuatro escuelas de madera en Misiones

Legajo de Obra, planos de detalles y cortes críticos
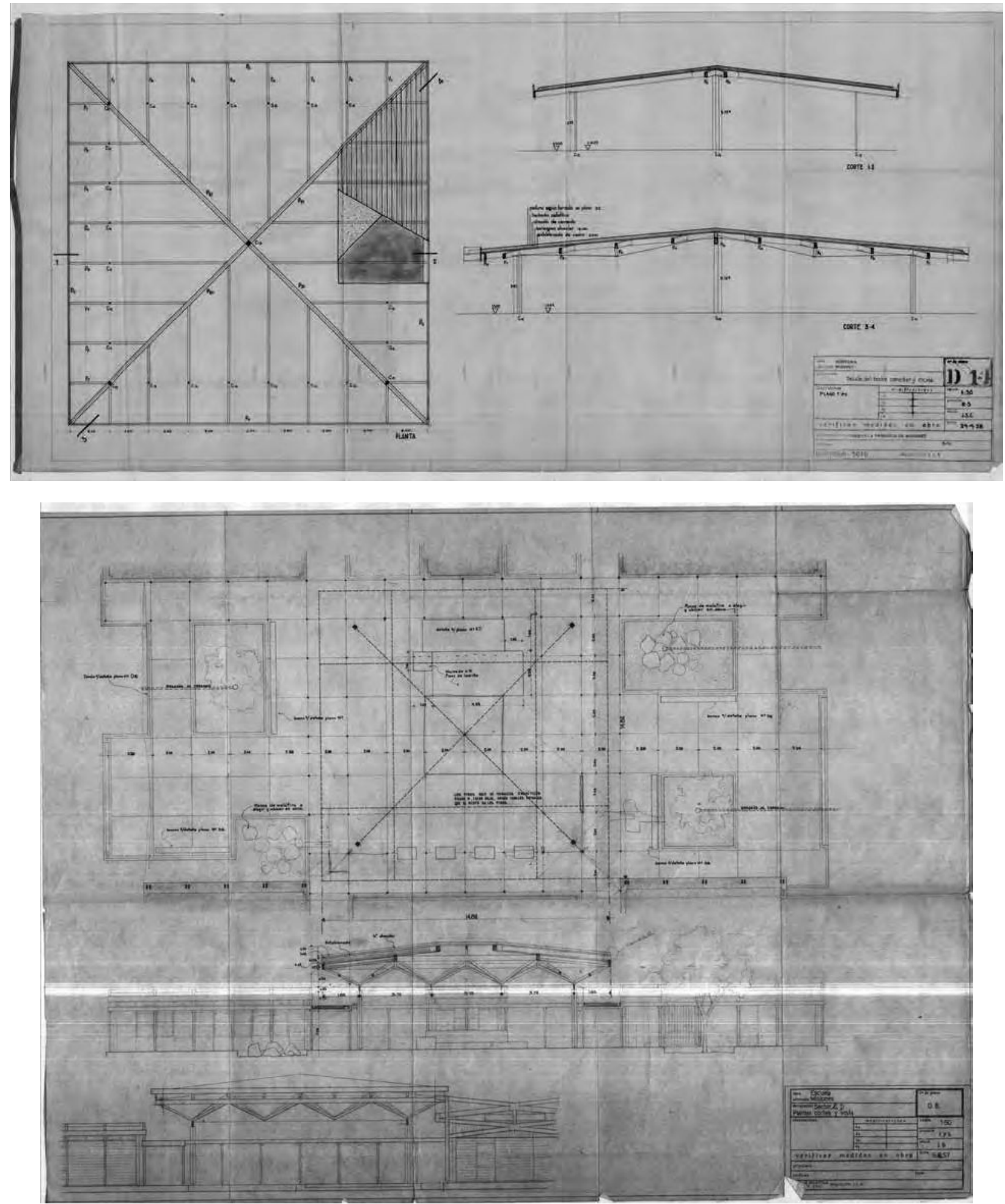

$37-38$ 

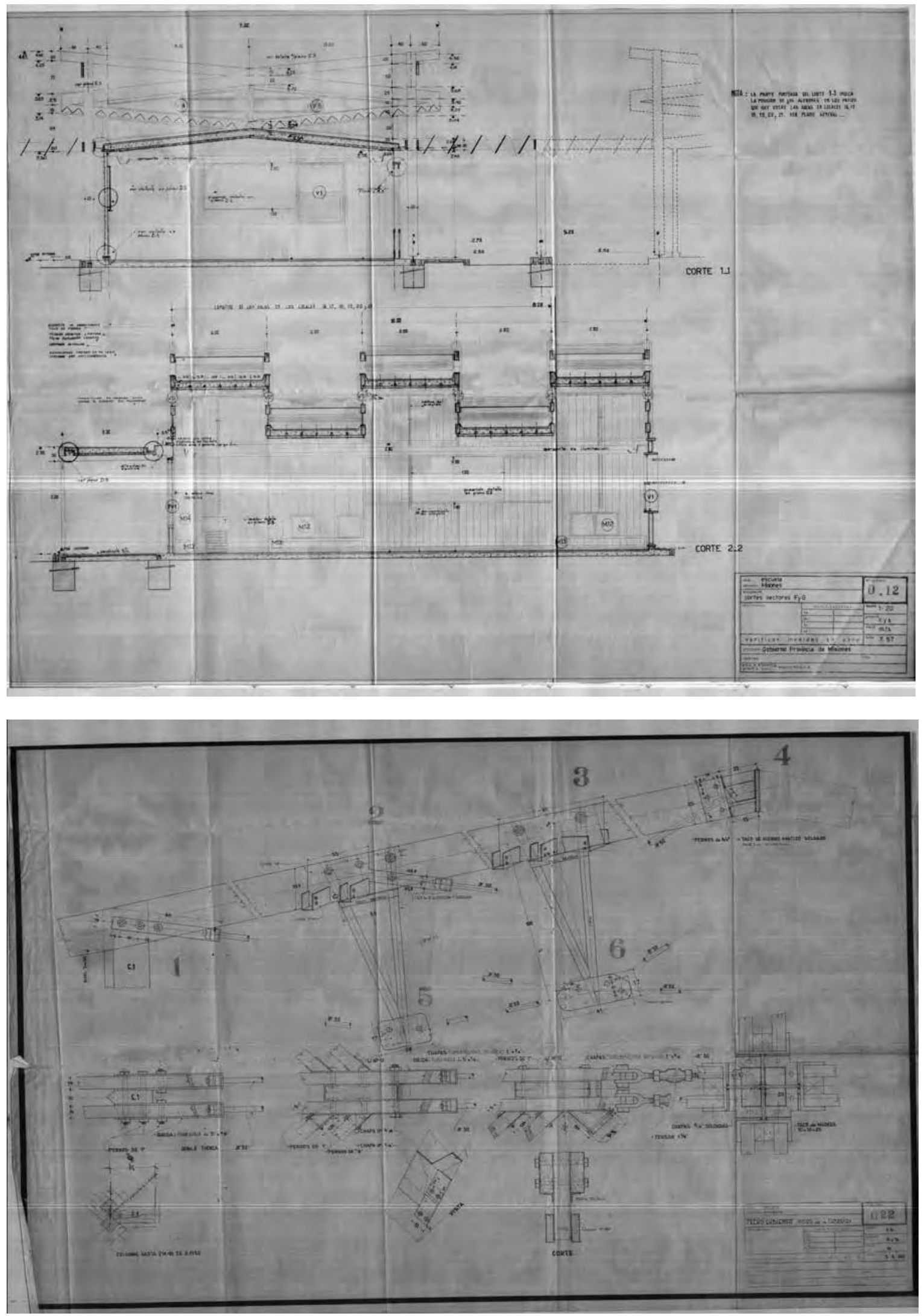

$39-40$ 

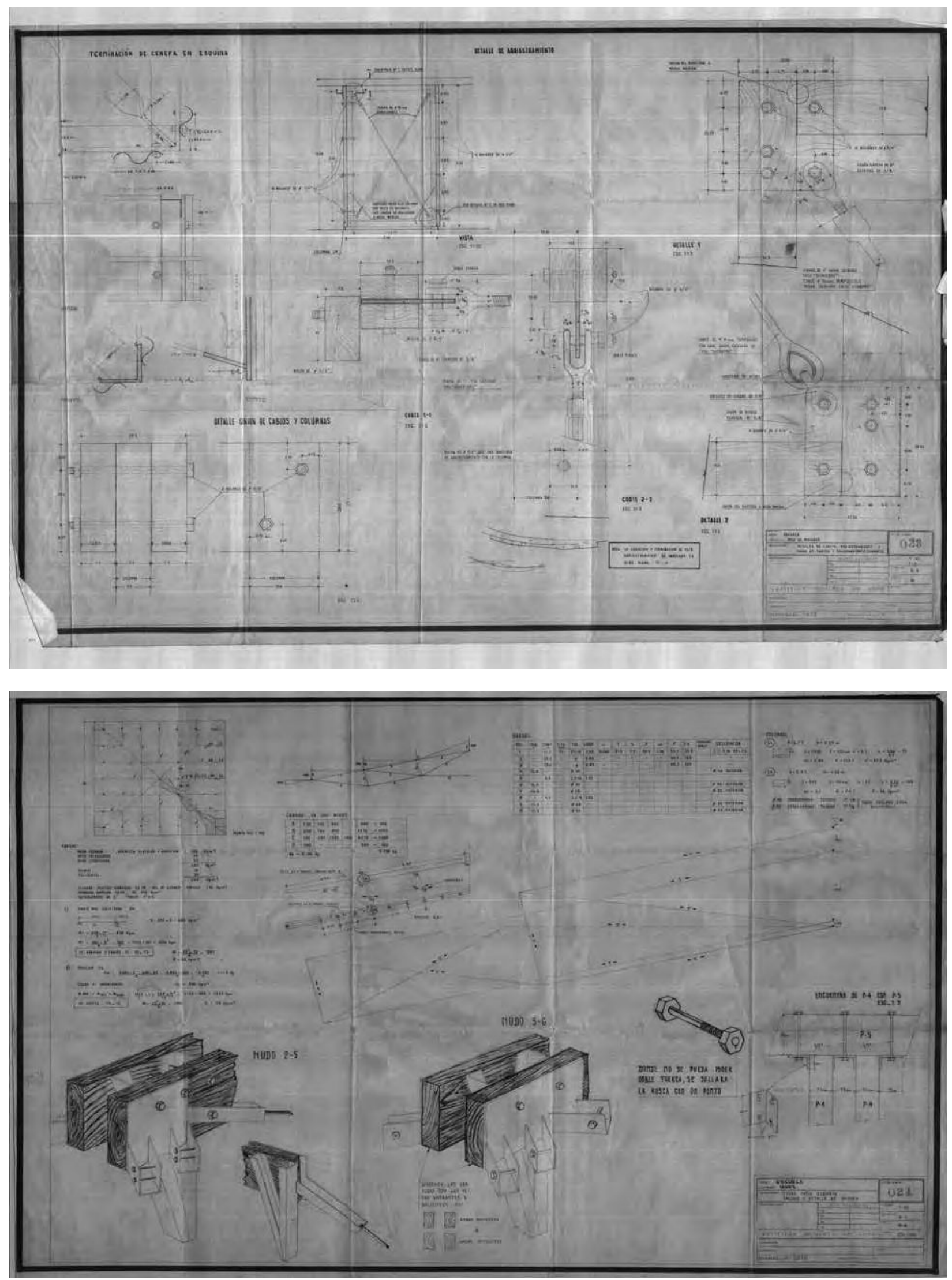

$41-42$ 

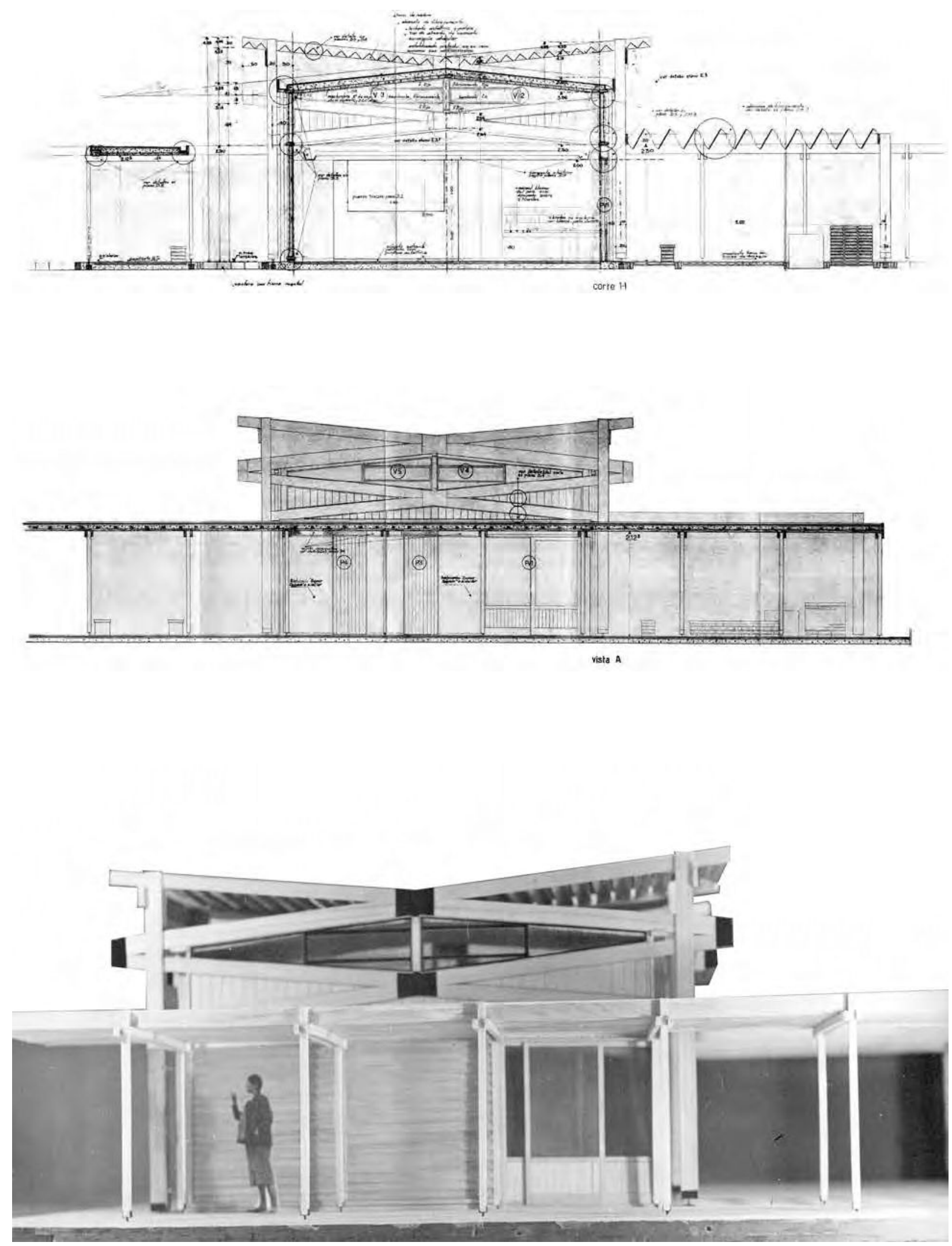

$43-44-45$ 

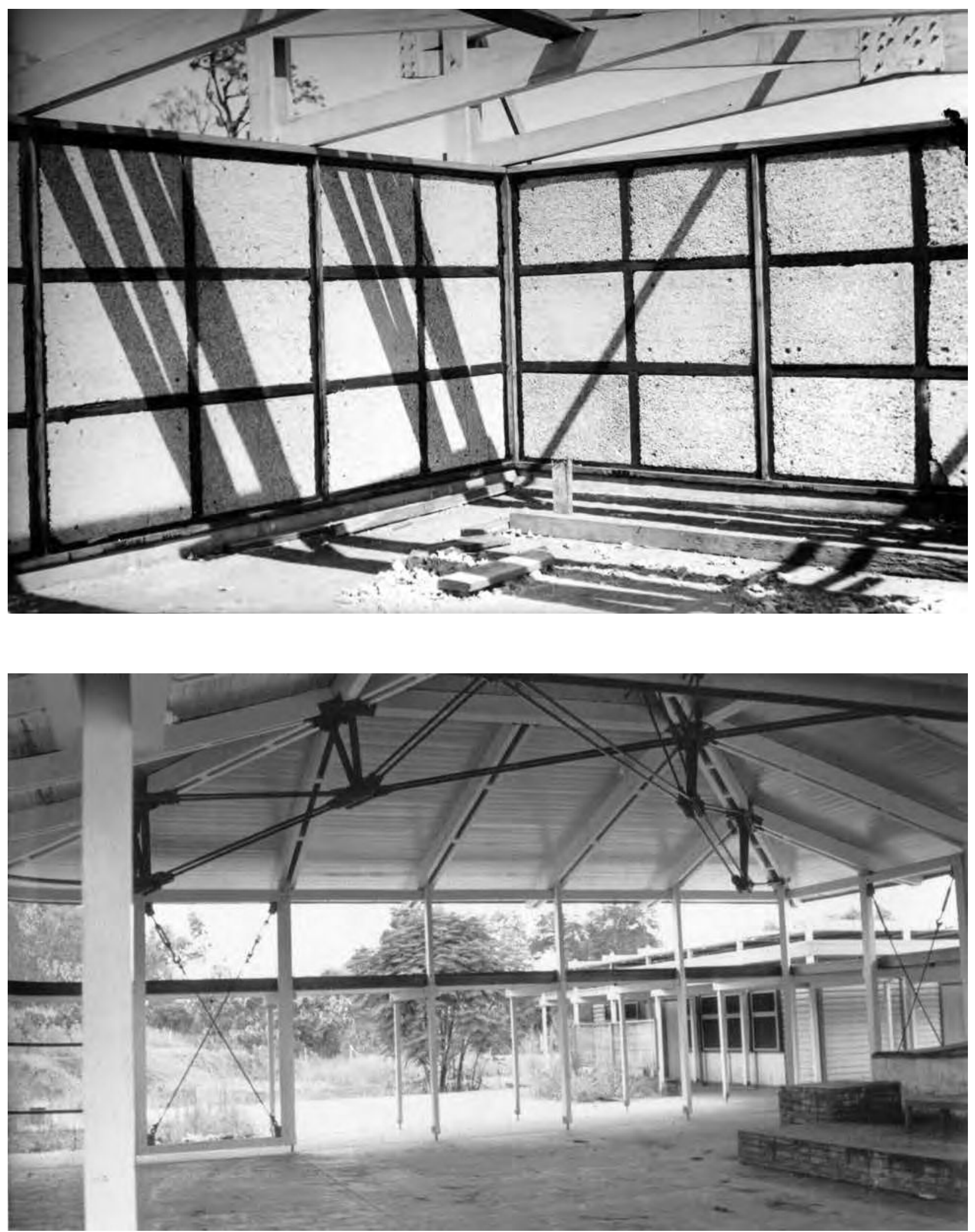

46- 47 


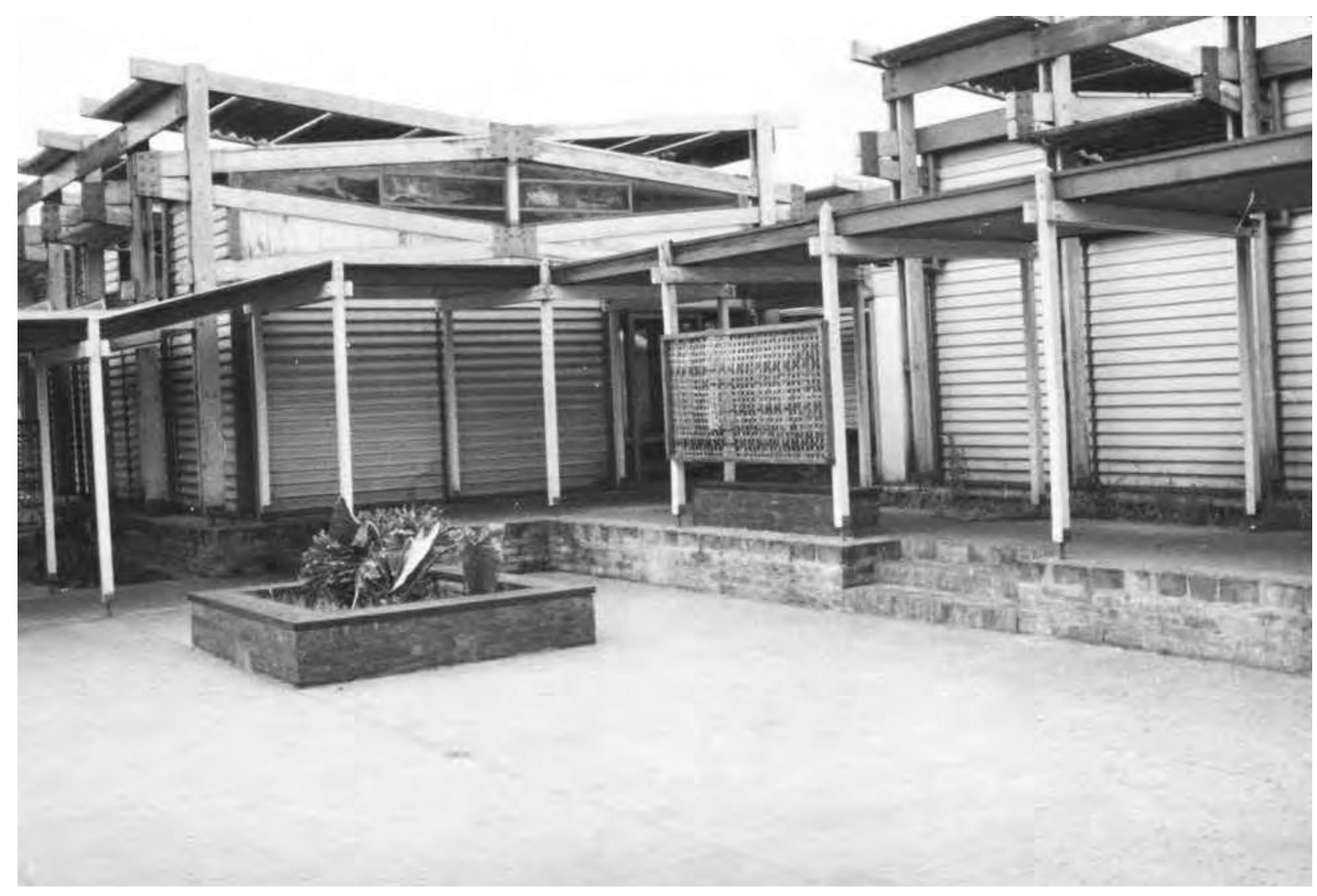

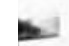

(1)

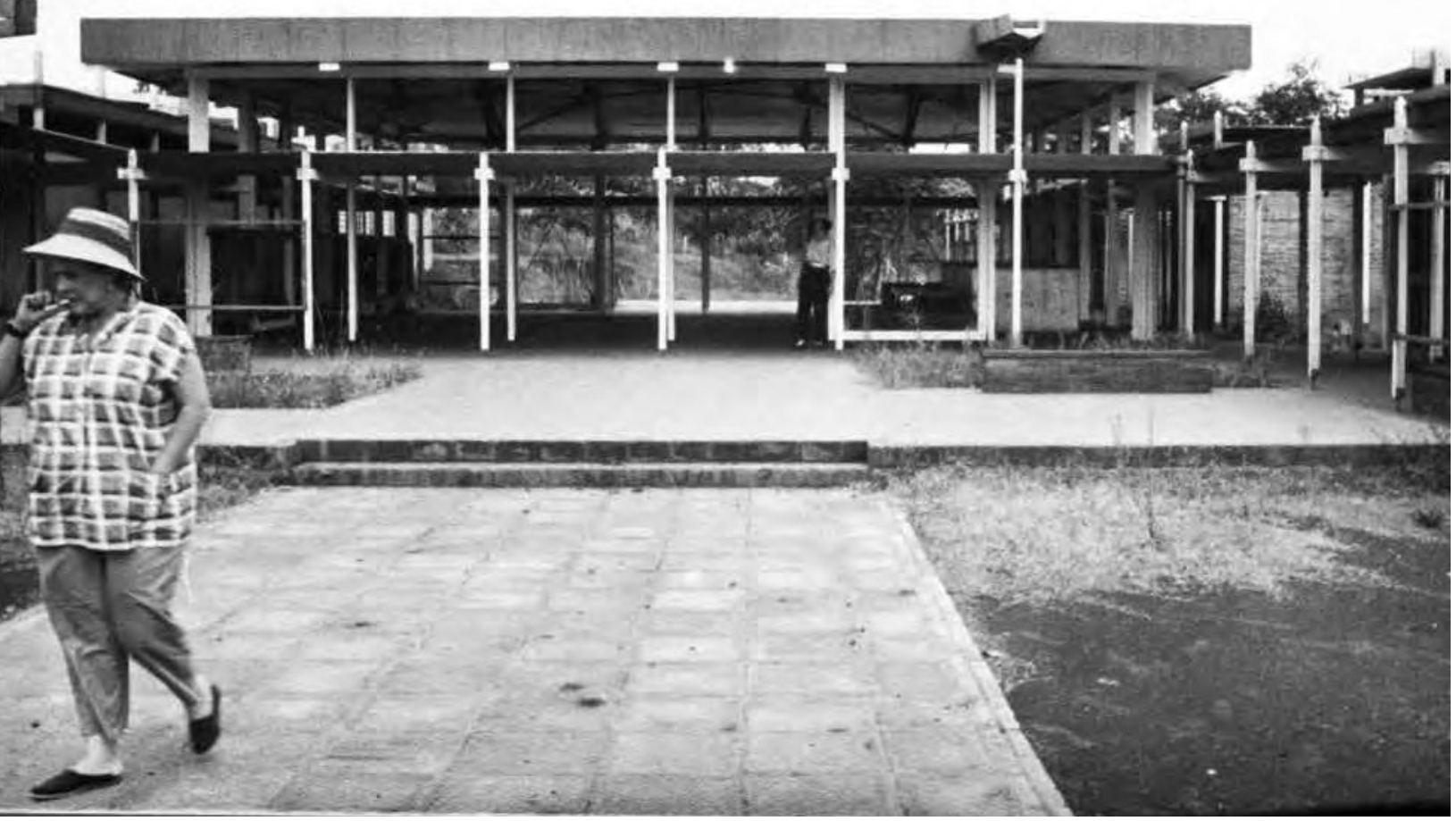

$48-49$ 
Primer Plan de trabajos Públicos de 1956

Legajo de Obra, planos de detalles, estudio de iluminación y fotos de maqueta
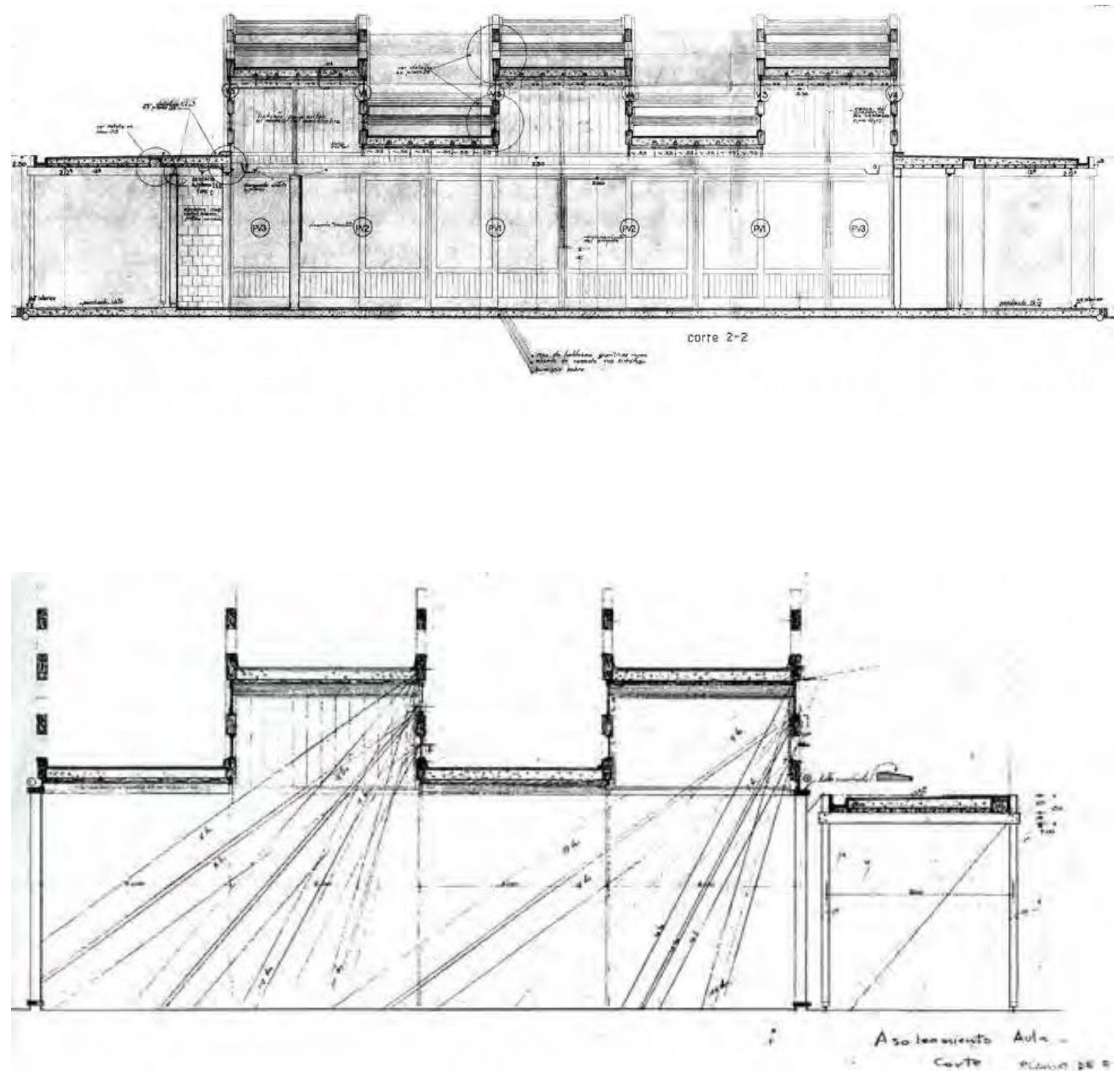

50- 51 

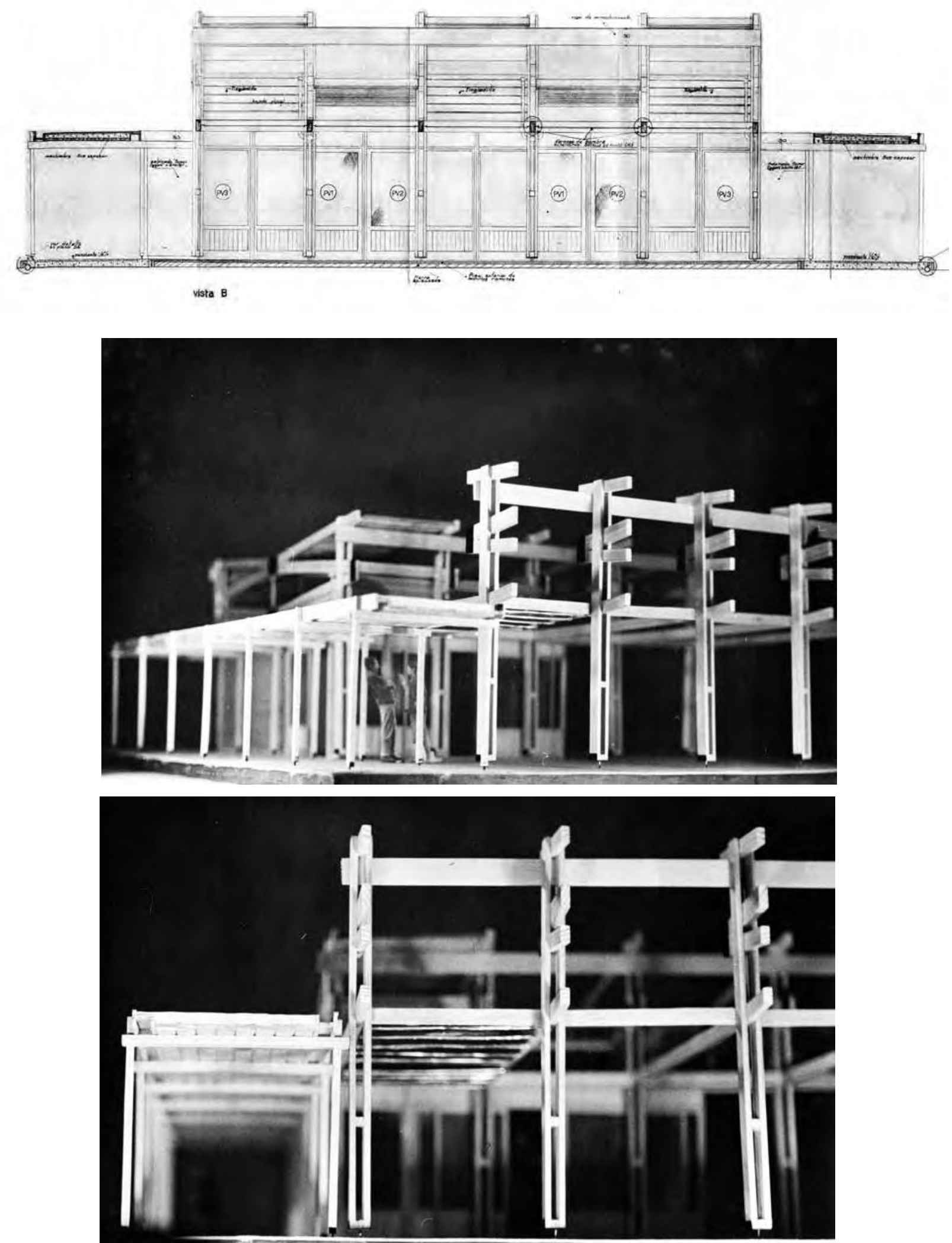

$52-53-54$ 


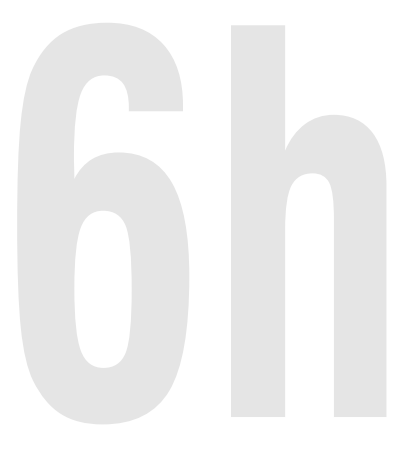

SEIS HOSTERÍAS DE MADERA EN LA PROVINCIA DE MISIONES

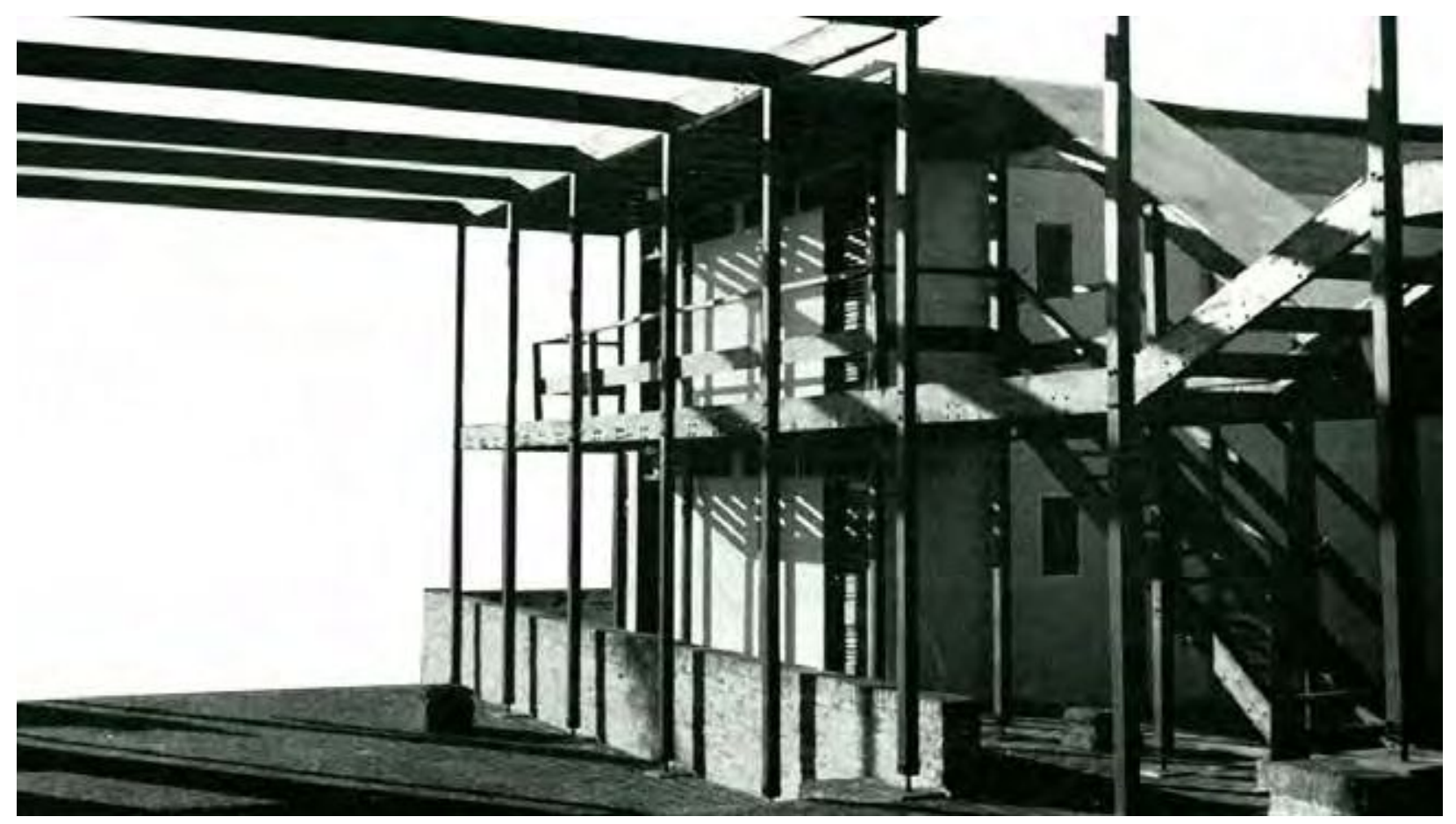




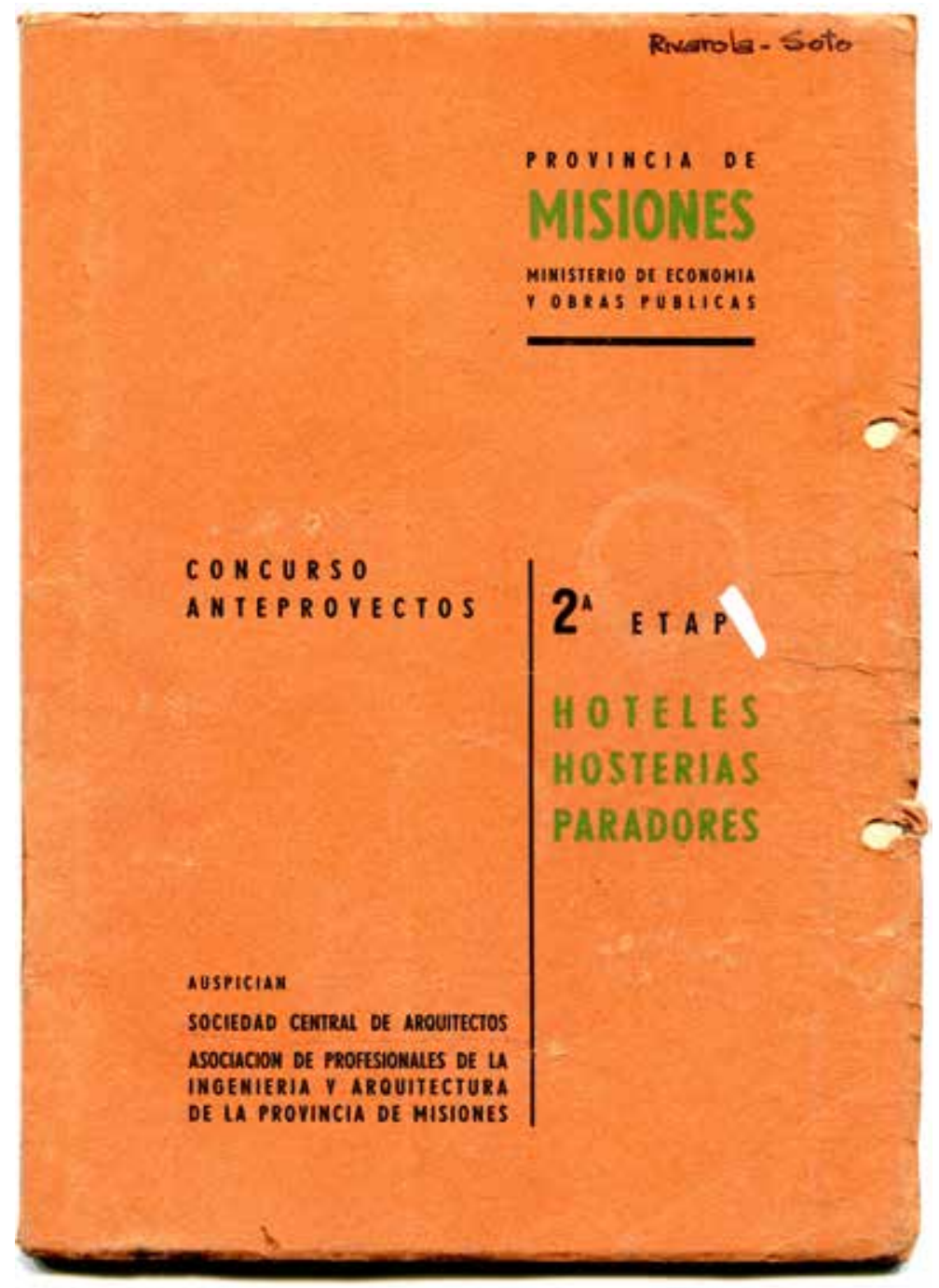


Segundo Plan de trabajos Públicos de 1957

Seis Hosterías de madera en Misiones

Pliego del llamado a concurso e implementación de la Segunda Etapa de Trabajos
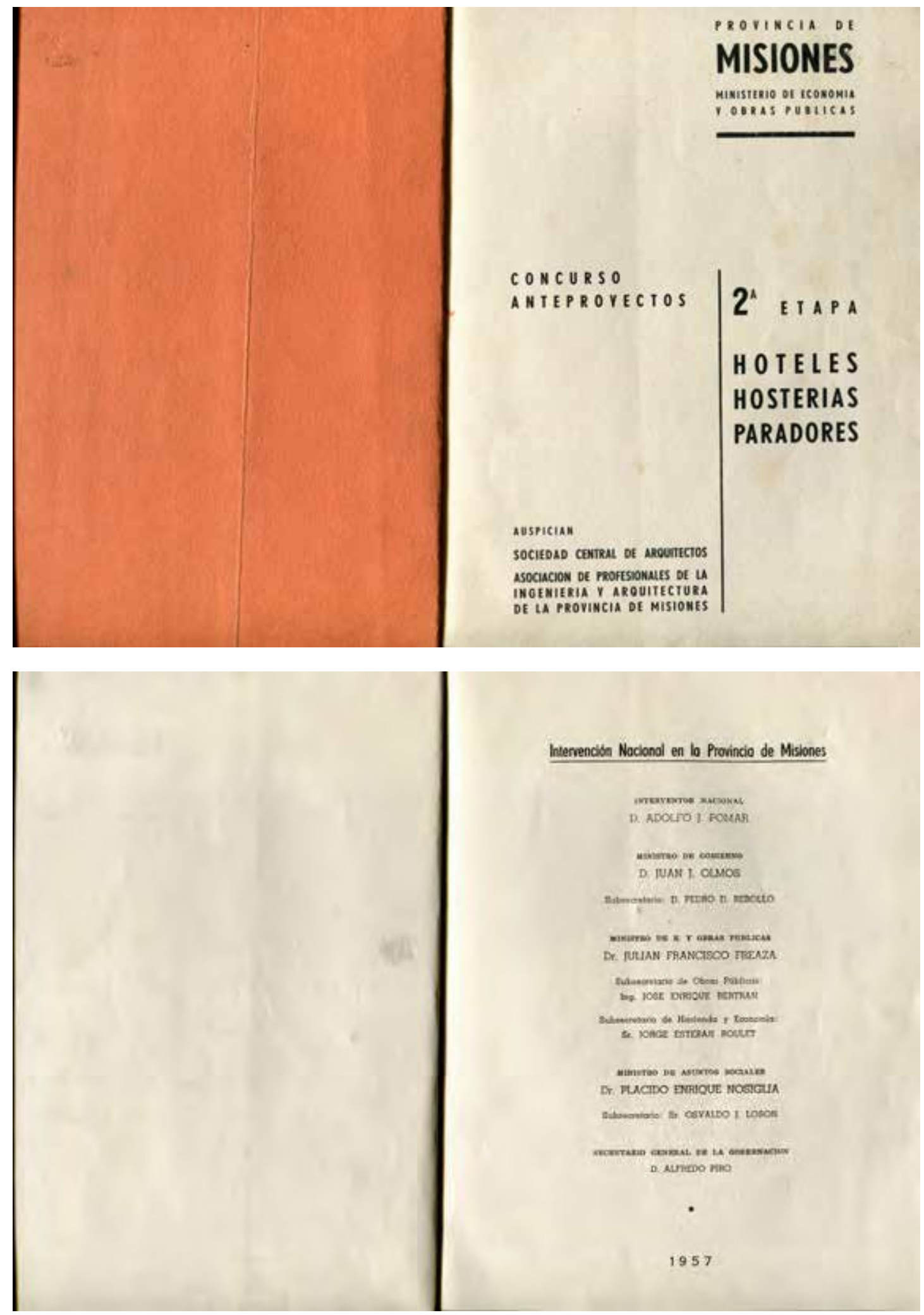

$56-57$ 


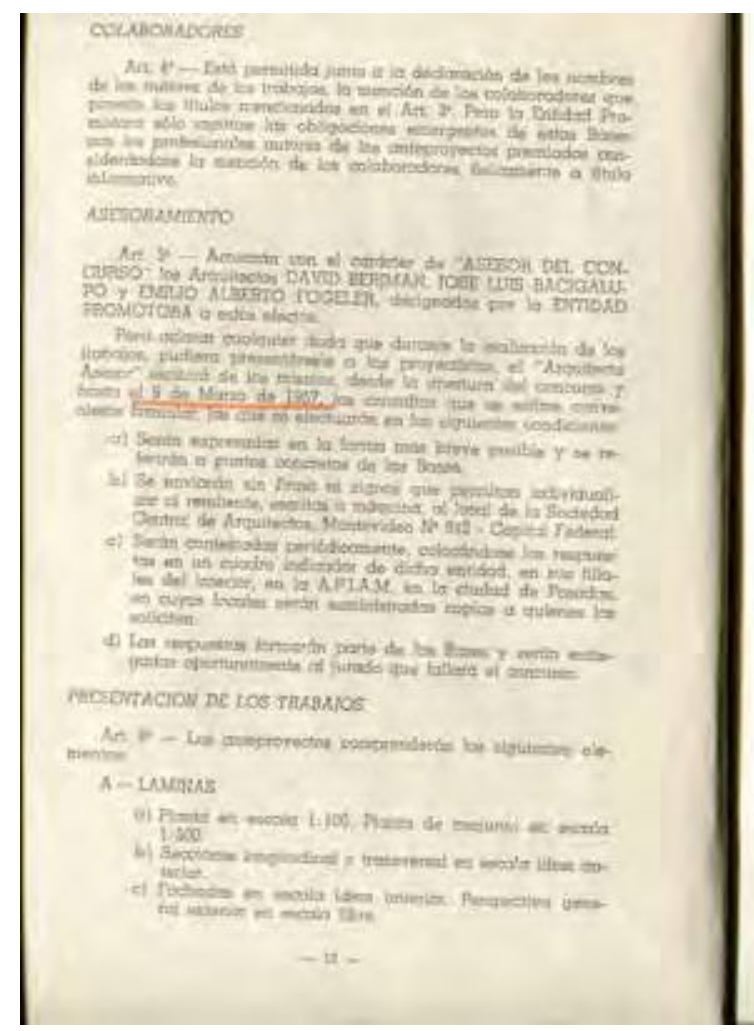

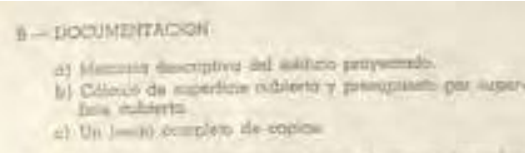

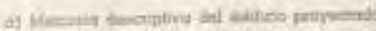

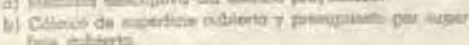

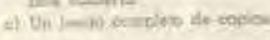

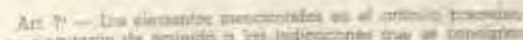

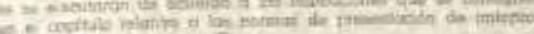

Ces on in

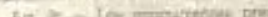

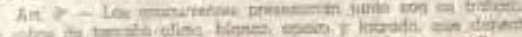
$=-10$.

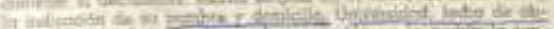

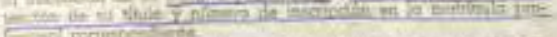

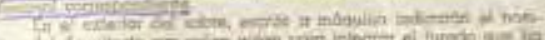

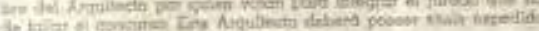

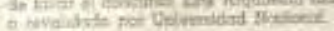

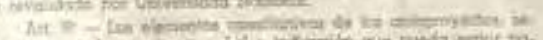

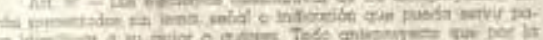

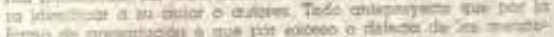

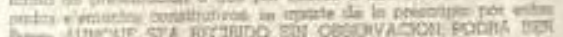

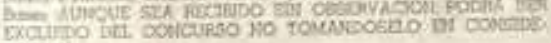
Thetow

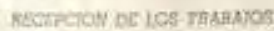

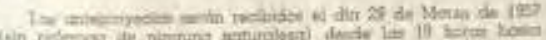

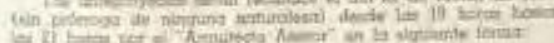

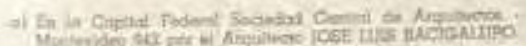

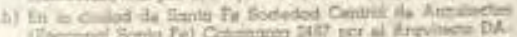

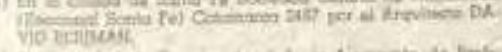

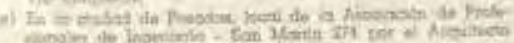

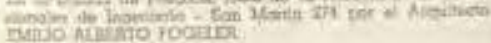

- if-

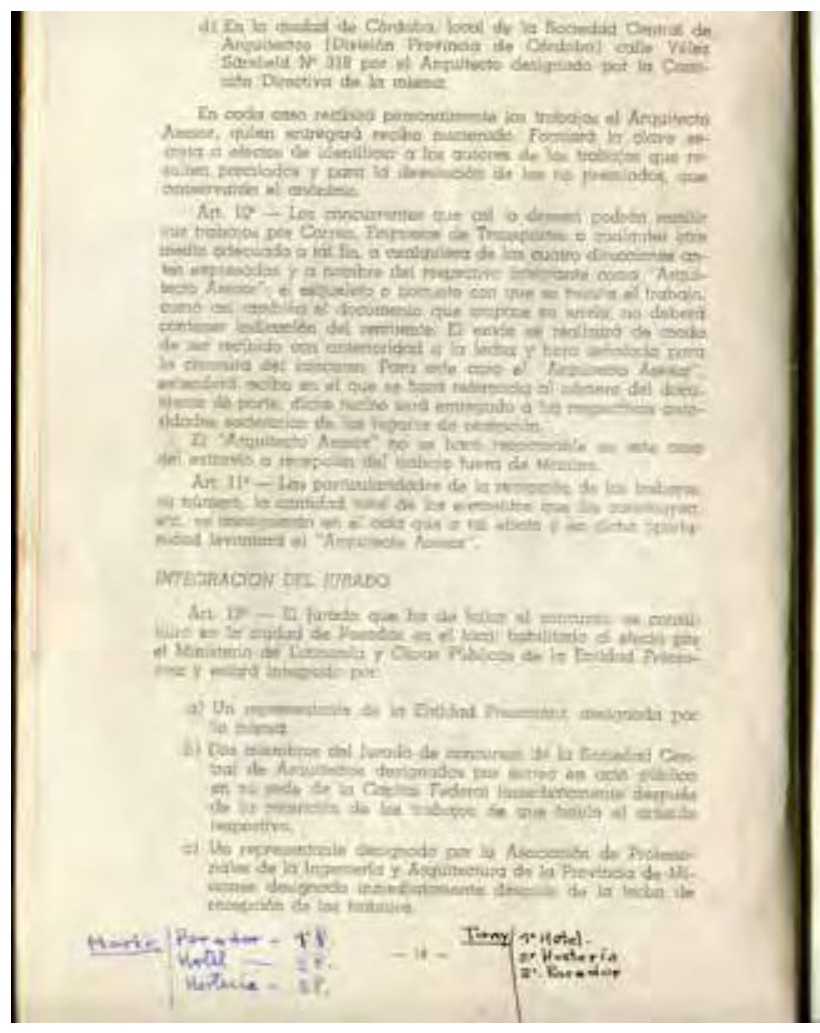

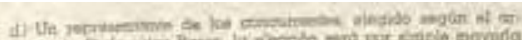

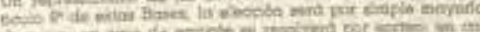

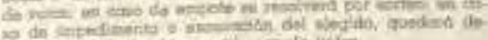

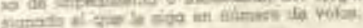

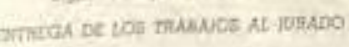

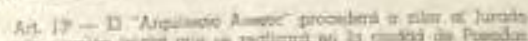

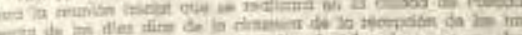

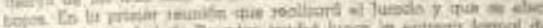

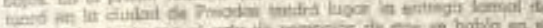

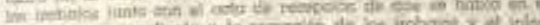

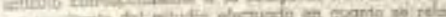

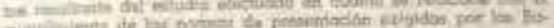

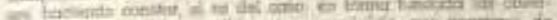

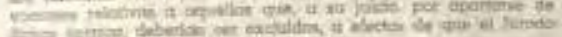

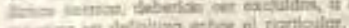

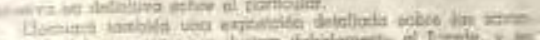

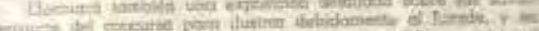

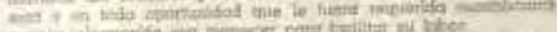

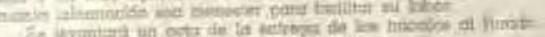

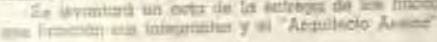

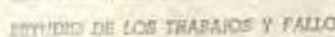

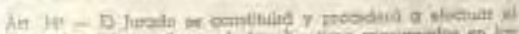

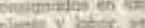
$=$ man

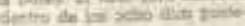

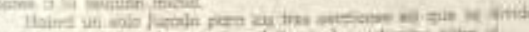

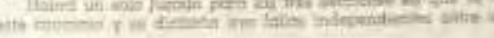
inewo⿰氵

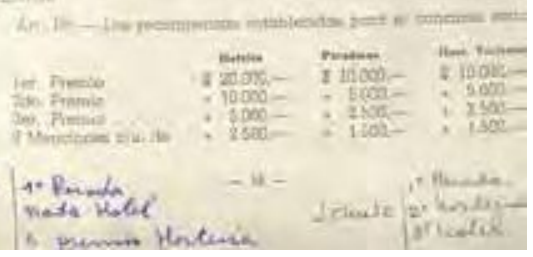

$58-59$ 


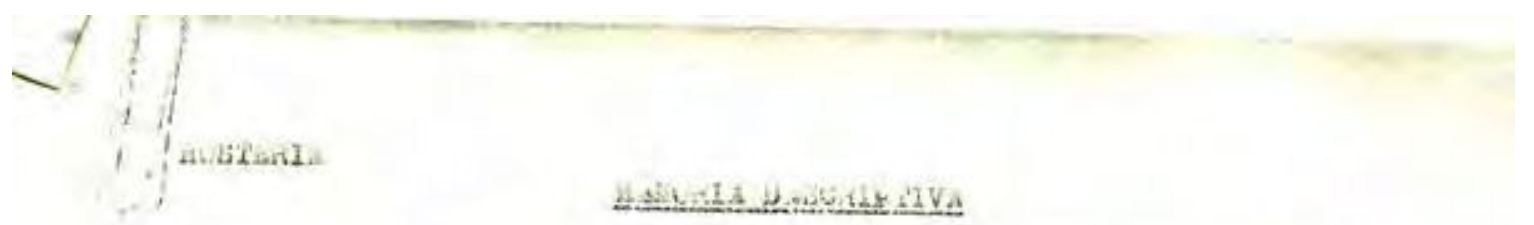

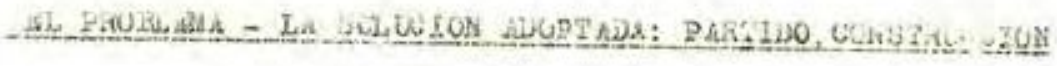

\section{E2. Prob?}

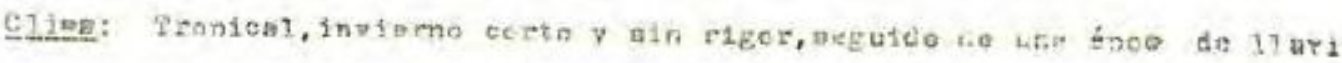

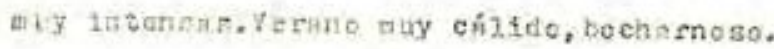

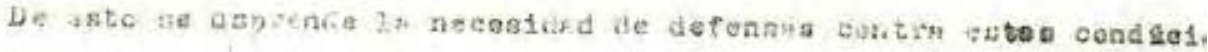

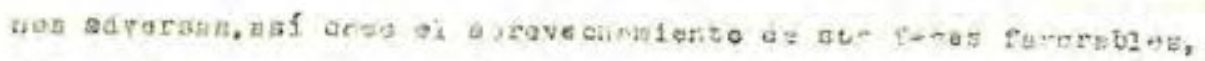

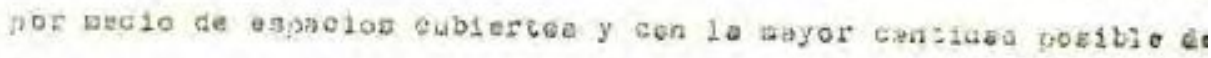

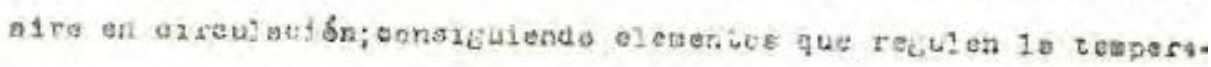

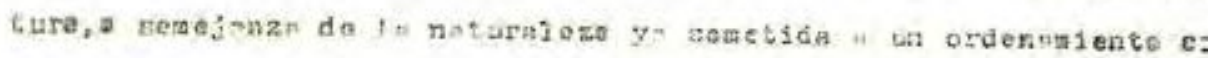

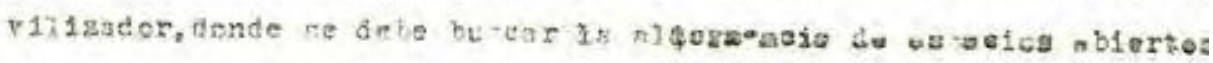

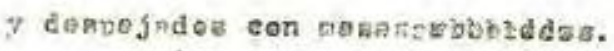

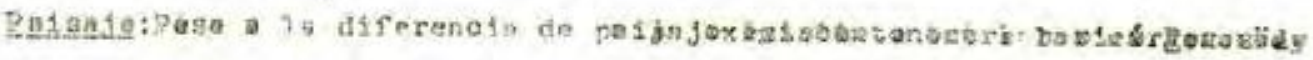

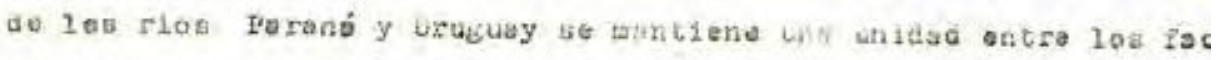

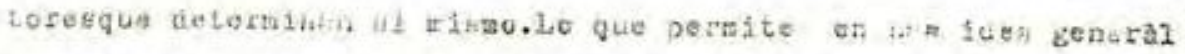

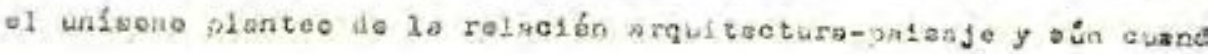

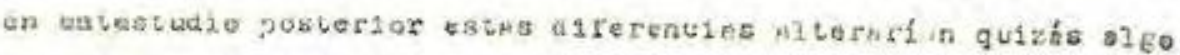

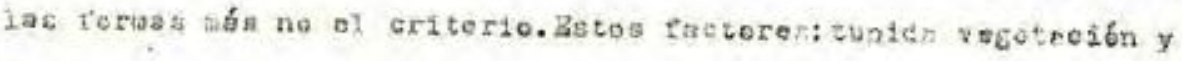

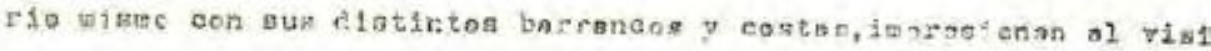

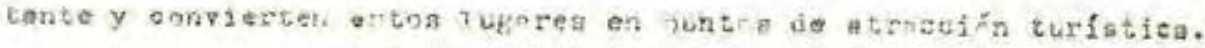

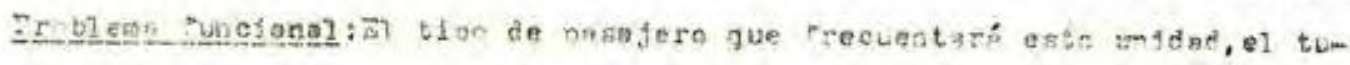

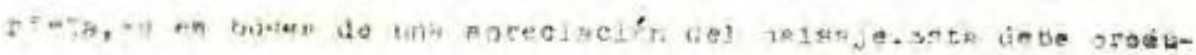

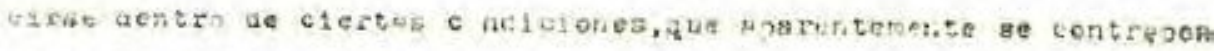

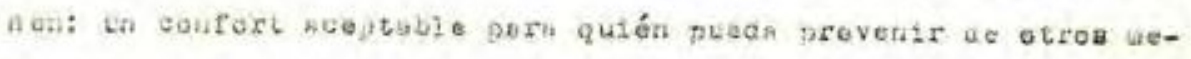

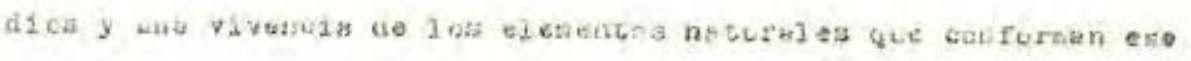
nothase.

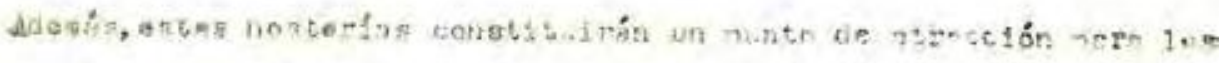

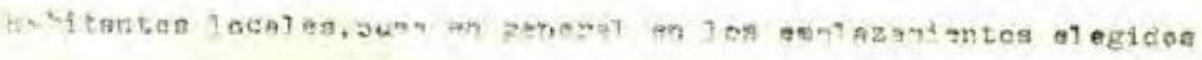




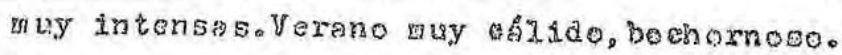

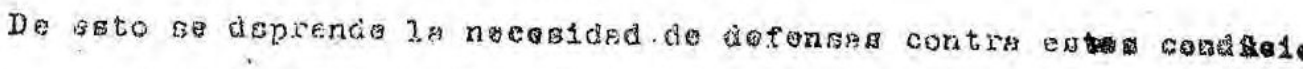

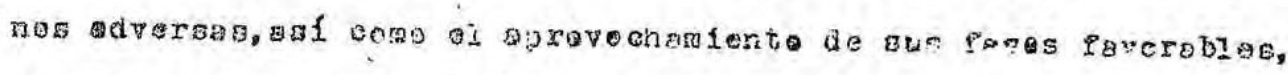

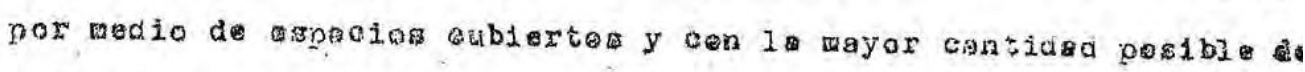

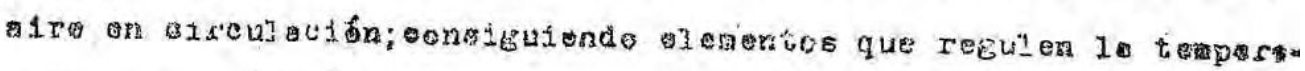

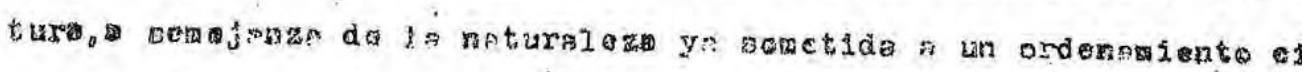

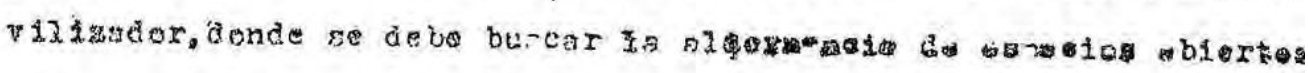

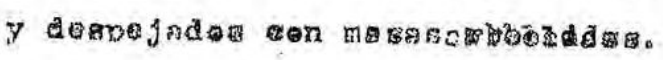

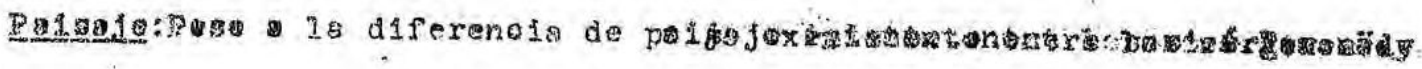

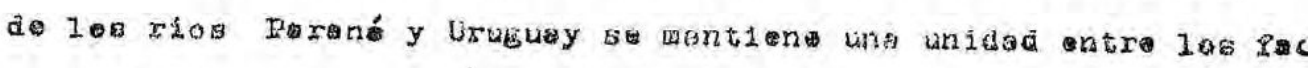

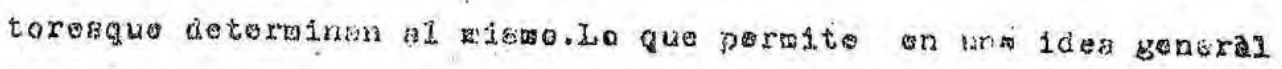

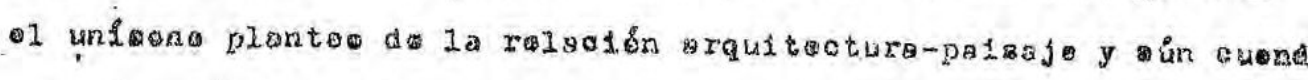

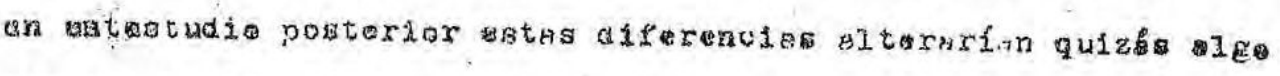

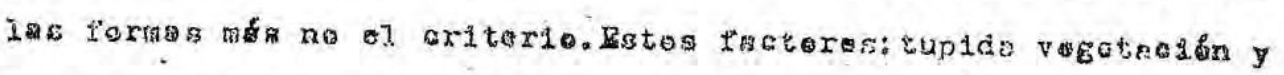

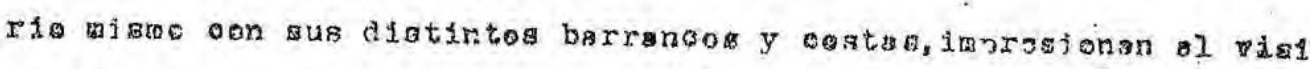

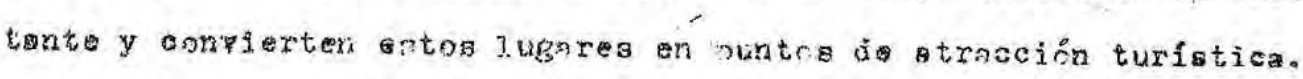

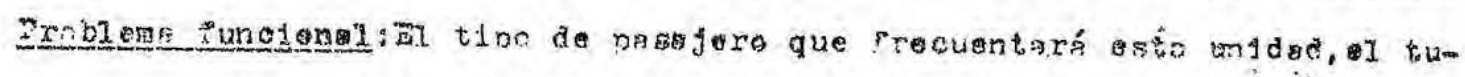

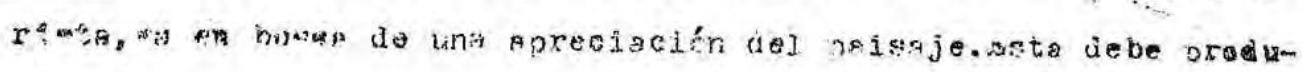

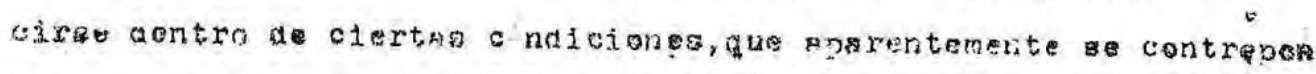
non: un confort aceptable para quién pusda provenif de otros ae-

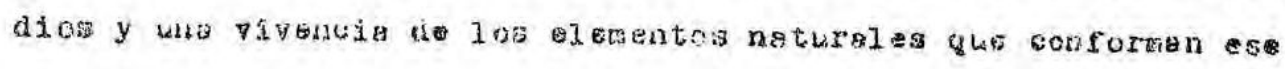

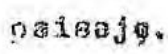

4dato

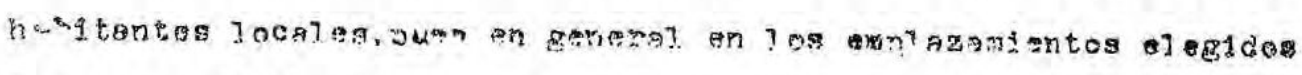

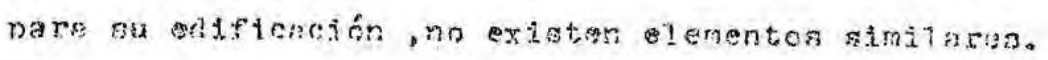

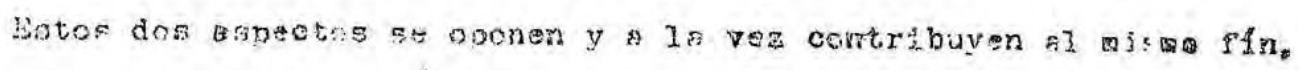

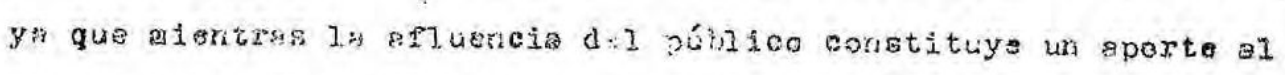

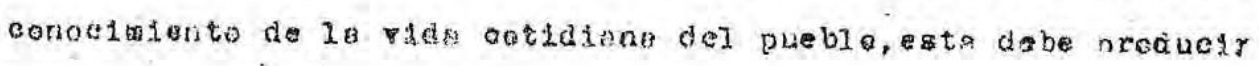

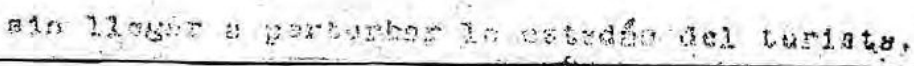




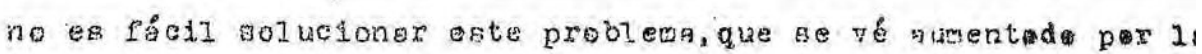
difloultados suscltadas por ol scarroo.

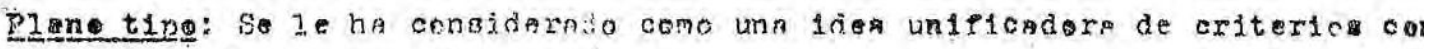
ceptualeg, funciniala y conftructivos, pero sin qua so contitu: or Lns solución rígida que ne nemita la sduntación la vorion

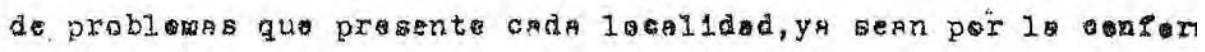
clón del tecreno, ublagelón, pondientes, +ote.

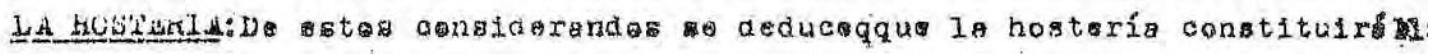

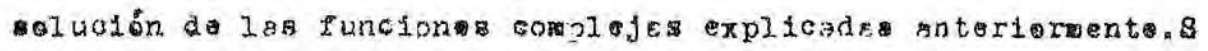

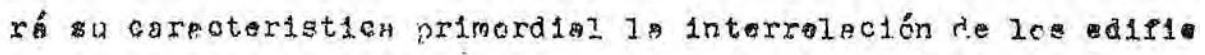
y I. nature Iex

\section{Le Belución siontand}

U Jos elementos de jusejo brindadon por oj onílisio del probl.

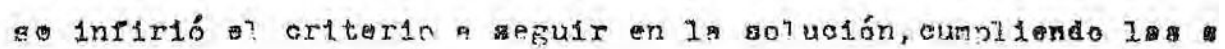
guitentes condicionas:

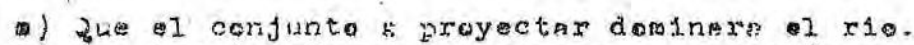

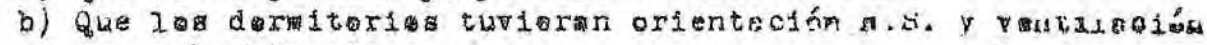
a abors ipenten

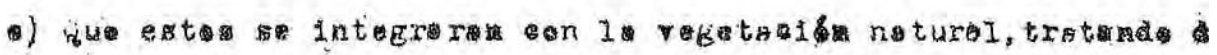
xespetarsala en todo 10 posible.

a) Que Ia wone ala que acude I nibrico: eanchas de Jug

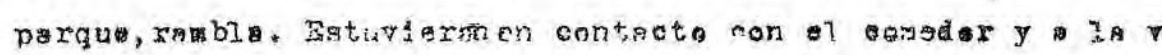
Puesen dominades deste loo cermitorios ya quo so comadera aqualjo日 orementor come porte integrante del paiano.

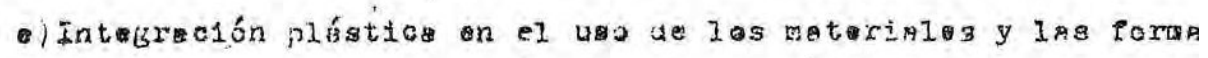
con In natuxalozs.

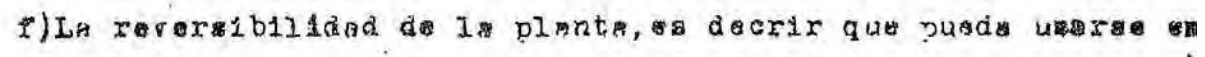
J.e rírectes de embos riog.

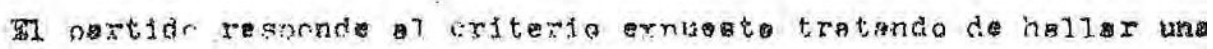

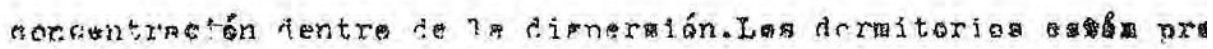

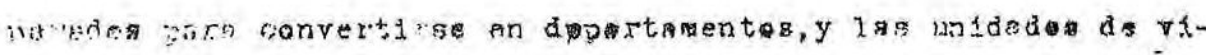

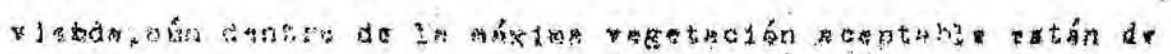


Segundo Plan de trabajos Públicos de 1957

Perspectiva original del concurso realizada por Jorge de la Vega. Foto Hostería San Javier
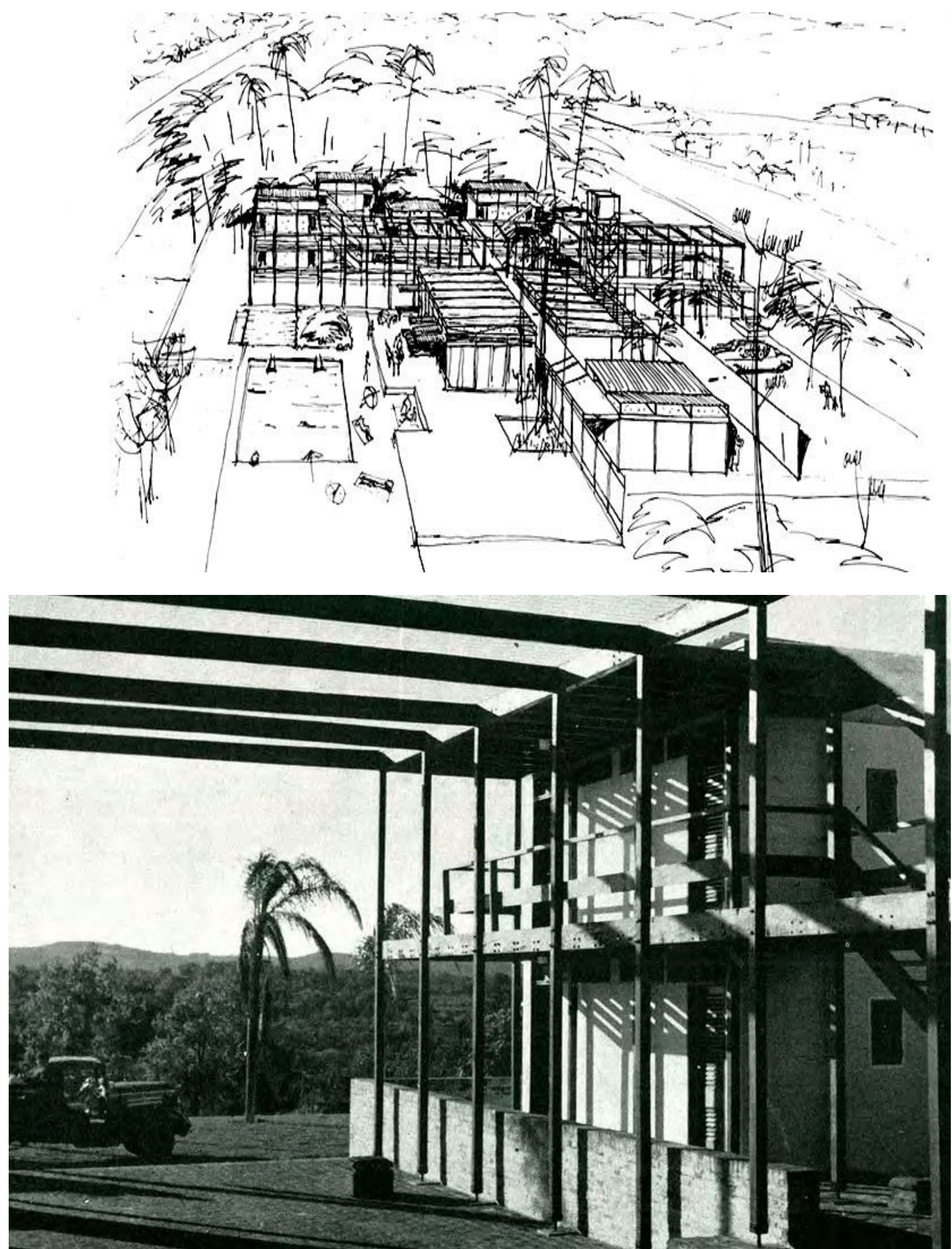

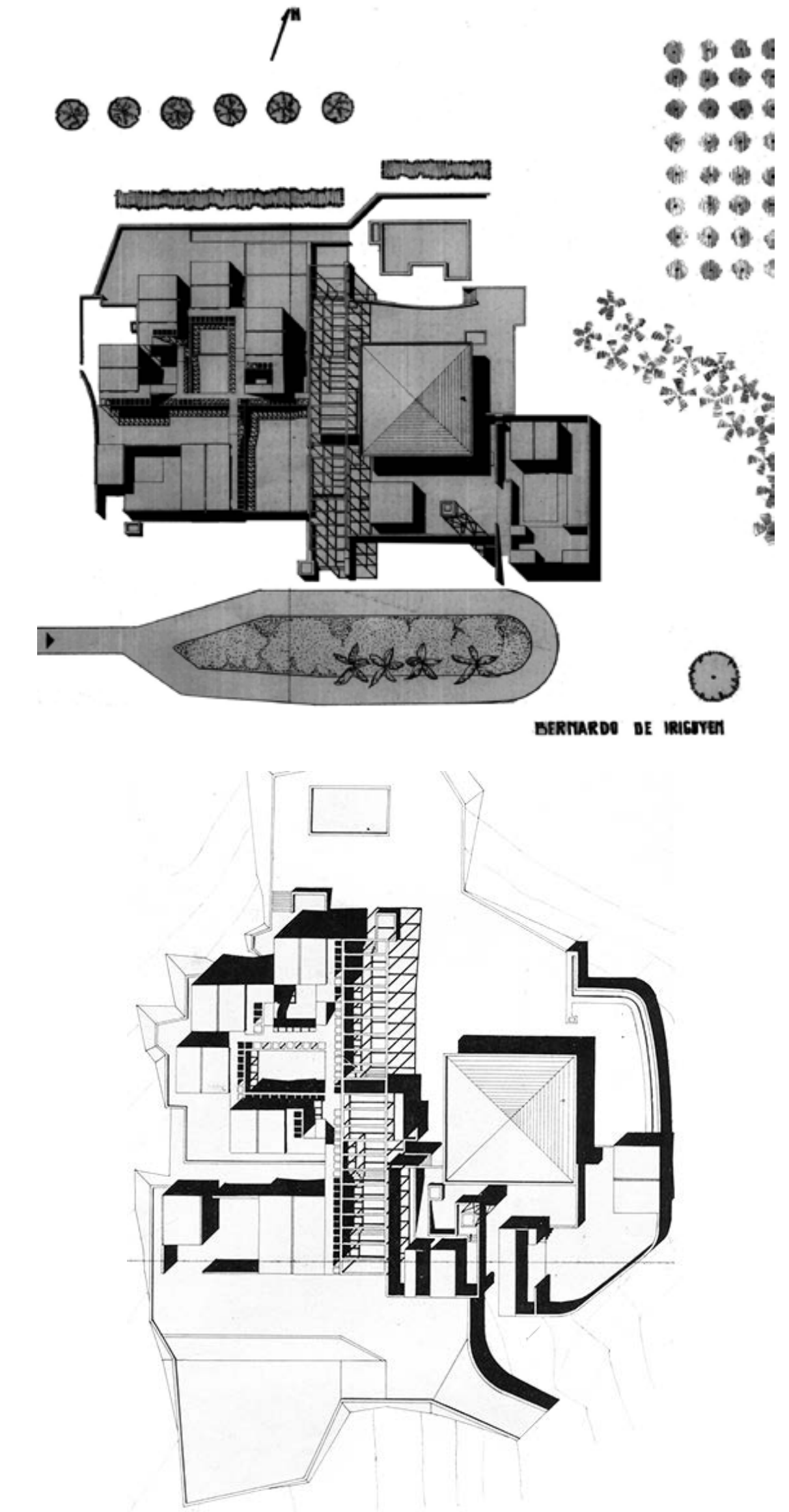

$65-66$ 
Segundo Plan de trabajos Públicos de 1957

Planta de implantación con sombras de las distintas Hosterías
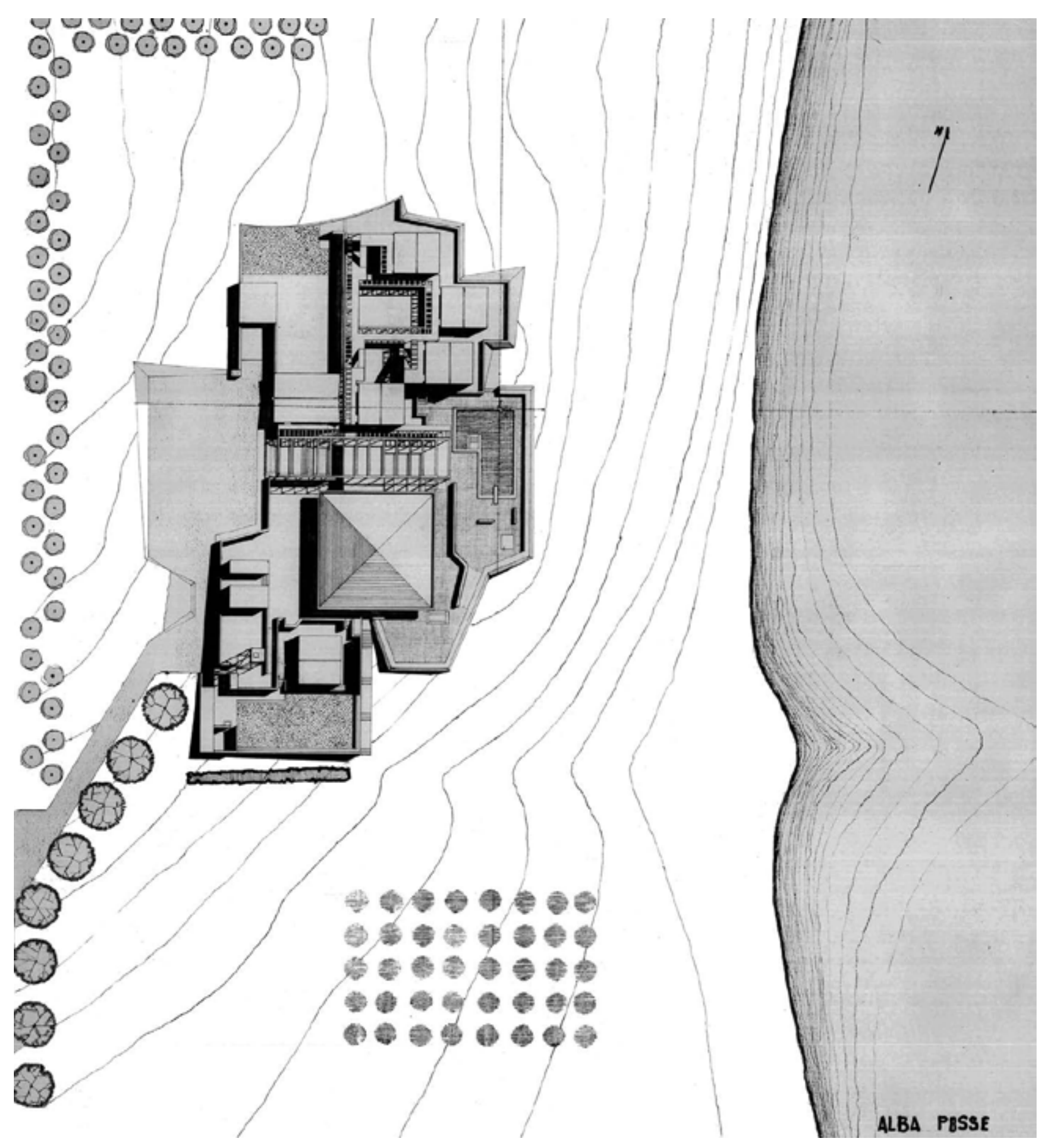

$67-68-69$ 

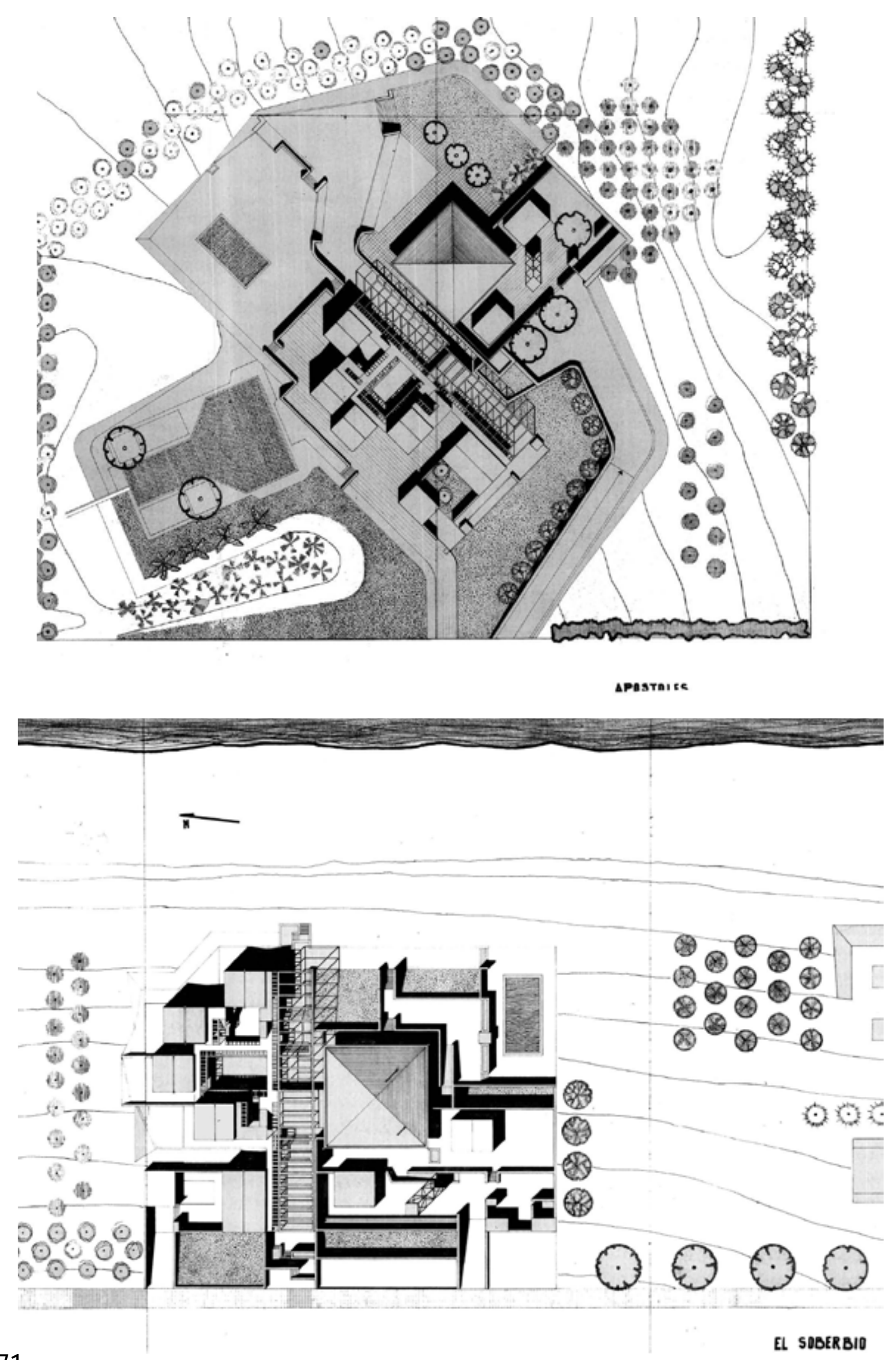

70- 71 
Segundo Plan de trabajos Públicos de 1957

Diseño del mobiliario y fotografía de la Hostería San Javier
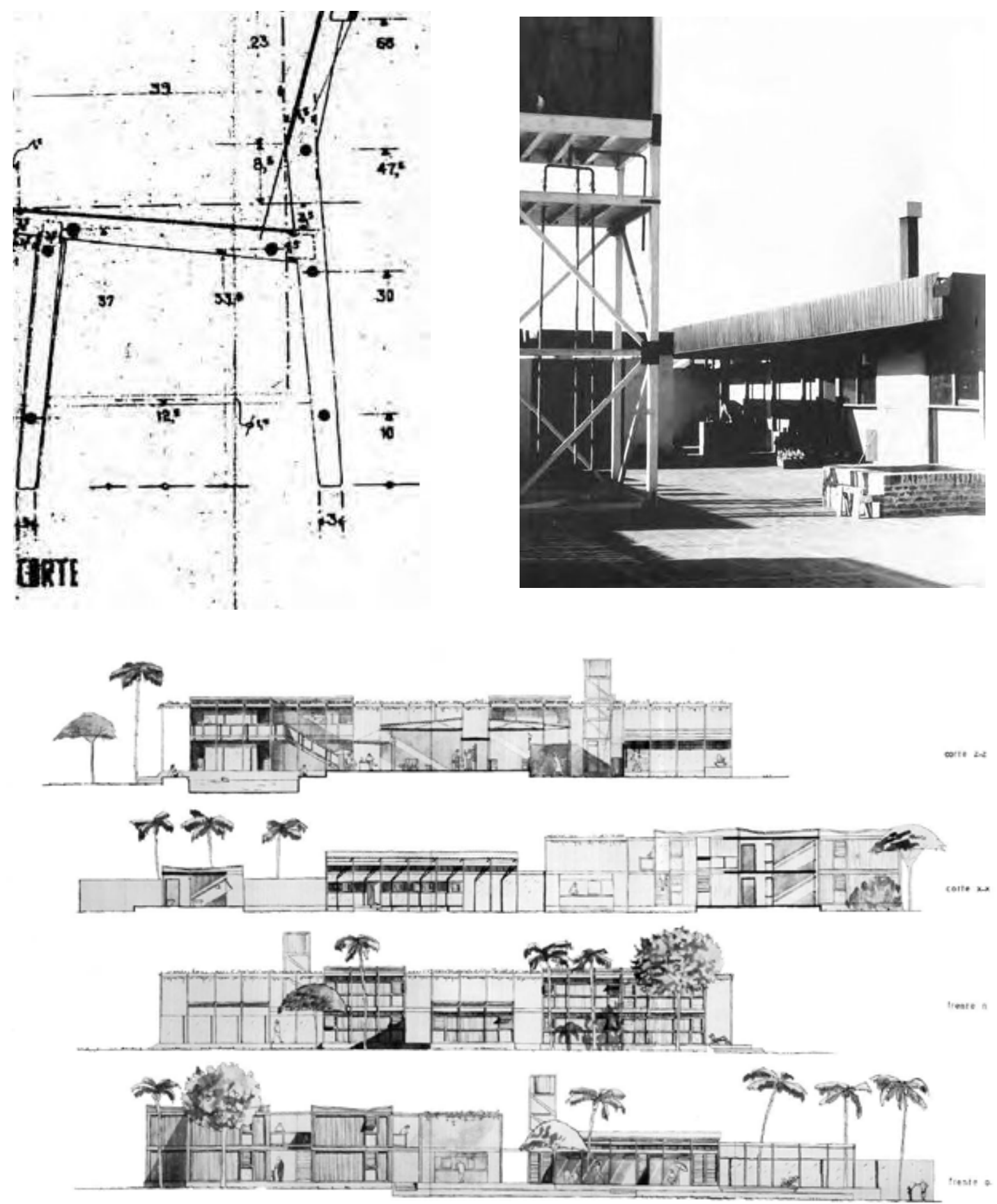

$72-73-74$ 

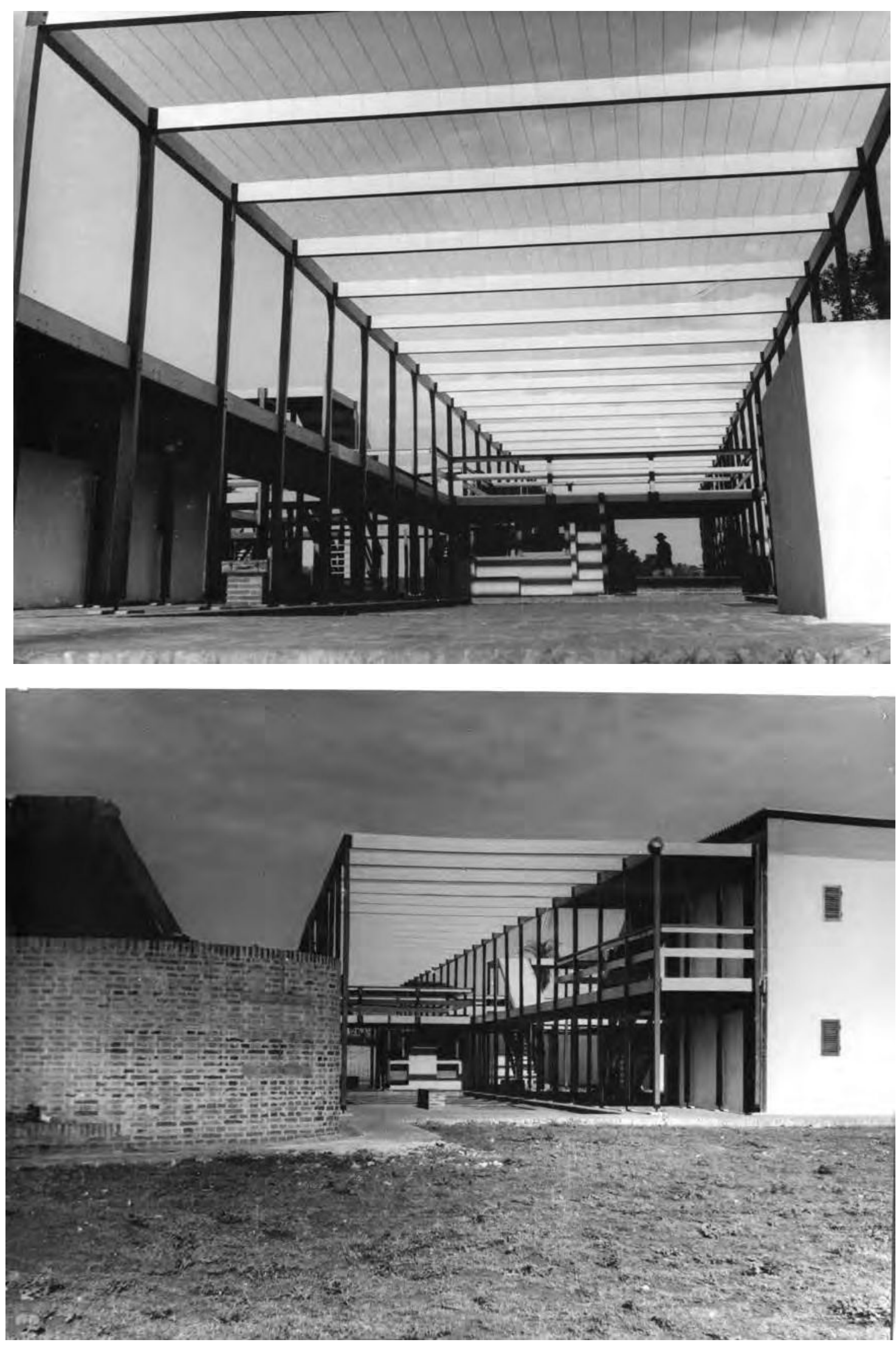

$75-76$ 
Segundo Plan de trabajos Públicos de 1957

\author{
Seis Hosterías de madera en Misiones
}

Anteproyecto Hostería San Javier, Paneles de vistas y cortes ante proyecto
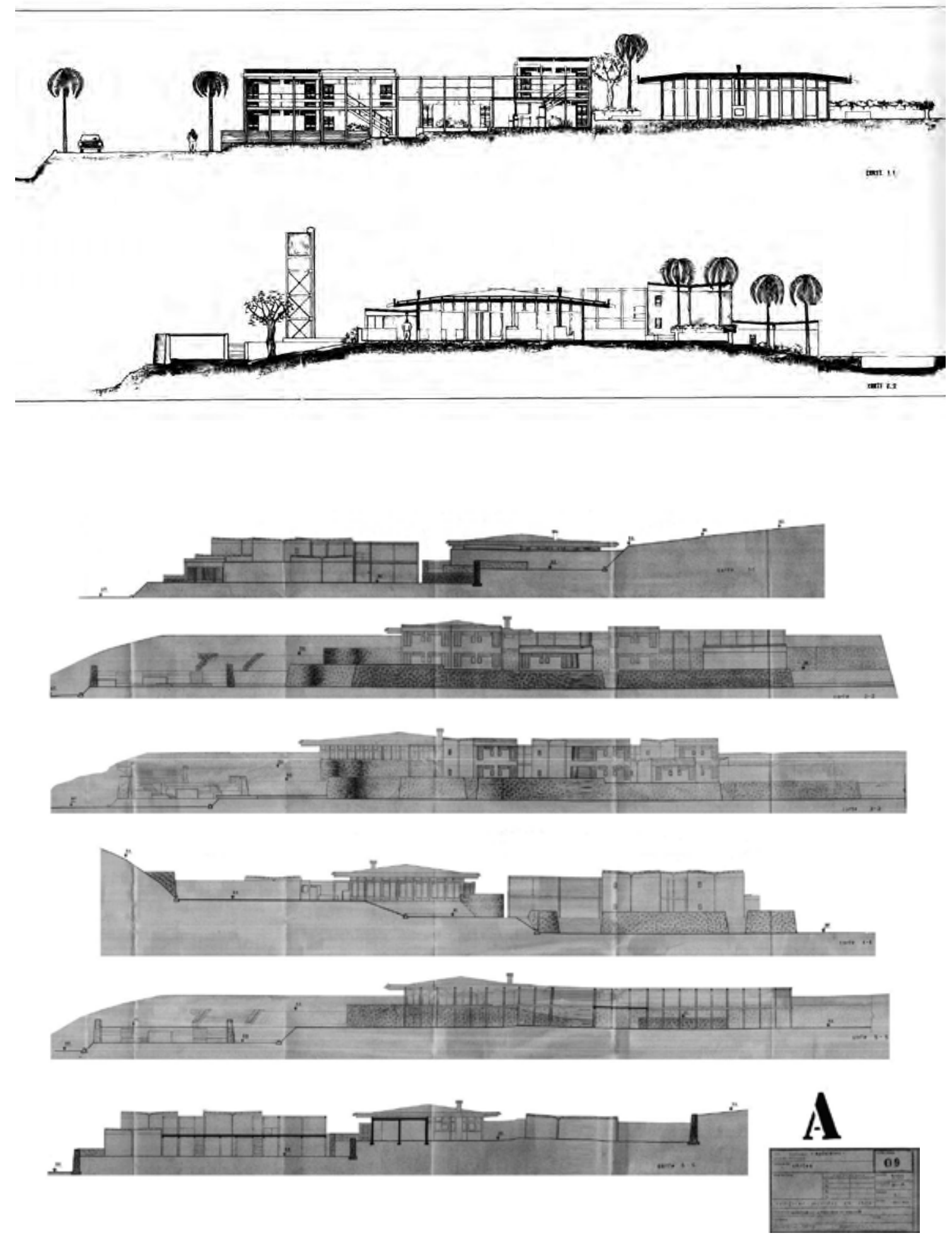

$77-78-79$ 

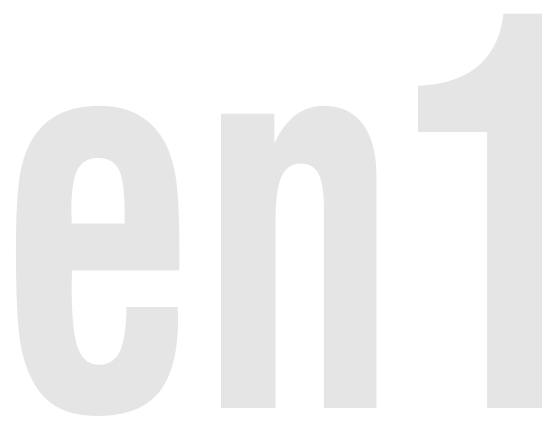

ESCUELA NORMAL N 1 EN LEANDRO N. ALEM

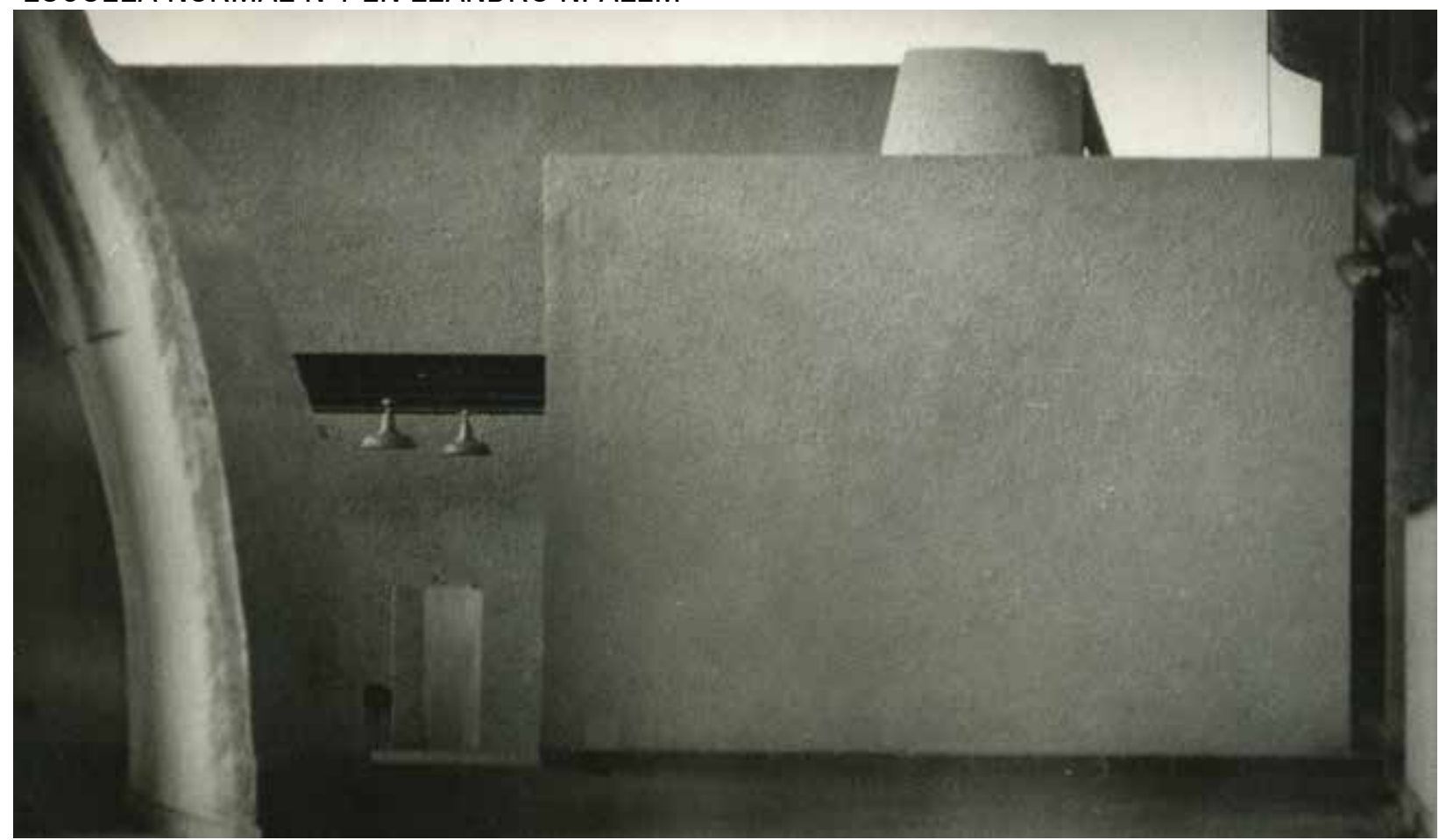




\section{Escuela Normal $\mathrm{N}^{\circ} 1$ en Leandro N. Alem}

Decreto y Expediente de adjudicación de obra
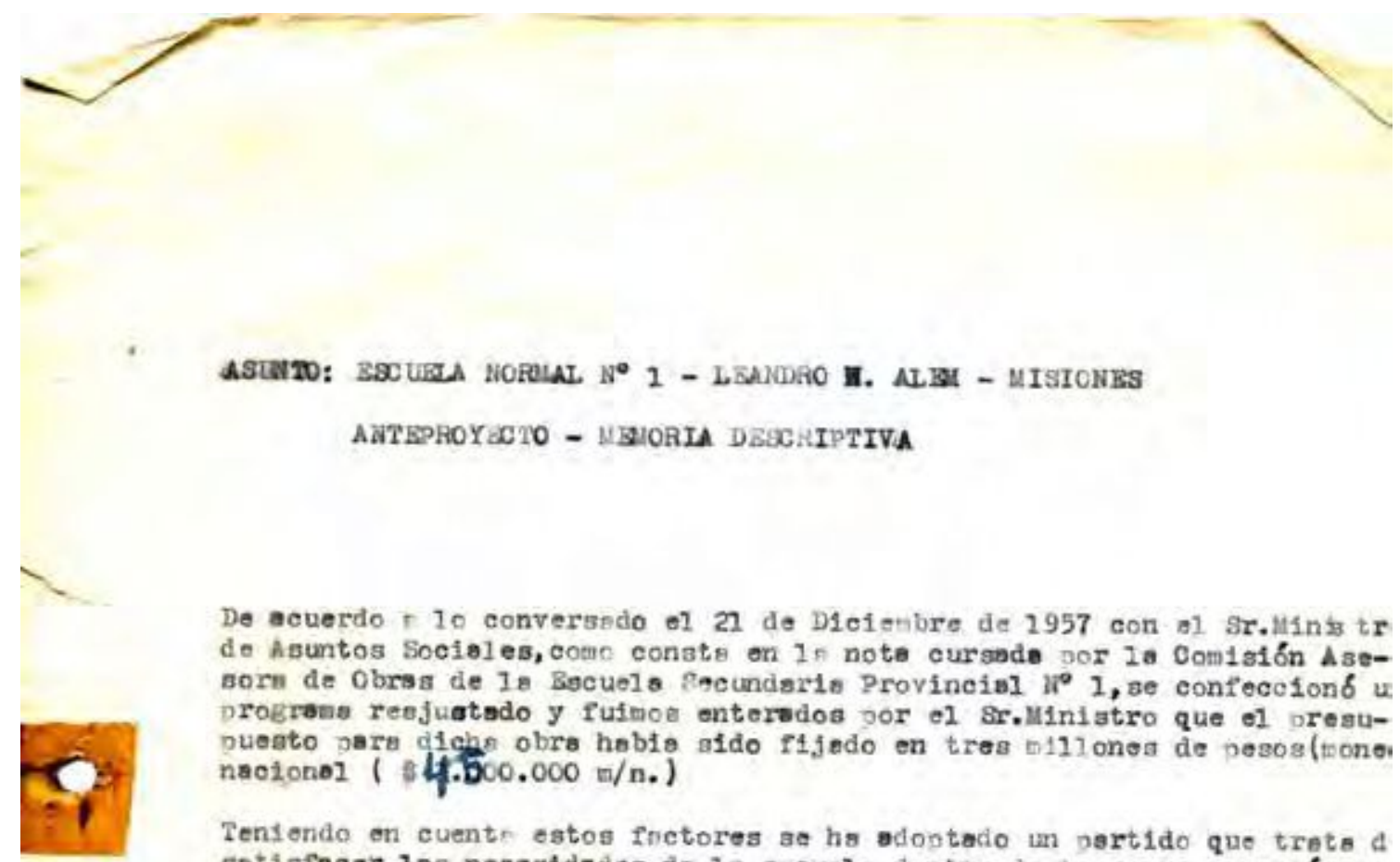

De acuerdo +10 conversedo el 21 de Dieietbre de 1957 con al sr.llinstr de hauntos Socioles, come consts on If note cursade por la Conisión Asesorn de Obrss de Is Becuels Racundarls Provineial $w^{\circ} 1$, se confeccion $\delta$ u probrans reejuatado $y$ fufmoe enterados por el Sr.Miniatro que ol oreau-

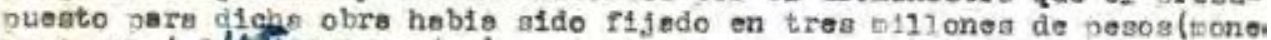
nactone1 ( $\$$ \$.500.000 $\mathrm{m} / \mathrm{n}$.

Teniendo en cuent estog fretores ae hs adoptado un partido que trete a satiefacer 1 as necesidadeg de la orcueli d ntro de is rayor aconomis no.

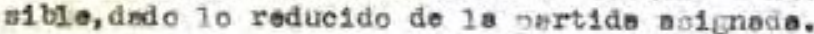

Por 1o temto 1 an enreteristicas del snteoroyecto aon 1 na alguiantess CONETKUC ION:

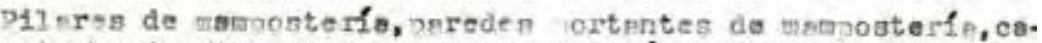
hios de mnders, techo de f1brocenento, loans de cerfútico a rupdo on sulfs, abiaetes, bafos, bibliotece y zon edrinistrativa, enrolntaris gtanderizac de nedera.Lon olson nerf́n de noselco erenftico, isa) vo que se juedan rect. alazer por otro mpterlel de bejor callded que en su osortunidnd se ofre: es $n$ buen srecio.

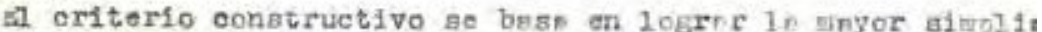

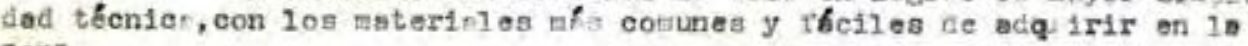
zons,

1) Concentración do loceles a fln de logrex in mayor econo-

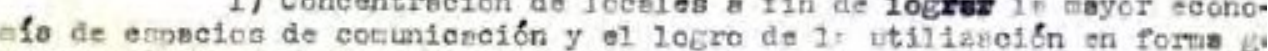
narott de 105 ospecios oevi-abiertioa por trediso de un aolo techo qua equa In encuele, dendo sombre y nroteifenco los loc:ler d neynr uso.

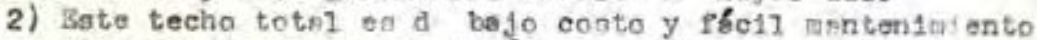

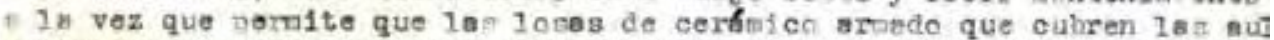

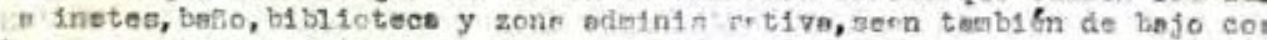
to ol no verge precinding $n$ siglarge hidrablictuente.

3) Datio cubierto $y$ selon de rotan, fir gido of visto ano ia 3olo Iecel do uso intemndo, ye que sa obvir lo itinosibilidad de la conat clón de un selón de ectos ndeó́: iel stio cublerto. Sate local nuede aej

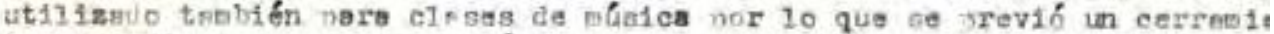
to corredizo bert au sislación.

4) Orientación: Vorto-Sur protestentono con vuros el Sate; el Deste, ye que 208 vientor benefieiosos corren sobre el sje Nerte-5ur.

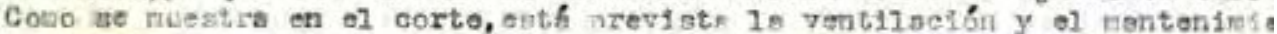

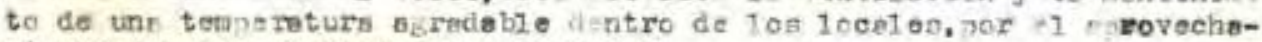
viento del 10 s Vlentos del sactor sur.

5) Hiveles: oueden no ser d Pinitivos suecto que onrecewos 

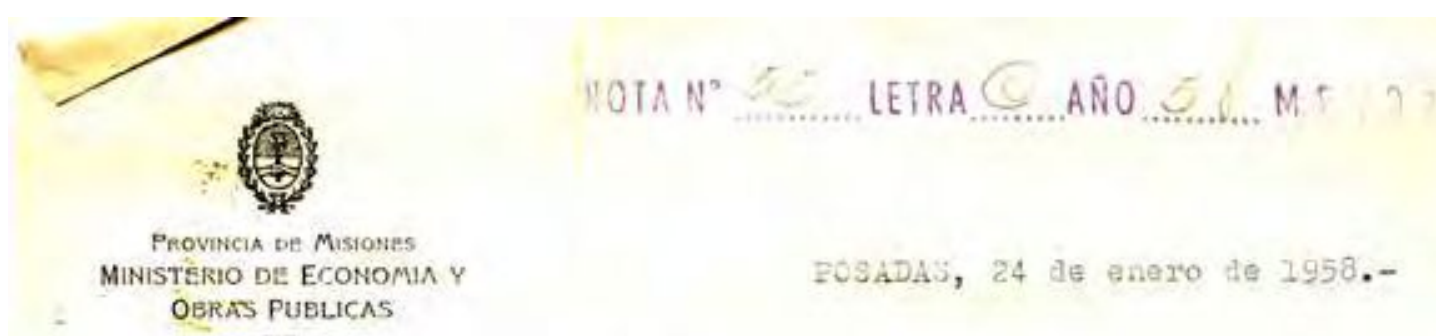

SBiores Arquitertod WOL R. EIVAROIA y MARIO B.SOTO, Stente F́ 1753

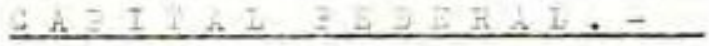

De mi meyor conatieración;

Cop. No.

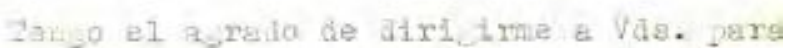
Vart a su conodidiento lo conventio con al seror Kini itro de Aeinta ciales, raprente a la concecoín de le socumsntación corresondie

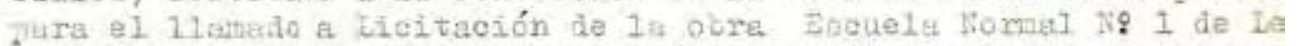
Iro H.Alem, encomentada a Via. se gin Jostrato suseri, to en zecha z Thovienore D. Lo.-

De la rounión realizada oon 103 repreast:

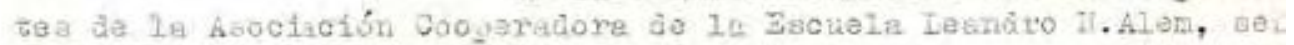

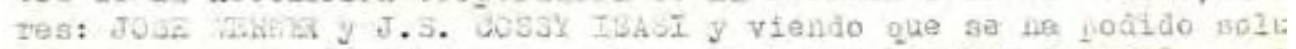

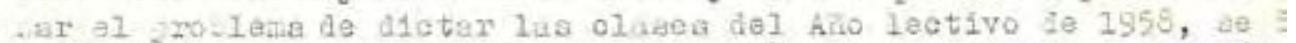

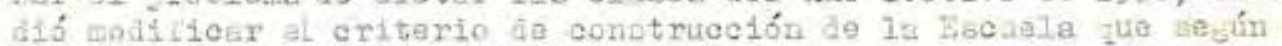
Concysto ilumedo gor Ia provinoia con Via., estaba yreviato en das 3es, la primera realizada gor el "aiatena gor edmimiesración" a oe de 12 Asociectón Coogertiora nomiortada, y le aesunde por un 21 amade Lloi tración fásllea.

For 20 tanto converaado el Ara. Hario $\bar{F}$. to nobre 10 antediono y viendo jate la poaidiliald de conteocional documentación pera el 1lamado a Iioitación le la obra completa, rif

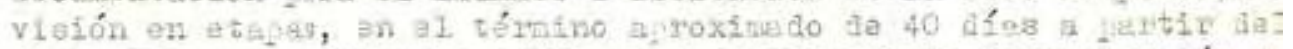

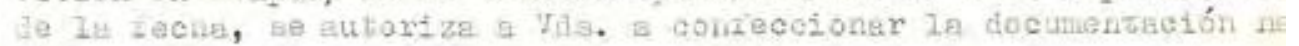
ria.

Astufiatio, existienlo là ampliación de pi te $3.000 .000 .-m / n$ a $\$ 4.500 .000 .-2 \sqrt{n}$ destinida e Aicne oora, se

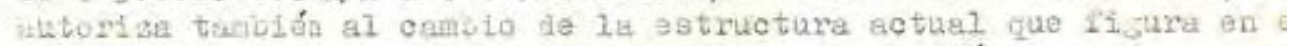

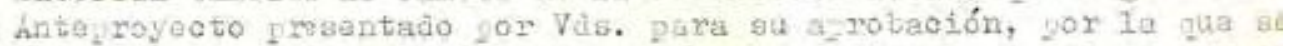
sidere, lueso dal estudio correzponaiente, tdeciala y gie be projec en horuigón smado, como así teubién a la incluaión y anglieción a

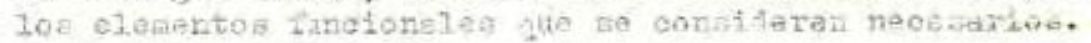

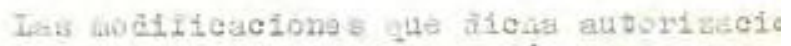

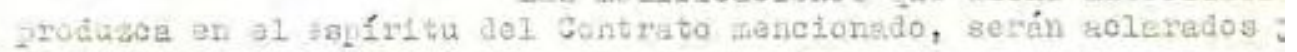

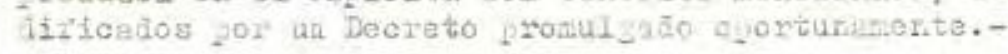
con muy ltomth gouniżeraciór.-

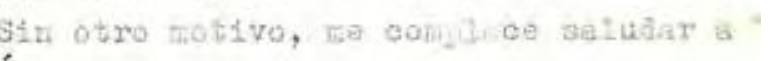

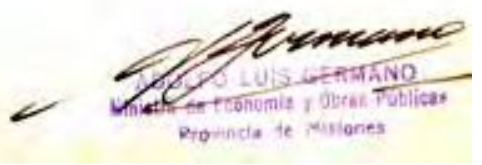




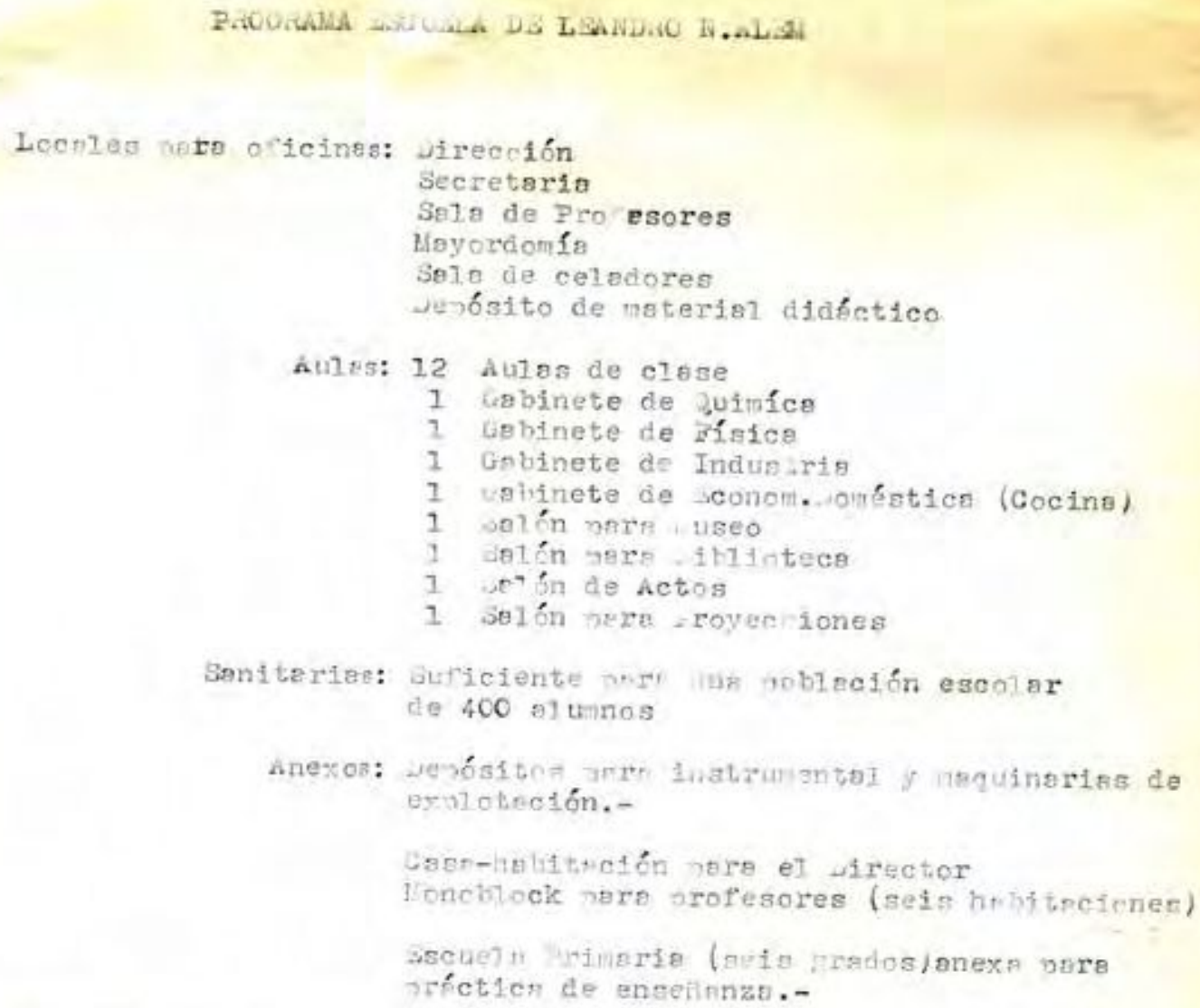

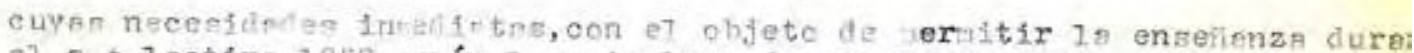
Q1 to lectiva 1958 tectín Th n letabros de epe dooperadore y los ectuales nrofesores de $2+1$ abcuele serít soto lnt siculenteg:

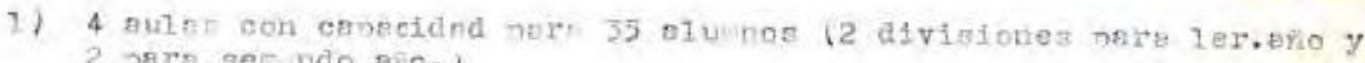

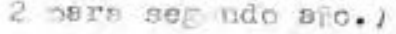

2) Direcuión

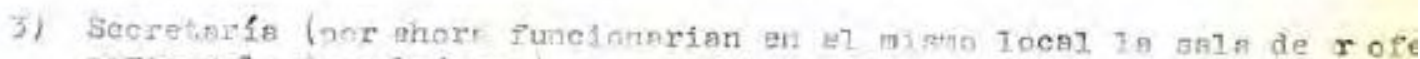
vores y to re celadoces)

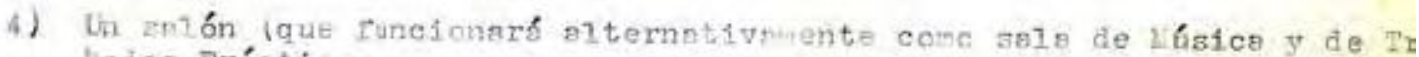
brion Prícticos.

5) Un ratio cubserto (que runcionaré tembien como Selón de Actos)

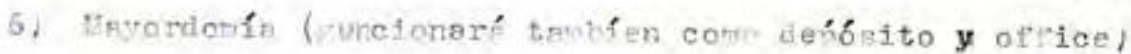

7) Beกิน:- 


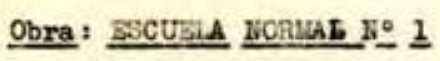

Uoicación: Leandro N. Alea - Pola, de Hieionea.

Frovecto I D1rocaión de Obra: Arquiteotos Rivarola - Soto.

Proyecto enosrgado en noviembre de 1957, diroctadente por el cobierno de la Provincia.

Obra terninada en 1963.

Costo rinal = $\$ 27.500 .000 .-$

Superficie: $2.870 \mathrm{~m}$.

Gefaculo de Bstructura: Arq. Alfredo Yantorno

Prosman: 12 aulae.

2 labosatorios pora ofenolas.

1 eula de manunlidades $y$ econonfa dombetics.

1 Biblioteca.

I Sala de mísioa.

Patio cubierto $y$ jatis abierto.

Zons administretivi.

Servicios Sanitarios $y$ vestusrios.

Caldere de agua colliante.

L.N. Mlem: $4^{\circ}$ cludad de la Frovizola be MialoneE.

Terenos Al borde del poblaio euave ponalente de Sux a Horte.

C11ina: Sub - tropical, hataedo. V1entos refrescantes Sux - Norte.

Planteor. ${ }^{\circ}$ Hediante acvimiento de tierra orear 3 planoe en el terreno: 1 para

Solue16n aulas, otro para laborstorios, biblioteca, adminiotrecion $\mathrm{J}$ eala de mása, el terrono para el patio cubierto, que con el misao nivel se extiende al patio exterior.

- Techos - parseol que ademss capta agua de lluvia que almacena on ofsterna elerpha och deabortes por gfrgolas, a fin de evitar costosas periorociones que hibben atroveos manto de nelafiro de oonsiderable eepesor. In klatones Buele ho hnber napas sinó ojoe de agua de diPlo1 ubtooson.

- Bajo el teoho, dioposioson de volúmenen 1ibremente dispustos, aproveohando contieionea del subtrópico. Leetersofón dal alro en moviater: to jor efecto Venturi provocsdo por forma te techo.

- Dif renein de temperutura resiatradsa:

Brtertor al sol $41^{\circ}$
Intertor de $27^{\circ}$ a $29^{\circ}$ 


\section{Escuela Normal $\mathrm{N}^{\circ} 1$ en Leandro N. Alem}

Decreto de aumento de asignación presupuestaria para realizar el cambio de estrauctura

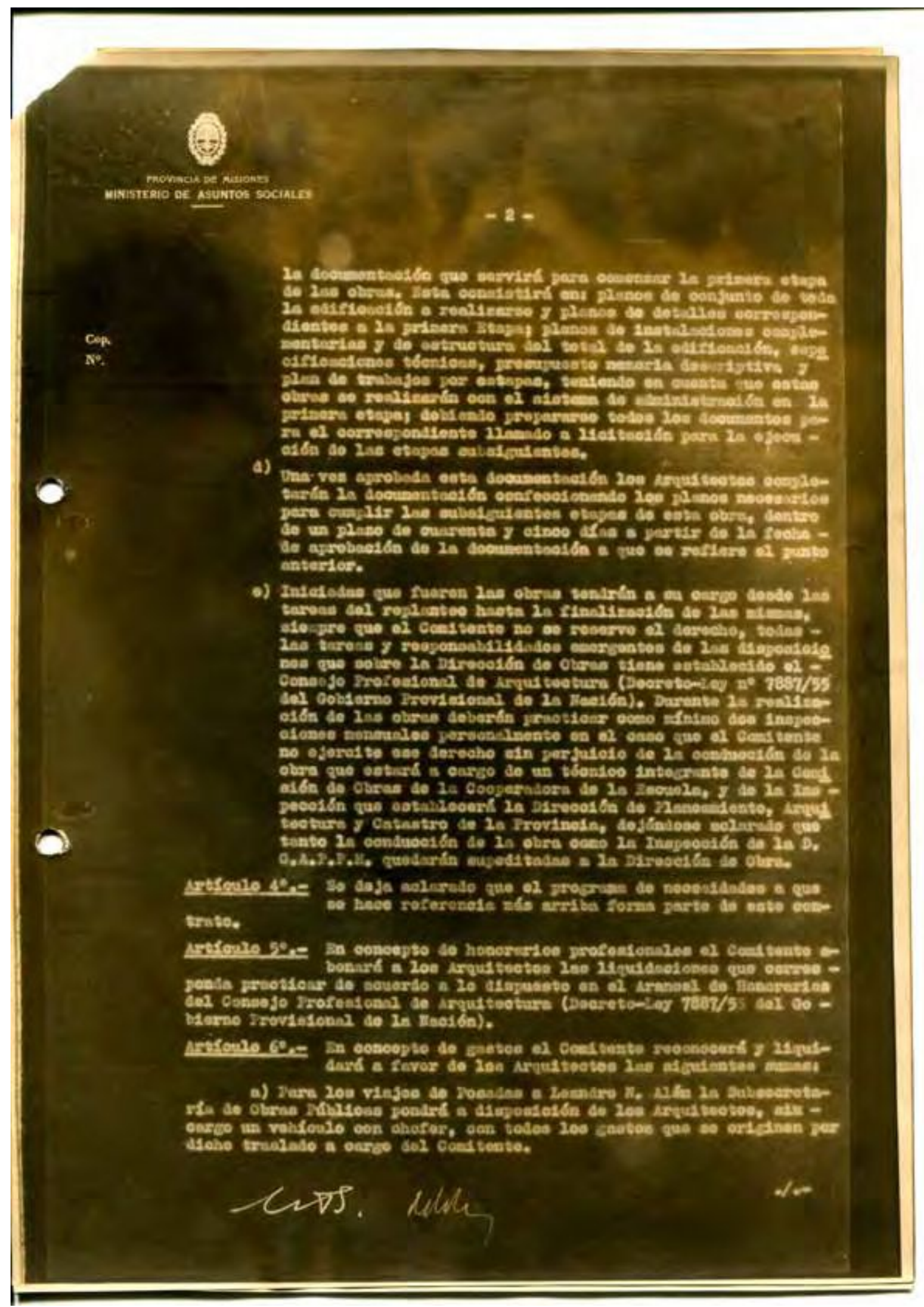



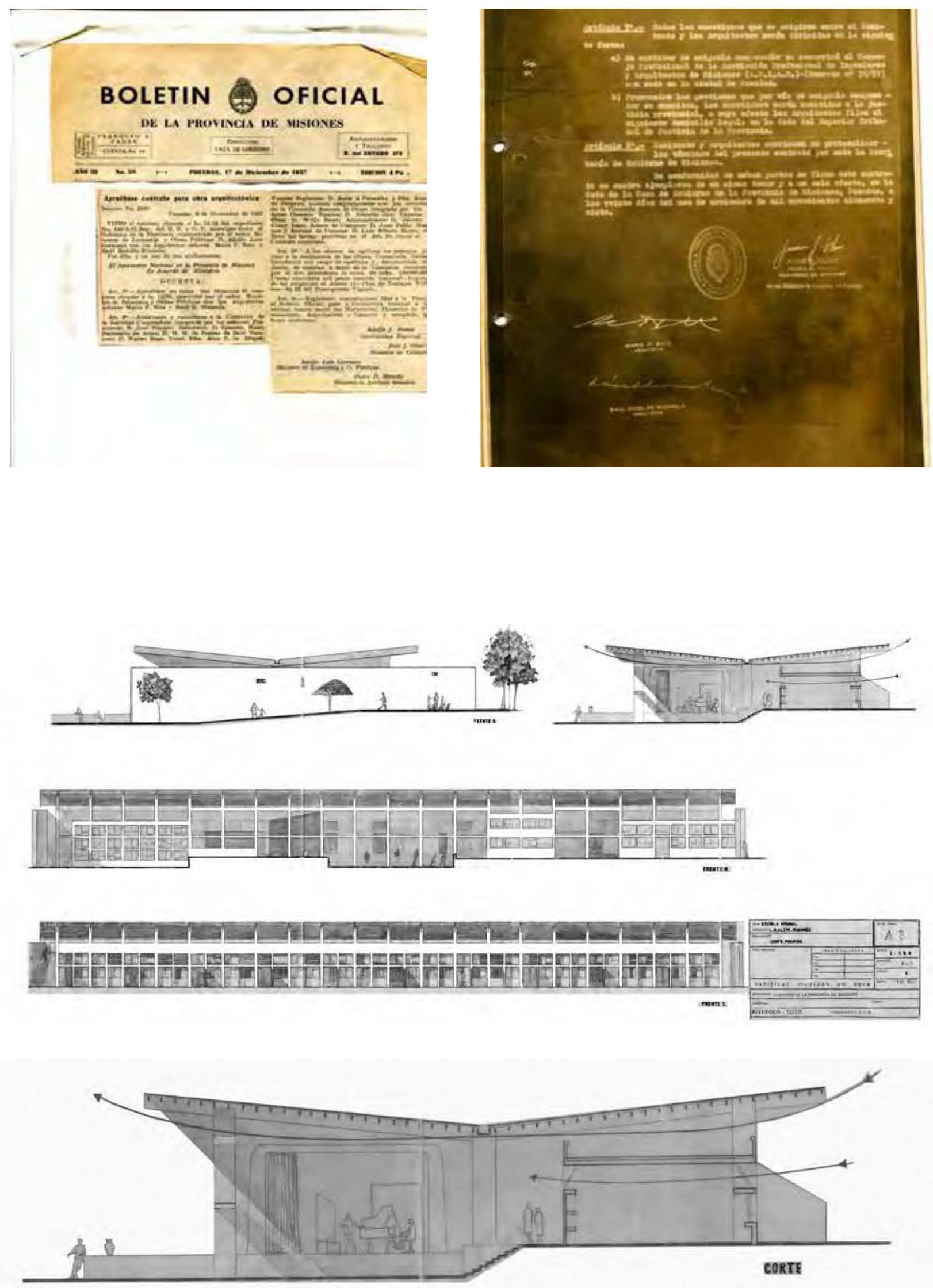

$86-87-88$ - 89 

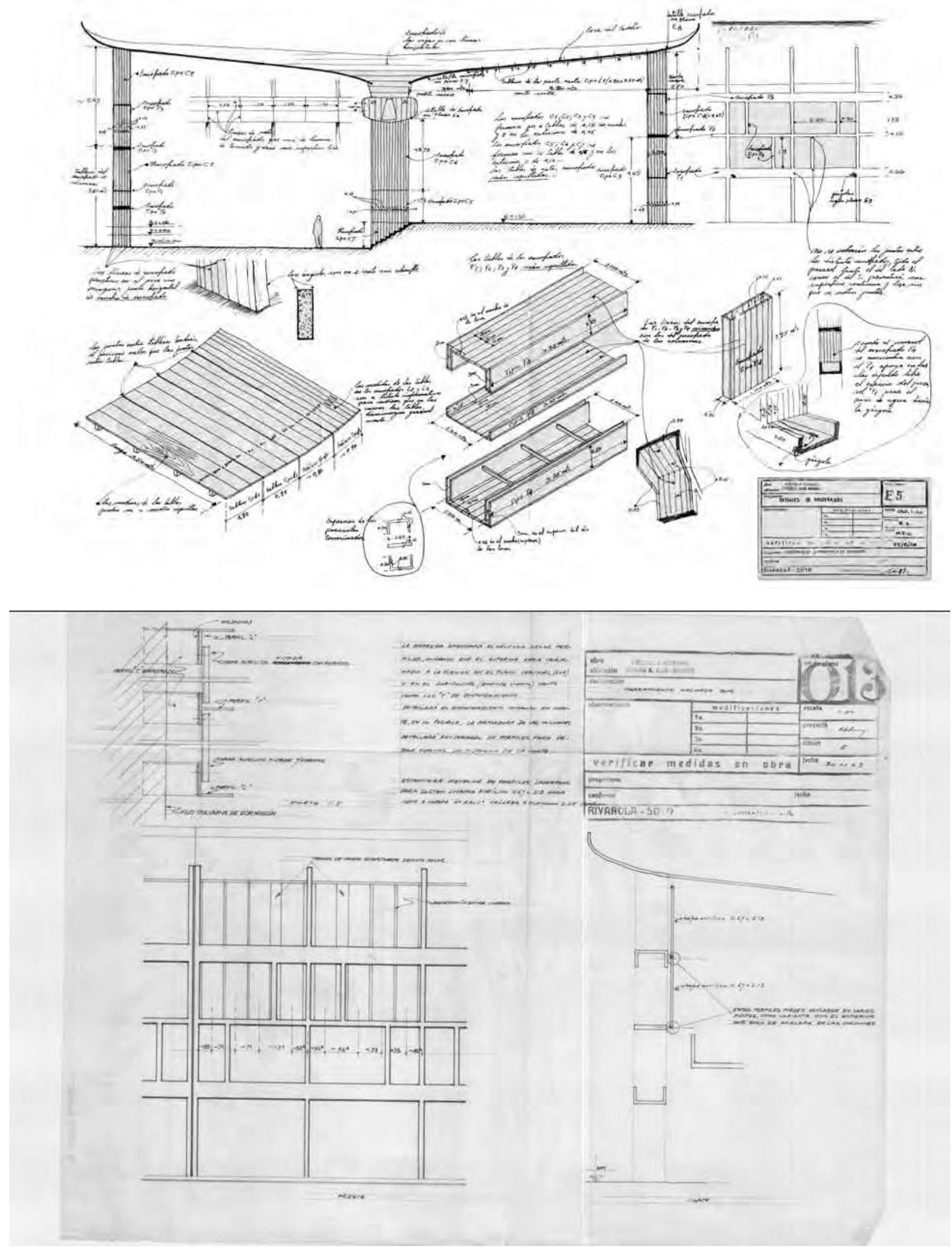

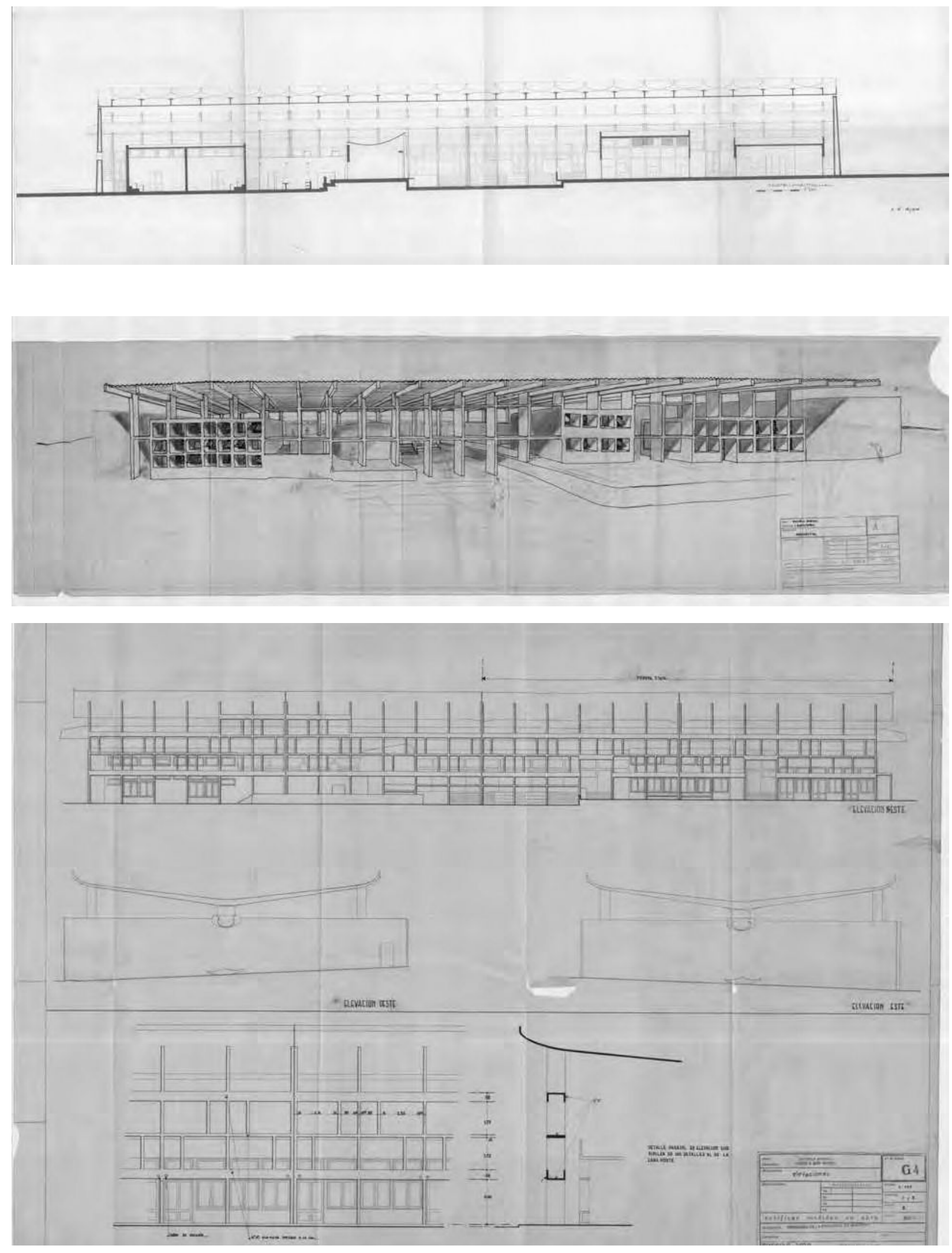

$92-93-94$ 

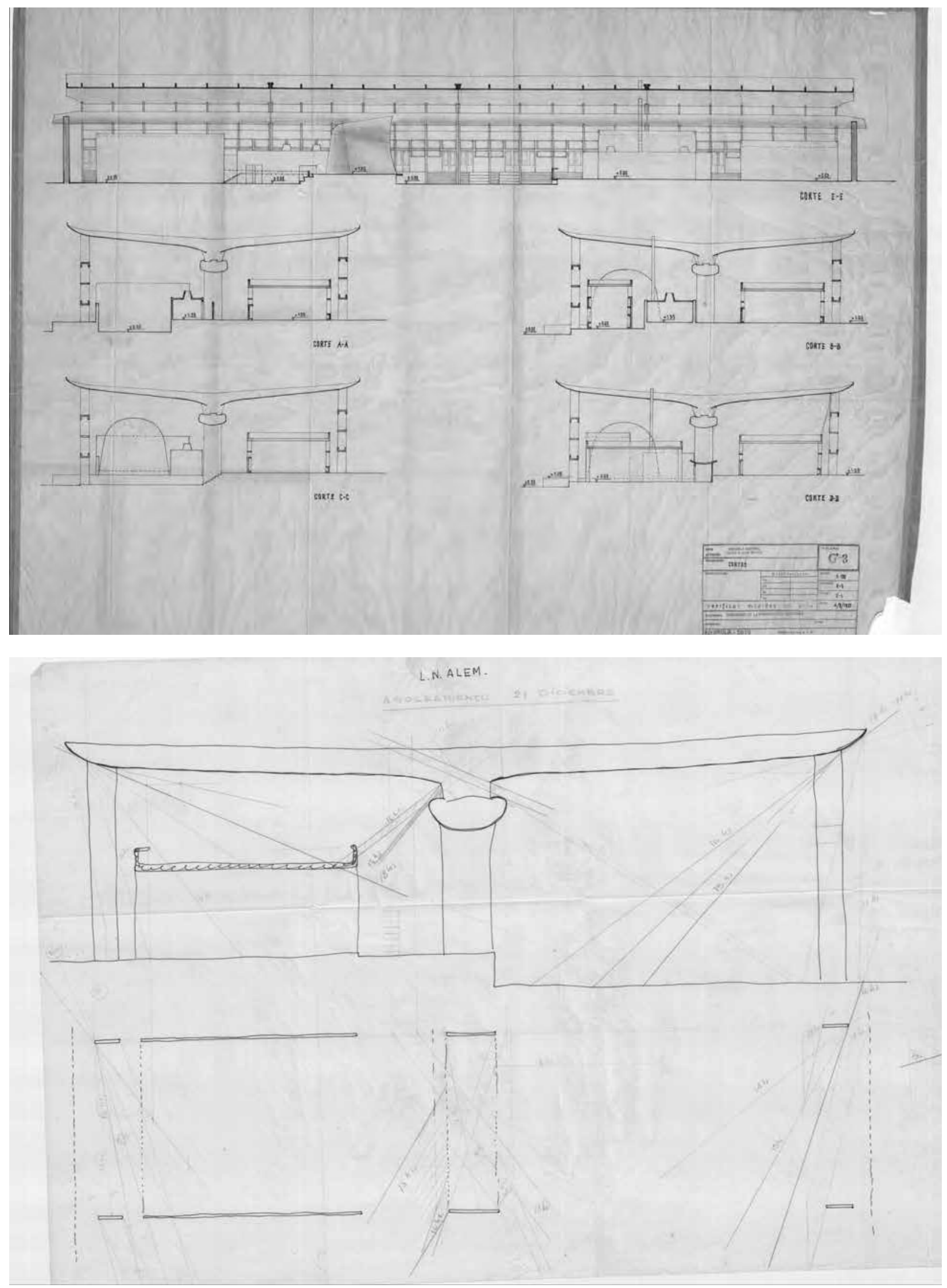

$95-96$ 

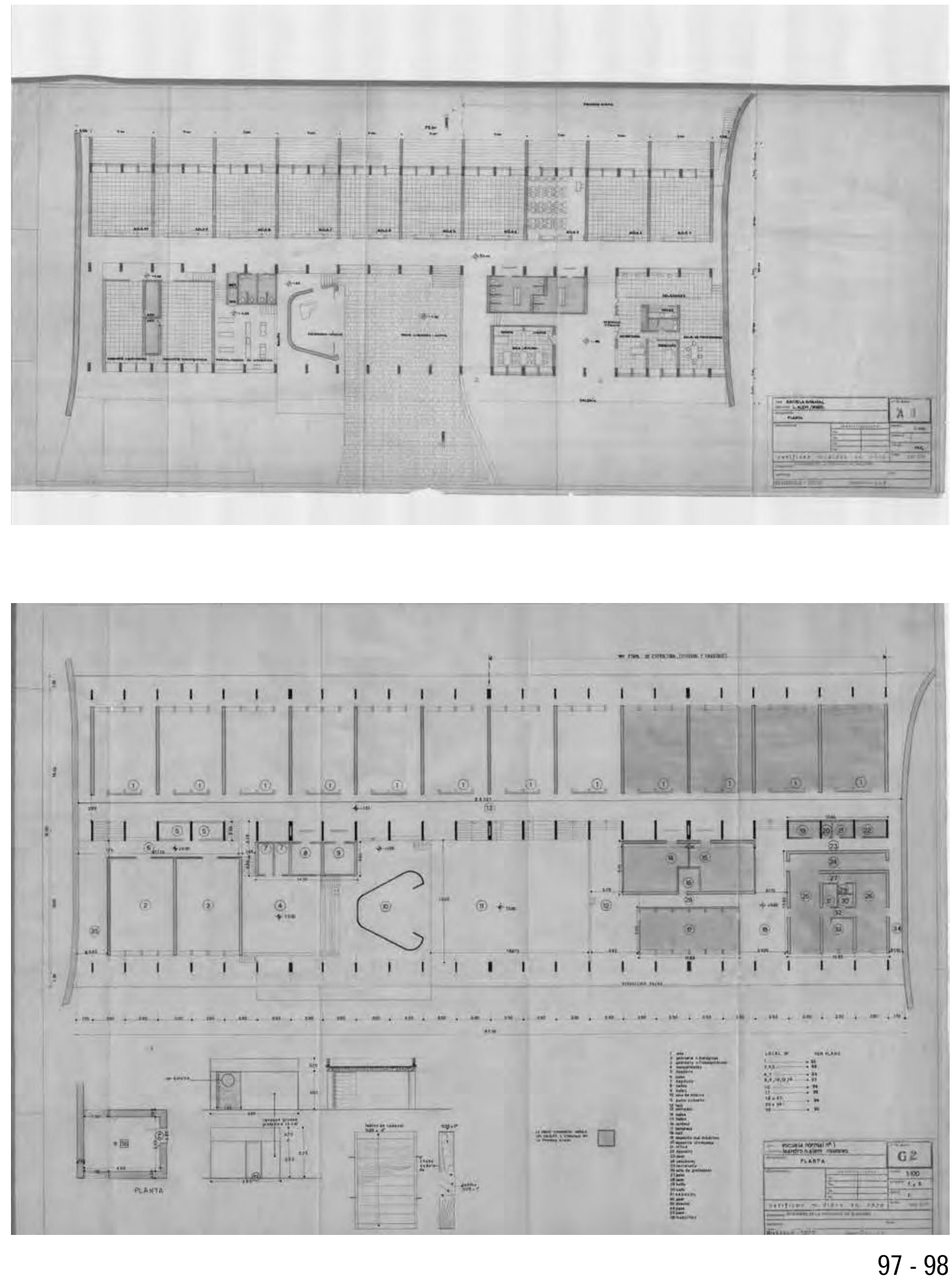

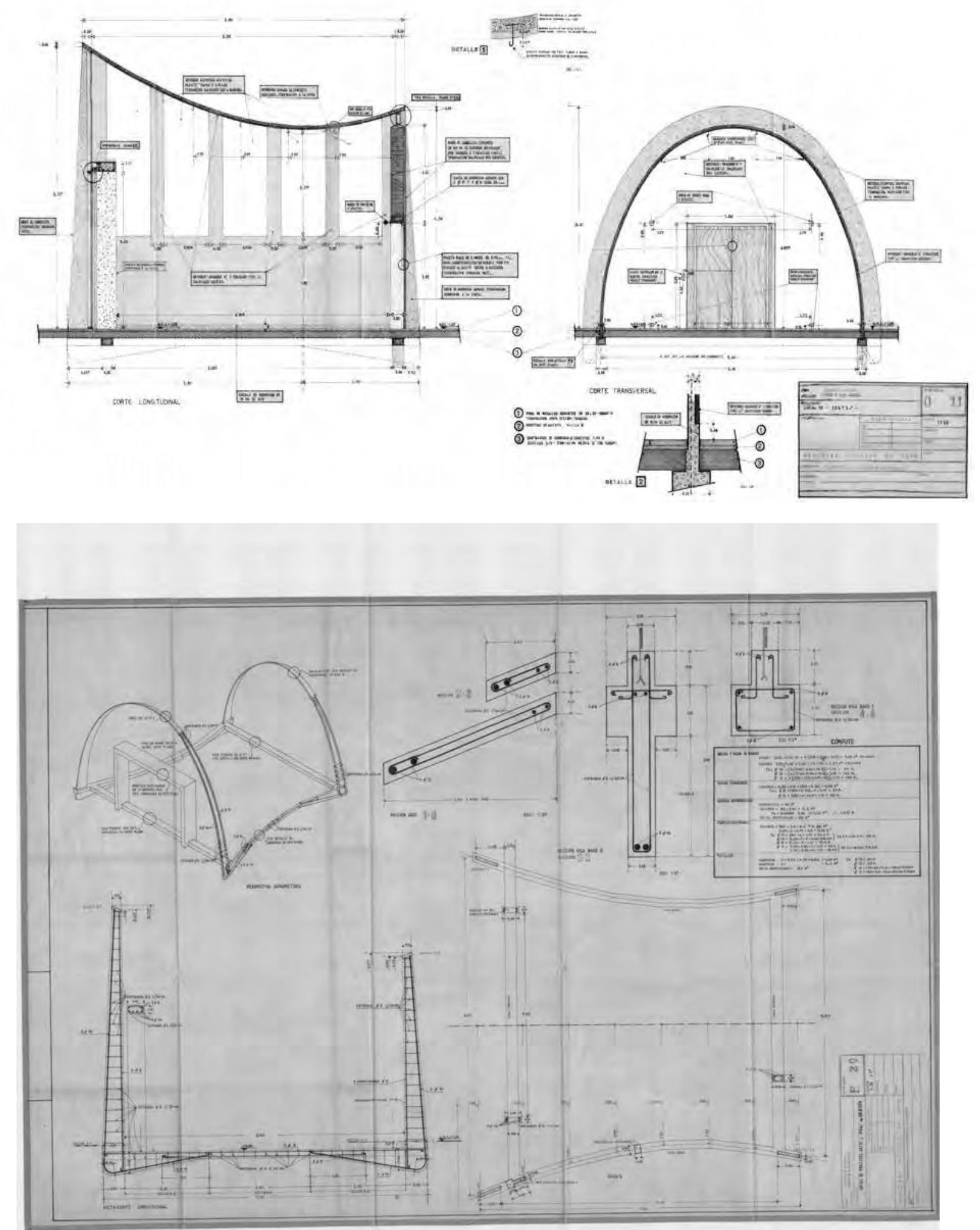

$99-100$ 

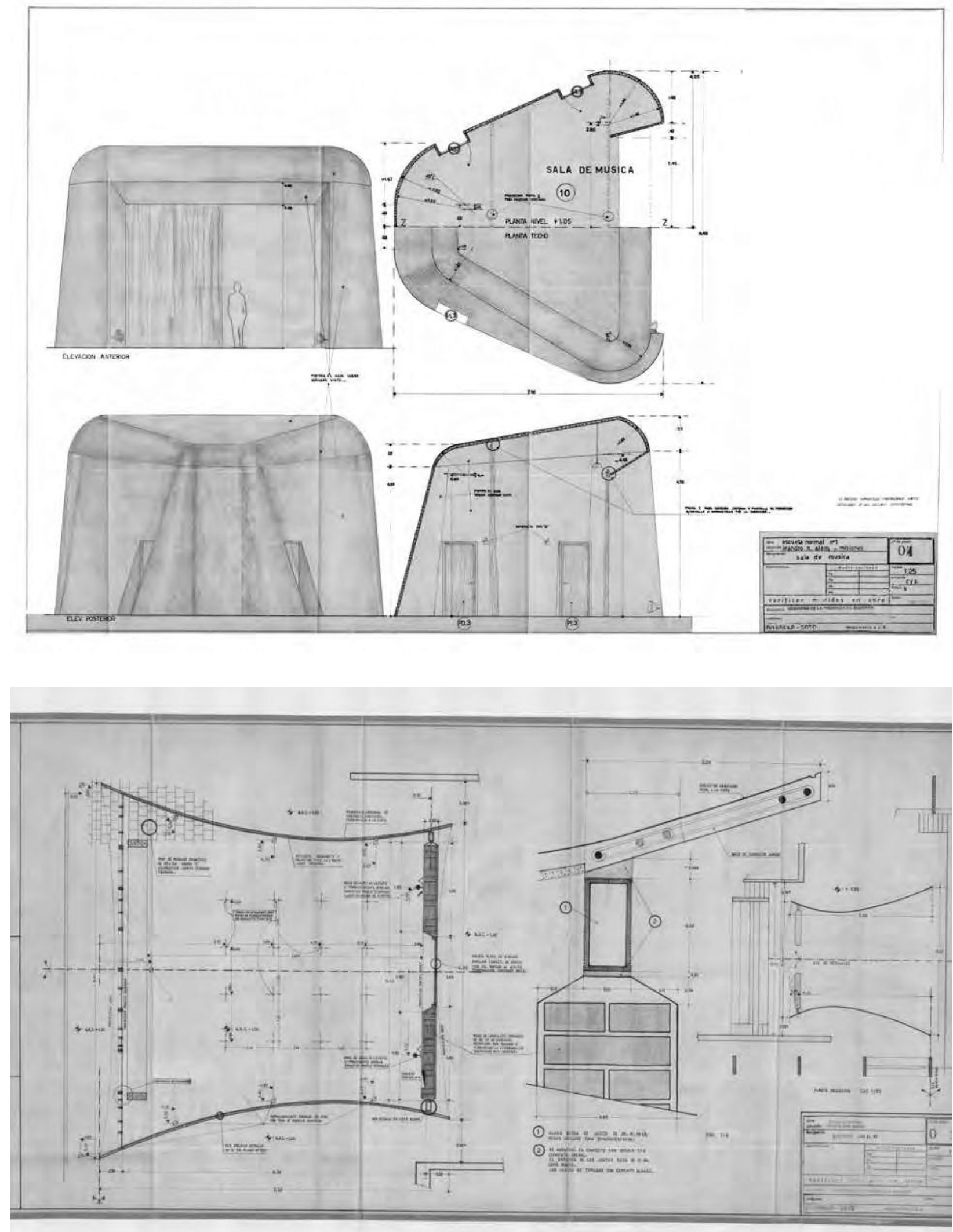

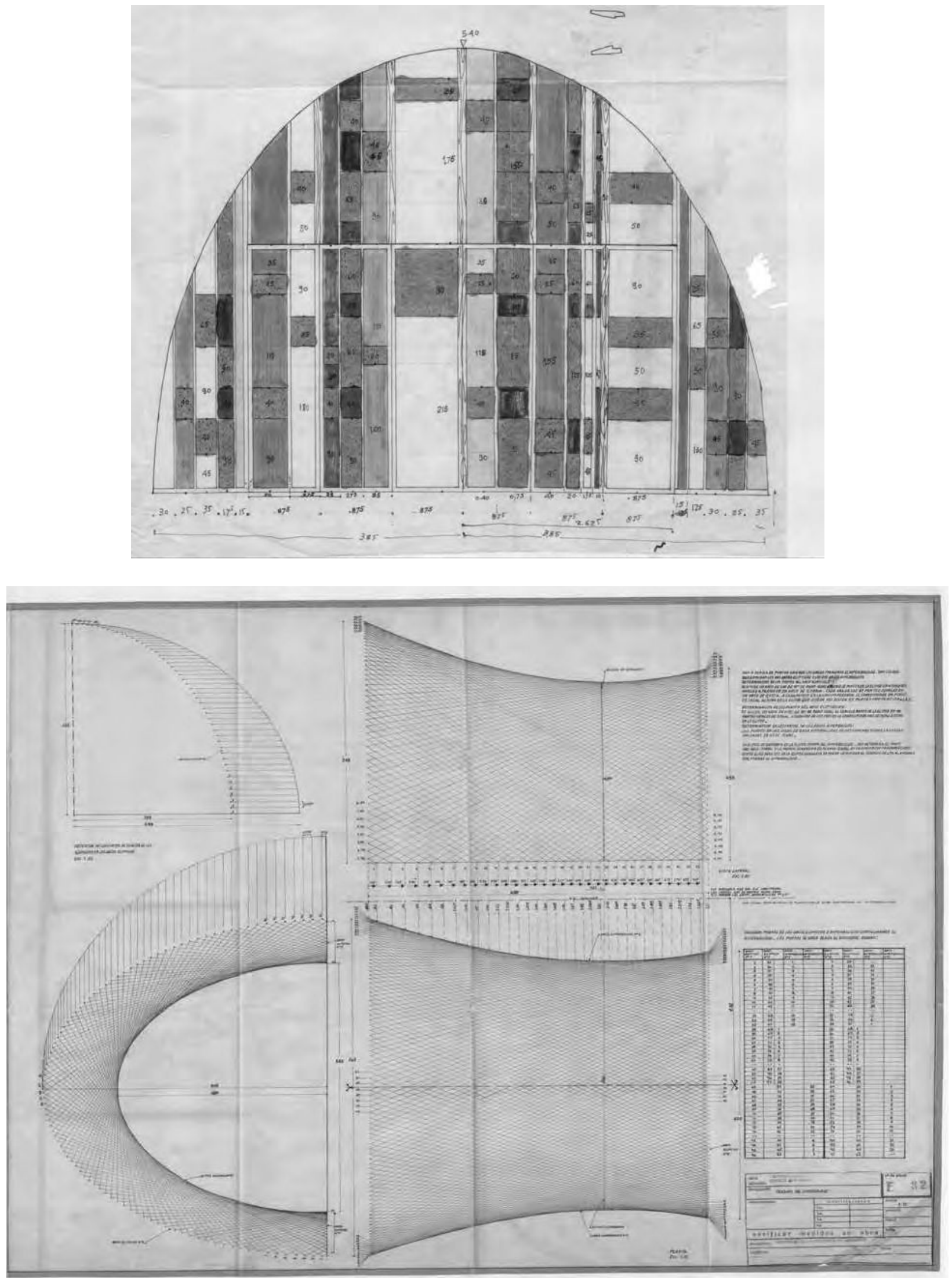

$103-104$ 

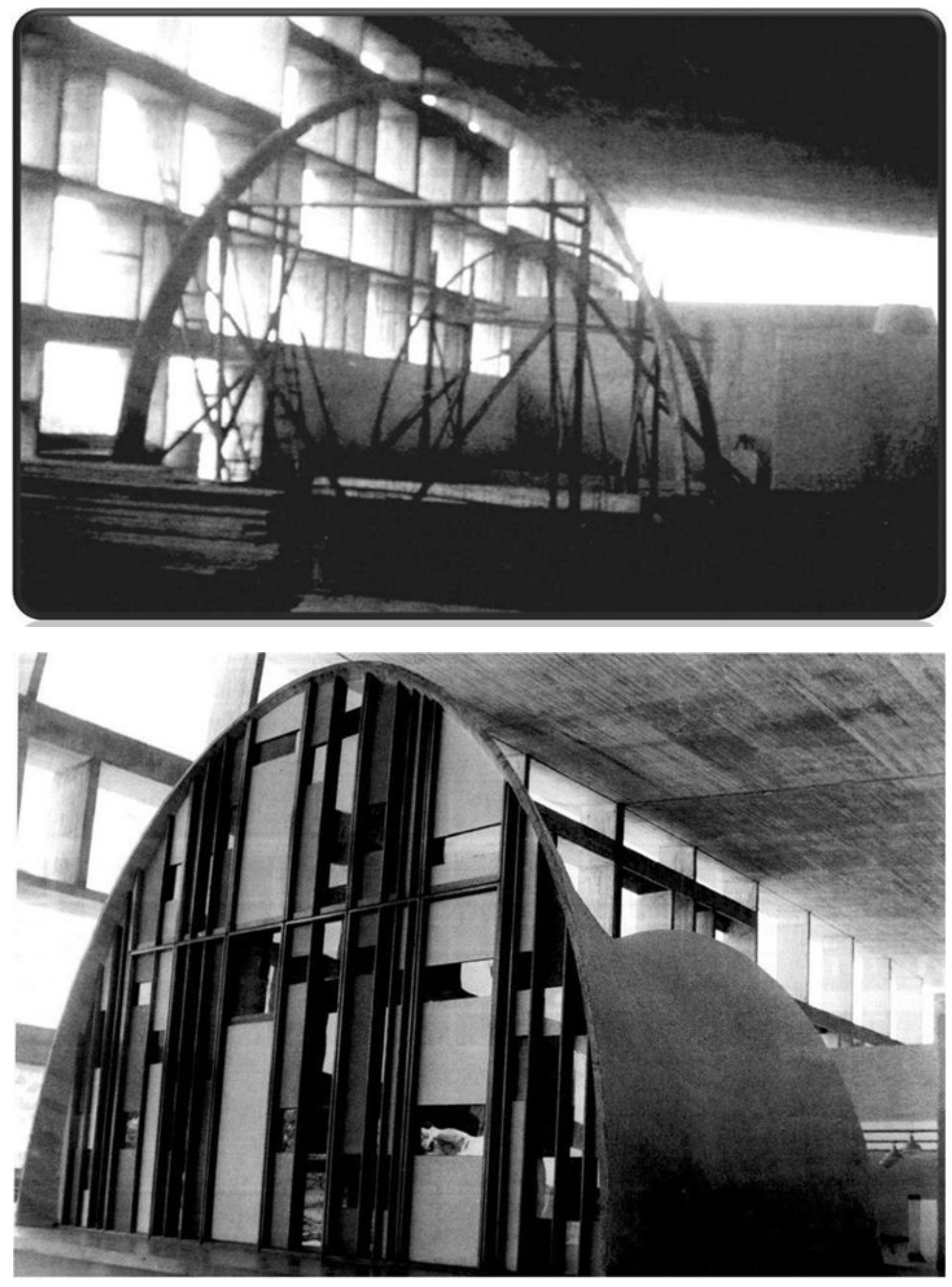

$105-106$ 

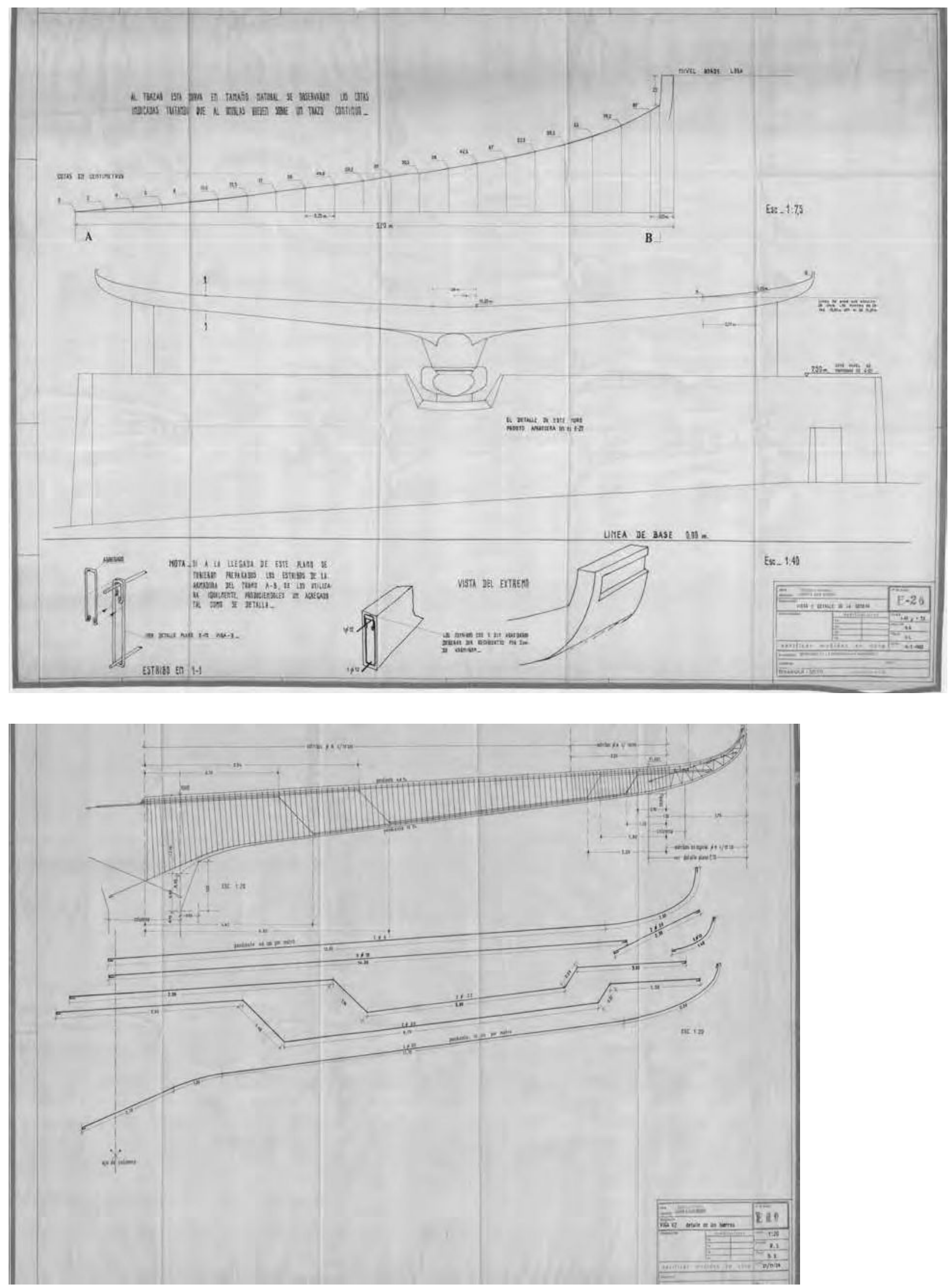

$107-108$ 

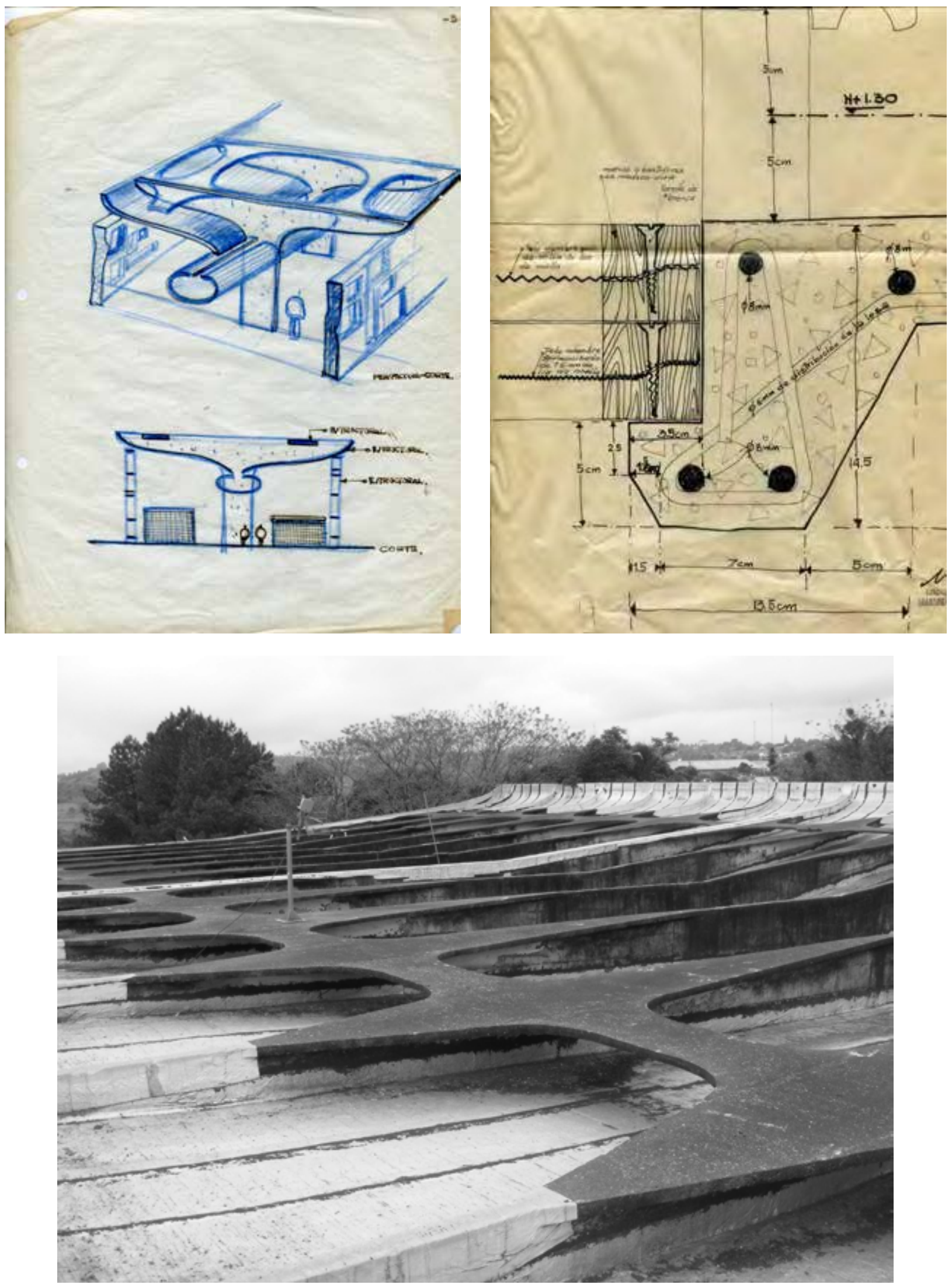

$109-110-111$ 

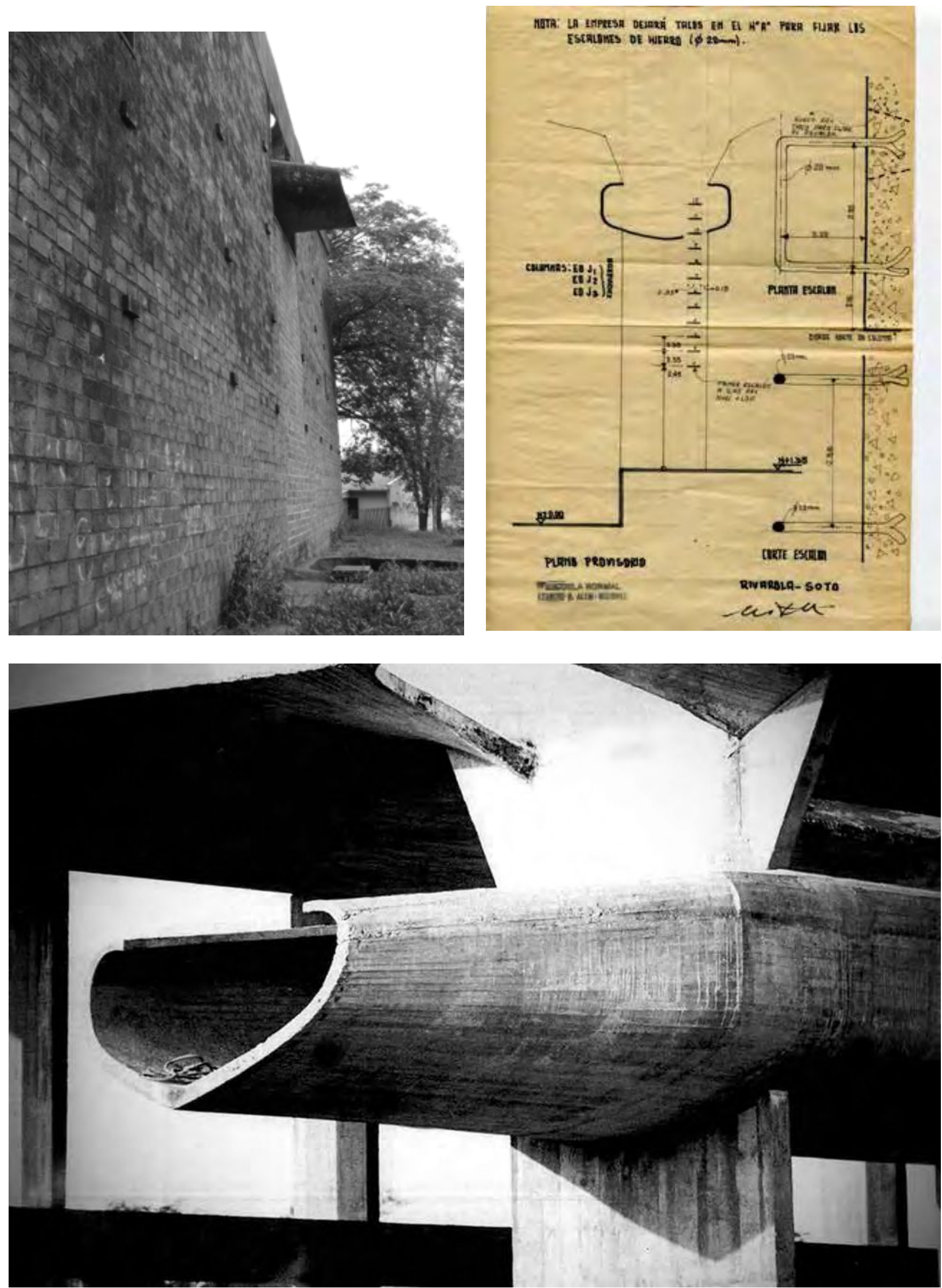

$112-113-114$ 

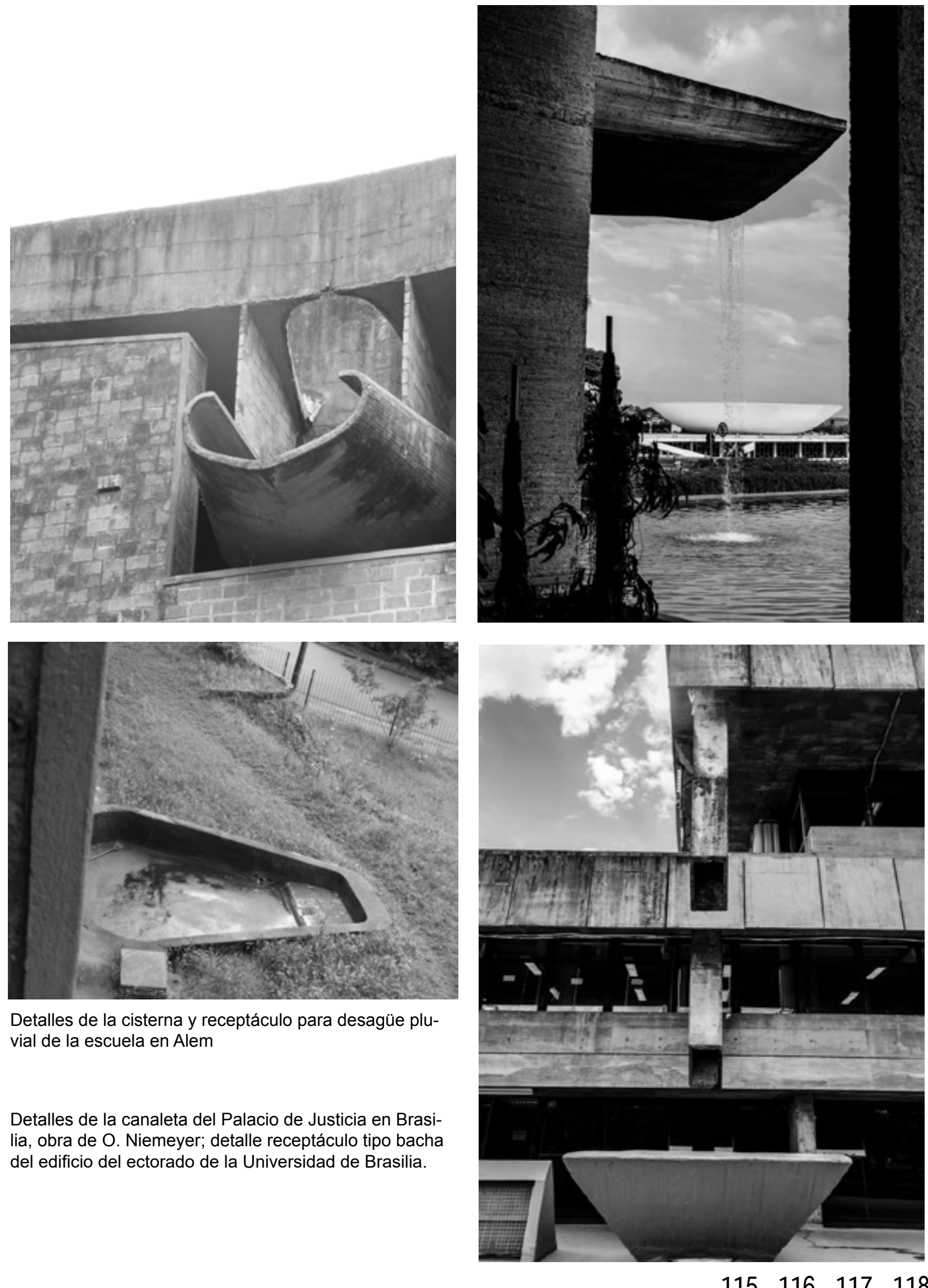

Detalles de la canaleta del Palacio de Justicia en Brasilia, obra de O. Niemeyer; detalle receptáculo tipo bacha del edificio del ectorado de la Universidad de Brasilia.

Detalles de la cisterna y receptáculo para desagüe pluvial de la escuela en Alem

$115-116-117-118$ 

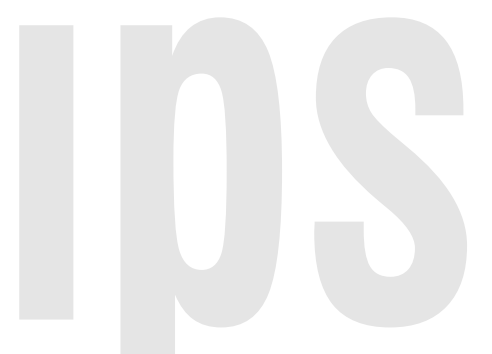

INSTITUTO DE PREVISIÓN SOCIAL DE POSADAS, MISIONES

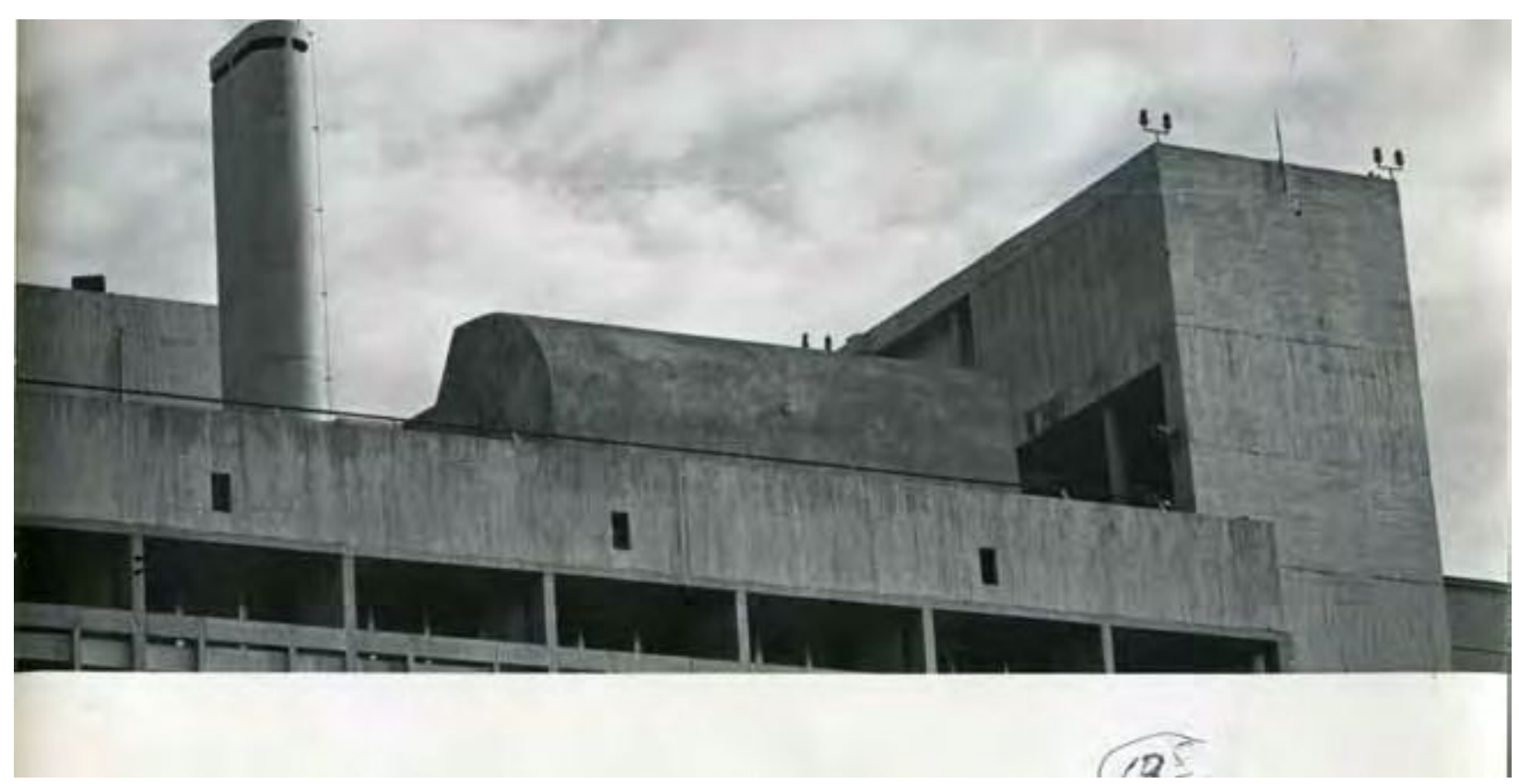


Instituto de Previsión Social de la Ciudad de Posadas

Fallo del jurado

CRIMICA TI BL JURADO HA REALIZADO AL PRESTENE ANTEPROYDCTO PRESENTADO AL CONCURSO PARA EL DDIFICIO DEL INSTITUNO DE PREVISION SOCTAL DE LA PROVINCIA DE MISIONBS

$$
-\infty-0-\infty
$$

\section{Anteprovecto $n^{\circ} 106$}

Partido simple y olaro, desarroliado en un volumen unitario y que oonflgura un bloque, unido por un cuerpo entrante, con el Bdifioio de Co rreos.- Plantas compactas, con medios vertioalea de oiroulacion bien ubicado, oonsigue que la totalidad del programe se oumpla on una cantidad modia de pisoe. El Gran valor positivo de aste anteproyecto resulta del manojo del espacio infe rior, en conexión con la calle, donde con un remarcas e sentido imaginativo, so ha jugado con medion niveles, obteniéndose ass un eapacio recorrible interiorexterior muy de aouerdo con las condicionea olimatioas del aitio y de indudabie interø̊s.- Dentro de esa galerfa, destácase la ubioación de la confitería, que partioipa, adembs de la vida del hotel,- Bien diferenolados 10 accesos y nú cleos de oirculardón vertical, tanto del Inatituto como del Hotelo-

Las dependeneias del Instituto $3 e$ desarrollan do manera 6́ptima, en solo dos pisos, con una clara diferenoiación lie lis parte de ptblioo y jerarquizando e independizando las secoiones direotivas, en la oabecera del edifioio. La planta tipo de hotel se resuelve con un núnaro adeouado de unidades que sa tiaface la eoonomfa de servicio.- Las unidados del hotel se ven valorizadas con el agregado de una "veranda" anexa a cada una de ellak, elemento que se conside ra muy adecuado a las condiolionoa dol climaj- Objetable la ubioación de loa sar nitarios al frente en las dos plantas del Instituto, lo que ha originado el paño lleno de fachadas elemento que puede ser objeto de un estudio posterior.- Ob jetable el saliente sobre la calle Junin, que contradioe lo ospecifioado en las Bases del Conourso.-

La oaja de ascensores del Instituto, bloqueada on le mitad de la eltura del bloque, necesita un ap jom-3ngrrollo vertival, 10 que obligaria a

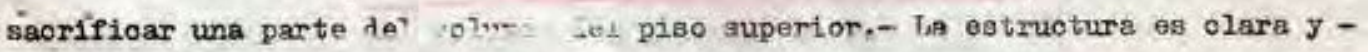
de una modulacibn acorde con las carasterístioas del proyeoto, 9xaltándose los puntos de apoyo en la parte baje del edifioio, lo que oarateriza por otra parte, un virtual acoplaniento con el beamento del Correo.-

Pese a lo valores crotados, el Jurado advierte que el anteprovent.n trasimtia niertia lierereza en su eatudio o imoreciaiśn en el detalle - ta- 119 
Instituto de Previsión Social de la Ciudad de Posadas

Fallo del jurado

-2- 103 los oas 00 del nivel de los e00e00s a la galería en relaoibn a la vereda, ol nimero excesivo de ascensores, la entrada do servioio por la oallo Bolfvar, $y$ la ubieselón de las măquinas de los acoensores dol Instituto al nivel de la gale ris.-

FDO2 Nrquitectos, David BERJMUS, Rafl O. GRBGO y Mauxloio REPOSSINI - Mi embros del Jurado -

\section{ES COPIA FIEY}

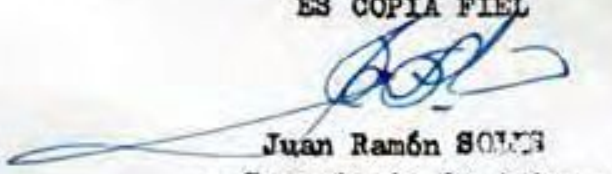

- Secretario de Actas -

- Jefe del Departamento de Cóm putos y Liquidaoiones del Insti tuto de Previaión Social de la Provinoia de Misiones - 


\section{Instituto de Previsión Social de la Ciudad de Posadas}

Memoria técnico-descriptiva de los autores

Memoria técnico-descriptiva:

El problema - Ia solución adoptada: partido, construcción.

Clima: Micro clima que se acerca al tropical con un corto invierno que no dura más de quince a treinta dias. Lluvias muY intensas $Y$ fuertes temperaturas ubican rápidamente al clima tropical, moderado en parte por los vientos del sur, frescos $y$ estimulantes $Y$ por las noches generalmente templadas. Dada su latitud, Posadas aun en la orientación sur, recibe sol durance las primeras $Y$ últimas horas del día $y$ por consiguiente este frente debe sx protegido en los edificios tanto como el Norte.

La actividad se inicia en posadas entre las 6,30 y las 7 horas $y$ se interrumpe al mediodia. La siesta resulta biologicamente imprescindible. La actividad se reinicia a las 16 o 17 horas $y$ continua hasta entrada la noche; entonces la ciudad se vuelca decididamente al exterior.

Paisaje: Posadas está frente al Río Paraná, puede vislumbrarse prácticamente descle cualquier cruce de calles. Enfrente se ve la ciudad de Encarnación, en el vecino pais de Paraguay. La pavimentación de las calles no es de lejana data $y$ aun no está totalmente terminada en la zona céntrica. El aspecto netamente urbano del centro posee tipicas diferencias regionales; el automóvil último modelo alterna con el carro tirado por caballos y la vendedora de chipá, compite con la heladeria "uso napoli" (...) Contemplada desde el aire, posadas aparece como una ciudad construida casi totalmente en planta baja, extracrdinariamente verde, con patios. La arquitectura domestica carece de las importantes construcciones coloniales que existen en Corrientes $Y$ en los alrededores aparecen las casas de paredes de tablas $\mathrm{y}$ techos de tejuelas de madera acompañadas de frondosas enredaderas que luego se repiten en toda la campina. La carencia de una fuerte tradición arquitectonica permite la creación de una nueva tradición que evitando moldes, contribuya a formular una arquitectura para Misiones.

Problema Funcional:..la dimensión $y$ el destino del edificio imponen el aporte de técnicas avanzadas, para crear en el hotel $y$ en las oficinas condiciones adecuadas de confort. El 


\title{
Instituto de Previsión Social de la Ciudad de Posadas
}

\author{
Memoria técnico-descriptiva de los autores
}

\begin{abstract}
aprovechamiento máximo de los recursos arquitectónicos, balcones, parasoles y terrazas, para resolver problemas de orientacion, asoleamiento $y$ vientos, sumados a la incorporación de equipos de aire acondicionado deberán confluir para lograr aquellas condiciones.
\end{abstract}

Solución Adoptada: Funcionalmente el edificio se compone de tres partes principales: oficina, hotel $Y$ galeria comercial, a la que se agregan como anexos el restaurante y la confiteria. Las oficinas tienen horario matutino, la galería comercial funciona durante todo el dia, lo mismo que el hotel, la confitería $y$ el restaurante. Cada uno de los tres sectores principales tienen accesos $Y$ circulaciones independientes; ek conjunto de estos elementos esta enfatizado por el juego de volúmenes y espacios vacios, constituido fundamentalmente por dos torres que albergan una el acceso a las oficinas del Instituto, y la otra el acceso al hotel y la confiteria. Formalmente las tres partes se componen de basamento y bloque. El basamento del edificio se comporta como un gran espacio escructurado por las torres, por el hueco de la galeria y por los porticos que sostienen el volumen del bloque.

Las oficinas generales del Instituto se desarrolian en grandes ambientes de doble orientación, divisible por medio de muebles. Un salón de doble altura se destina a sala de Directorio y Biblioteca.

La confiterfa tiene acceso directo desde la calle a traves de una terraza, vinculada también con el hall de acceso y con el salon de estar del hotel.

El hotel, tiene habitaciones de cinco tipos diferentes, que responden a 105 requerimientos previsibles.

Construcción: La estructura de hormigón se ha dejado a la vista. Las habitaciones del hotel: revocadas y pintadas de blanco, Casi la totalidad de los pisos son de mosaicos cerámicos de color blanco en las circulaciones de la galería, marrones en el podio del Instituto $y$ rojos en las habitaciones del hotel. 

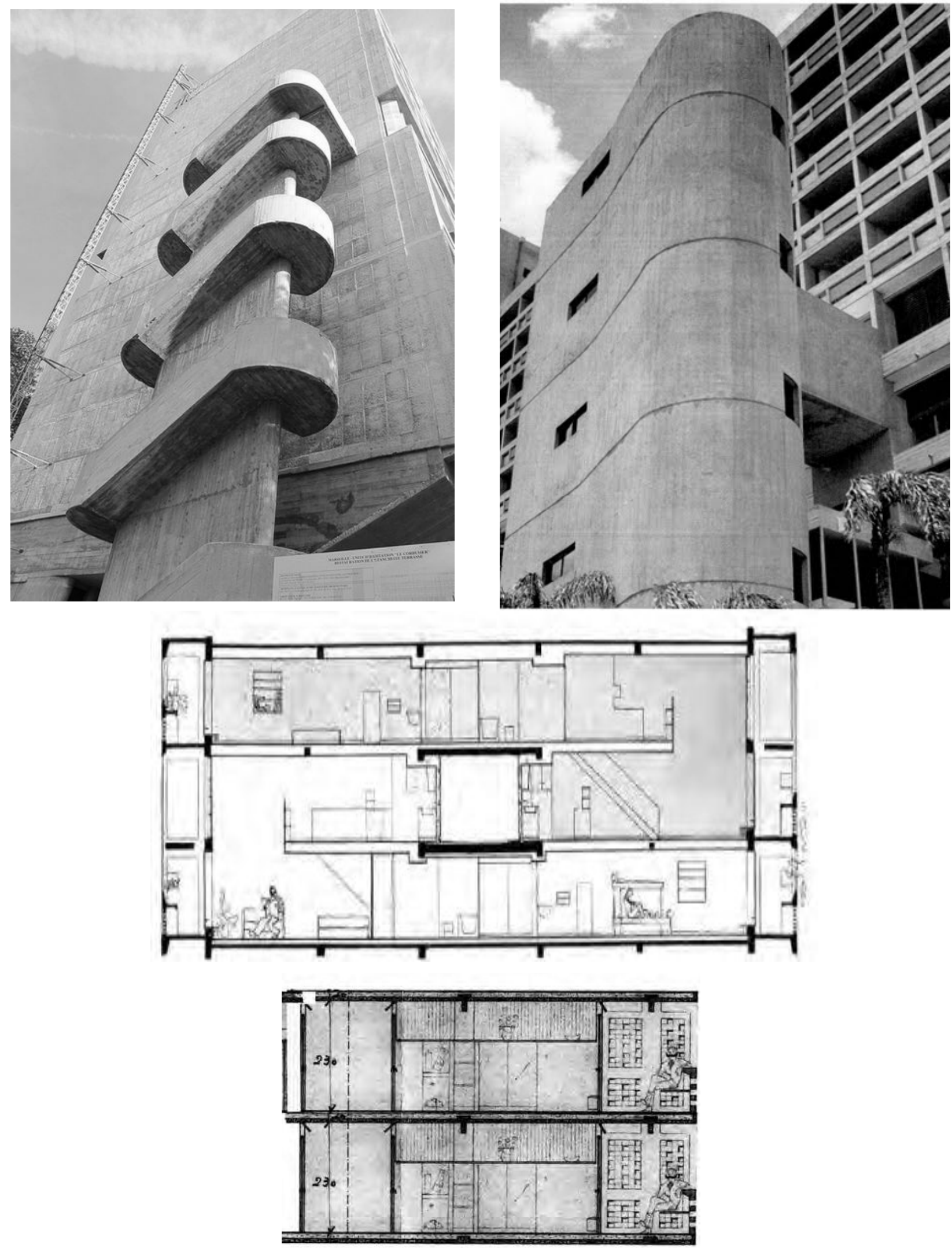

Comparación, en la columna izquierda Marsella de Le Corbusier; detalle de esclaera y corte por la célula de vivienda. A la derecha IPS 

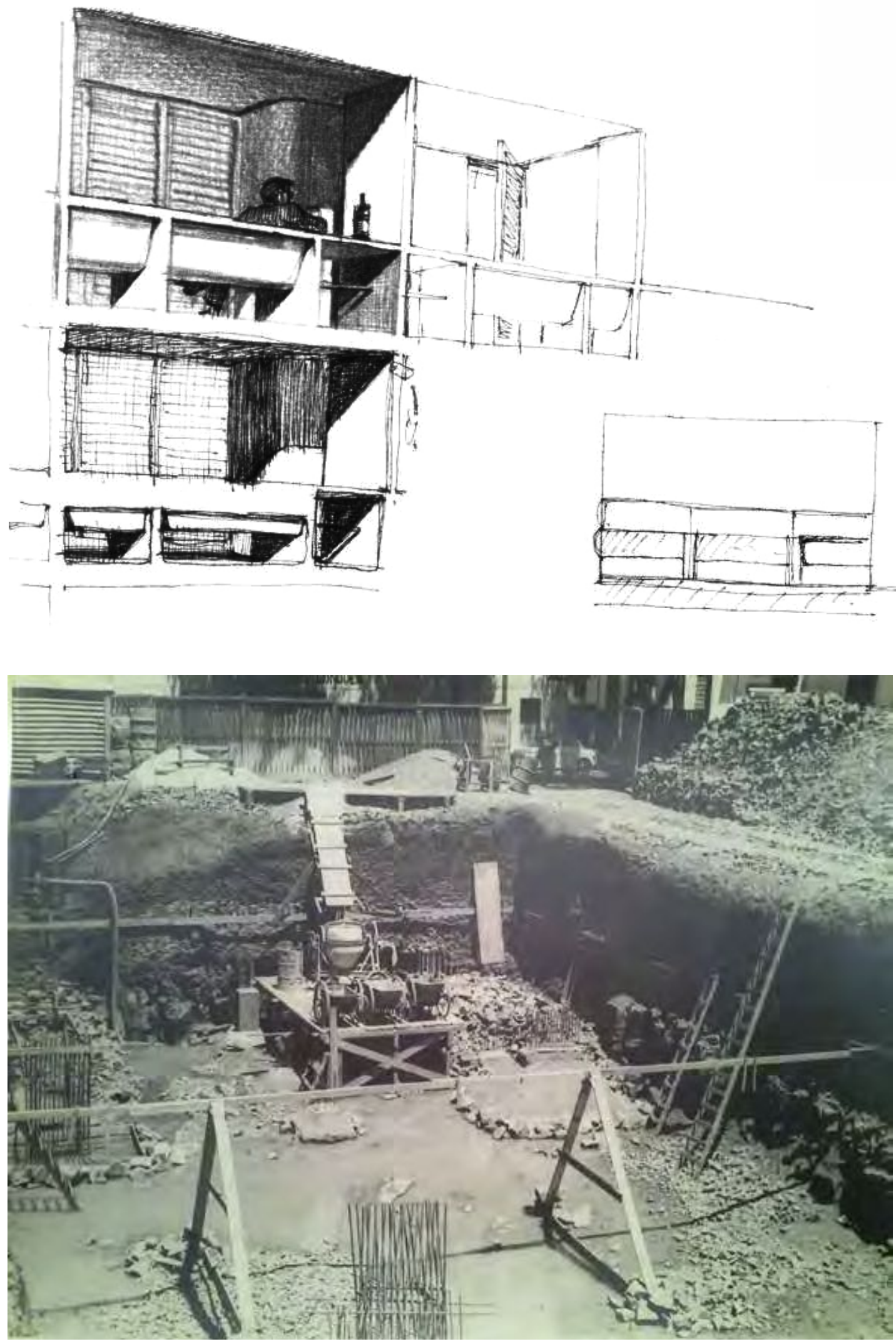

$127-128$ 

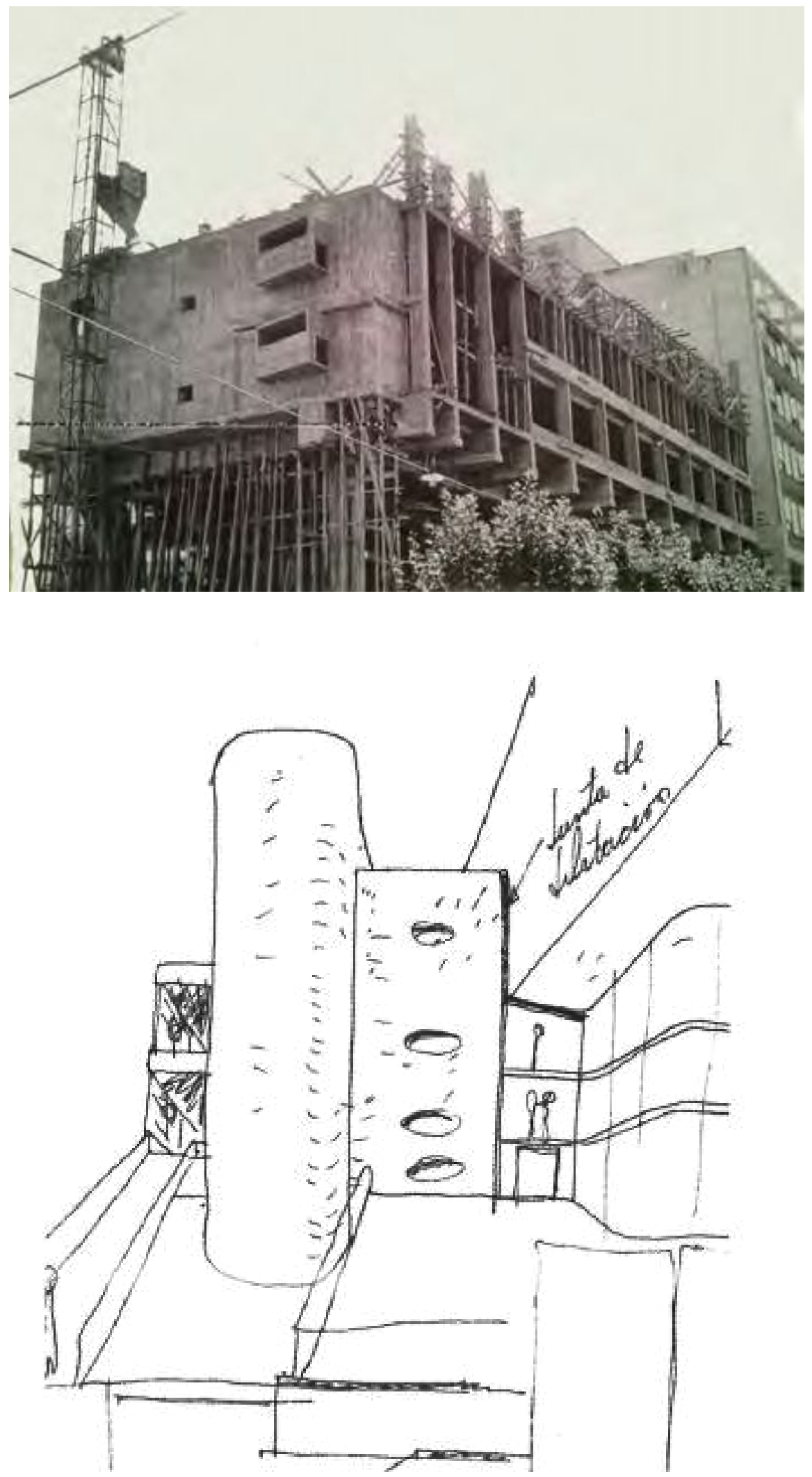


\section{Instituto de Previsión Social de la Ciudad de Posadas}

Perspectiva interior y exterior. Dibujo original del concurso
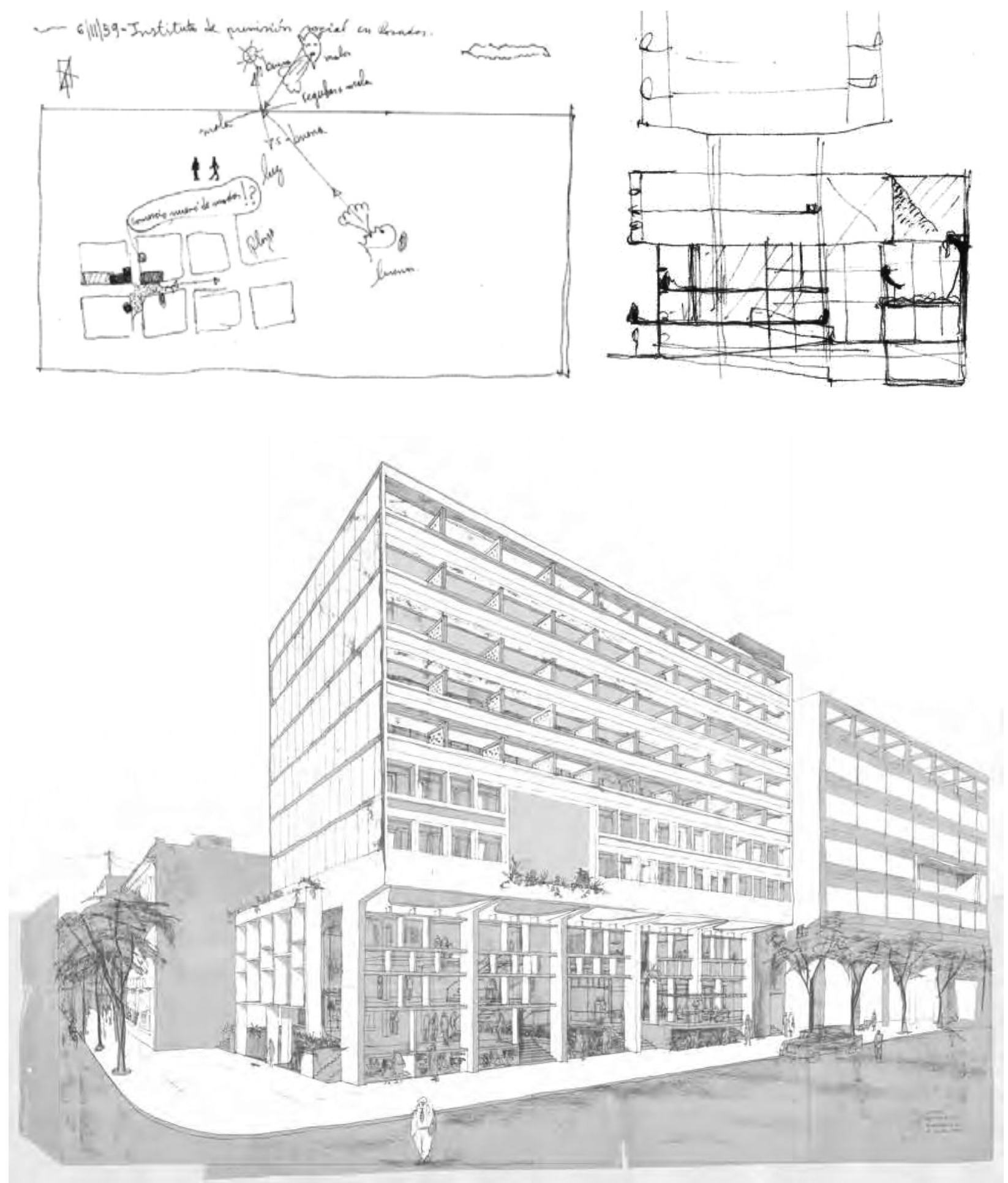

$131-132-133$ 
Instituto de Previsión Social de la Ciudad de Posadas

Planta baja, nivel de accesos. Panel original del concurso. Fotografía actual
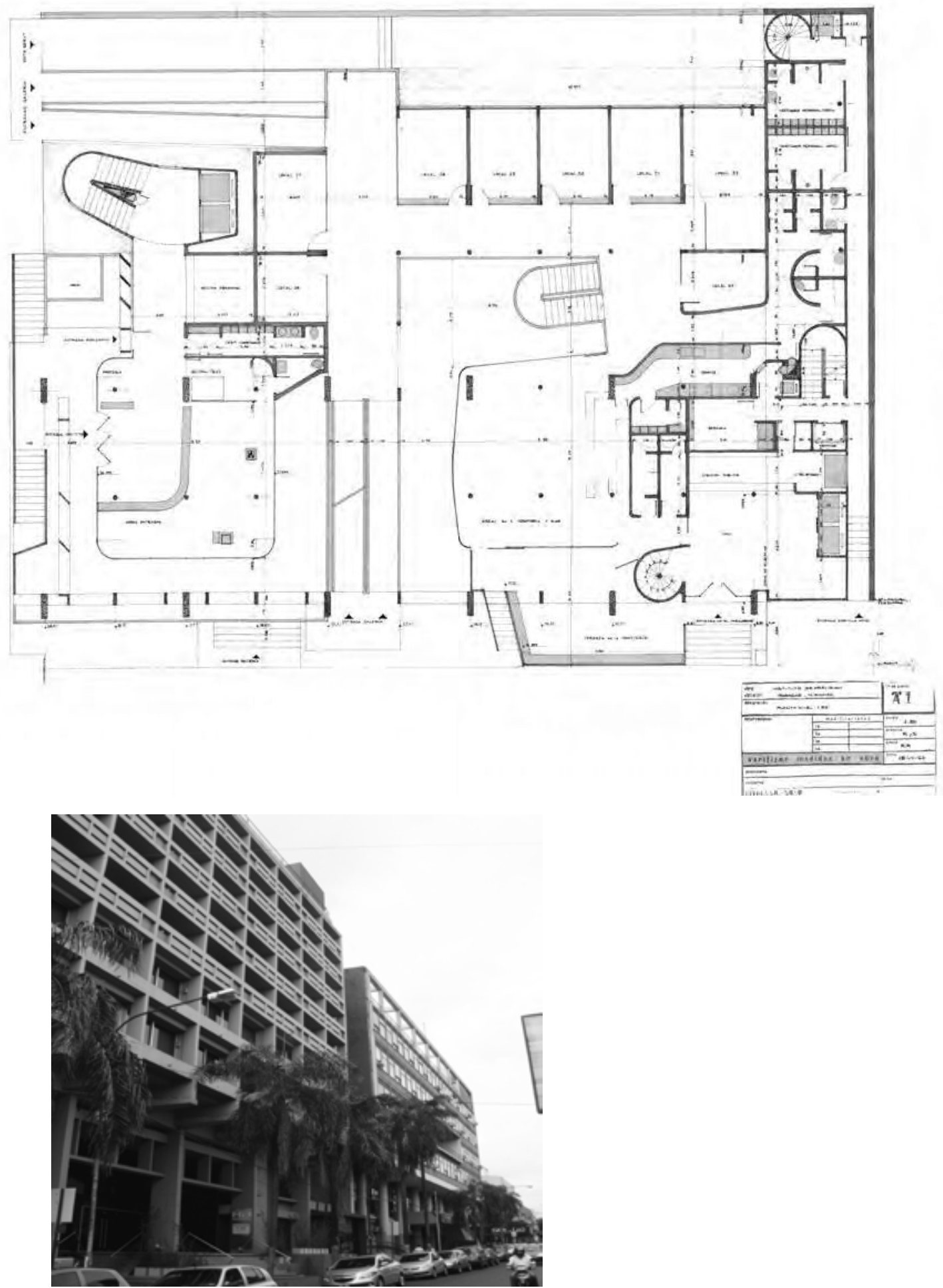
Instituto de Previsión Social de la Ciudad de Posadas

Corte y Planta nivel Hotel
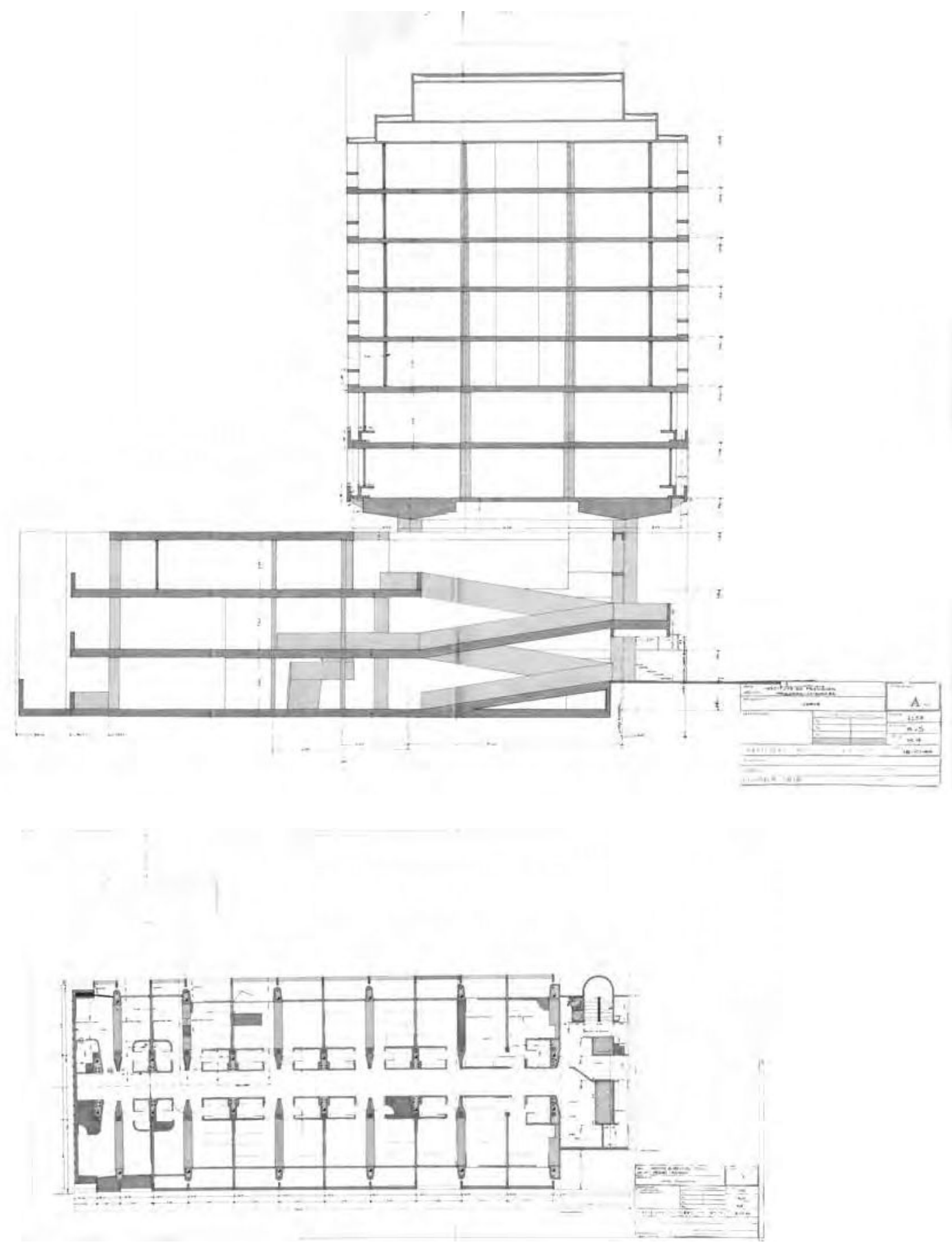

136- 137 

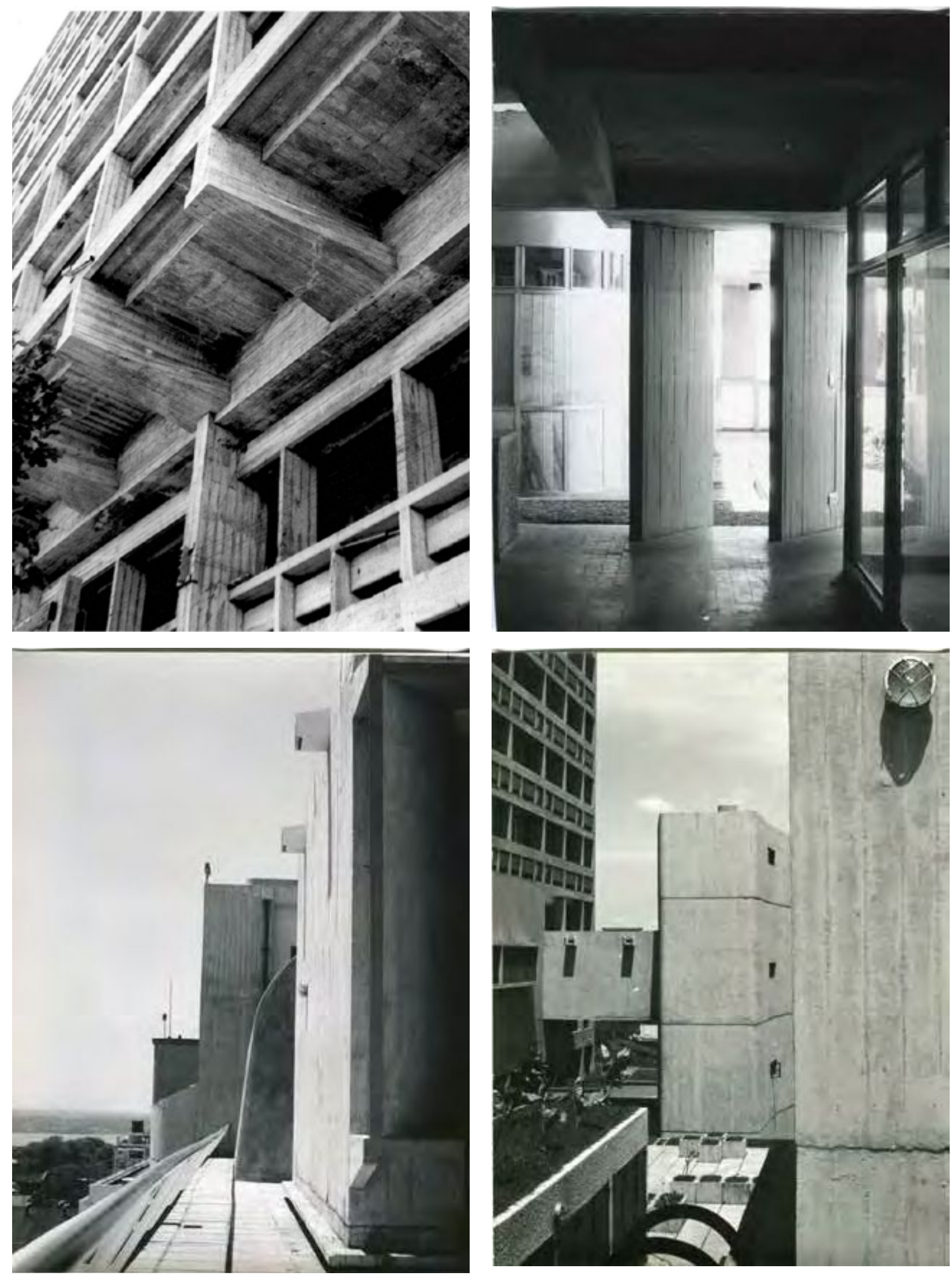

138 - 139 - $140-141$ 

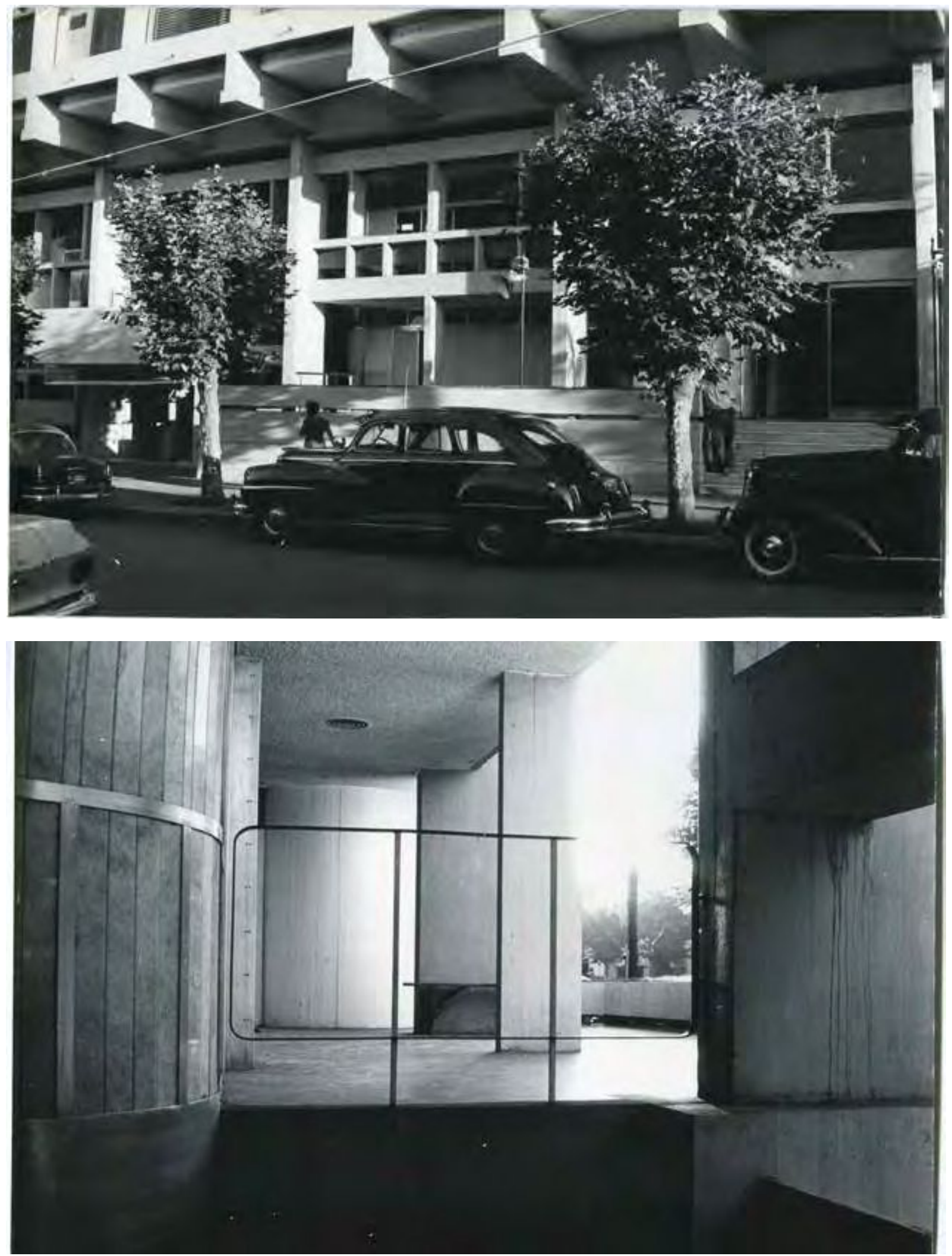

$142-143$ 

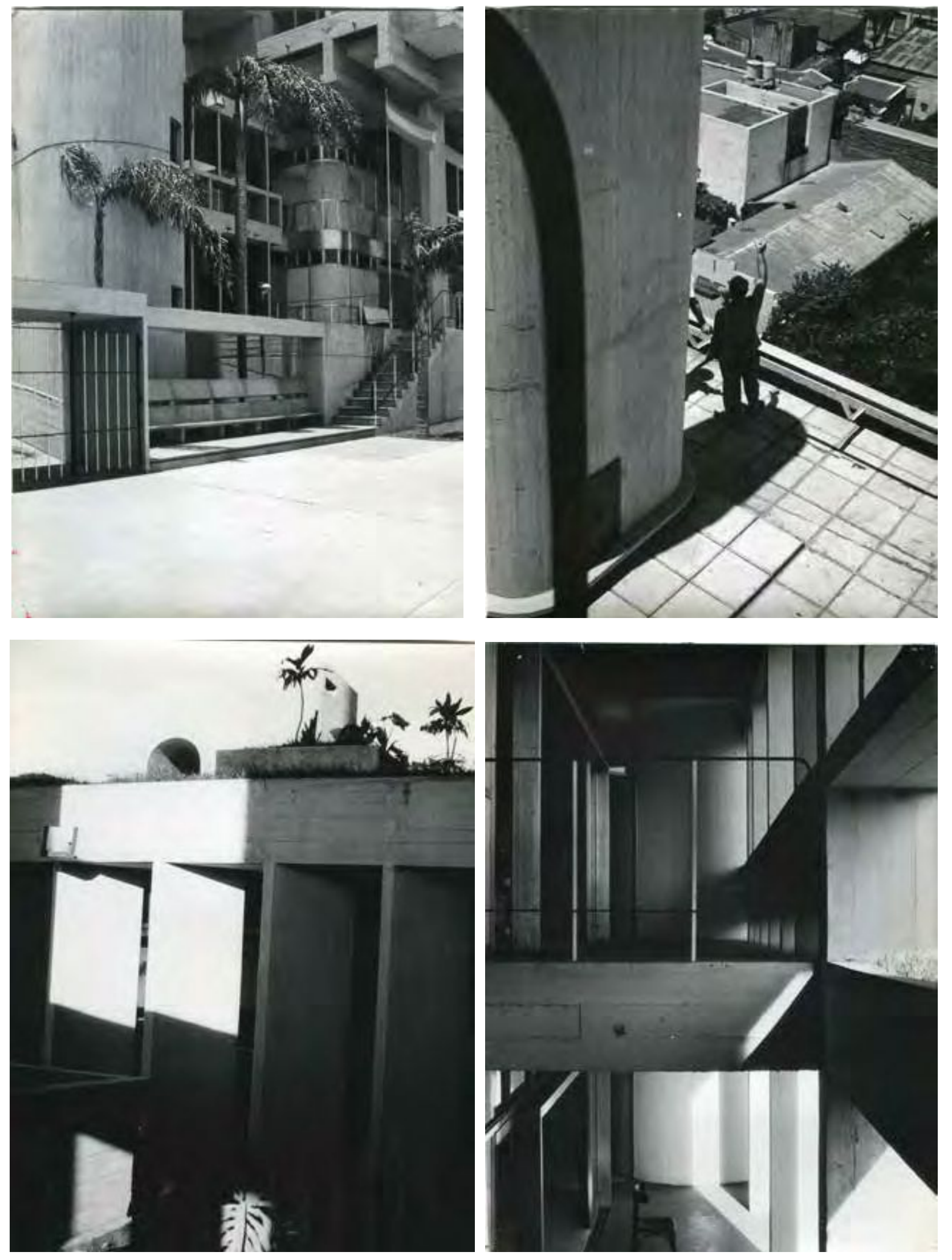

$144-145-146-147$ 


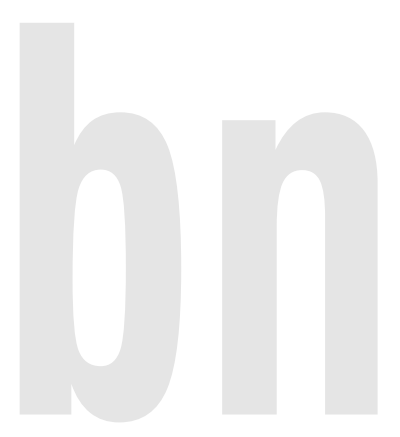

3er PREMIO, CONCURSO DE ANTEPROYECTOS PARA LA CONSTRUCCIÓN DEL EDIFICIO DE LA BIBLIOTECA NACIONAL

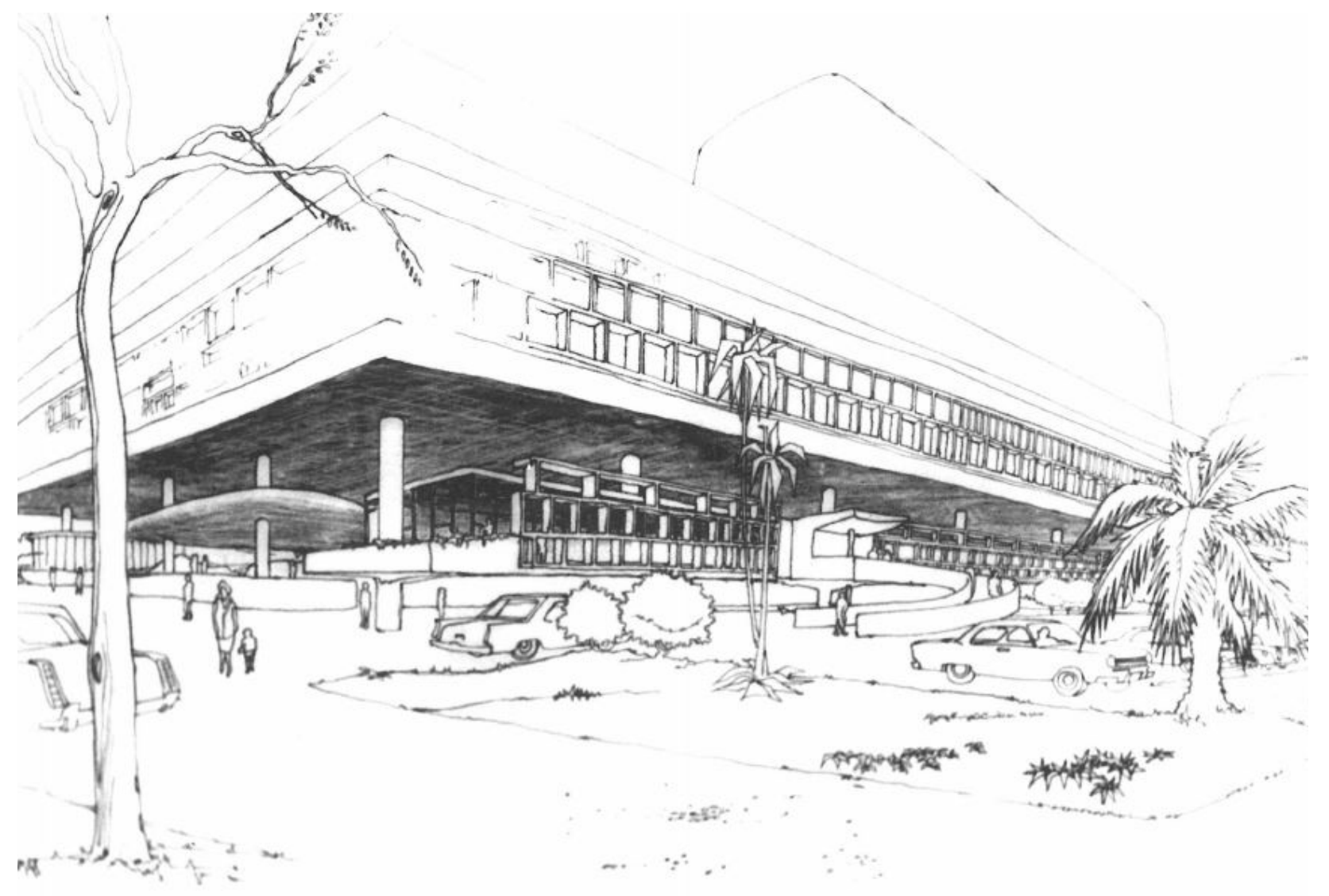




\section{Concurso para la Biblioteca Nacional}

3er Premio

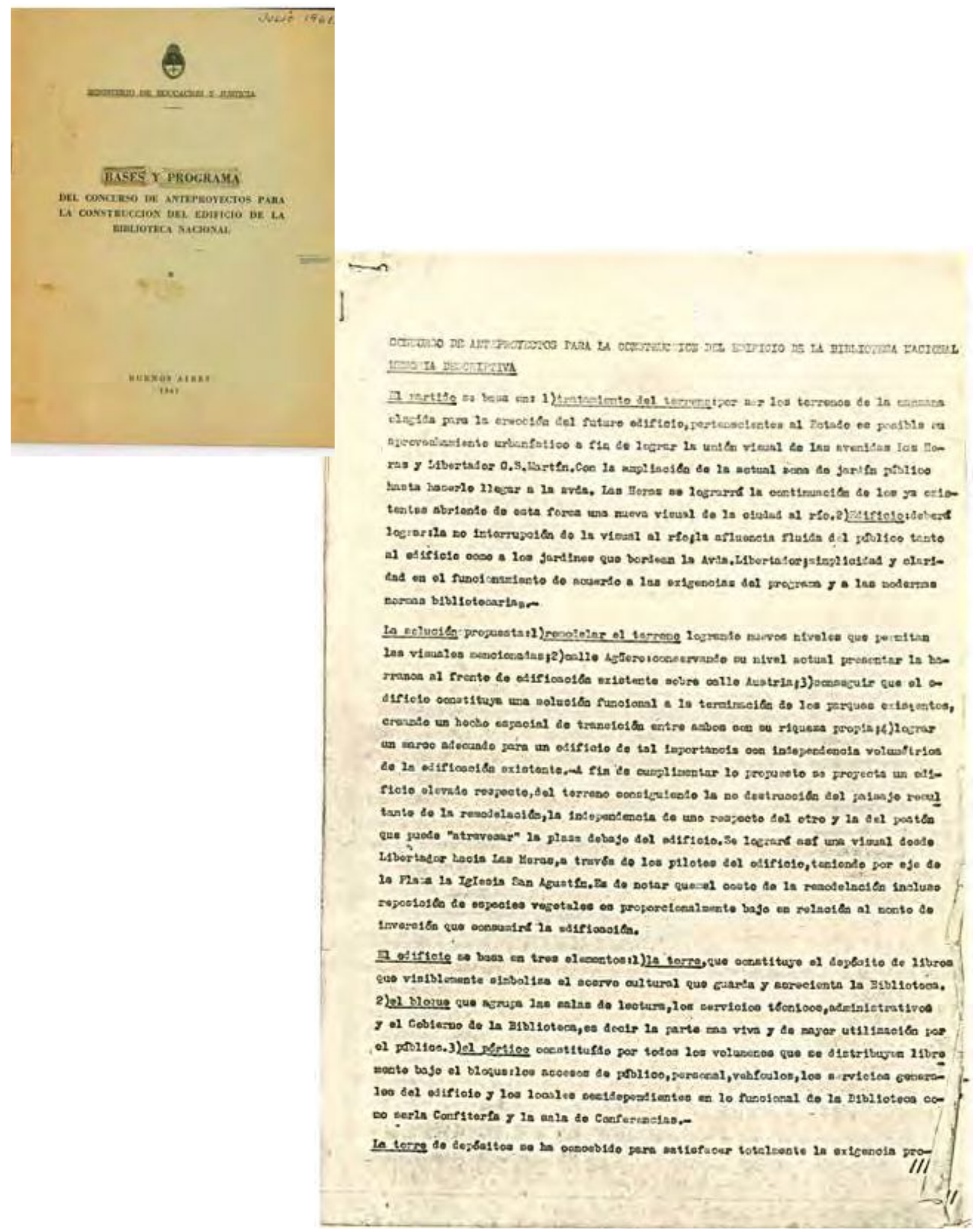

$148-149$ 


\section{Concurso para la Biblioteca Nacional}

3er Premio

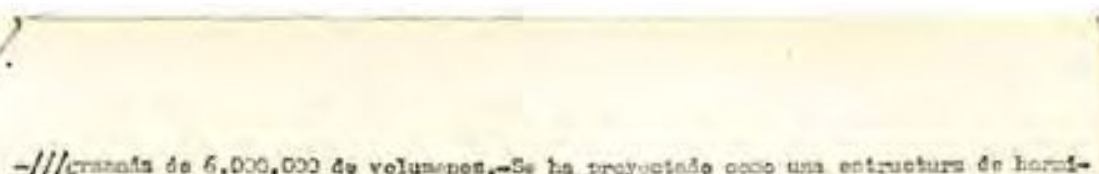

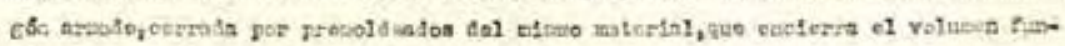

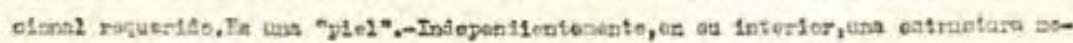

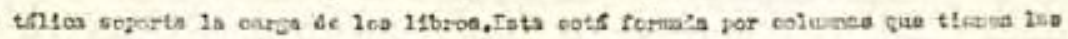

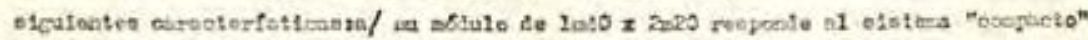

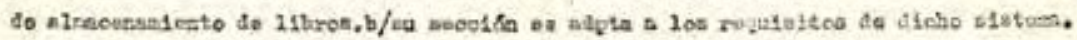

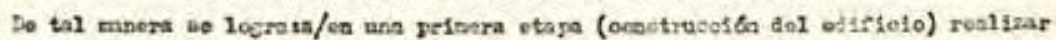

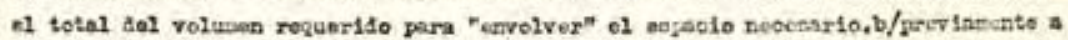

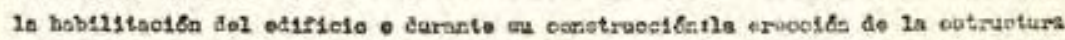

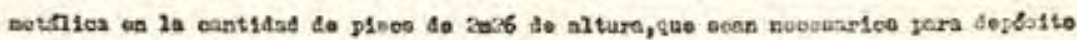

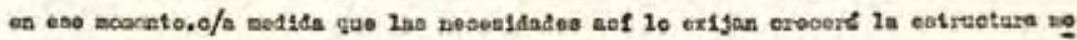

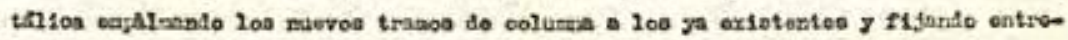

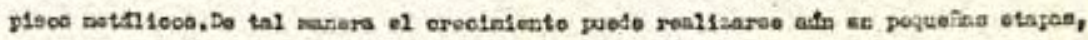

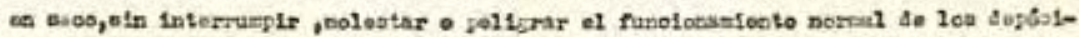

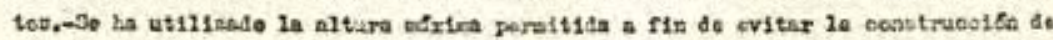

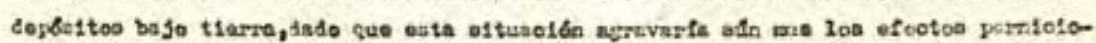

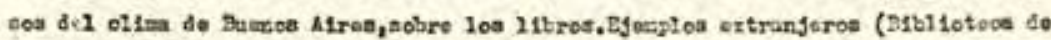

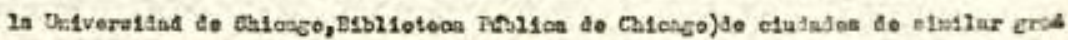

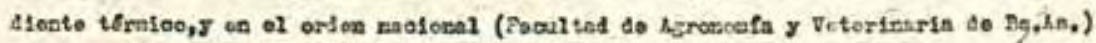
ceble deplatton bajo tlerra turleren sue aer elsaruretes, luaco de la postoea pirdila

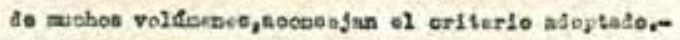

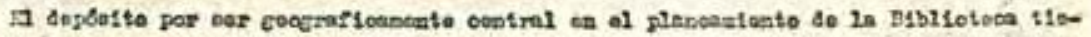

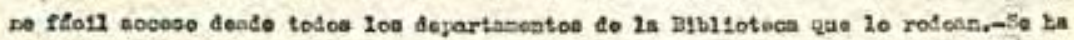

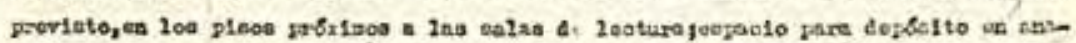

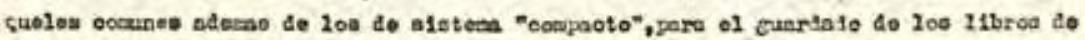

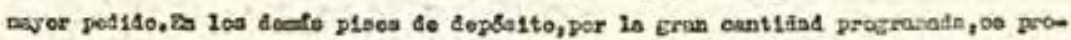
ven sangueloo roocjeoto".-

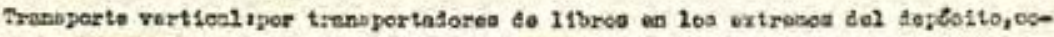

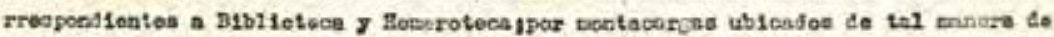

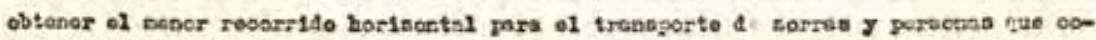

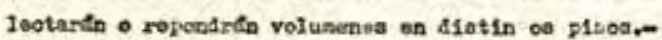

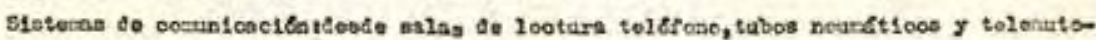

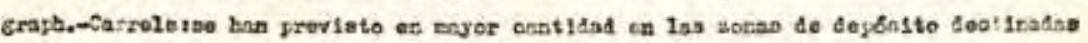

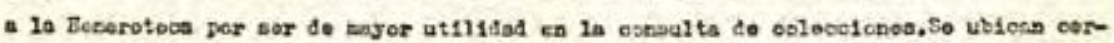

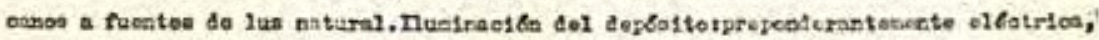

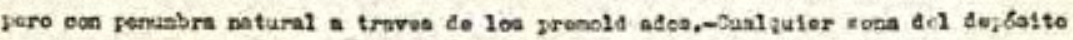

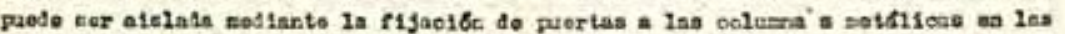
cabeceras do lao eeginas.-

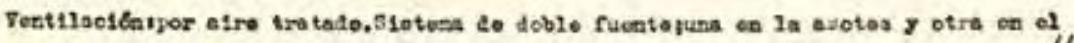




\section{Concurso para la Biblioteca Nacional}

3er Premio

-

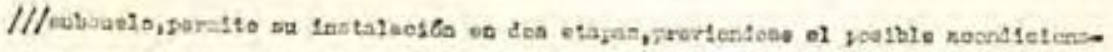

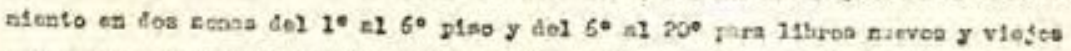

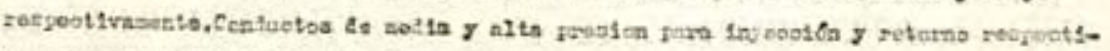

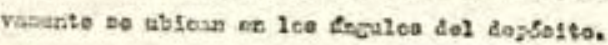

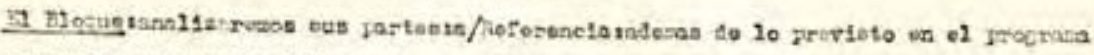

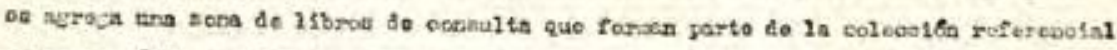

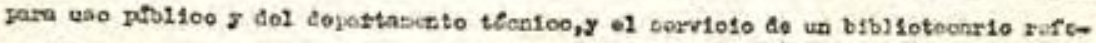

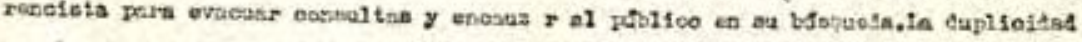

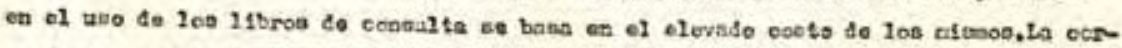

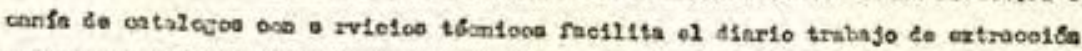

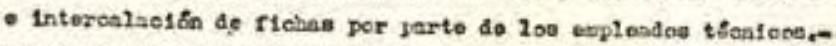

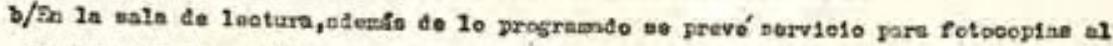
Invtunte $y$ hororiohan.

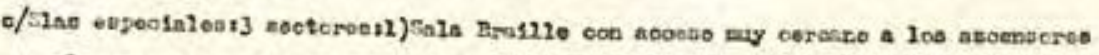

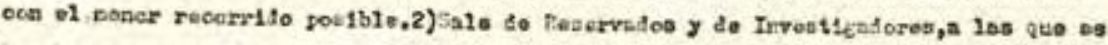

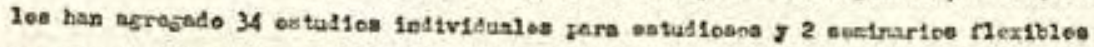

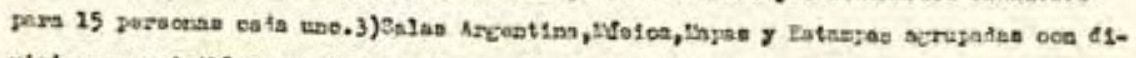

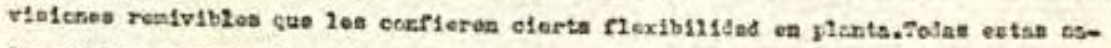
las, exoluyenioa Prasile eetin previstas para eu ruturo areolefonto que lleva a to-

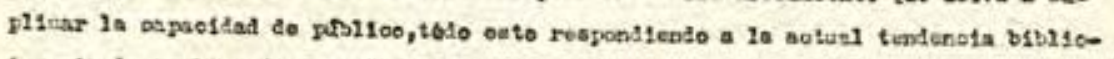

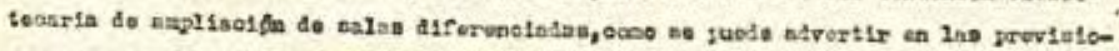

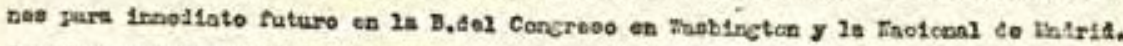

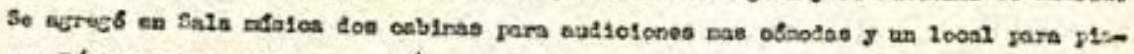

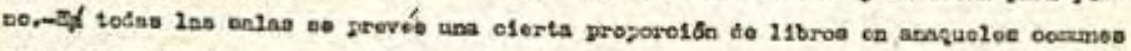
oan noceso direeto o ocotrolato por al pobileo.

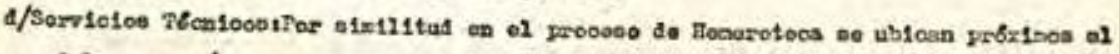

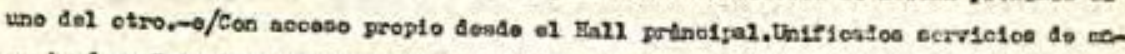

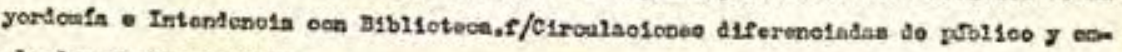
pleados on sena zeotura.

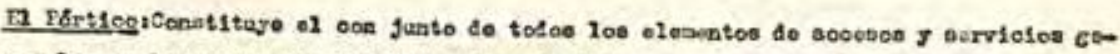

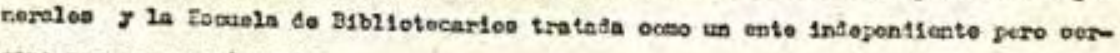
cano por rasunes docentoe,- 
Concurso para la Biblioteca Nacional
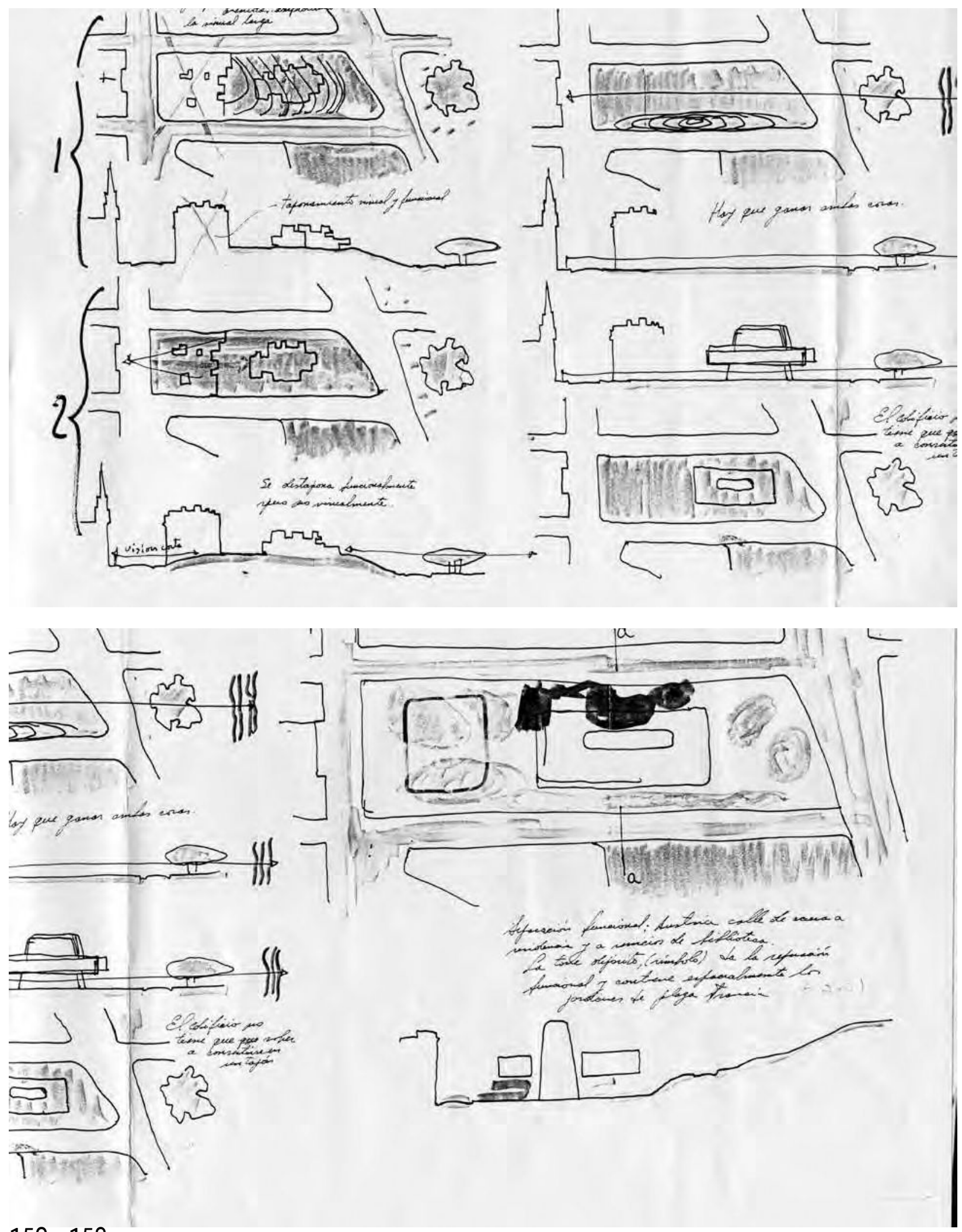

$152-153$ 
Concurso para la Biblioteca Nacional

3er Premio
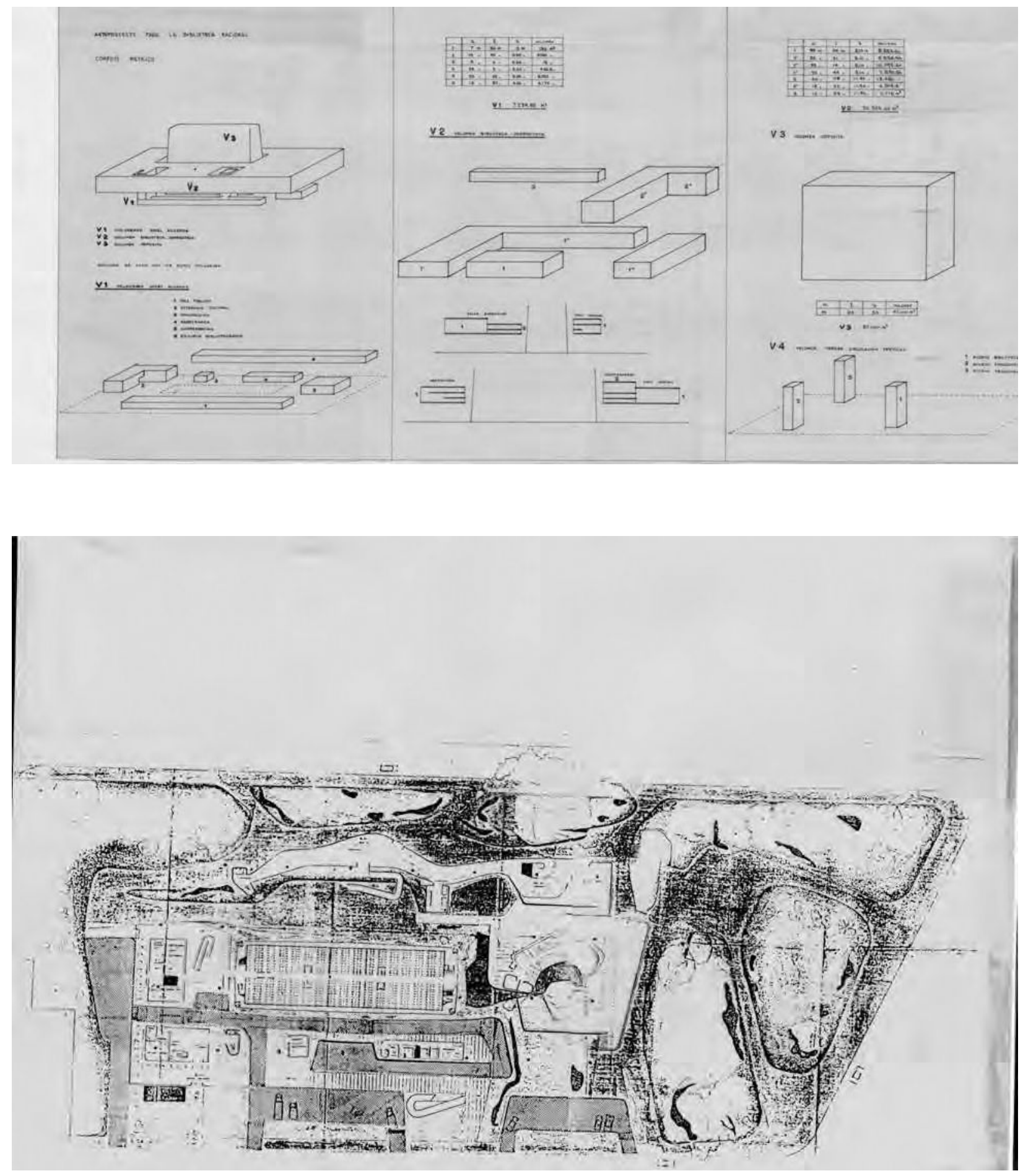


\section{Concurso para la Biblioteca Nacional}

\section{3er Premio}
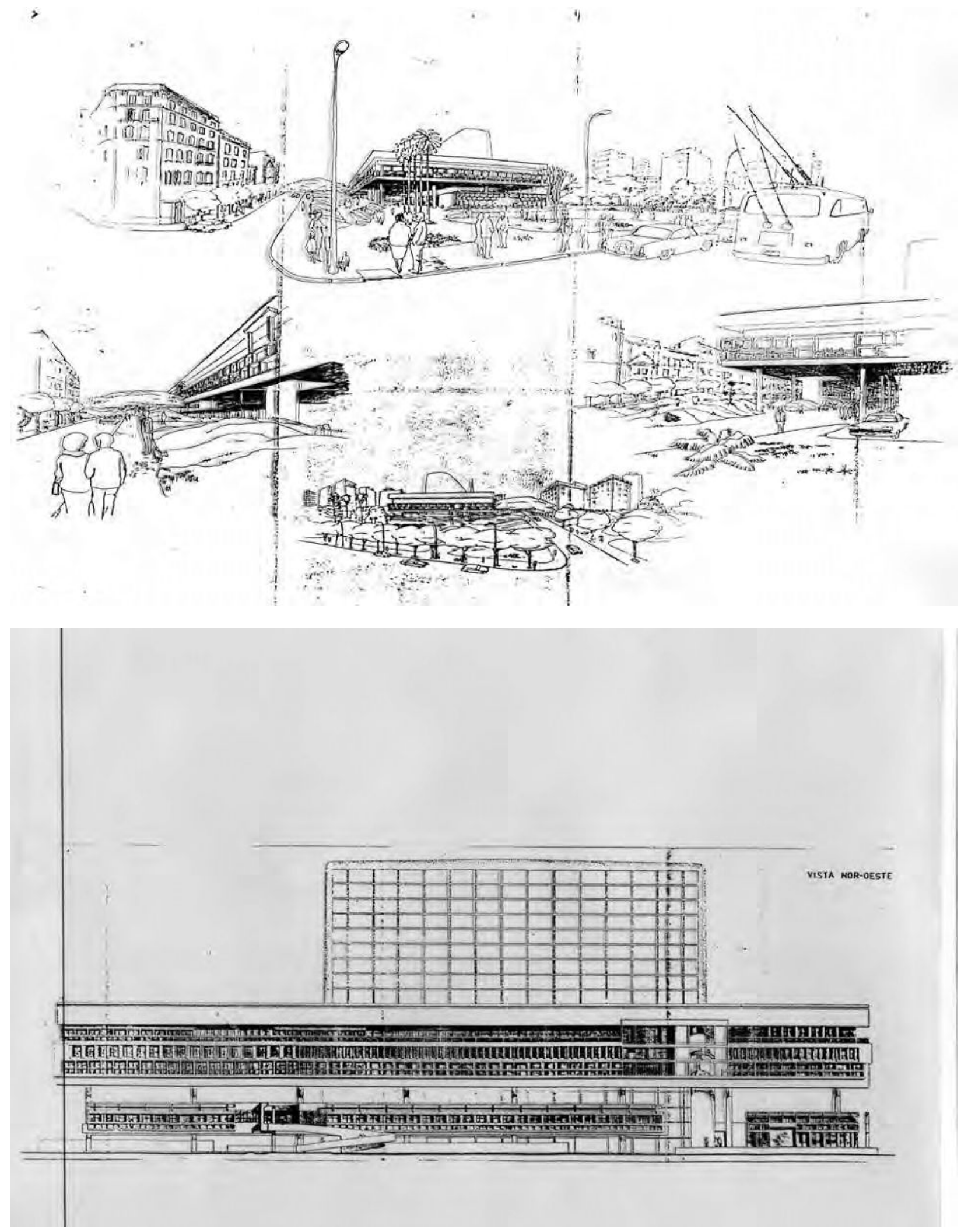

$156-157$ 


\title{
Concurso para la Biblioteca Nacional
}

\author{
3er Premio
}
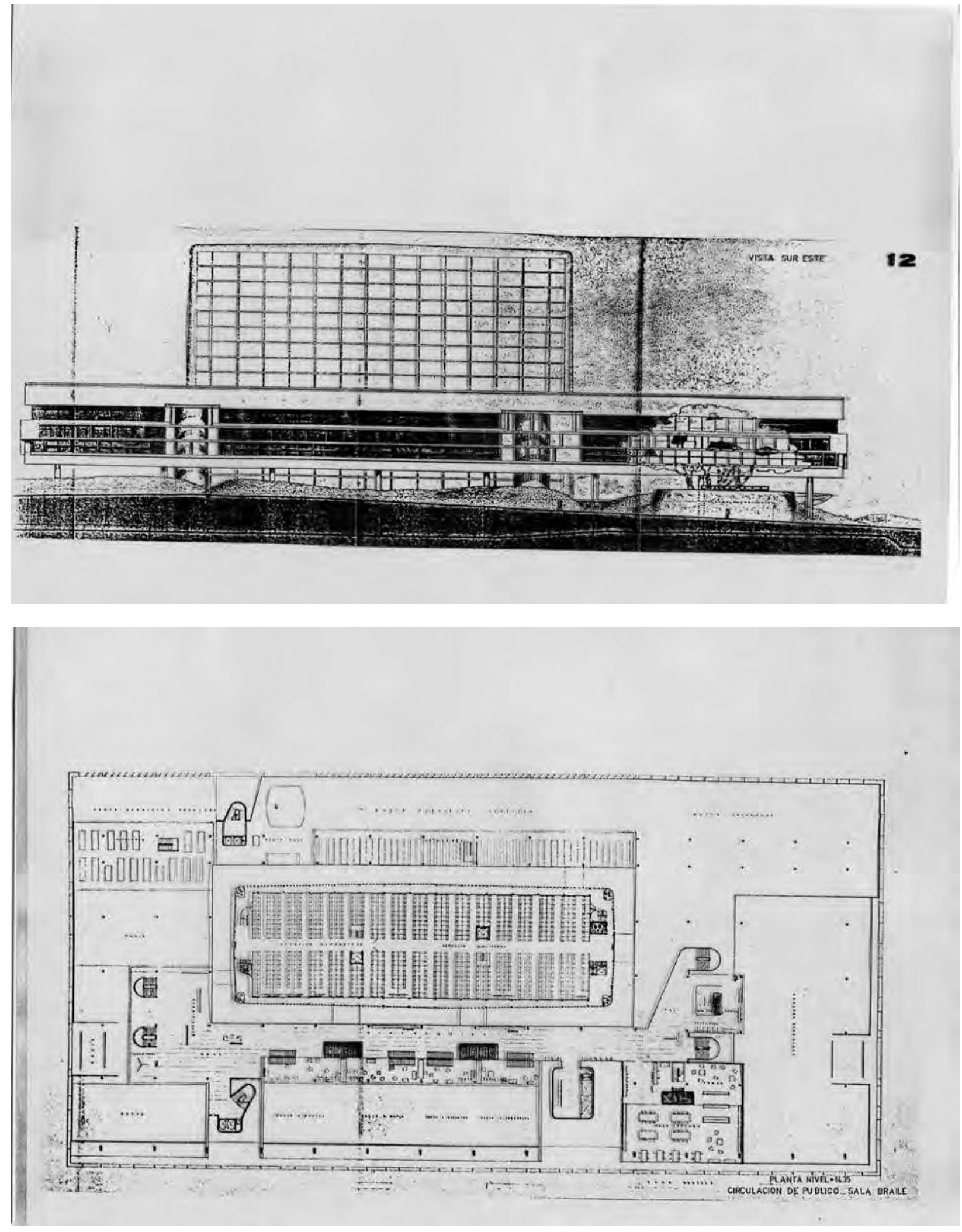


\title{
Concurso para la Biblioteca Nacional
}

\author{
3er Premio
}
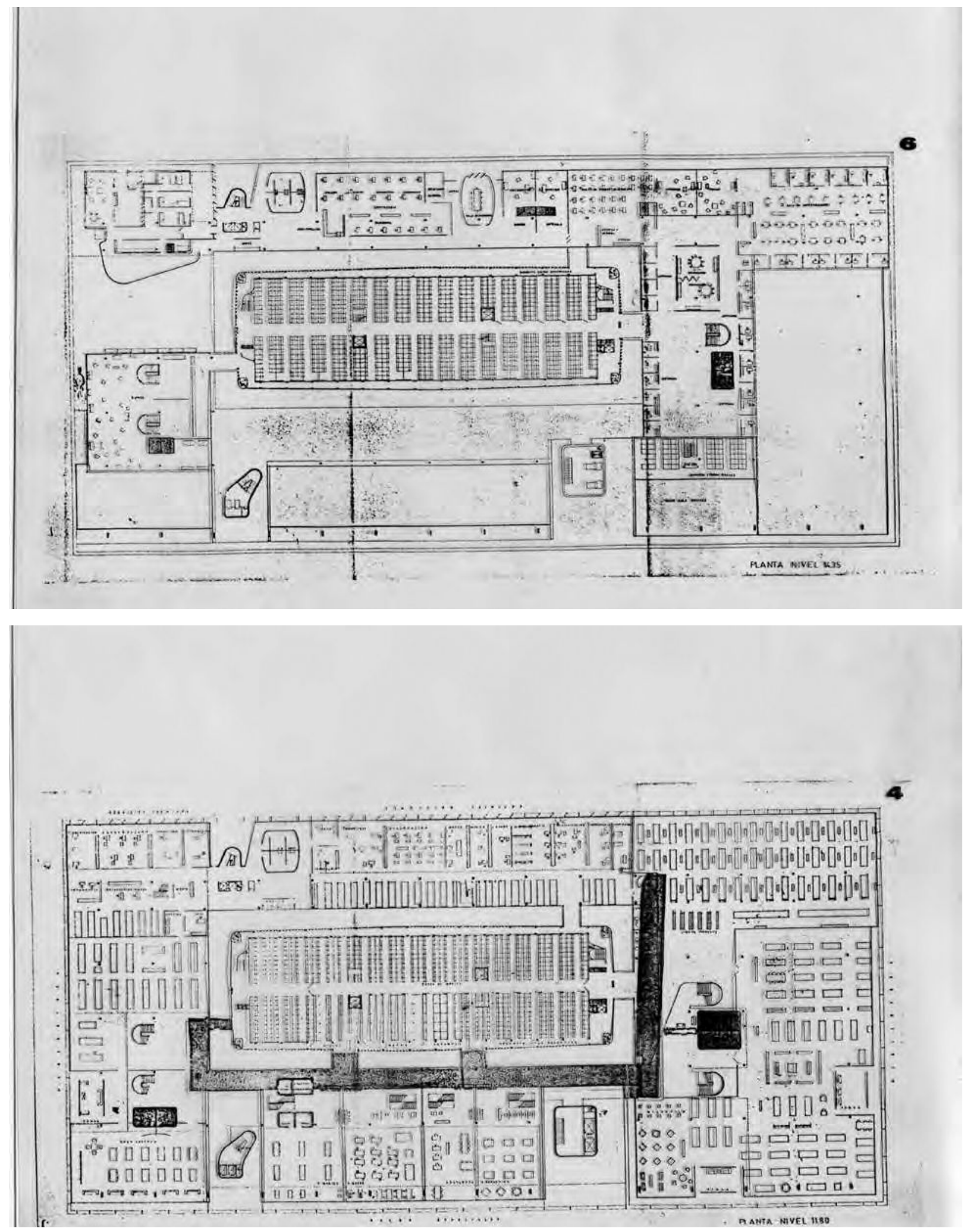

$160-161$ 
Concurso para la Biblioteca Nacional

3er Premio
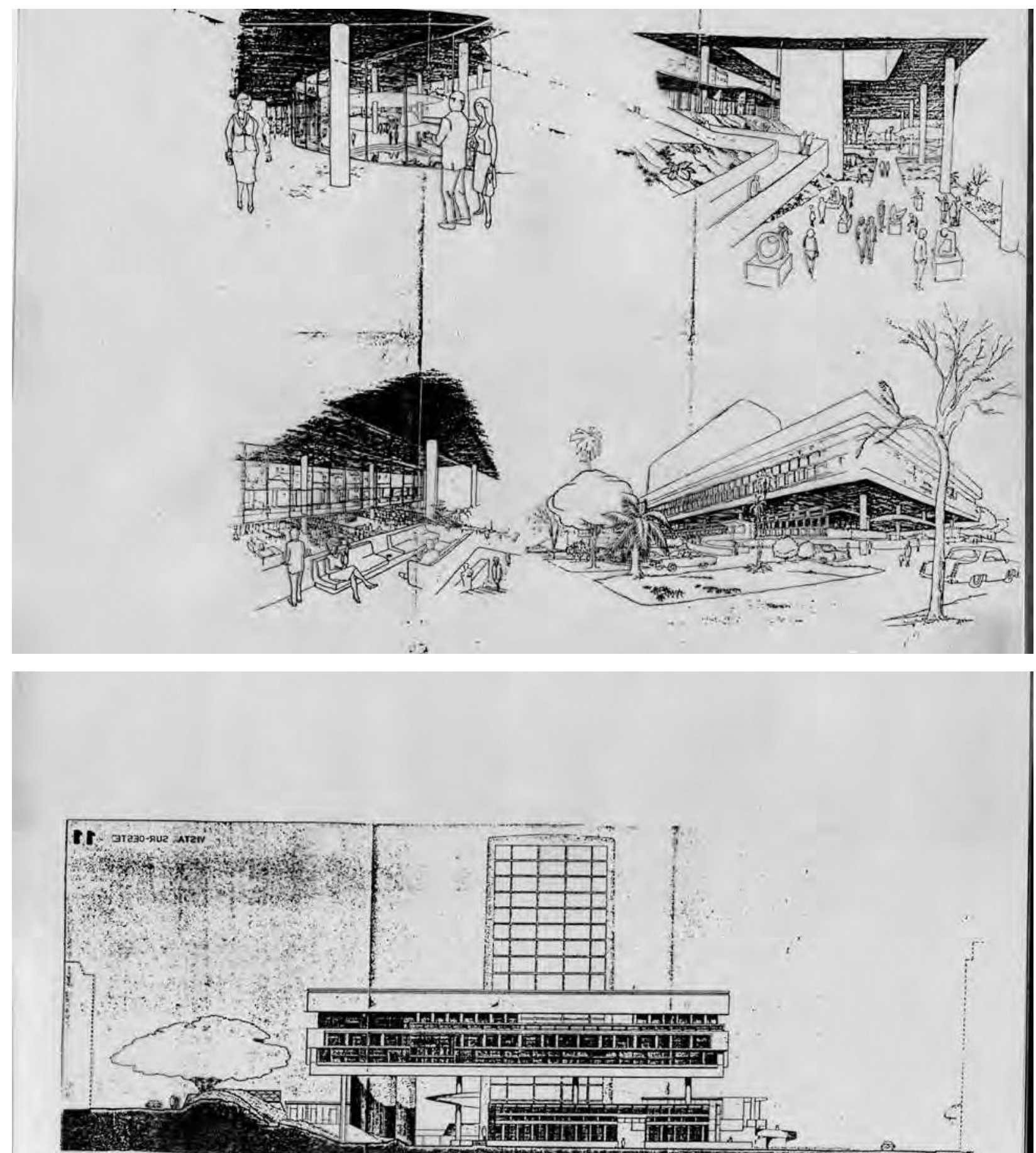
Concurso para la Biblioteca Nacional

3er Premio
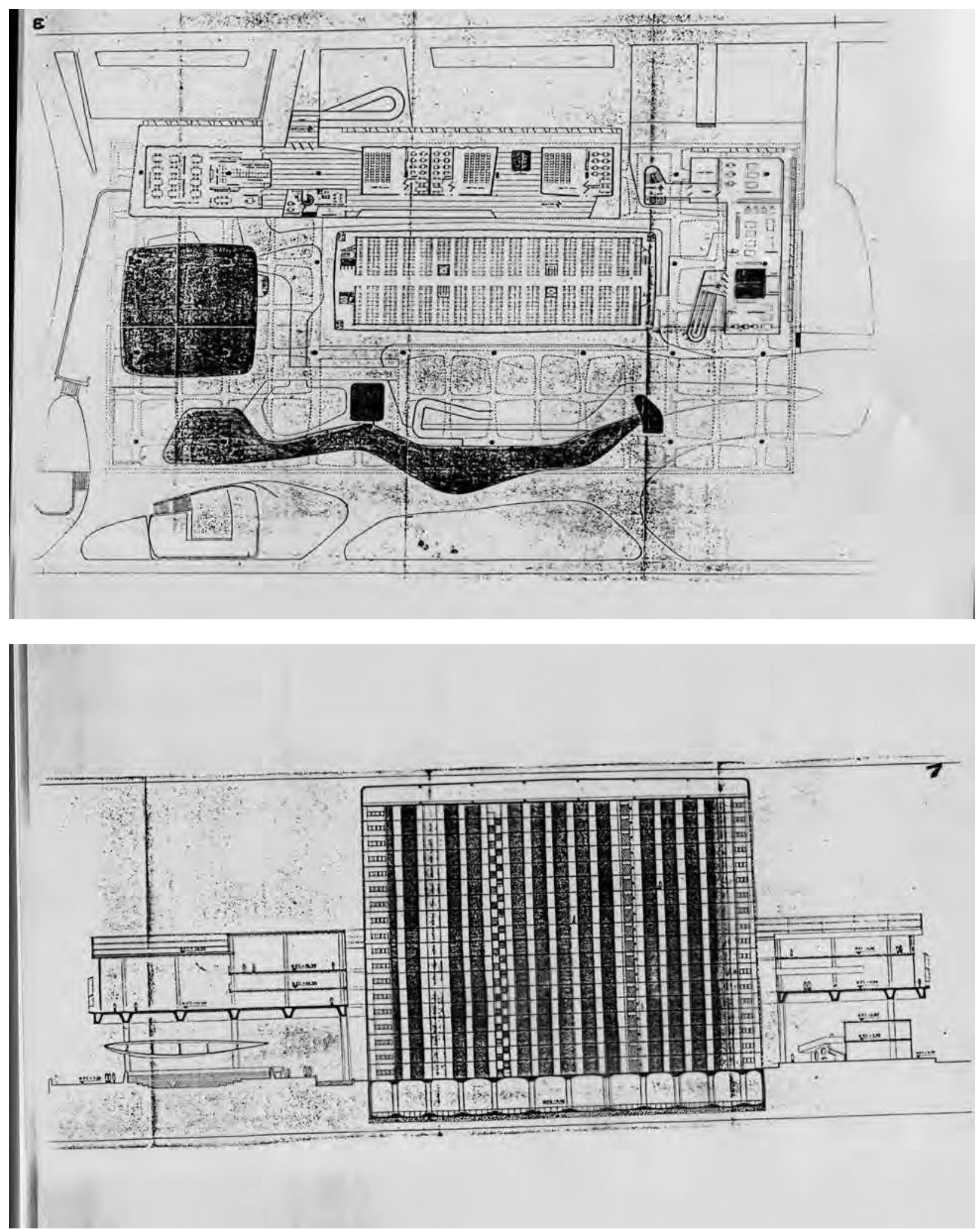

$164-165$ 
Concurso para la Biblioteca Nacional

3er Premio
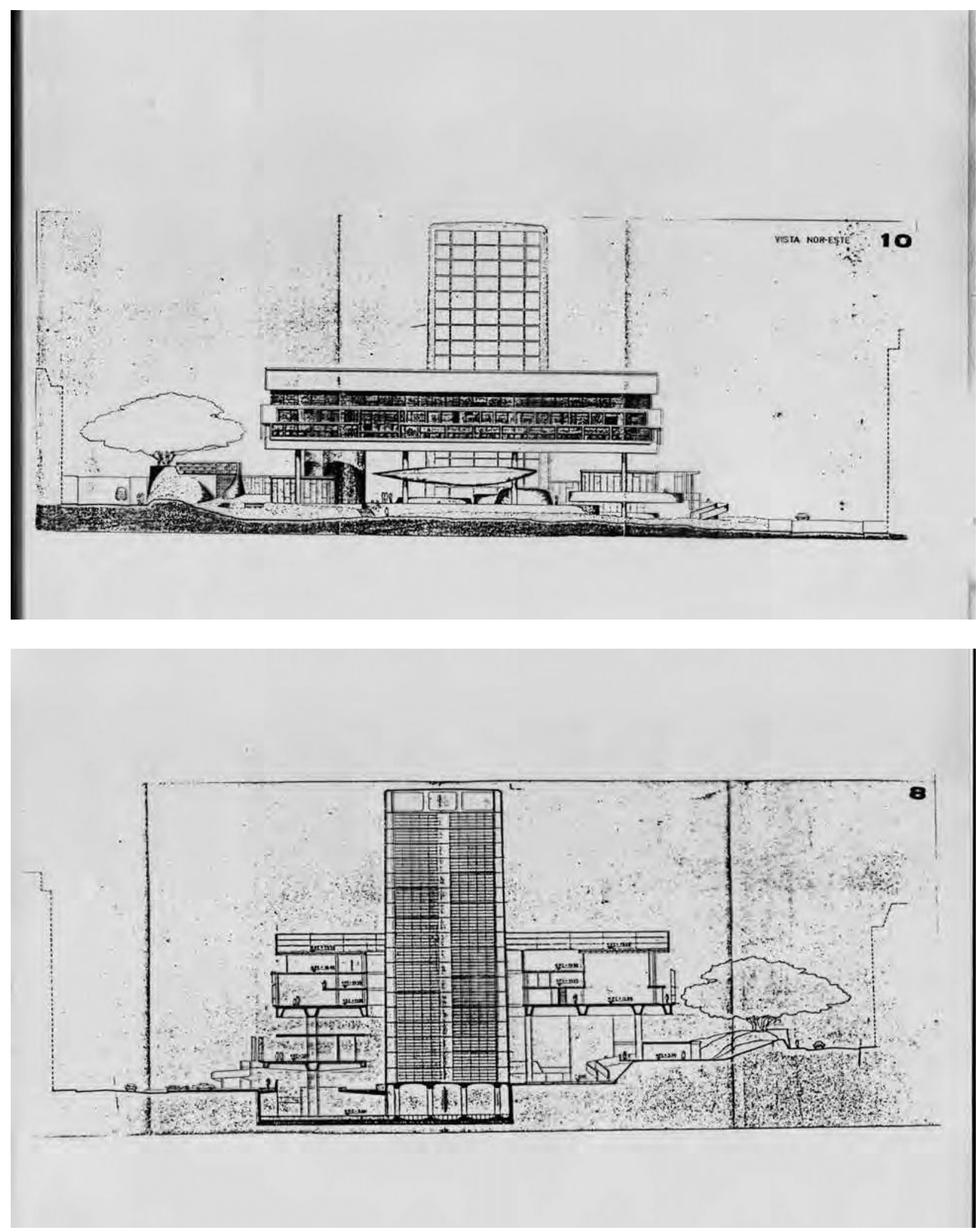

$166-167$ 


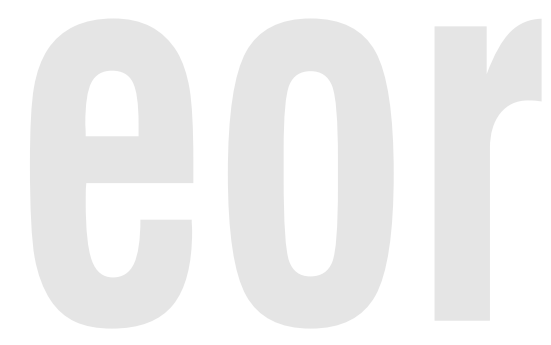

ESTACIÓN TERMINAL DE ÓMNIBUS DE RESISTENCIA CHACO

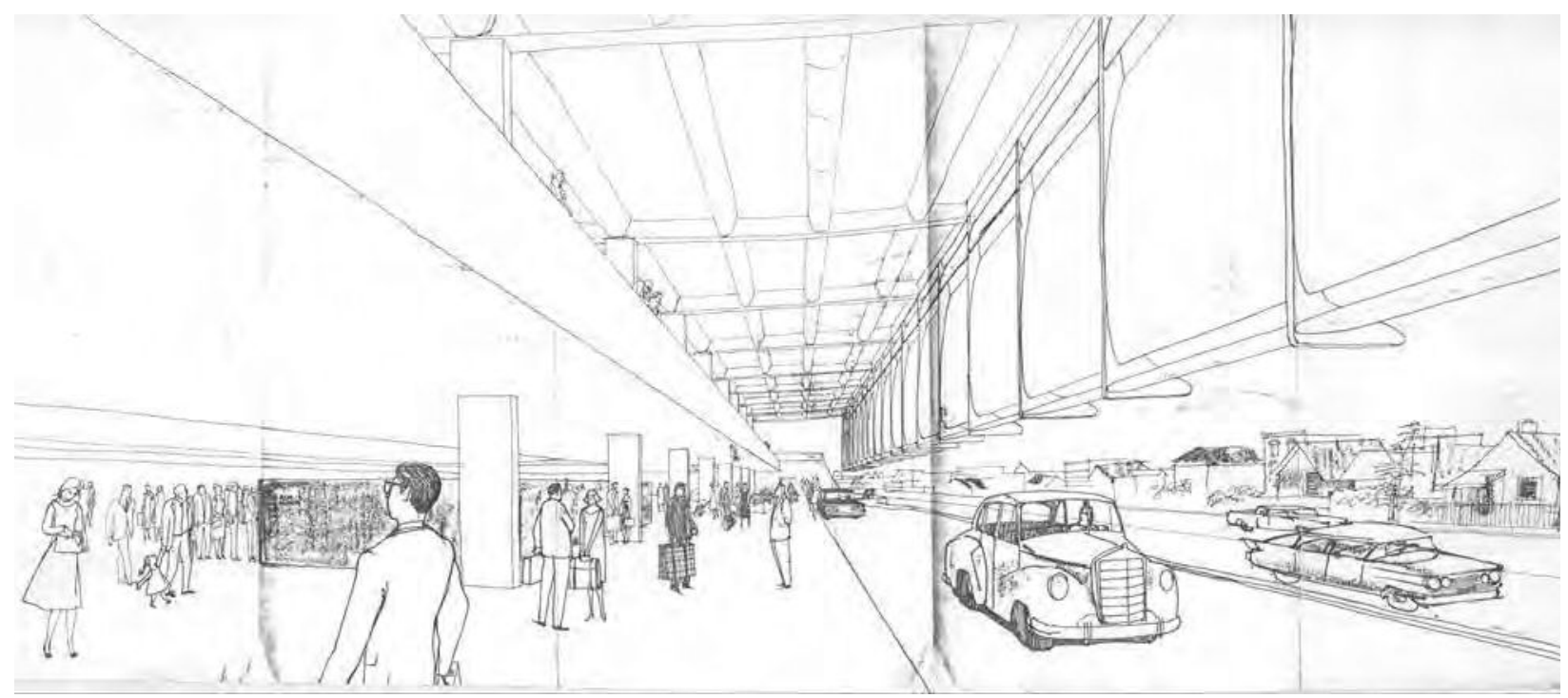




\section{Concurso para la Terminal de Ómnibus de Resistencia, Chaco}

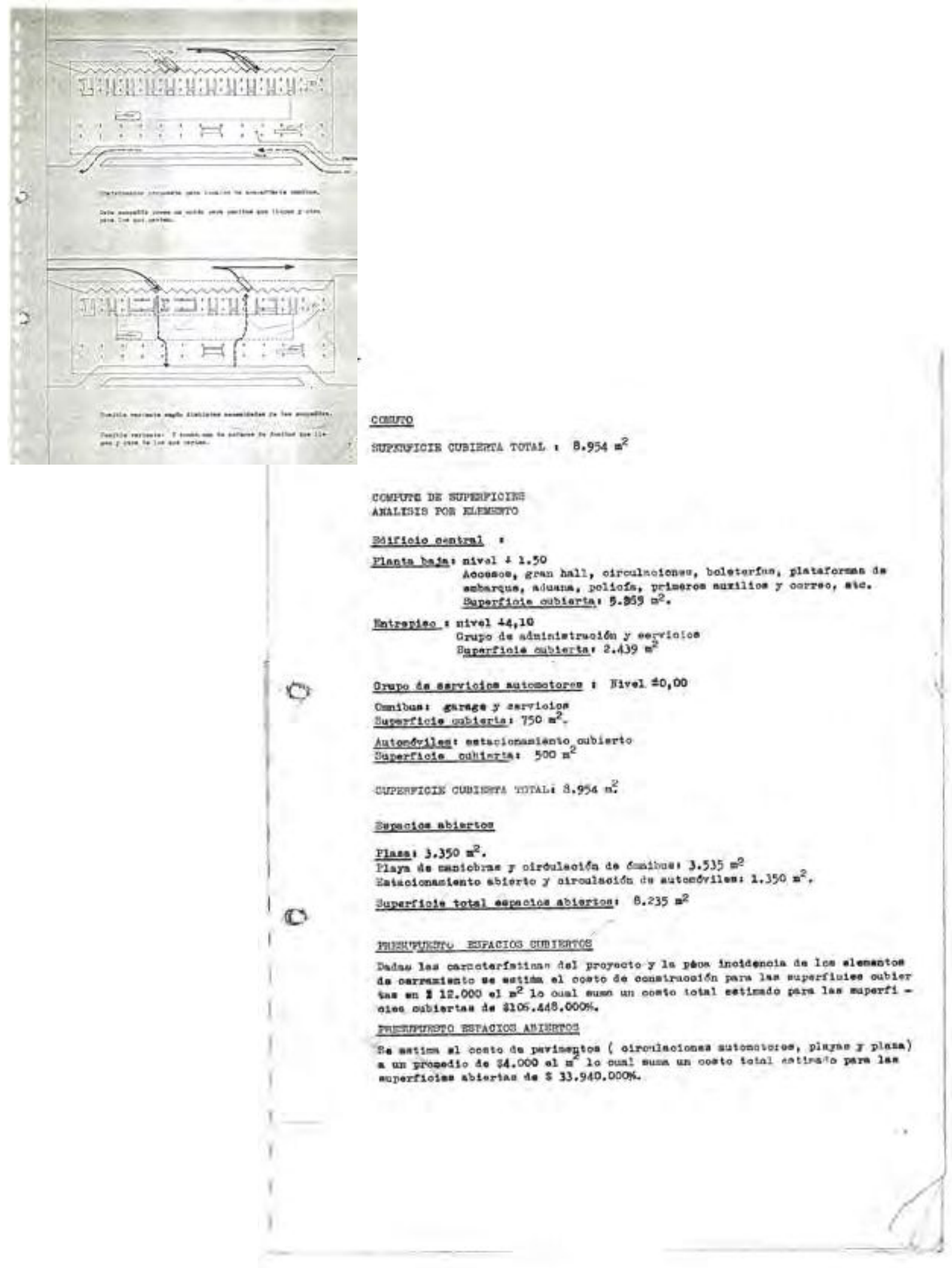




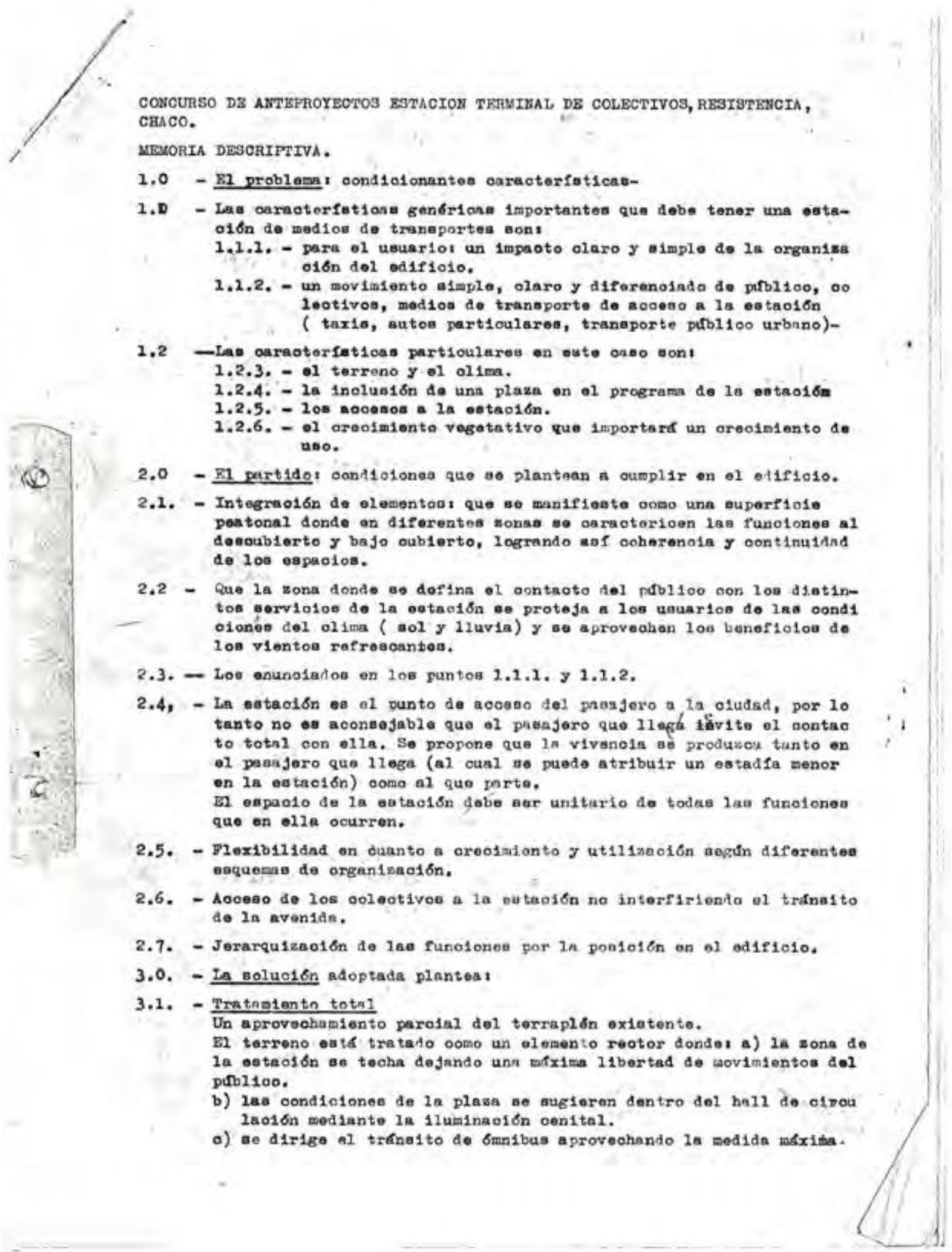


3.1. - d) el estabionimiento de aintes de publioo y la sona be aerviolo de loe oolootivos oe zonlelcan en los extreson del terreno exolu gendolos do laeviata $y$ alejendolos del pofblioo yo que sua fun alones difieron notamente de lap que ocurren on la sataolon.

-) al abladoiea oontinuo on todo lo pentonal aoentuando la unidad.

3.2. - el ed1f1010 opnulate on une plants de sooeso de publioo $y$ aoleotivoa por los lados enfrentados $y$ un entrpiao. Contral se forma un

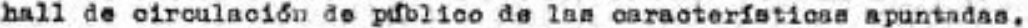

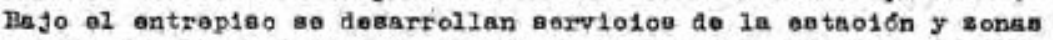
do espers. Fin el ontrepluo diatintoo loonlos de negoolos, rostaurante- confiteria, bibllateos $y$ aons administrstiva.

Fn la planta baja axiaten 208 aerviolos de atemo16́n milu direots.

3.3. - Oxgnnirac18n de andanes (var GrAP10o) - Se plantion unn sons intermodia entre los frmibue $y$ el eren hall que oorresponfe a los sorvi olos direntos que preatan las companfass reoepolón de equipajes, Informaojon, enoomiondar, sto, Adesía una zonk to eapera que no Interflera ol movimiento del gran ha11.

Anf miamo las comparisas ouentan con una sona on el entrepino para las sotividades adminietrativas ( oon atencion de pitolico). Eatas d dou sonss de 1 as a ampafifas ronntarán ach tel6fono interna y monteaxpedientee.

Fate alatema permite divoraas organitaciones

- una separajón del publioo de la zona de scoeso do pasajeros.

- Aocesony partida de ooleotivoa frente a la ofloina de la compeGIa oon reoopolón $y$ ontrogn do aigul jajas, eto.

- que slgunos andenes ae dentinar ablo a bolectivoa que llegran $y$ otrob a Ia gue parten a f'in de oanaliasr la ofroulacion do públ10o on ol hall.

- Aistintoe tamsfion dadicadoa a ceda oompafía aogún los requeri mientos de uso de andenor do gada uno.

3.4. - MAuans- a ella se dodioan dos andenea oompleantarioa.oon las conojguientes 1nofalsciones.

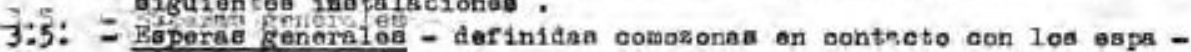
aloo al aire libra.

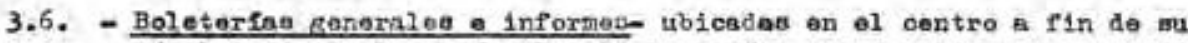

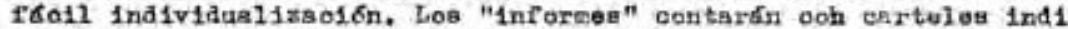
oaderes de morimiento de ooleotivos.

3.7. - So ub1 nan on las dos plantas todou lon localen de servioio je asn1

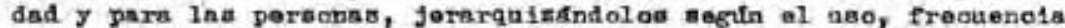
$y$ ounliad. ABI por oferplo el bar de ubo rबpido o Informal se ub1 on on in miams planta que $10 \mathrm{a}$ andeneat on anmbio ol reatalarnnt par Bus arsotorfstions se aleja del movimiento dul jufblioo.

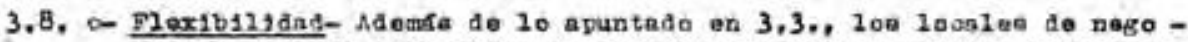

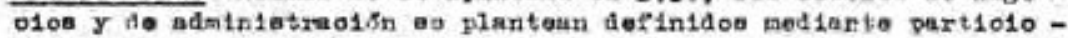
nea liviansa que permiten roplda inataladion $y$ mudir:scasón de ubi

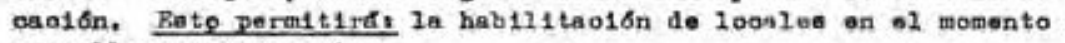
que allo mea neosarto, ta remoción para otrs atillonaion de la muperfio1e.

3.9. - Creolm1ento - Diado el Blatema construot1vo modular de la ostaolón, Gata pueda roalizarse por atapa que respondan a la solloltación surgidntiel oaudal de trifnesto to los oolvotivos, oon la 16 gios 11- 


\section{Concurso para la Terminal de Ómnibus de Resistencia, Chaco}

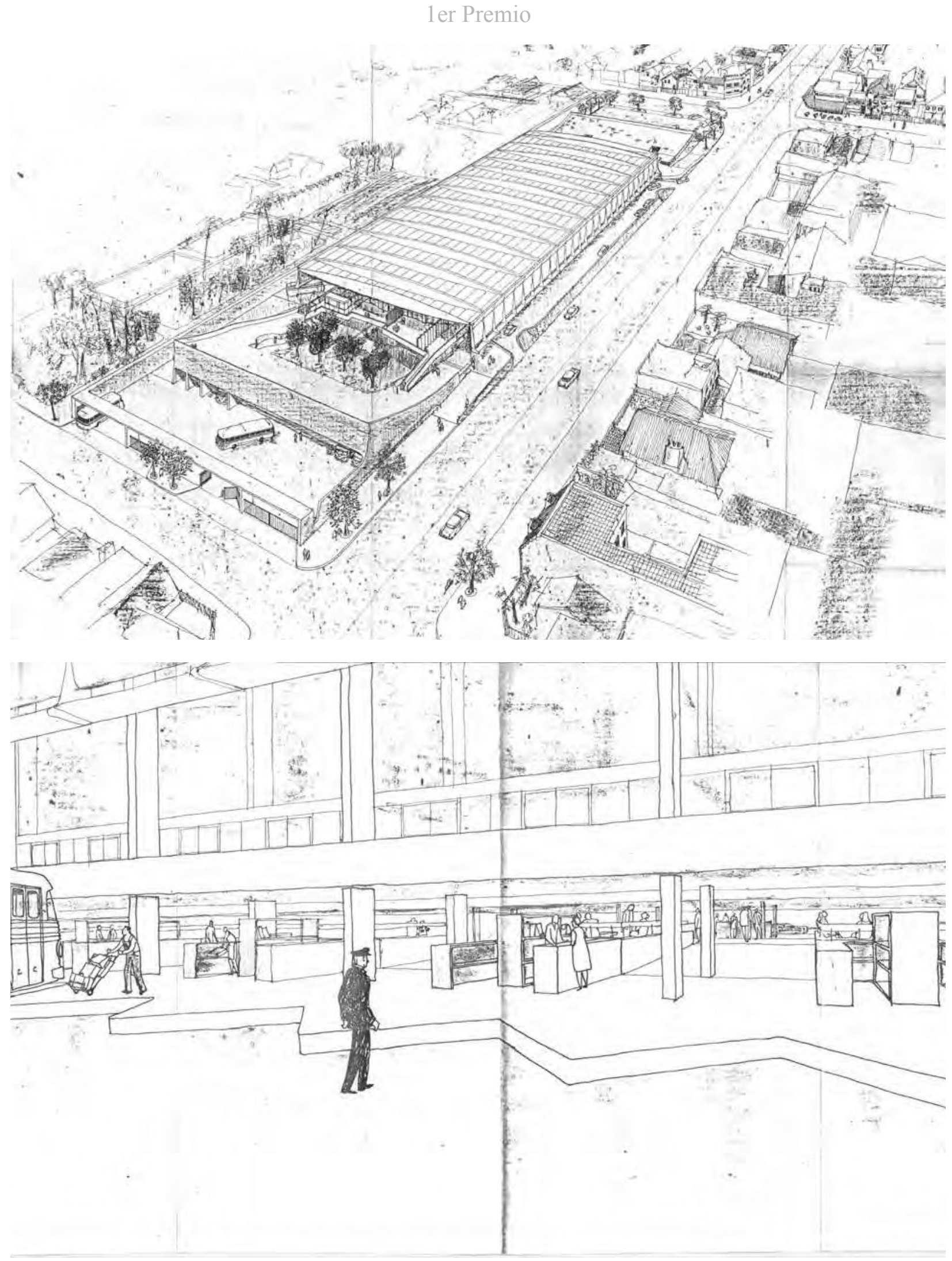

$172-173$ 

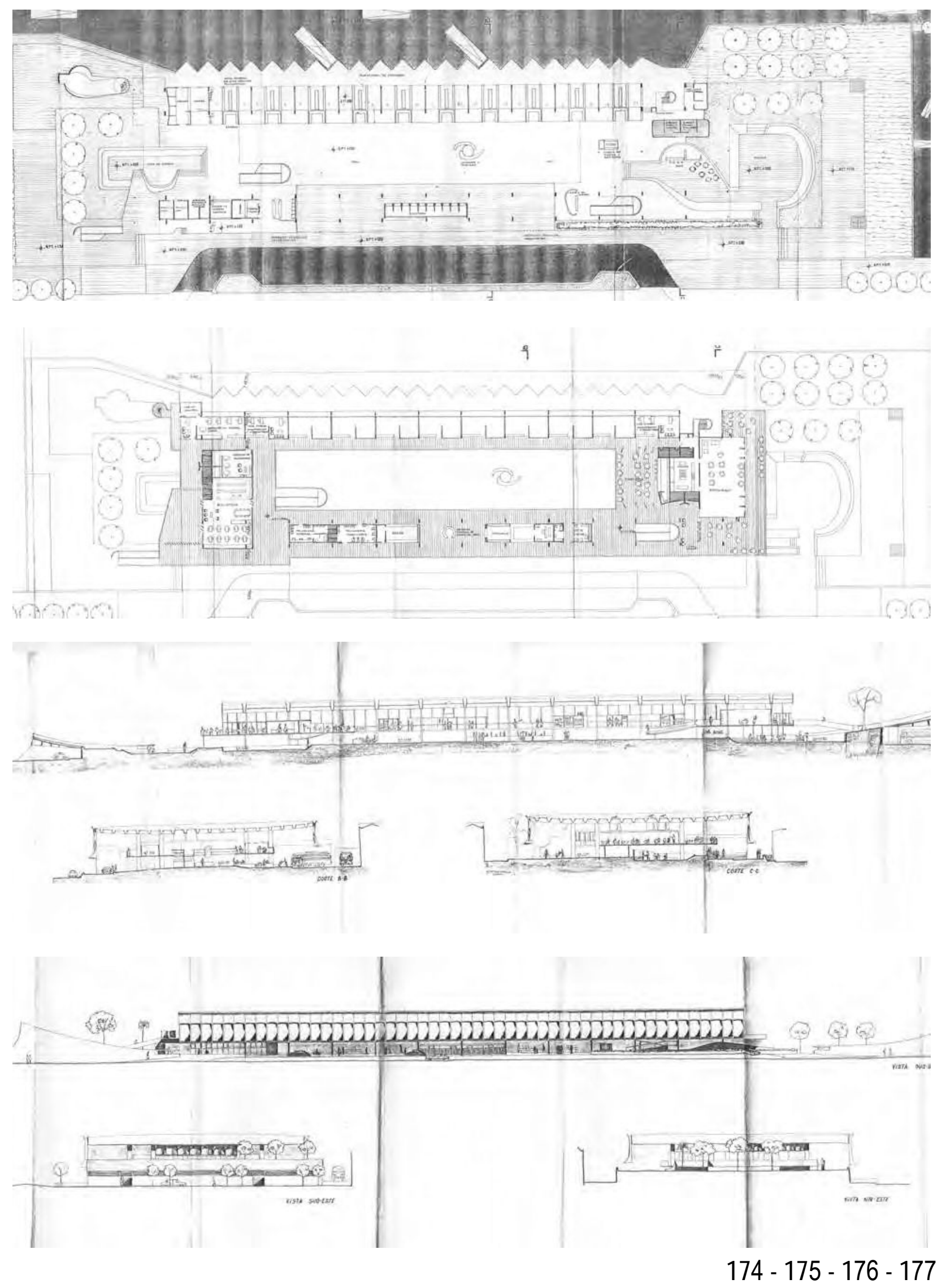

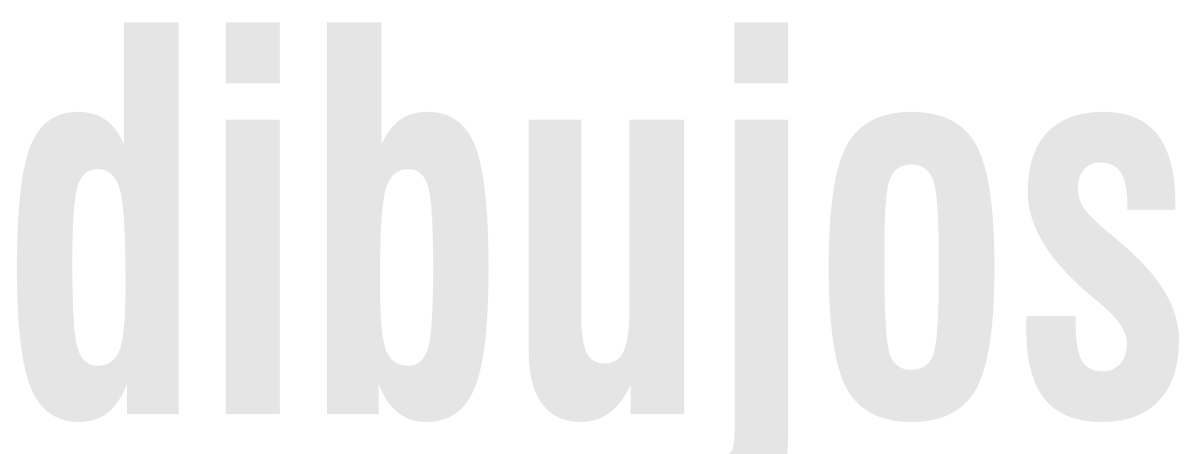

SERIE DE DIBUJOS REALIZADOS POR MARIO SOTO, CONCURSO DE AMSTERDAM Y HOSPITAL ESCUELA DE CÓRDOBA

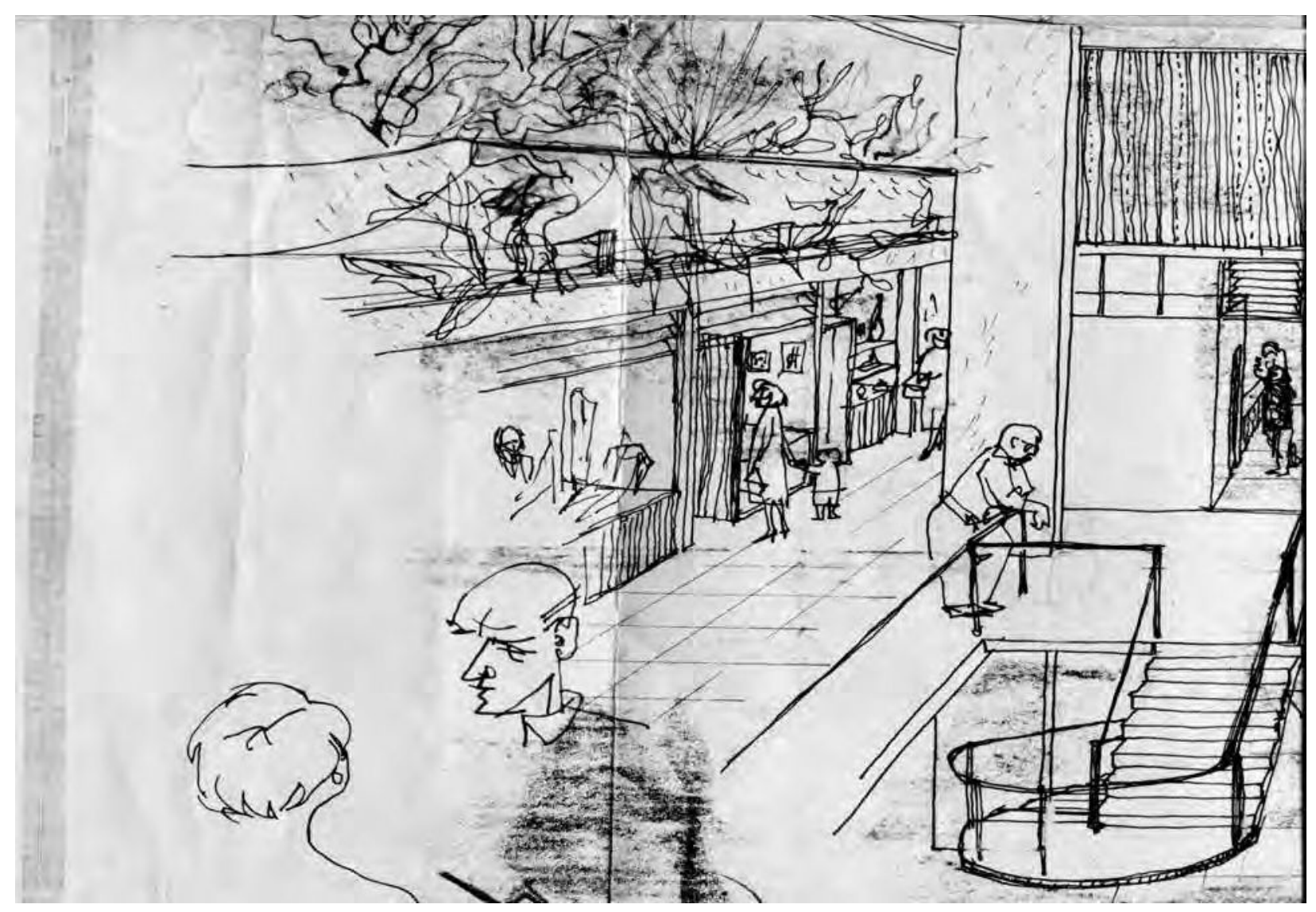


Dibujos y bocetos realizados por Mario Soto (en sus "corbusiómetros")
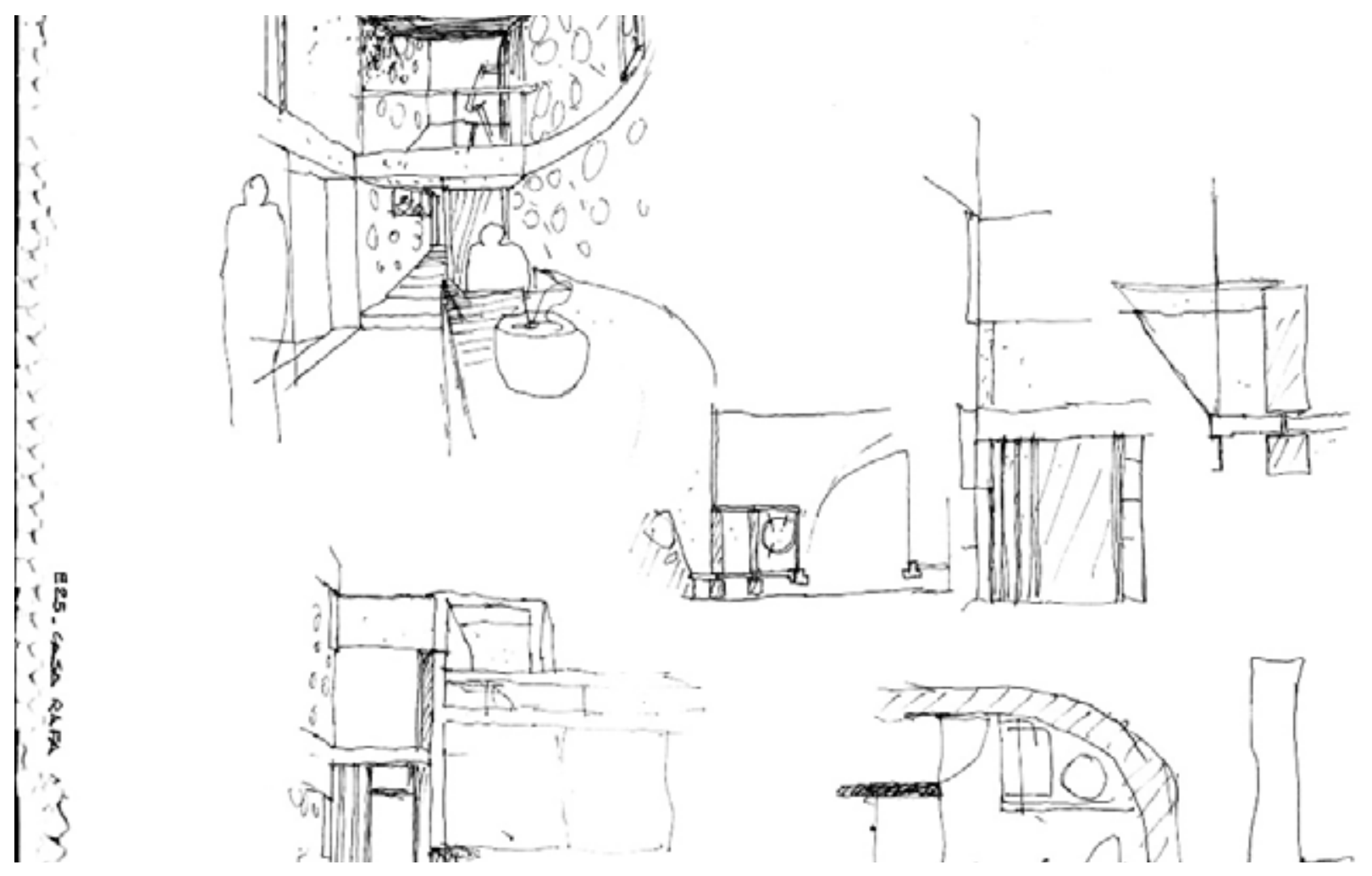

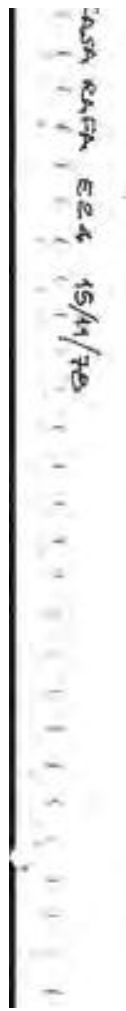

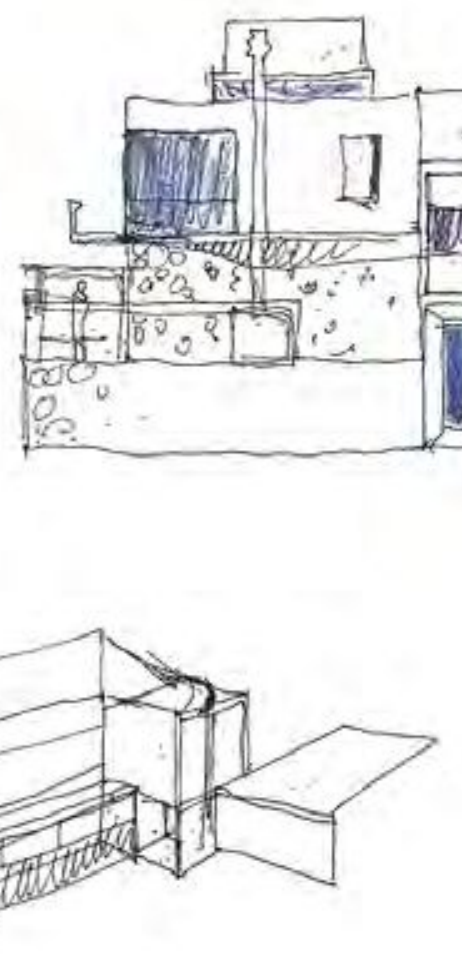

$178-179$ 
Dibujos y bocetos realizados por Mario Soto

Analizando casas de España
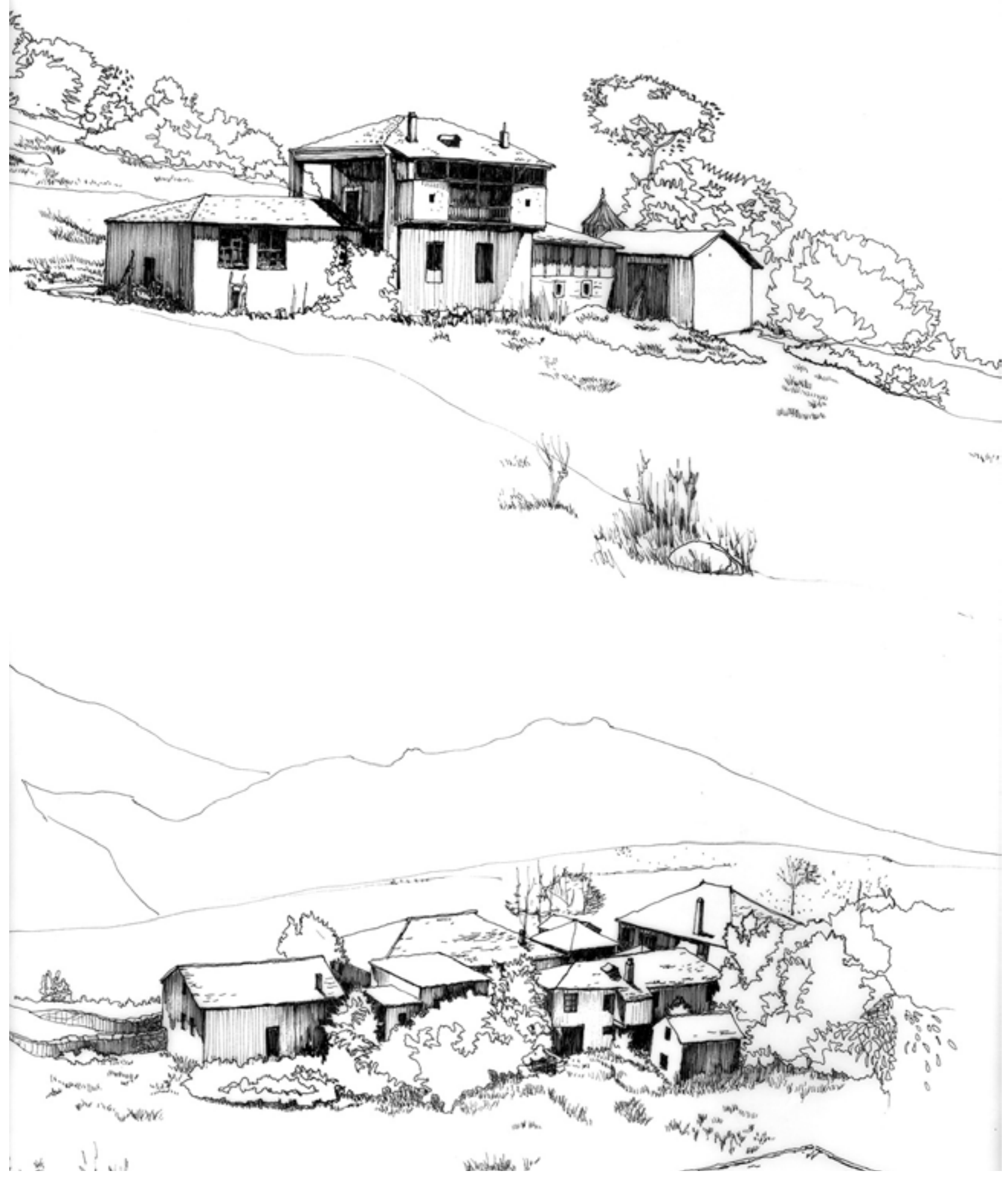

$180-181$ 
Dibujos y bocetos realizados por Mario Soto

Estudios del interior de una vivienda unifamiliar en Pontevedra Edificio de Control, Autopista del Atlántico, España (1976)
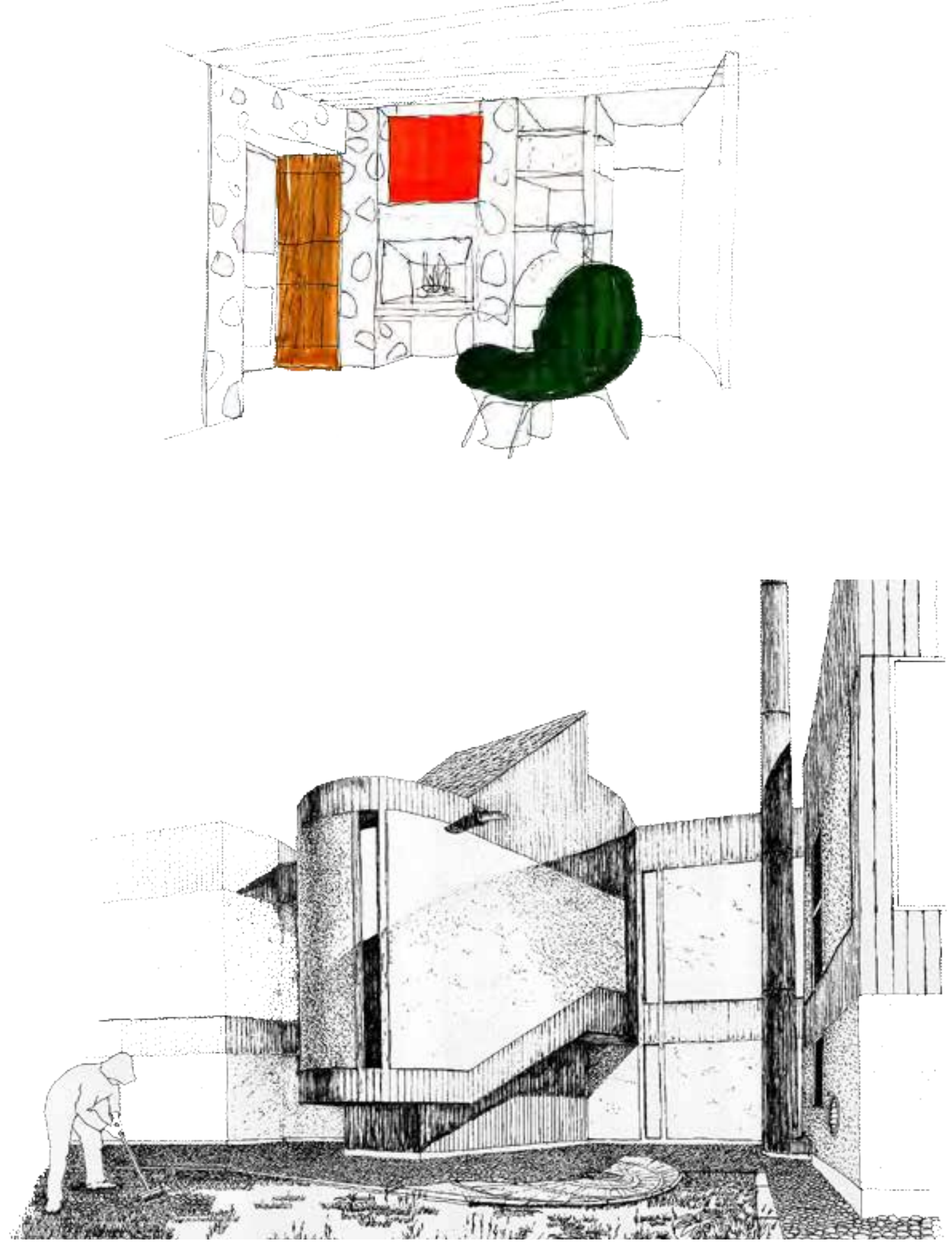

$182-183$ 
Dibujos y bocetos realizados por Mario Soto (en sus "corbusiómetros")

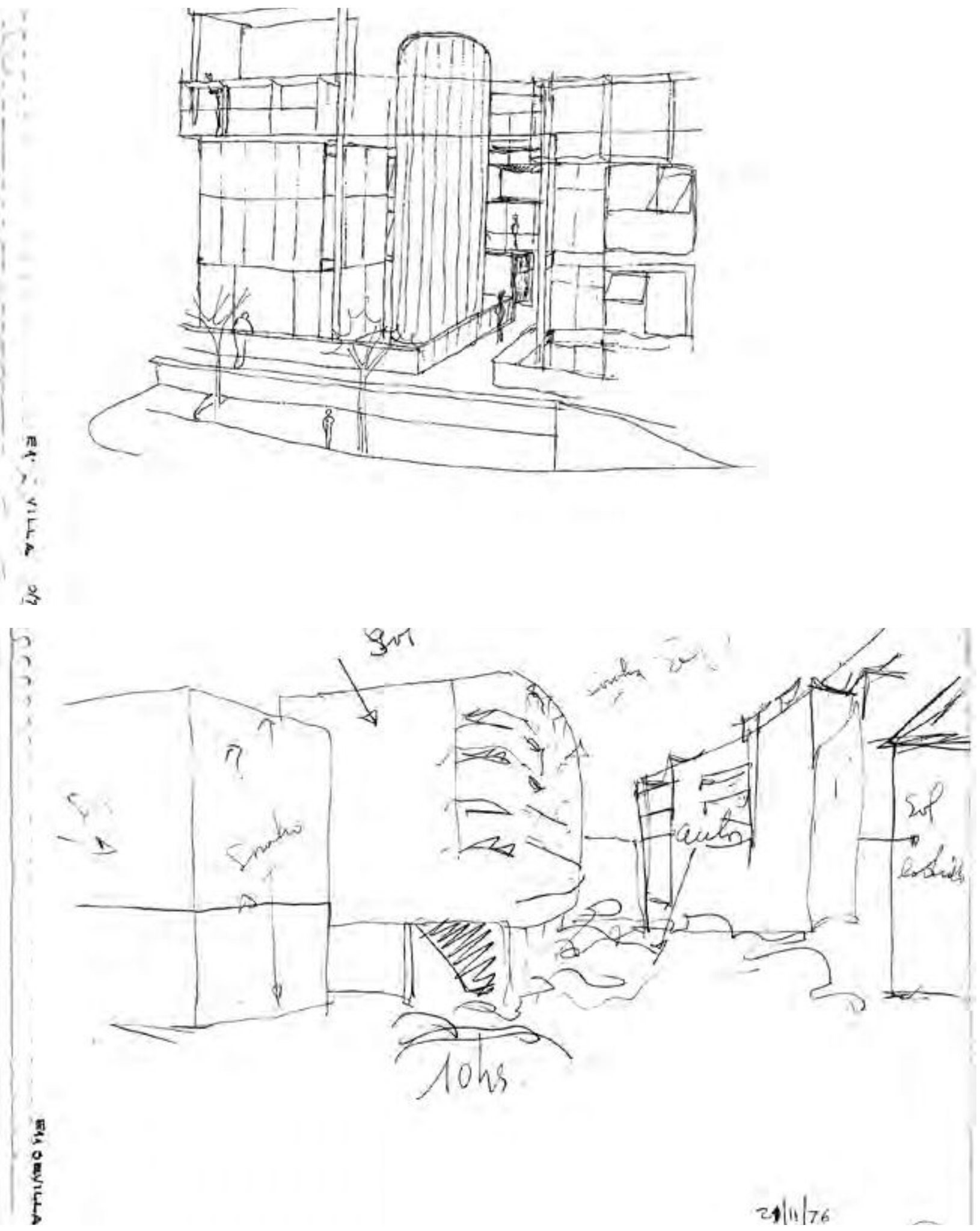

$184-185$ 


\section{Dibujos y bocetos realizados por Mario Soto}

Esquemas y perspectivas para el Concurso del Ayuntamiento de Amsterdam
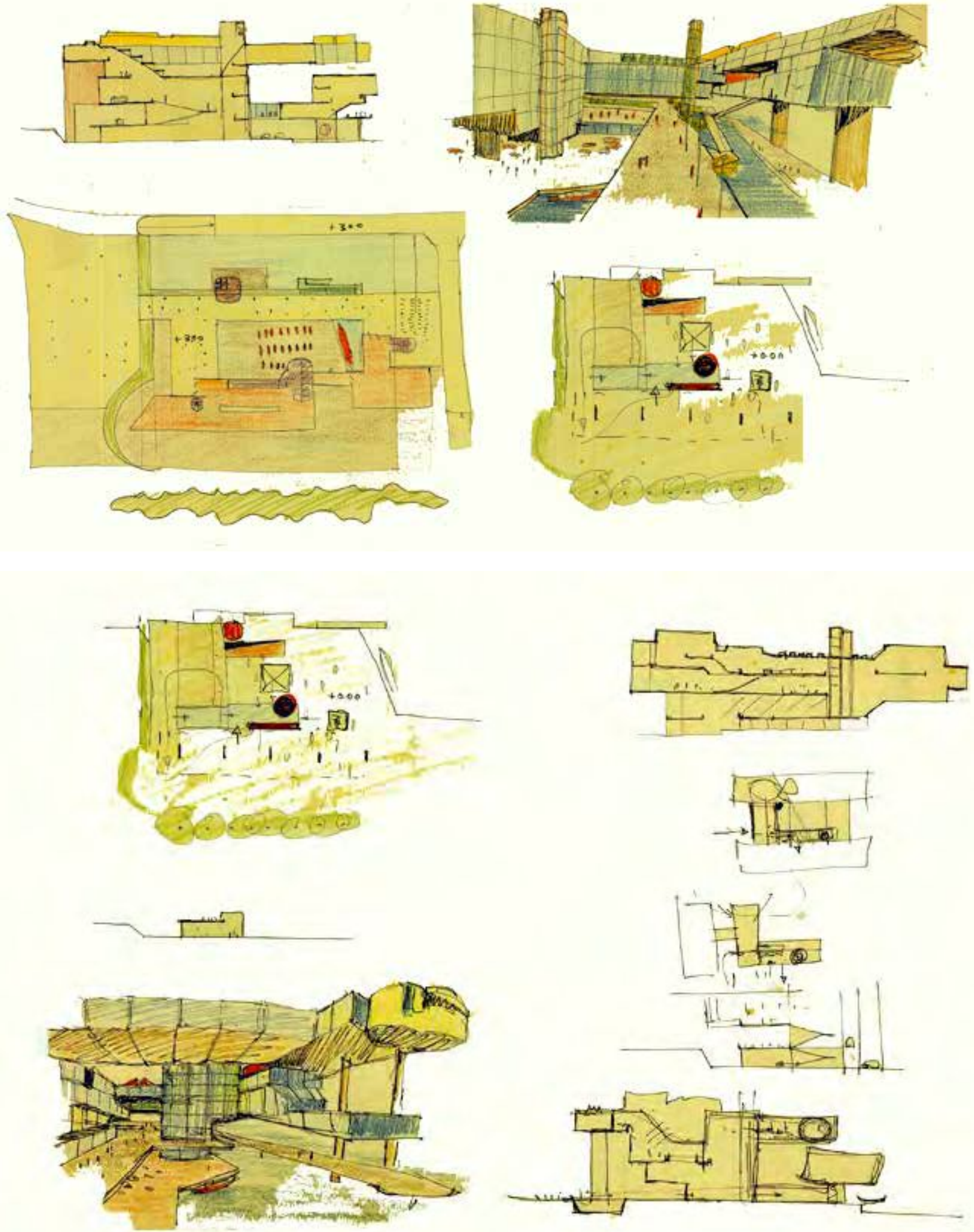

$186-187$ 
Concurso del Hospital Escuela Universitario, Córdoba

Fachada y Corte del IPS. Posadas
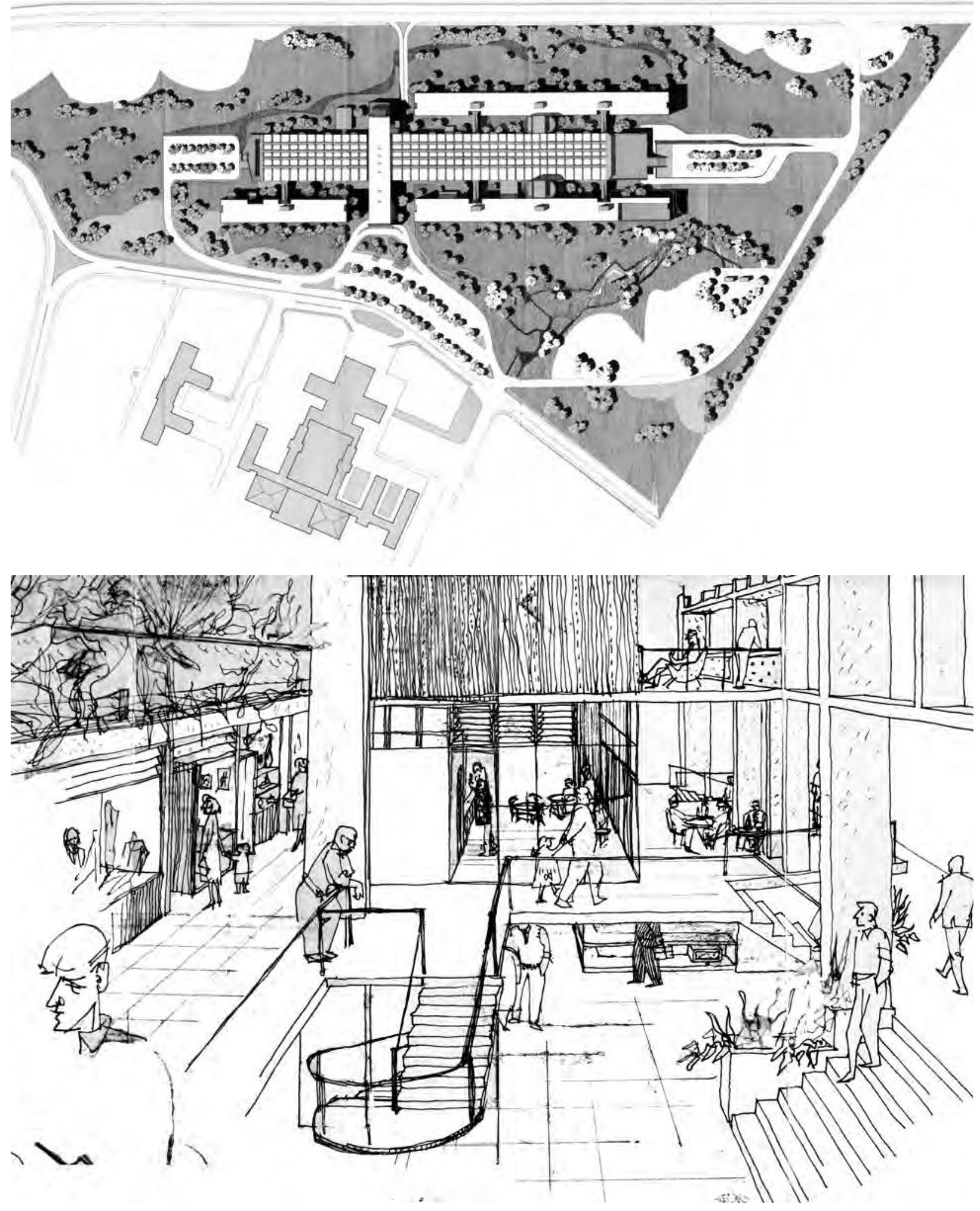

$188-189$ 

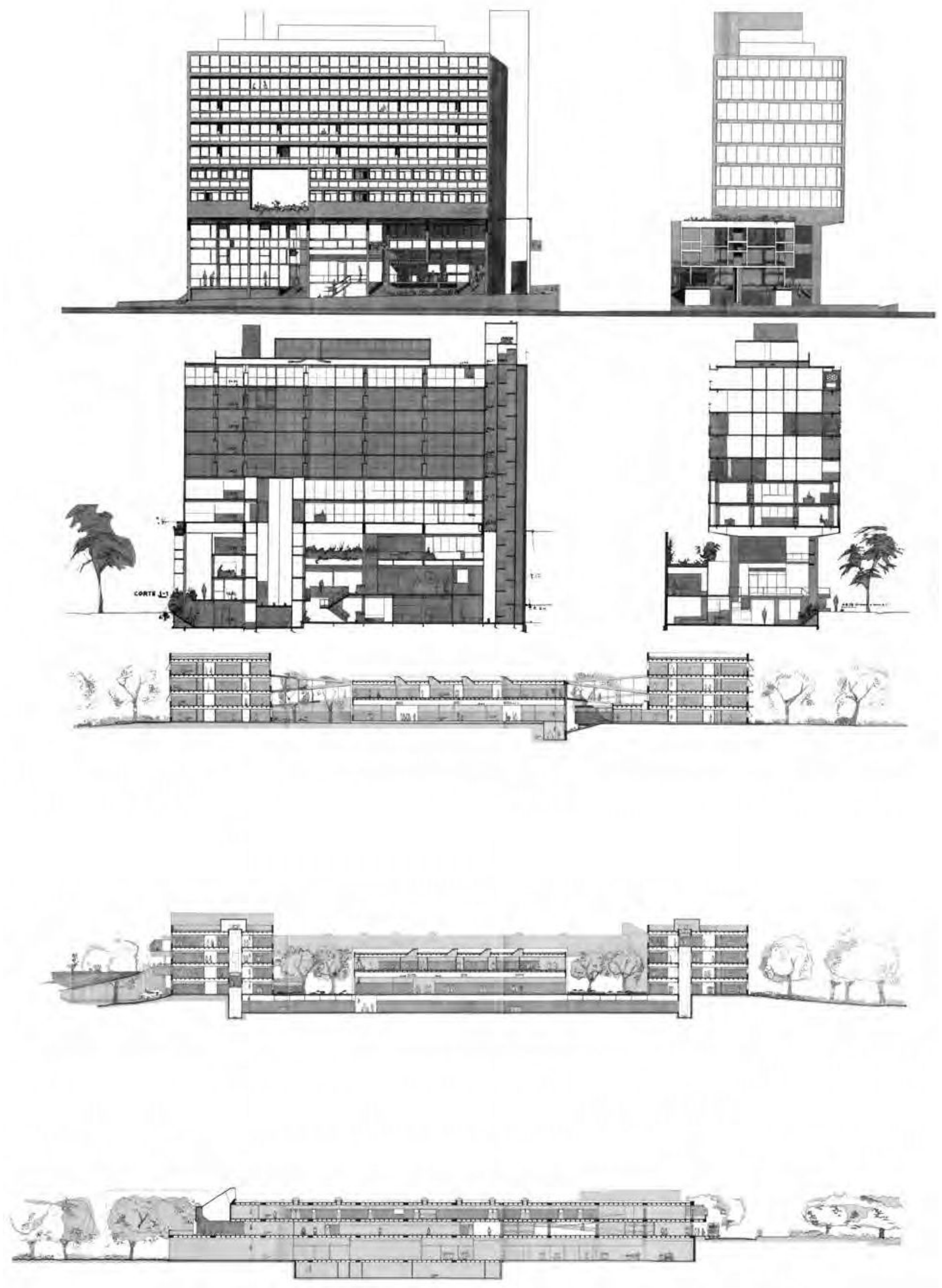

$190-191-192-193$ 
Libros utilizados como información y referencia durante el concurso de las escuelas de madera

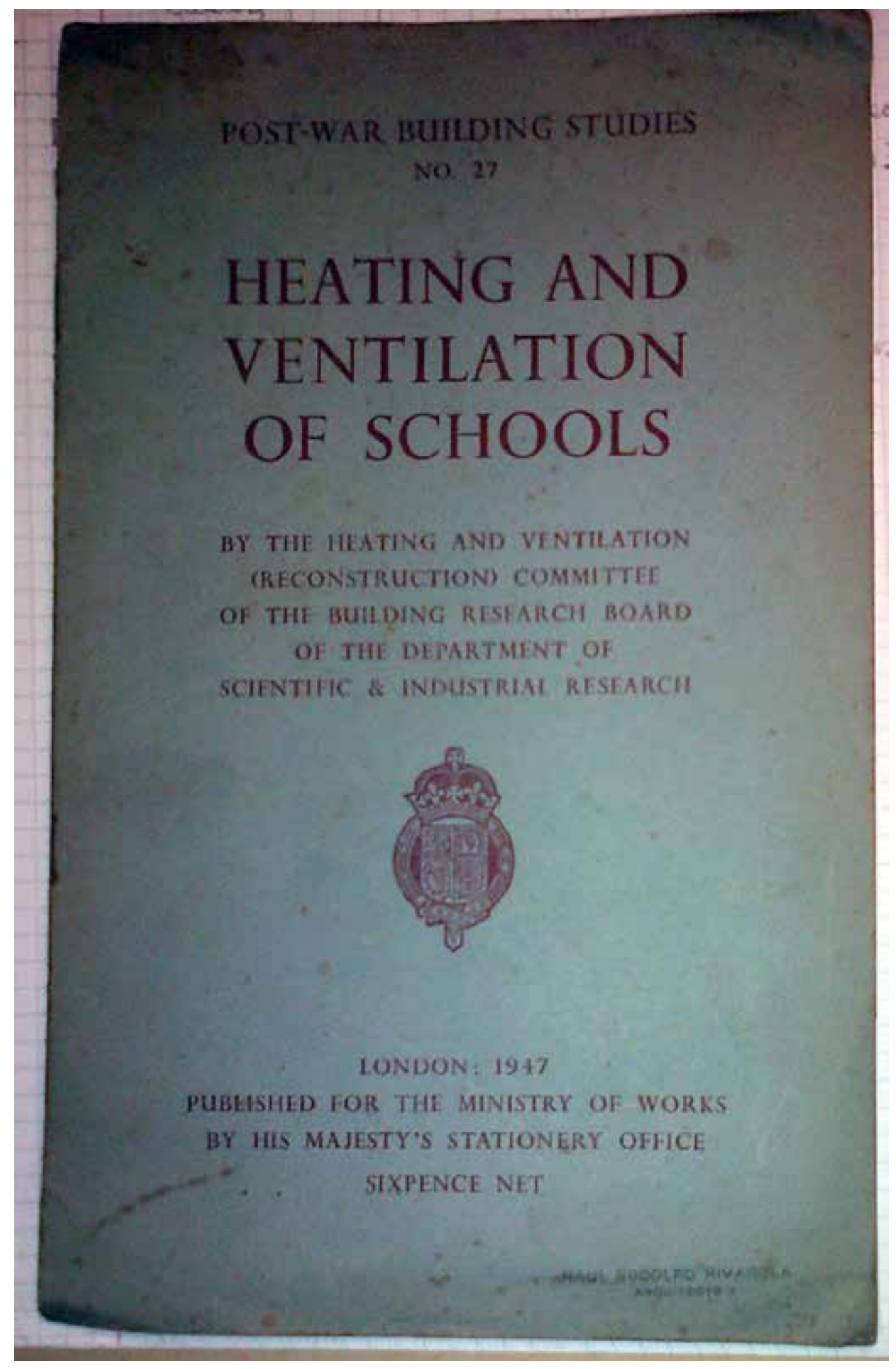


Libros utilizados como información y referencia durante el concurso de las escuelas de madera

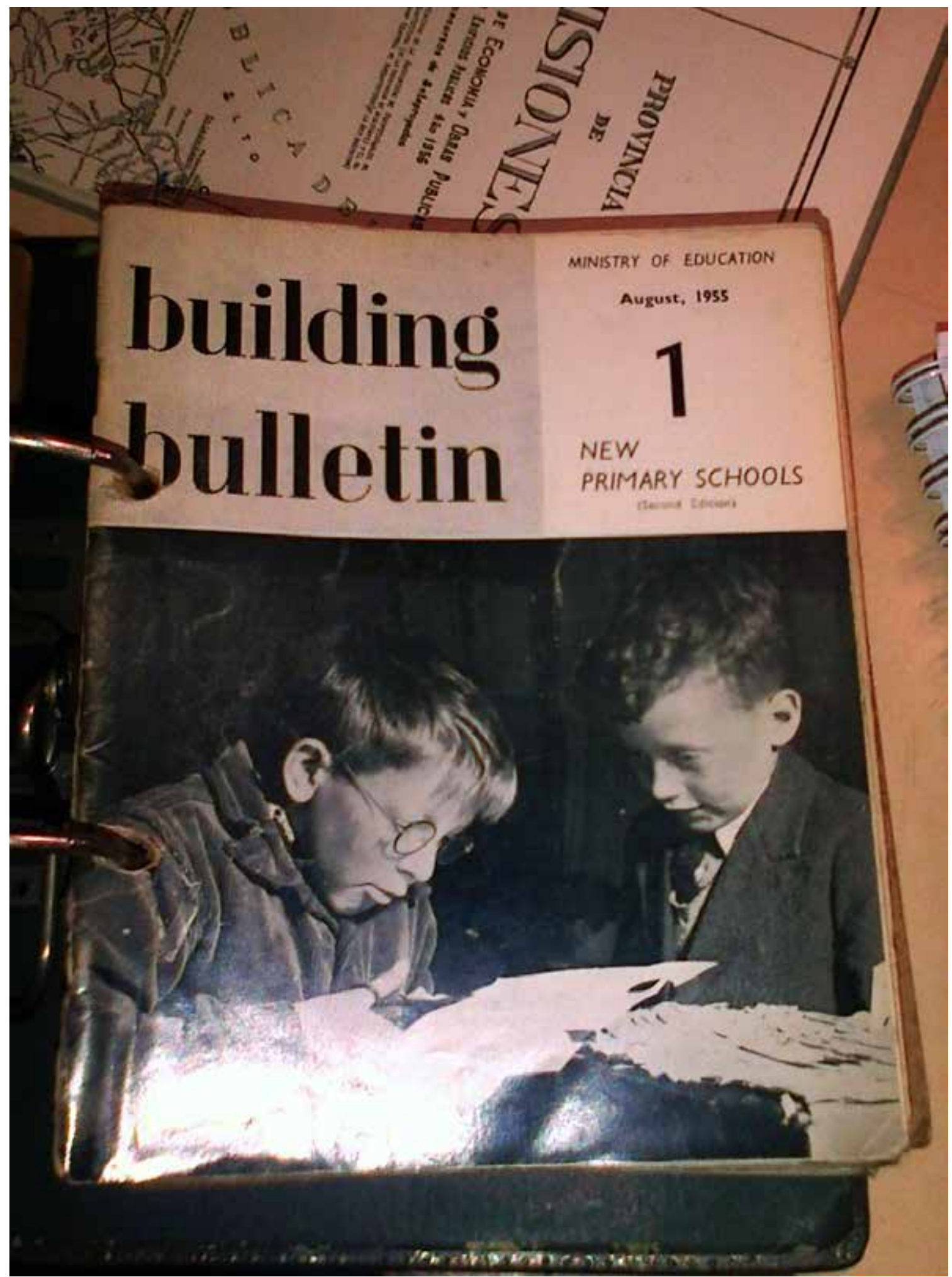


Libros utilizados como información y referencia durante el concurso de las escuelas de madera

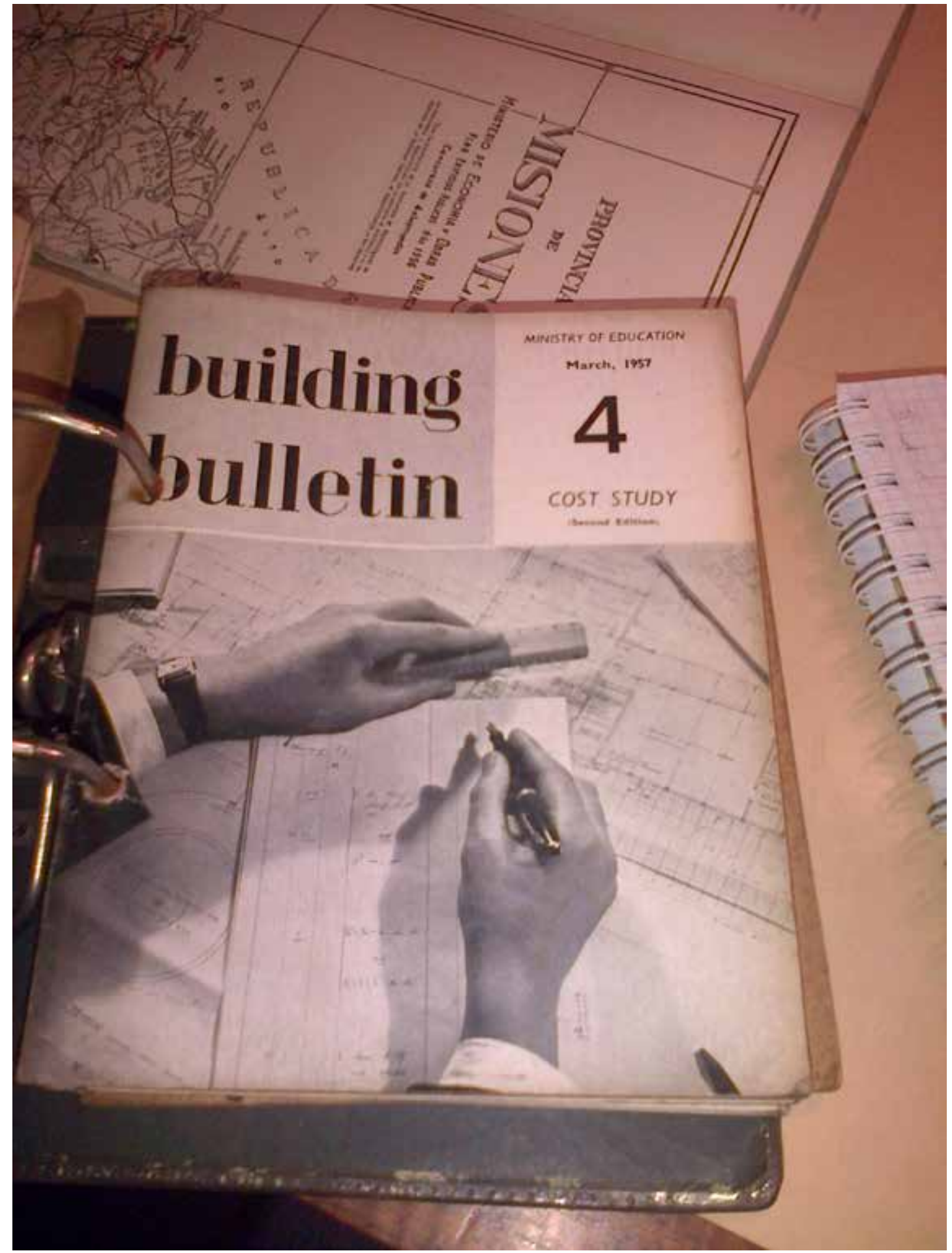


Libros utilizados como información y referencia durante el concurso de las escuelas de madera

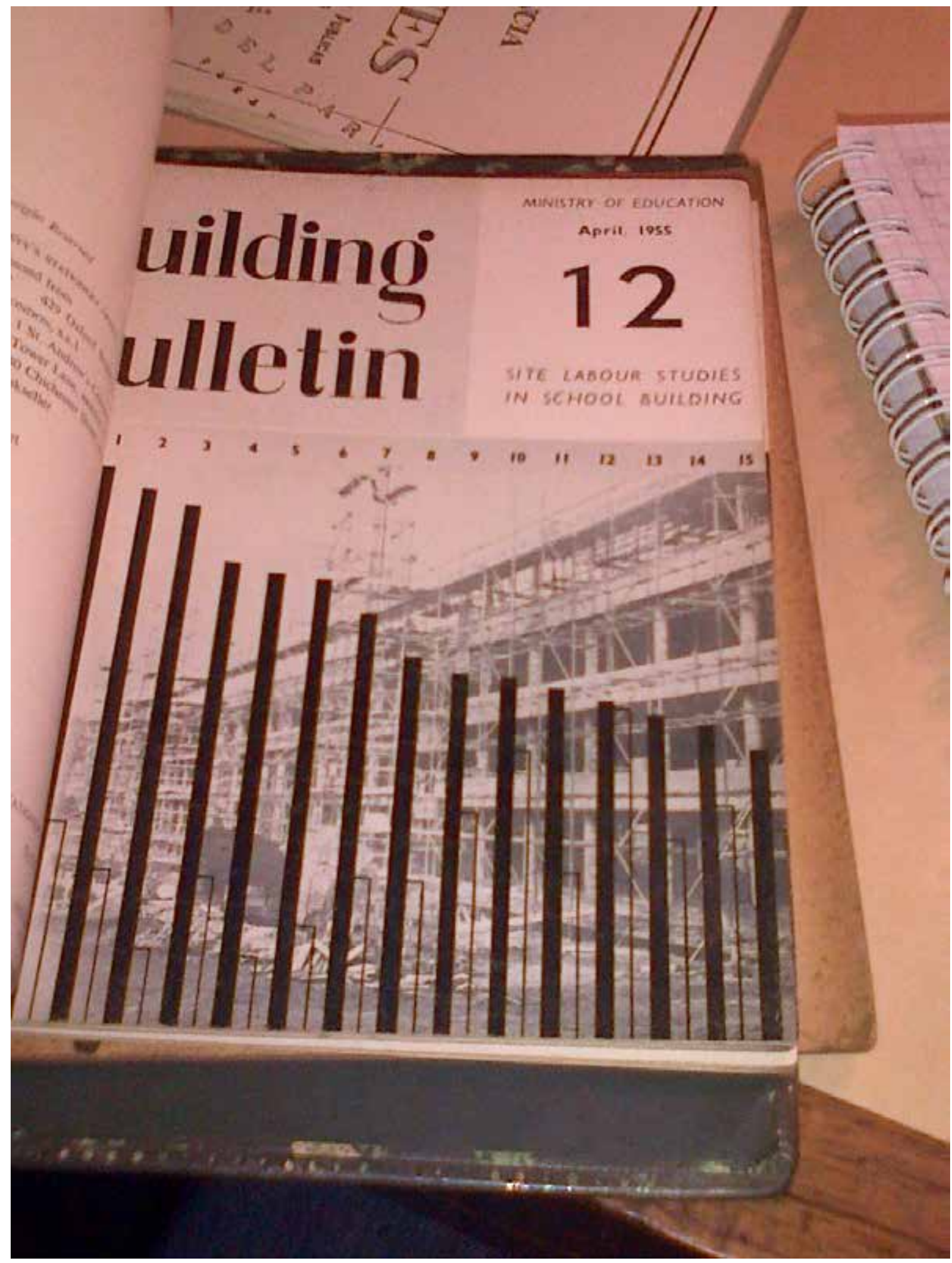

